\title{
BIOLOGICAL ACTIVITY OF ESSENTIAL OILS FROM LEAVES AND FRUITS OF PEPPER TREE (Schinus molle L.) TO CONTROL RICE WEEVIL (Sitophilus oryzae L.)
}

\author{
Verónica Benzi ${ }^{1}$, Natalia Stefanazzi ${ }^{1}$, and Adriana A. Ferrero ${ }^{*}$
}

\begin{abstract}
Rice weevil (Sitophilus oryzae L.) is a primary insect pest of stored grain. The development of resistance resulted in the application of synthetic insecticides. In recent years many plant essential oils have provided potential alternatives to currently used insect control agents. The Brazilian pepper tree (Schinus molle L. var. areira (L.) DC.) (Anacardiaceae) has different biological properties such as insecticidal activity. In this study, repellent, fumigant activity, nutritional indices, and feeding deterrent action were evaluated on S. oryzae adults. Filter paper impregnation was used to test fumigant toxicity, whereas treated whole wheat was used to evaluate repellent activity and a flour disk bioassay was done to evaluate feeding deterrent action and nutritional index alteration. Leaf essential oils showed repellent effects at both concentrations ( 0.04 and $0.4 \% \mathrm{w} / \mathrm{w})$, while fruit essential oils lacked repellent activity. Both plant oils altered nutritional indices. Fruit essential oils had a strong feeding deterrent action (62\%) while leaves had a slight effect (40.6\%). With respect to fumigant activity, neither of the essential oils was found to be toxic.
\end{abstract}

Key words: Schinus molle, Sitophilus oryzae, repellency, fumigant toxicity, nutritional indices, feeding deterrence.

\section{INTRODUCTION}

Harvest grains are basic human food products (Padín et al., 2002). The presence of pests constitutes a serious on-going problem in stocking grains and its derived industry (Pérez Mendoza et al., 2004).

Worldwide, between 5 and $15 \%$ of the total weight of cereals, oil plants, and legumes are lost after harvesting (Anonymous, 1989), and between 5 and $10 \%$ of these losses are due to the presence of pests (Hill, 1990). In Argentina, the losses caused by insects and/or mites are estimated between 7 and 10\% of total production (Viale, 1995). The legislation of this country establishes the rejection of any merchandise with a single insect and/or live mite in any commercialization stage (Resolution $\mathrm{N}^{\circ}$ 1975/94, Secretaría de Agricultura, Ganadería y Pesca).

The rice weevil (Sitophilus oryzae L.) is one of the pests of primary infestation of stored grains, widely spread worldwide, and very destructive. Because of its high incidence, synthetic insecticides have been used to control it.

${ }^{1}$ Universidad Nacional del Sur, Departamento de Biología, Bioquímica y Farmacia, San Juan 670 (8000), Bahía Blanca, Argentina.

*Corresponding author (aferrero@uns.edu.ar).

Received: 14 April 2008.

Accepted: 16 June 2008.
Resistance and toxicity problems of the synthetic insecticides have resulted in the necessity of finding more effective and healthier alternatives. Thus, essential oils are the most tested products presently (Papachristos and Stamopoulus, 2002; Umoetok and Gerard, 2003; Zhang et al., 2004; Tapondjou et al., 2005; Ferrero et al., 2006; Sánchez Chopa et al., 2006, Stefanazzi et al., 2006, Wang et al., 2006). Different biological activities of plant derivatives have been demonstrated for the control of stored grain pests (Golob et al., 1999; Rajendran and Sriranjini, 2008).

The Brazilian pepper tree (Schinus molle L. var. areira (L.) DC.) is associated with agricultural crops in boundaries, windbreaks, riverbank protection, and watershed conservation. In popular medicine, it is use for its astringent, diuretic, antispasmodic properties among others. In pest control, it is used as a fumigant, repellent, and ovicide (Ruffínengo et al., 2005; Ferrero et al., 2006).

The objective of the present study was to evaluate the fumigant, repellent and/or attractant, feeding deterrent activity, and the alterations in the nutritional physiology produced by the essential oils from leaves and fruits of $S$. molle var. areira on 3- to 4-day-old $S$. oryzae adults. 


\section{MATERIALS AND METHODS}

\section{Insects}

The insects came from a susceptible colony maintained in the Cátedra de Zoología Agrícola de la Universidad Nacional de Buenos Aires (UBA). They were bred in glass containers, $8 \mathrm{~cm}$ in diameter, $13 \mathrm{~cm}$ high, sealed with fine netting, maintained at $28 \pm 1{ }^{\circ} \mathrm{C}, 60-70 \% \mathrm{HR}$, a $12: 12$ photoperiod, and using whole wheat grains as food.

\section{Vegetal material}

The vegetal organs (leaves and mature fruits) of the pepper tree were collected during the summer period in Bahía Blanca city, Buenos Aires, Argentina (3841’ S; $62^{\circ} 17^{\prime}$ W). A specimen was deposited in the Herbarium of the Departamento de Biología, Bioquímica y Farmacia de la Universidad Nacional del Sur (BBB) and identified as number CV 10444. The essential oils were isolated using fresh vegetal material by accelerated distillation of water vapor using a Clevenger-type device during 3 to 4 $\mathrm{h}$, and were analyzed with gas chromatography and mass spectrometry (GC-MS HP5972A) in a HP5 (30 m x 0.25 $\mathrm{mm}$ ) column with a temperature program of $50{ }^{\circ} \mathrm{C}$ during $2 \mathrm{~min}$, a $5{ }^{\circ} \mathrm{C} \mathrm{min}^{-1} \mathrm{ramp}$, and a final temperature of 200 ${ }^{\circ} \mathrm{C}$ during $15 \mathrm{~min}$. The composition of the oils from both vegetal organs can be observed in Table 1 . Oil yield was $0.22 \%$ and $0.42 \%(\mathrm{w} / \mathrm{v})$ for leaves and fruits, respectively. The yield was calculated using fresh vegetal material.

\section{Bioassays}

Repellent activity of the essential oils from leaves and fruits of $S$. molle var. areira on $S$. oryzae adults. An experimental field made of a central box connected by cylinders to four boxes symmetrically distributed around the first was used. Two boxes received $2 \mathrm{~g}$ of whole wheat treated with $2 \mathrm{~mL}$ of hexanic oil solutions at 0.04 and $0.4 \%$ $(\mathrm{w} / \mathrm{v})$, and $2 \mathrm{~g}$ rations impregnated with $2 \mathrm{~mL}$ of hexane were put in the remaining boxes as controls. In the central box, 40 unsexed 3 to 4 days old adults were released. After $24 \mathrm{~h}$, the preference index (PI) was calculated using the Equation [1].

$$
\begin{aligned}
\mathrm{PI}= & \text { (percentage of insects in treated ration) }- \\
& \text { (percentage of insects in non-treated ration) } \\
& \text { (percentage of insects in treated ration) }+ \\
& \text { (percentage of insects in non-treated ration) }
\end{aligned}
$$

where PI: -1.00 to -0.10 indicates repellent plant, PI: -0.10 to +0.10 neutral plant, and PI: +0.10 to +1.00 attractant plant. Furthermore, the repellency percentage was calculated based on the number of insects found in the control at the end of $24 \mathrm{~h}$ (Procopio et al., 2003). Three

\begin{tabular}{|c|c|c|}
\hline Compound & Leaves & Fruits \\
\hline & & \\
\hline Limonene & 15.68 & 40.34 \\
\hline$\alpha$-Phellandrene & 13.80 & 24.47 \\
\hline Elemol & 9.00 & \\
\hline$\beta$-Cubebene & 7.30 & \\
\hline Camphene & 5.31 & 1.19 \\
\hline$\delta$-Cadinene & 5.26 & \\
\hline$\gamma$-Eudesmol & 3.61 & \\
\hline$\alpha$-Pinene & 3.56 & 2.96 \\
\hline$\beta$-Eudesmol & 2.80 & \\
\hline$\beta$-Pinene & 2.13 & 0.58 \\
\hline$\beta$-Myrcene & 1.72 & 16.35 \\
\hline Sabinene & 1.48 & \\
\hline Caryophyllene & 1.36 & 1.61 \\
\hline Triciclene & 0.82 & \\
\hline Bornyl acetate & 0.82 & \\
\hline 1-Terpinen-4-ol & & 3.34 \\
\hline$\beta$-Phellandrene & & 2.39 \\
\hline 3-Carene & & 1.35 \\
\hline Methyl octanoate & & 1.32 \\
\hline 2-Carene & & 0.47 \\
\hline$\alpha$-Humulene & & 0.25 \\
\hline Copaene & & 0.10 \\
\hline
\end{tabular}
replicates were carried out.
Table 1. Essential oil constituents from leaves and fruits of Schinus molle var. areira.

Nutritional indices and antifeeding activity of the essential oils from leaves and fruits of $S$. molle on $S$. oryzae adults. To evaluate the antifeeding activity and the alteration in the nutritional physiology in adults, $1.6 \mathrm{~cm}$ diameter disks of wheat flour were prepared (Huang et al., 2002). Aliquots of $200 \mu \mathrm{L}$ from a flour suspension in water (10 g in $50 \mathrm{~mL}$ ) were put on plastic dishes to form the disks and were left all night to dry in a chamber at 25 ${ }^{\circ} \mathrm{C}$ temperature and 60 to $70 \%$ relative humidity (Dalvo, model MCI/2 V.c.a 220, Argentina). The disks were weighed registering values between 70 to $78 \mathrm{mg}$. Hexanic solutions of the oils were prepared at concentrations of $0,0.5,1,2$, and $4 \mathrm{mg} \mathrm{disk}^{-1}$. Two disks of wheat flour were impregnated with $5 \mu \mathrm{L}$ of these solutions, weighed, and put in separated containers. A control group with hexane treated disks was prepared. Ten 3- to 4-daysold adult insects previously weighed on a scale (FX/FY series FX400, Frankfurt, Germany) were put into each container. After maintaining them during $72 \mathrm{~h}$ in controlled conditions, the weight of the disks, mortality, and weight of insects alive were registered. Six replicates were carried out. Each assay was repeated independently at least three times. The nutritional indices were calculated: 
Relative growth rate $(\mathrm{RGR})=(\mathrm{A}-\mathrm{B}) /(\mathrm{B} \mathrm{x}$ day $)$, where $\mathrm{A}=$ weight of insects alive on the third day/number of insects alive on the third day; $\mathrm{B}$ = original weight of insects/ total number of insects; relative consumption rate (RCR) which indicates the consumption of the insects related to their initial weight and the duration of the assay RCR = $\mathrm{D} /(\mathrm{B} \times$ day), where $\mathrm{D}=$ biomass ingested (mg)/number of insects alive on the third day; efficiency of conversion of ingested food (ECI) (\%) that indicates the quantity of food used for weight gain in the insects, $E C I=(R G R / R C R) x$ 100. To obtain the antifeeding effect (AE), EA (\%) $=[(\mathrm{C}-$ $\mathrm{T}) / \mathrm{C}] \times 100$ was calculated where $\mathrm{C}=$ consumption of control disks (mg) and $\mathrm{T}=$ consumption of treated disks (mg) (Farrar et al., 1989).

Fumigant activity of the essential oils from leaves and fruits of $S$. molle var. areira on $S$. oryzae adults. Filter papers, $7 \mathrm{~cm}$ in diameter, were impregnated with 1 $\mathrm{mL}$ of hexanic solutions of the essential oils from leaves and fruits at concentrations of 10, 20, 40, and $80 \mathrm{mg} \mathrm{L}^{-1}$. Hexane was used as a control. The solvent was left to evaporate during $5 \mathrm{~min}$. The treated filter paper was put at the bottom of a $350 \mathrm{~mL}$ glass jar. Ten insects were put in each small glass tube of $5 \mathrm{~cm}$ high and $3 \mathrm{~cm}$ in diameter, with whole wheat and both open ends, covered with a fine netting to avoid them to scape. Each vial was suspended with a metal thread in the geometrical center of the jar which was hermetically sealed with a cover. The assay was carried out at controlled temperature and relative humidity conditions $\left(28 \pm 1^{\circ} \mathrm{C}, 60-70 \% \mathrm{RH}\right)$, and a 12:12 photoperiod. Three replicates were done. Each experiment was repeated independently at least three times. The percentage of mortality was evaluated after 72 $h$ and expressed in $\mathrm{mg} \mathrm{L}^{-1}$ of air.

\section{Statistical analysis of data}

The data were analyzed by simple ANOVA test, completely randomized design prior normalization with $(\sqrt{ } \mathrm{x}+1)^{1 / 2}$, using the replicates corresponding to each assay, and the means were separated using the minimum significant differences test with Microsoft Excel (MST, $\mathrm{p} \leq$ 0.05) (Zar, 1999).

\section{RESULTS}

Repellent activity of the essential oils from leaves and fruits of $S$. molle var. areira on $S$. oryzae adults. The repellent and/or attractant effects produced by the essential oils of S. molle on S. oryzae adults can be observed in Table 2.

It can be inferred from the analysis of Table 2 that the oil from leaves at both concentrations produced a repellent effect. However, the oil from fruits at the highest concentration produced an attractant effect whereas the lowest did not show any.
Table 2. Repellent activity of essential oil from leaves and fruits of the Brazilian pepper tree (Schinus molle var. areira) on adults rice weevils (Sitophilus oryzae).

\begin{tabular}{lccc}
\hline Oil & Concentration & Repellency & PI \\
\hline \multirow{4}{*}{ Leaf } & $\% \mathrm{p} / \mathrm{v}$ & $\%$ & \\
& 0.04 & 65.00 & -0.30 \\
\multirow{2}{*}{ Fruit } & 0.40 & 71.47 & -0.40 \\
& 0.04 & 50.03 & -0.01 \\
& 0.40 & 49.73 & 0.50 \\
\hline
\end{tabular}

PI: Preference index: -1.0 to -0.1 repellent plant; -0.1 to +0.1 neutral plant, and +0.1 to +1.0 attractant plant.

Nutritional indices and antifeeding activity. In Tables 3 and 4, the results corresponding to the effects produced by both oils in relation to the nutritional indices and the antifeeding activity on S. oryzae adults are shown.

The oil from fruits modified the nutritional indices. RGR decreased in all the concentrations and highly significant differences were observed $(\mathrm{p} \leq 0.01)(\mathrm{F}: 11.34$, df: 20). Differences in RCR between the concentrations 0.5 , 2, and $4 \mathrm{mg}$ disk $^{-1}$ were observed with respect to the control ( $p \leq 0.01)$ (F: 6.2987, df: 20). ECI was only affected (at the highest) concentration ( $\mathrm{p} \leq 0.01$ ) (F: 6.6128, df: 20). A $54 \%$ mortality rate was observed at $4 \mathrm{mg}$ disk $^{-1}$ concentration. AE $(\mathrm{P}=0.1)(\mathrm{F}: 2.2587$, df: 16) of the oil from fruits of $S$. molle was slight at lower concentrations whereas it was high in the maximum concentration. Values greater than $51 \%$ were considered to be high.

The oil from leaves modified the nutritional indices, but contrary to what occurred with the oil from fruits, AE was slight ( $p=0.07)(F: 2.733$, df: 16). Furthermore, high significant differences were found $(\mathrm{p} \leq 0.01)$ ( $\mathrm{F}$ : 4.3679, df: 20) in RGR at concentrations 1, 2, and $4 \mathrm{mg}$ disk $^{-1}$ respect to the control. RCR decreased at maximum concentration respect to the control, and dropped off significantly at minimum concentration $(\mathrm{p} \leq 0.05)$ (F: 3.1604, df: 20). The same situation was observed with ECI $(\mathrm{p} \leq 0.05)$ (F: 3.3773, df: 20). A high mortality percentage was obtained with the essential oils from leaves at the highest concentration.

Fumigant activity of the essential oils from leaves and fruits of $S$. molle var. areira on 3- to 4-days-old $S$. oryzae adults. No fumigant toxicity was observed at the evaluated concentrations.

\section{DISCUSSION}

In this study, the essential oil of the leaves showed a repellent effect in both concentrations with repellency rates of 65 and $71.5 \%$ in the 0.04 and $0.4 \%$ concentrations, 
Table 3. Nutritional indices and feeding deterrent activity of essential oil from fruits of Brazilian pepper tree (Schinus molle var. areira) on adults rice weevils (Sitophilus oryzae).

\begin{tabular}{|c|c|c|c|c|c|}
\hline Concentration & RGR & RCR & ECI & Mortality & $\mathbf{A E}$ \\
\hline mg disk ${ }^{-1}$ & 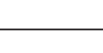 & 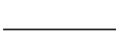 & & - \% & 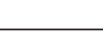 \\
\hline 0 & $0.02 \mathrm{c}$ & $0.28 c$ & $7.61 \mathrm{~b}$ & $2 b$ & 0 \\
\hline 0.5 & $-0.07 b$ & $0.17 \mathrm{ab}$ & $-47.12 b$ & $18 \mathrm{~b}$ & $30.68 a$ \\
\hline 1 & $-0.06 b$ & $0.2 \mathrm{bc}$ & $-71.96 b$ & $14 \mathrm{~b}$ & 20.11a \\
\hline 2 & $-0.08 b$ & $0.18 b$ & $-51.11 b$ & $14 \mathrm{~b}$ & $28.75 a$ \\
\hline 4 & $-0.20 \mathrm{a}$ & $0.09 a$ & $-312.2 \mathrm{a}$ & $54 a$ & $62.07 \mathrm{a}$ \\
\hline
\end{tabular}

RGR: relative growth rate. RCR: relative consumption rate. ECI: efficiency conversion of ingested food. AE: antifeeding effect. Different letters in the same column indicate significant differences $(\mathrm{p} \leq 0.05$ ) between treatments according to ANOVA and minimum significant difference (MSD).

Table 4. Nutritional indices and feeding deterrent activity of essential oil from leaves of Brazilian pepper tree (Schinus molle var. areira) on adults rice weevils (Sitophilus oryzae).

\begin{tabular}{|c|c|c|c|c|c|}
\hline Concentration & RGR & RCR & ECI & Mortality & $\mathbf{A E}$ \\
\hline mg disk ${ }^{-1}$ & - & $\longrightarrow$ & & - \% & \\
\hline 0 & $0.05 c$ & $0.3 \mathrm{~b}$ & $17.63 c$ & $2 b$ & 0 \\
\hline 0.5 & $-0.009 b c$ & $0.28 b$ & $-8.86 b c$ & $12 b$ & $-9.84 a$ \\
\hline 1 & $-0.08 a b$ & $0.22 \mathrm{ab}$ & $-60.7 a b c$ & $36 a$ & $18.36 a$ \\
\hline 2 & $-0.1 \mathrm{ab}$ & $0.2 \mathrm{ab}$ & $-69.87 a b$ & $36 a$ & $24.63 a$ \\
\hline 4 & $-0.14 a$ & $0.16 \mathrm{a}$ & $-111.34 \mathrm{a}$ & $58 a$ & $40.60 a$ \\
\hline
\end{tabular}

RGR: relative growth rate. RCR: relative consumption rate. ECI: efficiency of conversion of ingested food. AE: antifeeding effect. Different letters in the same column indicate significant differences $(\mathrm{p} \leq 0.05)$ between treatments according to ANOVA and minimum significant difference (MSD).

respectively. Using essential oil from the leaves of Artemisia princeps Pamp. (Asteraceae), Liu et al. (2006) observed a good repellent activity on $S$. oryzae. On the other hand, Amelot et al. (2003) demonstrated that oils of Ageratum conyzoides L. (Asteraceae) leaves did not produce a repellent effect on this insect. The oil from fruits of $S$. molle var. areira resulted attractant only at the highest concentration. The observed differences in the effects produced by the essential oils could be due to the presence of different secondary metabolites in both vegetal organs (Murray et al., 2005).

The AE of the oil from leaves of $S$. molle was slight, whereas with fruits it was high. Valera et al. (2003) found that the essential oil of Coleus amboinicus Loureiro (Lamiaceae) was not able to induce any response in the feeding behavior of $S$. oryzae at high doses (1.25\%), there was not mortality during the $60 \mathrm{~h}$ of bioassay exposition.

Oils from leaves and fruits of $S$. molle modified the nutritional physiology of $S$. oryzae, altering RGR, RCR, and ECI. The oil from fruits, at maximum dose $(4 \mathrm{mg}$ disk $^{-1}$ ) produced high mortality which could be due to an inhibition in the feeding behavior (behavioral effect) based on the decrease of the RCR and the high antifeeding effect. The oil from leaves at maximum concentration also produced high mortality as a consequence of a possible postingestion toxicity due to the slight $\mathrm{AE}$ and the decrease in ECI. Liu and Ho (1999) observed modifications in RGR, but neither in the consumption rate, nor in ECI with Evodia rutaecarpa (Rutaceae) in another Sitophilus species. The essential oil of Tagetes ternifolia (Asteraceae) also produced postingestion toxicity in other pest of stored grains Tribolium castaneum (Stefanazzi et al., 2006).

The essential oils from leaves and fruits of $S$. molle did not produce fumigant activity on $S$. oryzae adults. The lack of this activity could be due to the fact that the entrance of these compounds is through the cuticle, to the need of higher concentrations to reach the mortality, or more exposition time. A similar situation was observed by Pascual Villalobos et al. (2004) using essential oils from leaves of Ocimum basilicum L. (Lamiaceae). Authors such as Negahban et al. (2007), Negahban and Moharramipour (2007) demonstrated fumigant activity with essential oils of Artemisia (Asteraceae) and Eucalyptus (Mirtacea) species on S. oryzae. In Sitophilus granarius, oils of Salvia hydrangea DC., former Benth (Lamiaceae) produced toxicity (Kotan et al., 2008).

\section{CONCLUSIONS}

This study demonstrated that the essential oil from leaves of Schinus molle var. areira produced repellency 
on $S$. oryzae, while the fruit resulted attractant at $0.4 \%$, and neutral at a concentration of $0.04 \%$. Both oils altered nutritional physiology, showed antifeeding activity, and did not exhibit fumigant activity.

For all these reasons, we can infer that the essential oils of leaves and fruits of Schinus molle var. areira could be considered as a natural alternative in the control of $S$. oryzae.

\section{ACKNOWLEDGEMENTS}

Our thanks to the Secretaría de Ciencia y Tecnología (SECyT) de la Universidad Nacional del Sur, Bahía Blanca, Provincia de Buenos Aires, Argentina (PGI: 24/B109), to the Agencia de Promoción Científica y Tecnológica (ANCYT-PICTO-BID 1728/ OC-ARPICT $\mathrm{N}^{\circ}$ 925) for the subsidies granted, to the Consejo Nacional de Investigaciones Científicas y Técnicas (CONICET) for its scholar Verónica Soledad Benzi.

\section{RESUMEN}

Bioactividad de aceites esenciales de hojas y frutos del aguaribay (Schinus molle L.) en el gorgojo del arroz (Sitophilus oryzae L.). El gorgojo del arroz (Sitophilus oryzae. L.) es un insecto-plaga de infestación primaria de granos. El uso de insecticidas sintéticos ha desarrollado fenómenos de resistencia. En los últimos años los aceites esenciales se presentan como una alternativa en el control de insectos-plaga. El aguaribay (Schinus molle L. var. areira (L.) DC.) (Anacardiaceae) es una planta con diferentes propiedades biológicas entre las que se destacan el uso como insecticida. El objetivo de este estudio fue evaluar la actividad fumigante, repelente, los índices nutricionales y la actividad antialimentaria de los aceites esenciales de hojas y frutos de S. molle var. areira en adultos de $S$. oryzae. Para la actividad fumigante se utilizó la técnica de impregnación de papeles de filtro; para la actividad repelente impregnación de trigo entero; y para los índices nutricionales y la actividad antialimentaria impregnación de discos de harina de trigo. El aceite esencial de hojas mostró efectos repelentes a ambas concentraciones $(0,04$ y $0,4 \% \mathrm{p} / \mathrm{v})$, mientras que el de frutos no produjo repelencia. Ambos aceites alteraron la fisiología nutricional de $S$. oryzae. El aceite de frutos produjo un efecto antialimentario fuerte (62\%) y el de hojas leve (40,6\%). No se observó actividad fumigante.

Palabras clave: Schinus molle, Sitophilus oryzae, repelencia, toxicidad fumigante, índices nutricionales, efecto antialimentario.

\section{LITERATURE CITED}

Amelot, A., M.E., M. Avendaño, y L. Aubert. 2003. Repelencia e inhibición alimentaria causada por Ageratum conyzoides sobre los insectos-plaga de granos almacenados Tribolium castaneum y Sitophilus oryzae. Partes activas de la planta y su composición. Ciencia 11:61-76.

Anonymous. 1989. Proceeding of the $18^{\text {th }}$ International Course on Plant Protection. International Agricultural Centre, Wageningen, The Netherlands.

Farrar Jr., R.R., J.D. Barbour, and G.G. Kennedy. 1989. Quantifying food consumption and growth in insects. Ann. Entomol. Soc. Am. 82:593-598.

Ferrero, A.A., J.O. Werdin González, and C. Sánchez Chopa. 2006. Biological activity of Schinus molle on Triatoma infestans. Fitoterapia 77:381-383.

Golob, P., C. Moss, M. Dales, A. Fidgen, J. Evans, and I. Gudrups. 1999. The use of spices and medicinals as bioactive protectants for grains. FAO Agric. Serv. Bull. $N^{\circ}$ 137. p. 221-236. FAO, Rome, Italy.

Hill, D.S. 1990. Pests of stored products and their control. 274 p. CRC Press, Boca Ratón, Florida, USA.

Huang, Y., S.H. Ho, H.C. Lee, and Y.L. Yap. 2002. Insecticidal properties of eugenol, isoeugenol and their effects on nutrition of Sitophilus zeamais Motsch. (Coleoptera: Curculionidae) and Tribolium castaneum (Herbst) (Coleoptera: Tenebrionidae). J. Stored Prod. Res. 38:403-412.

Kotan, R., S. Kordali, A. Cakir, M. Kesdek, Y. Kaya, and H. Kilic. 2008. Antimicrobial and insecticidal activities of essential oil isolated from Turkish Salvia hydrangea DC. ex Benth. Biochem. Syst. Ecol. 36:360-368.

Liu, Z.L., and S.H. Ho. 1999. Bioactivity of the essential oil from Evodia rutaecarpa Hook F. et Thomas against the grain storage insects, Sitophilus zeamais Motsch. and Tribolium castaneum (Herbst). J. Stored Prod. Res. 35:317-328.

Liu, C.H., A.K. Mishra, R.X. Tan, C. Tang, H. Yang, and Y.F. Shen. 2006. Repellent and insecticidal activities of essential oils from Artemisia princeps and Innamomum camphora and their effect on seed germination of wheat and broad bean. Bioresour. Technol. 97:1969-1973.

Murray, A.P., M.A. Frontera, M.A. Tomas, and M.C. Mullet. 2005. Gas chromatography-mass spectrometry study of the essential oil of Schinus longifolia (Lindl.) Speg., Schinus fasciculate (Griseb.) I. M. Johnst., and Schinus areira L. Z. Naturforsch., C: Biosci. 60:2529. 
Negahban, M., S. Moharramipour, and F. Sefidkon. 2007. Fumigant toxicity of essencial oil from Artemisia sieberi Besser against three stored-product insects. J. Stored Prod. Res. 43:123-128.

Negahban, M., and S. Moharramipour. 2007. Fumigant toxicity of Eucalyptus intertexta, Eucalyptus sargentii and Eucalyptus camaldulensis against stored-product beetles. J. Appl. Entomol. 131:256-261.

Padín, S., G. Dal Bello, and M. Fabricio. 2002. Grain loss caused by Tribolium castaneum, Sitophilus oryzae and Acanthoscelides obtectus in stored durum wheat and beans treated with Beauveria bassiana. J. Stored Prod. Res. 38:69-74.

Papachristos, D.P., and D.C. Stamopoulos. 2002. Toxicity of vapours of three essential oils to the immature stages of Acanthoscelides obtectus (Say) (Coleoptera: Bruchidae). J. Stored Prod. Res. 38:365-373.

Pascual Villalobos, M.J., M.C. Ballesta Acosta, y A. Soler. 2004. Toxicidad y repelencia de aceites esenciales en plagas de almacén del arroz. Bol. San. Veg. Plagas 30:279-286.

Pérez Mendoza, J., P.W. Flinn, J.F. Campbell, D.W. Hagstrum, and J.E. Throne. 2004. Detection of storedgrain insect infestation in wheat transported in railroad hopper-cars. J. Econ. Entomol. 97:1474-1483.

Procopio, S., J. Vendramin, J. Ribeiro, e J. Santos. 2003. Bioactibidade de iversos pós de origen vegetal em relaçáo a Sitophilus zeamais Mots (Coleoptera: Curculionidae). Ciencia Agrotecnica 27:1231-1236.

Rajendran, S., and V. Sriranjini. 2008. Plant products as fumigant for stored-product insect control. J. Stored Prod. Res. 44:126-135.

Ruffinengo, S., M. Eguaras, I. Floris, C. Faverin, P. Bailac, and M. Ponzi. 2005. LD50 and repellent effects of essential oils from Argentinean wild plant species on Varroa destructor. J. Econ. Entomol. 98:651-655.

Sánchez Chopa, C., R. Alzogaray, and A. Ferrero. 2006. Repellency of Schinus molle var. areira (Anacardiaceae) essential oils to the German cockroach (Blattodea: Blattellidae). Bioassay 1:6.
Secretaría de Agricultura \& Ganadería. 1994. Boletín Oficial $\mathrm{N}^{\mathrm{o}}$ 28.043. 80 p. Dic. 21. $1^{\mathrm{a}}$ Sección. Secretaría de Agricultura \& Ganadería, Buenos Aires, Argentina.

Stefanazzi, N., M.M. Gutiérrez, T. Stadler, N.A. Bonini, y A.A. Ferrero. 2006. Actividad biológica del aceite esencial de Tapetes terniflora Kunth (Asteraceae) en Tribolium castaneum Herbst (Insecta, Coleoptera, Tenebrionidae). Bol. Sanid. Veg. Plagas 32:439-447.

Tapondjou, A.L., C. Adler, D.A. Fontem, H. Bouda, and C. Reichmuth. 2005. Bioactivities of cymol and essencial oils of Cupressus sempervirens and Eucalyptus saligna against Sitophilus zeamais Motschulsky and Tribolium confusum du val. J. Stored Prod. Res. 41:91-102.

Umoetok, S.B.A., and M.B. Gerard. 2003. Comparative efficacy of Acorus calamus powder and two synthetic insecticides for control of three major insect pests of stored cereal grains. Global J. Agric. Sci. 2:94-97.

Valera, D., R. Rivas, J.L. Ávila, L. Aubert, M. Alonso Amelot, y A. Usubillaga. 2003. El aceite esencial de Coleus amboinicus Loureiro. Composición química y evaluación de sus efectos antialimentarios en insectos. Ciencia 11:113-118.

Viale, J.A. 1995. Conservación de granos en silos-chacra. 10 p. Instituto Nacional de Tecnología Agropecuaria (INTA), Estación Experimental Agropecuaria Marcos Juárez, Córdoba, Argentina.

Wang, J., F. Zhu, X.M. Zhou, C.Y. Niu, and C.L. Lei. 2006. Repellent and fumigant activity of essential oils from Artemisia vulgaris to Tribolium castaneum (Herbst) (Coleoptera: Tenebrionidae). J. Stored Prod. Res. 42:339-347.

Zar, J.H. 1999. Biostatistical analysis. $4^{\text {th }}$ ed. 663 p. Prentice Hall, New Jersey, USA.

Zhang, M.X., B. Ling, S.Y. Chen, G.W. Liang, and X.F. Pang. 2004. Repellent and oviposition deterrent activities of the essential oil from Mikania micrantha and its compounds on Plutella xylostella. Entomol. Sinica 11:37-45. 


\title{
LIFE TABLE PARAMETERS AND CONSUMPTION RATE OF Cydnodromus picanus Ragusa, Amblyseius graminis Chant, AND Galendromus occidentalis (Nesbitt) ON AVOCADO RED MITE Oligonychus yothersi (McGregor) (ACARI: PHYTOSEIIDAE, TETRANYCHIDAE)
}

\author{
Tommy Rioja S..$^{*}$, and Robinson Vargas M. ${ }^{2}$
}

\begin{abstract}
The avocado red mite Oligonychus yothersi (McGregor) is the major leaf pest in Chile's avocado orchards. It affects leaf physiology and makes it necessary to seek new natural enemies to interact with low population densities of $O$. yothersi. The potentiality of three predator mites: Cydnodromus picanus Ragusa, Amblyseius graminis Chant, and Galendromus occidentalis (Nesbitt) was evaluated under laboratory conditions $\left(27 \pm 1.93{ }^{\circ} \mathrm{C}, 87 \pm 3.61 \%\right.$ H.R. and 16:8 (L:D) photoperiod) on avocado leaf disks Persea americana Mill. var. Hass ( $\varnothing=5 \mathrm{~cm})$ by separately feeding eggs, immature, and adult females of $O$. yothersi, and registering postembryonic development, consumption, as well as life table parameters. The postembryonic development of $C$. picanus was significantly lower (5.46 days) compared to both A. graminis (7.33 days) and G. occidentalis (8.69 days) which were fed with immature O. yothersi. The life table parameters of $C$. picanus were net reproductive rate $\mathrm{R}_{0}=25.41$, finite rate of increase $\lambda=1.29$, and mean generation time $\mathrm{T}=12.46$. The net intrinsic rate of increase $\left(\mathrm{r}_{\mathrm{m}}\right)$ was significantly higher for $C$. picanus $\left(\mathrm{r}_{\mathrm{m}}=\right.$ 0.25 ) in contrast with $G$. occidentalis $\left(r_{m}=0.19\right)$, while A. graminis showed $r_{m}=-0.06$ indicating that its population didn't have descendants. Under laboratory conditions, $\mathrm{r}_{\mathrm{m}}$ registered by $C$. picanus is an indicator of its predatory potential to control $O$. yothersi. It can be assumed that the pest population reduction pattern could be maintained under field conditions.
\end{abstract}

Key words: postembryonic development, predation, pollen, biological control.

\section{INTRODUCTION}

The avocado, Persea americana Mill. (Lauraceae), is the second most cultivated fruit tree in Chile after vineyards, and covers an area of 39302.59 ha of which $56 \%$ is concentrated in the Valparaíso Region (INE, 2007). Furthermore, Chile is the second world exporter of avocados, mainly the Hass variety, with approximately 165000 t exported during the 2006-2007 season (Comité de Paltas, 2007).

Nevertheless, there is an economic loss associated with exports because of the presence of pests such as Pseudococcus longispinus (Targioni \& Tozzetti) (Hemiptera: Pseudococcidae), P. calceolariae (Maskell) (Hemiptera: Pseudococcidae), Hemiberlesia lataniae

${ }^{1}$ Universidad Pontificia Universidad Católica de Valparaíso, Facultad de Agronomía, Casilla 4-D, Quillota, Chile.

"Corresponding author (tommyriojasoto@yahoo.es).

${ }^{2}$ Instituto de Investigaciones Agropecuarias, Centro Regional de Investigación La Cruz, Casilla 3, La Cruz, Chile. (rvargas@inia.cl). Received: 17 January 2008.

Accepted: 19 May 2008.
(Signoret) (Hemiptera: Diaspidiae), and Heliothrips haemorrhoidalis (Bouché) (Thysanoptera: Thripidae) (SAG, 2007). The most important economic avocado pest at a foliar level is Oligonychus yothersi (McGregor) (Acari: Tetranychidae) (Altieri and Rojas, 1999), commonly known as the avocado red mite, and var. Hass is the most susceptible to be attacked by this tetraniquid. Oligonychus yothersi provokes a decrease in photosynthetic rate, stomatal conductance, and transpiration, negatively affecting the physiology of the avocado leaves (Schaffer et al., 1986). This has a direct consequence on the quality of the fruit and crop yield (Palevsky et al., 2007a), the same as for O. perseae Turttle, Baker and Abbatiello (Acari: Tetranychidae) found in California, USA (Kerguelen and Hoddle, 2000; Takano-Lee and Hoddle, 2002).

The natural enemies associated with $O$. yothersi in avocado orchards in the Province of Quillota are Stethorus histrio Chazeau (Coleoptera: Coccinellidae) and Oligota pygmaea Solier (Coleoptera: Staphylinidae), densitydependent generalist predators. Both coleoptera present natural colonization in the orchard only when the pest population increases (Obrycki and Kring, 1998; Kishimoto, 
2003) without exerting the necessary regulation to avoid damage produced by the red mite at the leaf physiological level. This makes it necessary to incorporate new predators to the system to interact with low $O$. yothersi population densities in the Chilean avocado orchards managed with biological control agents.

The most important predators of phytophagous mites in the world belong to the Phytoseiidae (Shrewsbury and Hardin, 2003) family which are easily adaptable to perturbed habitats and intensely managed as is the case of fruit orchards (Croft and Luh, 2004). The generalist species do not require large mite pest population densities to be established in an orchard, and migrate to other places through aerial dispersion if they lack prey (Colfer et al., 2003; Tixier et al., 2006). In the absence of phytophagous mites, the generalists have the capacity to use food alternatives such as pollen grains, fungi spores, insects in the immature stages, plant nectar, and exudates (Croft et al., 2004; Nomikou et al., 2005; Bouras and Papadoulis, 2005).

To include new natural enemies in a biological control system, it is fundamental to know their biological and ecological characteristics. The potential of the predators on their prey (De Vis et al., 2006b) can be estimated through population models and the construction of life tables, thus obtaining data about survival, longevity, reproduction, and descendants of the arthropod populations (Yu et al., 2005; Gabre et al., 2005; Yang and Chi, 2006; Ozman-Sullivan, 2006; Ferrero et al., 2007). Food quality has a great influence on the formulation of biological parameters since it is indispensable to recognize the predator's consumption in each stage of the pest in order to predict its effectiveness as a natural enemy (Kishimoto, 2003; Gotoh et al., 2006; Collier et al., 2007), and potential impact on the prey (Hosseini et al., 2005).

This study evaluated the demographic parameters and the consumption of Cydnodromus picanus, Amblyseius graminis, and Galendromus occidentalis on distinct stages of $O$. yothersi, first under laboratory conditions to identify the red mite's potential predators which would eventually be included in integrated pest management plans.

\section{MATERIALS AND METHODS}

Species studied. Three phytoseiid species were selected and evaluated as potential predators of the avocado red mite based on biological and ecological characteristics. Cydnodromus picanus Ragusa (Parasitiforms: Phytoseiidae) is a type III generalist phytoseiid from the Pica zone (20 $15^{\prime}$ S; 69 $20^{\circ} \mathrm{W}$ ), Tarapacá Region (Ragusa et al., 2000) which is able to withstand great thermal oscillations during throughout the day with scarce environmental humidity, and survive food scarcity. Amblyseius graminis Chant (Parasitiforms: Phytoseiidae) is a type III generalist phytoseiid (Croft et al., 2004) collected on redstem stork's bill (Erodium cicutarium (L.) L’Hér.) (Geraniaceae) in avocado orchards in the La Cruz zone (32 $49^{\prime} \mathrm{S} ; 7^{\circ} 17^{\prime} \mathrm{W}$ ), Valparaíso Region. Galendromus (Metaseiulus) occidentalis (Nesbitt) (Parasitiforms: Phytoseiidae) is a type II specialist phytoseiid (Blackwood et al., 2004) collected on walnut trees (Juglans regia L.) (Juglandaceae) (Ragusa and Vargas, 2002) in Los Andes locality (32 $49^{\prime} \mathrm{S} ; 7^{\circ} 35^{\prime} \mathrm{W}$ ), Valparaíso Region, and is a known mite predator of the Oligonychus genus (Shrewsbury and Hardin, 2003).

Site and study materials. The life table and consumption assays were carried out in the laboratories of Instituto de Investigaciones Agropecuarias (INIA) La Cruz, Valparaíso Region, between January and September 2007. Using a data logger, the Petri dish micro-climatic conditions were registered inside the laboratory, thereby obtaining a temperature of $27 \pm 1.93{ }^{\circ} \mathrm{C}$, relative humidity of $87 \pm 3.61 \%$, and a 16:8 (L:D) photoperiod for all the assays. These micro-climatic conditions were used to register the maximum biological potential of the predatory species since these are susceptible to low humidity in the egg stage (De Vis et al., 2006a). The experimental observations were carried out every 24 $\mathrm{h}$ with a $40 \mathrm{X}$ stereoscopical magnifying glass (Zeiss, Stemi, Göttingen, Germany). An adhesive (Point sticken blue, Point Chile S.A.) was used to avoid the mites from escaping.

Breeding of the avocado red mite. Oligonychus yothersi were bred massively on avocado leaves var. Hass, with a modified methodology (Oliveira et al., 2001) using plastic containers $(29 \times 7 \times 39.5 \mathrm{~cm})$ at a temperature of $27 \pm 2{ }^{\circ} \mathrm{C}$, relative humidity of $50 \pm 10 \%$, and a $16: 8$ (L:D) photoperiod. The micro-climatic conditions were registered with a digital thermo-hygrometer.

Phytoseiid breeding. The three predatory species selected were obtained in the phytoseiid breeding room located in the INIA La Cruz facilities. Subsequently, gravid females of this species were moved to the assay laboratory where they were bred on avocado leaf disks var. Hass infested with $O$. yothersi inside plastic containers (57 $\mathrm{x} 42 \times 19 \mathrm{~cm}$ ) opened at the top and covered with muslin to avoid contamination of the predatory mite populations. The assays were carried out with eggs laid by the firstgeneration females.

Postembryonic development.Egg-adult development was determined for each species of phytoseiid. Thirty gravid females were taken from each species and each female was placed inside an avocado leaf disk var. 
Hass $(\varnothing=5 \mathrm{~cm})$ confined with adhesive (sticken). They were eliminated after 5 h, leaving 1 egg per disk (1 egg = 1 replicate), and registering the duration of each developmental stage of the phytoseiid through the exuvium. Longevity of unmated individuals was obtained by making available, on a daily basis, ten 24-h-old eggs, 10 mobile immature individuals (protonymphs and deutonymphs), and five $O$. yothersi adult females. Daily consumption was registered for each phytoseiid.

Avocado (Persea americana Mill.) (Lauraceae) var. Hass and hairy brassica (Hirschfeldia incana (L.) Lagr.Foss.) (Brassicaceae) pollen was evaluated as alternative food to verify the survival of the species when facing a scarcity of prey. Daily, avocado var. Hass and $H$. incana pollen was provided separately by means of a fine brush, along with registering postembryonic development and predator longevity. Water was provided by cotton threads through a hole in the leaf for assays with pollen, as well as for those without food supply.

Fertility and longevity. Thirty females of known age were placed in avocado var. Hass leaf disks (1 female $=1$ replicate), integrating a male for $24 \mathrm{~h}$ every 7 days. Each female was given 15 mobile immature $O$. yothersi (protonymphs and deutonymphs). The phytoseiid eggs were counted and eliminated, recording longevity, fecundity, and consumption of the gravid females. To obtain descendants and the proportion of sexes, 10 females were randomly selected from the previous 30 . Thus, the eggs of each female were counted and deposited on 10 infested Petri dishes with all the $O$. yothersi stage, respectively, thus recording data about fertility and proportion of sexes for the females of each species.

Statistical analysis. A completely random design was applied with 30 replicates per experiment. Postembryonic development, longevity, and consumption data were transformed by $\sqrt{\mathrm{x}+0.5}$ (Steel and Torrie, 1985). Subsequently, ANOVA and Tukey test $(\mathrm{p}<0.05)$ were applied to evaluate the influence of food on postembryonic development and phytoseiid consumption.

The following were the calculated life table parameters (SAS Institute, 2007): (1) Net reproductive rate, $R_{0}=$ $l_{x} m_{x}$, being the number of females that produce a female during a generation or during their lifespan (Rabinovich, 1980); (2) intrinsic rate of increase, $r_{m}$ being the maximum exponential multiplication rate of a whole population, and calculated as $1=\quad l_{x} m_{x} \exp \left(-\mathrm{r}_{\mathrm{m}}\right)($ Birch, 1948); (3) finite rate of increase, $\lambda=\exp \left(r_{m}\right)$ being the number of females that produce one female per day (Birch, 1948); and (4) generation time, $\mathrm{T}=\quad \mathbf{X} l_{x} m_{x} / \mathrm{R}_{0}$ being the time that passes between first and next generation oviposition (Rabinovich, 1980).

The Jacknife nonparametric resampling method was used to compare the parameters of the life table between species, estimating the mean, variance, and standard error (Meyer et al., 1986; La Rossa and Kahn, 2003) with the LIFETABLES software, SAS (Maia et al., 2000), and SAS ${ }^{\circledR}$ (SAS Institute, 2007). The biological parameters were subsequently compared with the Tukey test $(\mathrm{P}<0.05)$.

\section{RESULTS}

The time of postembryonic development of $C$. picanus observed was less compared to the other two predatory species $(F=134.54, \mathrm{df}=2, \mathrm{p}<0.01)$ when fed mobile immature $O$. yothersi (Table 1). With regard to the longevity of phytoseiids fed with mobile immature O. yothersi, C. picanus showed a greater duration of the adult stage than $A$. graminis and $G$. occidentalis, thus indicating that the supply of $O$. yothersi protonymphs and deutonyphs had a positive influence on the postembryonic development of $C$. picanus $(F=167.30, \mathrm{df}=2, \mathrm{p}<0.01)$. In relation to the percentage of immature phytoseiids that developed to the adult stage, a survival rate of $100 \%$ was registered for C. picanus, $86 \%$ for $G$. occidentalis, and only $10 \%$ for A. graminis.

By feeding $O$. yothersi eggs, the postembryonic development of C. picanus and A. graminis increased with respect to the predators fed with immature red mites, whereas $G$. occidentalis only reached the larval stage. Furthermore, C. picanus showed a $13 \%$ survival rate and A. graminis $6.6 \%$ in the immature stage (Table 1 ). It was confirmed that in the immature stage, C. picanus, A. graminis, and $G$. occidentalis do not consume adult females of the avocado red mite (Table 1).

Using avocado var. Hass pollen, the duration of the postembryonic development was found to be shorter for A. graminis than $C$. picanus $(F=27.55$, $\mathrm{df}=1$, $\mathrm{p}<$ $0.01)$. Regarding longevity of the evaluated species, $A$. graminis individuals were significantly more long-lived $(F=148.18, \mathrm{df}=1, \mathrm{p}<0.0001)$ than $C$. picanus. Survival of immature phytoseiids that reached the adult stage was not significantly different between $A$. graminis (66.6\%) and C. picanus $(43.3 \%)(F=3.38, \mathrm{df}=1, \mathrm{p}=0.0713)$, though $G$. occidentalis did not consume pollen and only developed to the larval stage (Table 2).

Using $H$. incana pollen, egg-adult development was observed to be less for $A$. graminis than C. picanus $(F=177.21, \mathrm{df}=1, \mathrm{p}<0.01)$, although longevity was significantly greater for $A$. graminis $(F=345.48, \mathrm{df}=1$, $\mathrm{p}<0.0001)$ than C. picanus. Furthermore, A. graminis showed a $60 \%$ survival rate of individuals in the immature stage that developed into the adult stage, whereas $C$. picanus registered a statistically similar $46.6 \%(F=1.05$, $\mathrm{df}=1, \mathrm{p}=0.3087)($ Table 2).

In terms of C. picanus longevity, a significant difference was obtained for the individuals fed with mobile immature 
Table 1. Duration of postembryonic development and longevity (in days) of Cydnodromus picanus, Amblyseius graminis, and Galendromus occidentalis fed with Oligonychus yothersi in different stages.

\begin{tabular}{|c|c|c|c|c|c|c|c|}
\hline \multirow[b]{2}{*}{ Daily diet } & \multirow[b]{2}{*}{ State } & \multicolumn{6}{|c|}{ Phytoseiid species (mean \pm SE) } \\
\hline & & $\mathbf{n}$ & C. picanus & $\mathbf{n}$ & A. graminis & $\mathbf{n}$ & G. occidentalis \\
\hline 10 & Egg & 30 & $2.00 \pm 0.00 \mathrm{~b}$ & 30 & $2.00 \pm 0.00 \mathrm{~b}$ & 30 & $3.00 \pm 0.00 \mathrm{a}$ \\
\hline mobile immature & Larva & 30 & $1.00 \pm 0.00 \mathrm{~b}$ & 30 & $1.00 \pm 0.00 \mathrm{~b}$ & 30 & $2.10 \pm 0.00 \mathrm{a}$ \\
\hline \multirow[t]{4}{*}{ O. yothersi } & Protonymph & 30 & $1.03 \pm 0.03 b$ & 28 & $2.07 \pm 0.18 \mathrm{a}$ & 26 & $1.69 \pm 0.09 \mathrm{a}$ \\
\hline & Deutonymph & 30 & $1.60 \pm 0.09 \mathrm{~b}$ & 15 & $2.60 \pm 0.13 a$ & 26 & $1.92 \pm 0.10 b$ \\
\hline & Egg-Adult & 30 & $5.46 \pm 0.10 \mathrm{c}$ & 3 & $7.33 \pm 0.33 b$ & 26 & $8.69 \pm 0.16 \mathrm{a}$ \\
\hline & Adult (longevity) & 30 & $60.03 \pm 1.54 \mathrm{a}$ & 3 & $18.00 \pm 2.08 \mathrm{c}$ & 26 & $29.08 \pm 1.17 b$ \\
\hline 10 & Egg & 30 & $2.00 \pm 0.00 \mathrm{~b}$ & 30 & $2.00 \pm 0.00 \mathrm{~b}$ & 30 & $3.00 \pm 0.00 \mathrm{a}$ \\
\hline O. yothersi & Larva & 30 & $1.00 \pm 0.00 \mathrm{~b}$ & 30 & $1.00 \pm 0.00 \mathrm{~b}$ & 30 & $2.07 \pm 0.11 \mathrm{a}$ \\
\hline \multirow[t]{4}{*}{ eggs } & Protonymph & 29 & $2.89 \pm 0.12 b$ & 21 & $3.80 \pm 0.29 a$ & 0 & - \\
\hline & Deutonymph & 10 & $3.90 \pm 0.31 \mathrm{a}$ & 7 & $3.00 \pm 0.30 \mathrm{a}$ & 0 & - \\
\hline & Egg-Adult & 4 & $9.09 \pm 0.62 \mathrm{a}$ & 2 & $9.50 \pm 0.50 \mathrm{a}$ & 0 & - \\
\hline & Adult (longevity) & 4 & $19.75 \pm 2.42 \mathrm{a}$ & 2 & $9.50 \pm 1.50 \mathrm{~b}$ & 0 & - \\
\hline 5 & Egg & 30 & $2.00 \pm 0.00 \mathrm{~b}$ & 30 & $2.00 \pm 0.00 \mathrm{~b}$ & 30 & $3.00 \pm 0.00 \mathrm{a}$ \\
\hline \multirow{5}{*}{$\begin{array}{l}\text { O. yothersi } \\
\text { adult females }\end{array}$} & Larva & 30 & $1.00 \pm 0.00 \mathrm{~b}$ & 30 & $1.00 \pm 0.00 \mathrm{~b}$ & 30 & $2.40 \pm 0.09 \mathrm{a}$ \\
\hline & Protonymph & 30 & $4.66 \pm 0.08 \mathrm{a}$ & 8 & $2.68 \pm 0.13 b$ & 0 & - \\
\hline & Deutonymph & 0 & - & 0 & - & 0 & - \\
\hline & Egg-Adult & 0 & - & 0 & - & 0 & - \\
\hline & Adult (longevity) & 0 & - & 0 & - & 0 & - \\
\hline
\end{tabular}

Values with distinct letters in the row indicate significant differences according to Tukey $(\mathrm{p}<0.05)$.

SE: standard error. n: number of individuals.

red mites (60.03 days) as compared with administering an exclusive diet of avocado var. Hass pollen (40.46 días) ( $F$ $=62.74, \mathrm{df}=1, \mathrm{p}<0.0001)$ and $H$. incana $(22.5$ días $)(F=$ $251.41, \mathrm{df}=1, \mathrm{p}<0.0001)$, thus indicating that these two latter diets are a feeding alternative when prey is scarce. On the other hand, A. graminis registered a significantly greater longevity when fed avocado var. Hass pollen (78.10 días) $(F=91.36, \mathrm{df}=1, \mathrm{p}<0.10001)$ and $H$. incana (84.94 días) $(F=86.85, \mathrm{df}=1, \mathrm{p}<0.0001)$ compared with feeding on mobile immature red mites (18 days) (Table 1 , Table 2).

On a water diet, C. picanus and A. graminis developed up to the protonymph stage. In contrast, G. occidentalis only reached the larval stage. Furthermore, C. picanus showed a longer duration in the protonymph stage compared with A. graminis $(F=1158.03, \mathrm{df}=1, \mathrm{p}<0.01)$ (Table 2).

As for depredation on immature O. yothersi, G. occidentalis registered consumption of the avocado red mite in the larval stage although $C$. picanus and A. graminis did not present depredation in this stage $(F=457.40, \mathrm{df}=2$, $\mathrm{p}<0.01$ ), indicating that $G$. occidentalis needs to be fed to continue its postembryonic development. On the other hand, C. picanus and $G$. occidentalis registered less depredation in the protonymph stage than A. graminis $(F=32.58$, df $=$
2, $\mathrm{p}<0.01$ ), a behavior also observed in deutonymphs ( $F=$ 13.77, $\mathrm{df}=2, \mathrm{p}<0.01$ ). Nevertheless, unmated $C$. picanus adults showed a greater depredation rate compared with unmated A. graminis and $G$. occidentalis adults $(F=71.96$, $\mathrm{df}=2, \mathrm{p}<0.01)$ (Table 3).

Agreater depredation rate of mated A. graminis females on immature $O$. yothersi was observed as compared with C. picanus and G. occidentalis $(F=306.67, \mathrm{df}=2$, $\mathrm{p}<$ 0.01) (Table3).

\section{Life table parameters}

Cydnodromus picanus females showed gradual mortality over time in contrast with A. graminis and $G$. occidentalis which concentrated almost $80 \%$ mortality in 7 days (Figure 1). Furthermore, greater longevity was noted for A. graminis (25.7 days) and C. picanus (25.43 days) females in contrast with $G$. occidentalis (22.56 days $)(F=5.44, \mathrm{df}=2, \mathrm{p}=0.006)$. The three survival curves recorded for the distinct species were type I, thus indicating that mortality was mainly concentrated in longlived individuals (Rabinovich, 1980).

There is no significant difference in the oviposition rate between the evaluated phytoseiid species $(\mathrm{F}=1.47$, $\mathrm{df}=2, \mathrm{p}=0.236$ ) (Figure 2). Comparing female fertility, C. picanus had a higher value than G. occidentalis and 
Table 2. Influence of diet on duration of postembryonic development and longevity (in days) of Cydnodromus picanus, Amblyseius graminis, and Galendromus occidentalis.

\begin{tabular}{|c|c|c|c|c|c|c|c|}
\hline \multirow[b]{2}{*}{ Daily diet } & \multirow[b]{2}{*}{ State } & \multicolumn{6}{|c|}{ Phytoseiid species (mean \pm SE) } \\
\hline & & $S^{1}(\%)$ & C. picanus & S (\%) & A. graminis & S(\%) & G. occidentalis \\
\hline \multirow{6}{*}{$\begin{array}{l}\text { Persea americana } \\
\text { var. Hass pollen }\end{array}$} & Egg & 100a & $2.00 \pm 0.00 \mathrm{~b}$ & 100a & $2.00 \pm 0.00 \mathrm{~b}$ & $100 a$ & $3.00 \pm 0.00 a$ \\
\hline & Larva & $100 \mathrm{a}$ & $1.00 \pm 0.00 \mathrm{~b}$ & $100 \mathrm{a}$ & $1.00 \pm 0.00 \mathrm{~b}$ & $100 \mathrm{a}$ & $1.13 \pm 0.06 \mathrm{a}$ \\
\hline & Protonymph & $96.6 \mathrm{a}$ & $4.37 \pm 0.18 \mathrm{a}$ & $66.6 \mathrm{~b}$ & $2.40 \pm 0.13 b$ & $0 \mathrm{c}$ & - \\
\hline & Deutonymph & $73.3 \mathrm{a}$ & $3.50 \pm 0.20 \mathrm{a}$ & $66.6 \mathrm{a}$ & $2.40 \pm 0.21 b$ & $0 \mathrm{~b}$ & - \\
\hline & Egg-Adult & $43.3 \mathrm{a}$ & $10.86 \pm 0.52 \mathrm{a}$ & $66.6 \mathrm{a}$ & $7.80 \pm 0.26 \mathrm{~b}$ & $0 \mathrm{~b}$ & - \\
\hline & Adult (longevity) & $43.3 \mathrm{a}$ & $40.46 \pm 1.11 b$ & $66.6 \mathrm{a}$ & $78.10 \pm 2.37 \mathrm{a}$ & $0 \mathrm{~b}$ & - \\
\hline \multirow{6}{*}{$\begin{array}{l}\text { Hirschfeldia } \\
\text { incana } \\
\text { pollen }\end{array}$} & Egg & 100a & $2.00 \pm 0.00 \mathrm{~b}$ & 100a & $2.00 \pm 0.00 \mathrm{~b}$ & $100 \mathrm{a}$ & $3.00 \pm 0.00 \mathrm{a}$ \\
\hline & Larva & 100a & $1.00 \pm 0.00 \mathrm{~b}$ & 100a & $1.00 \pm 0.00 \mathrm{~b}$ & $100 \mathrm{a}$ & $1.03 \pm 0.03 a$ \\
\hline & Protonymph & $93.3 \mathrm{a}$ & $2.67 \pm 0.14 \mathrm{a}$ & $60 \mathrm{~b}$ & $1.00 \pm 0.00 \mathrm{~b}$ & $0 \mathrm{c}$ & - \\
\hline & Deutonymph & $83.3 \mathrm{a}$ & $3.04 \pm 0.12 \mathrm{a}$ & $60 \mathrm{~b}$ & $1.05 \pm 0.05 b$ & $0 \mathrm{c}$ & - \\
\hline & Egg-Adult & $46.6 \mathrm{a}$ & $8.68 \pm 0.26 a$ & $60 \mathrm{a}$ & $5.05 \pm 0.05 b$ & $0 \mathrm{~b}$ & - \\
\hline & Adult (longevity) & $46.6 \mathrm{a}$ & $22.50 \pm 0.97 b$ & $60 \mathrm{a}$ & $84.94 \pm 2.85 \mathrm{a}$ & $0 \mathrm{~b}$ & - \\
\hline \multirow[t]{6}{*}{ Water } & Egg & $100 \mathrm{a}$ & $2 \pm 0.0 \mathrm{~b}$ & $100 \mathrm{a}$ & $2.00 \pm 0.00 \mathrm{~b}$ & $100 \mathrm{a}$ & $3.00 \pm 0.00 \mathrm{a}$ \\
\hline & Larva & $100 \mathrm{a}$ & $1 \pm 0.0 \mathrm{~b}$ & $100 \mathrm{a}$ & $1.00 \pm 0.00 \mathrm{~b}$ & $100 \mathrm{a}$ & $1.15 \pm 0.06 \mathrm{a}$ \\
\hline & Protonymph & $100 \mathrm{a}$ & $4.73 \pm 0.08 \mathrm{a}$ & $66.6 \mathrm{~b}$ & $1.10 \pm 0.06 \mathrm{~b}$ & $0 \mathrm{c}$ & - \\
\hline & Deutonymph & - & - & - & - & - & - \\
\hline & Egg-Adult & - & - & - & - & - & - \\
\hline & Adult (longevity) & - & - & - & - & - & - \\
\hline
\end{tabular}

Distinct letters indicate significant differences according to Tukey $(\mathrm{p}<0.05)$.

$\mathrm{S}^{1}$ : survival of individuals expressed in \%. SE: standard error. $\mathrm{n}$ : number of individuals.

A. graminis whose eggs were almost entirely infertile (Figure 3).

The life table parameters of the three phytoseiids fed with immature $O$. yothersi showed that $C$. picanus showed higher $\mathrm{R}_{0}, \mathrm{r}_{\mathrm{m}}$, and $\lambda$ than $G$. occidentalis $(F=233.58$, $\mathrm{df}=$ $3, \mathrm{p}<0.0001 ; F=2390.05, \mathrm{df}=3, \mathrm{p}<0.0001 ; F=215.61$, $\mathrm{df}=3, \mathrm{p}<0.0001 ; F=2127.12, \mathrm{df}=3, \mathrm{p}<0.0001)$, whereas A. graminis revealed $\mathrm{R}_{0}=0.27$ indicating that the population of this specie decreases over time (Table 4). The biological parameters of C. picanus show that the population grew 25.41 times in 12.46 days $(\mathrm{T})$, and for each female of the actual generation there will be 25.41 females in the next generation. Furthermore, for each female present on a given day, there will be almost 1.29 $(\lambda)$ females the next day. Therefore, at any particular point in time, the number of females in the $C$. picanus population will increase at such a rate that a population growth of $25 \%\left(\mathrm{r}_{\mathrm{m}}\right)$ is expected from one day to the next. Moreover, comparing $\mathrm{R}_{0}, \mathrm{r}_{\mathrm{m}}, \mathrm{T}$, and $\lambda$ of $C$. picanus with $O$. yothersi, it is observed that only the latter attains a higher $\mathrm{R}_{0}(F=233.58, \mathrm{df}=3, \mathrm{p}<0.0001)$, while the predator registered higher $r_{m}$ and $\lambda$. In addition, generation time was significantly lower for $C$. picanus $(F=215.61, \mathrm{df}=3$, $\mathrm{p}<0.0001$ ) demonstrating that it multiplied more rapidly than the red mite population (Table 4).

\section{DISCUSSION}

Consumption records during the postembryonic development of the three phytoseiids in the $O$. yothersi egg, immature, and adult female stages indicated that protonymphs and deutonymphs of the avocado red mite are differentially predated by C. picanus, A. graminis, and G. occidentalis. This influenced the depredation rate by, morphology, prey stage, and the predators' mouth parts (Croft et al., 2004), since the integuments of O. yothersi adult females are more difficult to penetrate than those of immature prey (Kishimoto y Takagi, 2001; Furuichi et al., 2005).

Regarding consumption, Ragusa et al. (2000) established that $C$. picanus fed with Tetranychus urticae C.L. Koch (Tetranychidae) eggs reach the adult stage in approximately 4 days, demonstrating a positive influence of this prey in the development of the phytoseiid compared with $O$. yothersi. This would be explained by $T$. urticae egg morphology: spherical and easy to handle by the phytoseiids. In contrast, $O$. yothersi eggs adhere to the surface of the avocado leaf making it difficult to capture, and consequently less attractive as food (Vantornhout, 2006). 


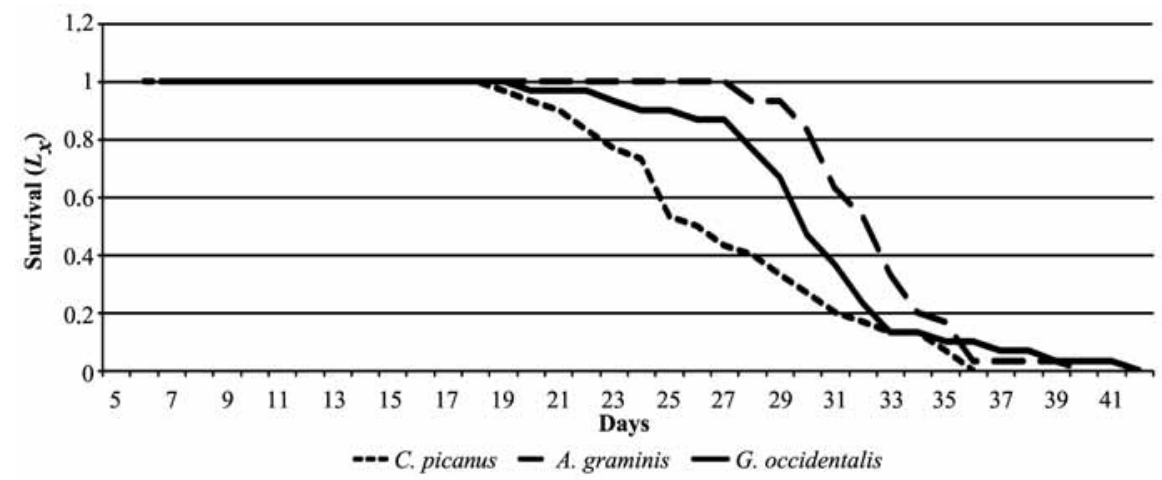

Figure 1. Survival curve of mated female Cydnodromus picanus, Amblyseius graminis, and Galendromus occidentalis fed with mobile immature Oligonychus yothersi.

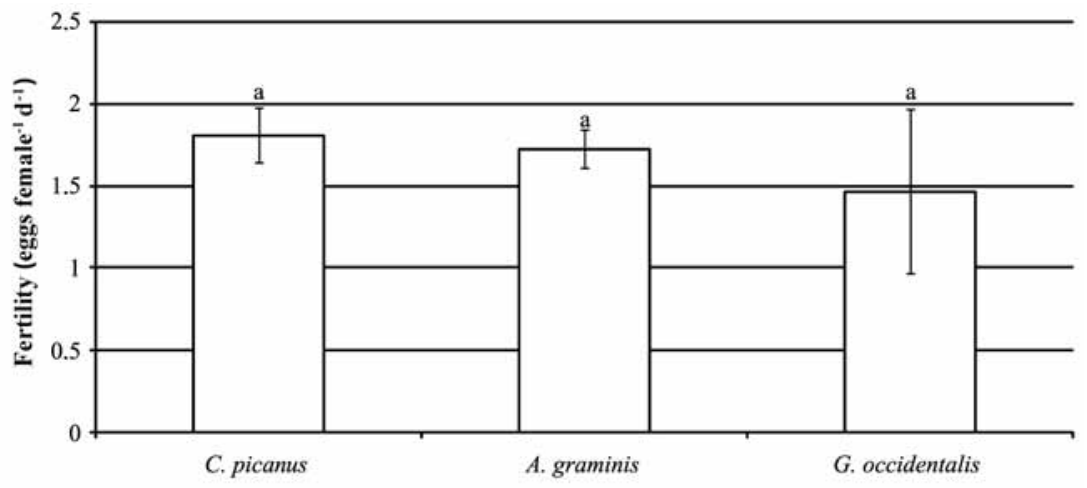

Phytoseiid species

Distinct letters indicate significant differences according to Tukey $(\mathrm{p}<0.05)$.

Figure 2. Female fertility of Cydnodromus picanus, Amblyseius graminis, and Galendromus occidentalis fed with mobile immature Oligonychus yothersi.

The established classification with regard to alternative food was confirmed by pointing out $C$. picanus and $A$. graminis as type III generalists and G. occidentalis as a recognized type II specialist preferring the Oligonychus genus (Shrewsbury and Hardin, 2003; Croft et al., 2004). Both generalists would be more adapted to conditions of food scarcity than $G$. occidentalis which need to feed on mites in order to develop. Ragusa et al. (2000) gave Oxalis sp. and Ricinus sp. pollen to C. picanus exhibiting survival rates of $52 \%$ and $44 \%$, respectively in the immature stage. When fed with avocado var. Hass pollen, $43.3 \%$ of the population survived, converting it into an ideal alternative food in the absence of the red mite, and demonstrating another comparative advantage over $G$. occidentalis. It is also worth mentioning that $G$. occidentalis in commercial orchards is easily displaced by type III generalist phytoseiids. Slow and smaller-sized, it can also be transformed into prey for phytoseiids, and easily depredated by coleopters belonging to the Stethorus and Oligota genera (Colfer et al., 2003). Therefore, possible field releases of $G$. occidentalis could only be carried out when the $O$. yothersi population is high in the orchard, without being able to avoid the physiological damage provoked by the red mite on avocado leaves.

When O. yothersi population density is low and within a context of habitat management, it would be possible to carry out preventive releases of $C$. picanus starting in September using $H$. incana pollen, as well as avocado pollen, as an alternative food, since this Brassicaceae is associated to avocado orchards in the Valparaíso Region and could be used as a refuge in hillside commercial plantations (Bouras and Papadoulis, 2005; Palevsky et al., 2007b).

Mated A. graminis females showed a high rate of total consumption, but their eggs were infertile with no descendants over time compared with $C$. picanus that hatched almost $100 \%$ of its eggs. Regarding this phenomenon, several authors have pointed out a likeness 
Table 3. Total consumption by Cydnodromus picanus, Amblyseius graminis, and Galendromus occidentalis of mobile immature Oligonychus yothersi during postembryonic development and longevity of predator mites.

\begin{tabular}{llrrr}
\hline & & \multicolumn{3}{c}{ Phytoseiid species (mean \pm SE) } \\
\cline { 3 - 5 } Prey & Phytoseiid state & \multicolumn{1}{c}{ C. picanus } & A. graminis & G. occidentalis \\
\hline Mobile immature & Larva & $0.00 \pm 0.00 \mathrm{~b}$ & $0.00 \pm 0.00 \mathrm{~b}$ & $1.73 \pm 0.10 \mathrm{a}$ \\
O. yothersi & Protonymph & $2.00 \pm 0.14 \mathrm{~b}$ & $4.17 \pm 0.32 \mathrm{a}$ & $2.34 \pm 0.11 \mathrm{~b}$ \\
& Deutonymph & $2.63 \pm 0.11 \mathrm{~b}$ & $3.93 \pm 0.38 \mathrm{a}$ & $2.50 \pm 0.12 \mathrm{~b}$ \\
& Unmated adult & $59.20 \pm 1.66 \mathrm{a}$ & $39.66 \pm 2.02 \mathrm{~b}$ & $34.88 \pm 1.34 \mathrm{~b}$ \\
& Mated female & $142.76 \pm 6.34 \mathrm{~b}$ & $298.53 \pm 7.44 \mathrm{a}$ & $90.30 \pm 3.49 \mathrm{c}$ \\
\hline
\end{tabular}

Values with different letters in the rows indicate significant differences according to Tukey $(\mathrm{p}<0.05)$.

SE: standard error.

Table 4. Life table parameters of the Cydnodromus picanus, Amblyseius graminis, Galendromus occidentalis predator mites, and the avocado red mite Oligonychus yothersi.

\begin{tabular}{lcccc}
\hline \multirow{2}{*}{$\begin{array}{l}\text { Biological } \\
\text { parameters }\end{array}$} & \multicolumn{4}{c}{ Species (mean \pm SE) } \\
\cline { 2 - 5 } & ${\text { C. } \text { picanus }^{1}}^{1}$ & ${\text { A. } \text { graminis }^{1}}^{1}$ & G. occidentalis $^{1}$ & O. yothersi \\
\hline $\mathrm{R}_{0}$ & $25.41 \pm 1.14 \mathrm{~b}$ & $0.27 \pm 0.01 \mathrm{~d}$ & $16.25 \pm 0.68 \mathrm{c}$ & $39.66 \pm 1.84 \mathrm{a}$ \\
$\mathrm{r}_{\mathrm{m}}$ & $0.25 \pm 0.00 \mathrm{a}$ & $-0.06 \pm 0.00 \mathrm{~d}$ & $0.19 \pm 0.00 \mathrm{c}$ & $0.22 \pm 0.00 \mathrm{~b}$ \\
$\mathrm{~T}$ & $12.46 \pm 0.16 \mathrm{~d}$ & $20.75 \pm 0.31 \mathrm{a}$ & $14.62 \pm 0.25 \mathrm{c}$ & $16.36 \pm 0.19 \mathrm{~b}$ \\
$\lambda$ & $1.29 \pm 0.00 \mathrm{a}$ & $0.93 \pm 0.00 \mathrm{~d}$ & $1.20 \pm 0.00 \mathrm{c}$ & $1.25 \pm 0.00 \mathrm{~b}$ \\
$\mathrm{n}$ & 30 & 30 & 30 & 25 \\
\hline
\end{tabular}

Values with different letters in the rows indicate significant differences according to Tukey $(\mathrm{p}<0.05)$.

${ }^{1}$ Daily diet $=15$ mobile immature $O$. yothersi. SE: standard error. n: number of individuals. $\mathrm{R}_{0}$ : net reproductive rate. rm: net intrinsic rate of increase.

T: mean generation time. $\lambda$ : finite rate of increase.

to sequestration or extraction of secondary metabolites from plants, that is, specialist phytophages such as $O$. yothersi would be extracting alelochemicals from the avocado which would then be stored in their bodies as a defense against their predators, thus affecting in distinct ways the three evaluated phytoseiid species (Aregullín and Rodríguez, 2003; Collier et al., 2007; Zhu-Salzman et al., 2008). For this reason, it is necessary to carry out studies to confirm the presence of these toxic substances found in the red mite and predators. On the other hand, phytophages that have a broad range of host plants do not have the capacity to extract these toxic substances (Trigo, 2000; Termonia et al., 2001). Nishida (2002) points out that these substances extracted from the plants are biochemically transformed before being stored in the bodies of lepidopters. It must also be mentioned that endosymbiontic fungi are present in the plants and influence the tri-trophic interactions (plant-pest-natural enemy), affecting predator development, survival, and reproduction for the production of toxic alkaloids (mycotoxins) (De Sassi et al., 2006).

It must be mentioned that studies evaluating predators based on consumption or female fertility rates do not determine a potential control of the pest and provide incomplete information. High consumption rates do not imply high female fertility and fecundity, since A. graminis showed higher consumption and an oviposition rate similar to C. picanus and G. occidentalis. However, evaluating fecundity, $C$. picanus had a higher mean of eggs able to develop to the adult stage. It is therefore necessary to determine key biological parameters in ideal conditions to observe the biotic potential of the species of interest.

Establishing life and fecundity tables of predators and prey are fundamental to evaluate the efficiency and potentiality of a natural enemy on a specific pest (Naranjo, 2001; Gabre et al., 2005; Vantornhout et al., 2005; OzmanSullivan, 2006; Collier et al., 2007; Reis et al., 2007; Ferrero et al., 2007; Broufas et al., 2007). The abovementioned information along with consumption registers generate assumptions of potential predator efficiency in the orchard (Chi and Yang, 2003; Kishimoto, 2003; Hosseini et al., 2005; Gotoh et al., 2006). This knowledge is relevant particularly for the assessment of natural enemies that are commercially produced (O’Neil et al., 1998).

In reference to the biological parameters, intrinsic rate of increase $\left(r_{m}\right)$ indicates the capacity of the population to multiply in one generation, relating net reproductive rate $\left(\mathrm{R}_{0}\right)$ on generation time (T) (Rabinovich, 1980), implying the potential control of a natural enemy on a specific 


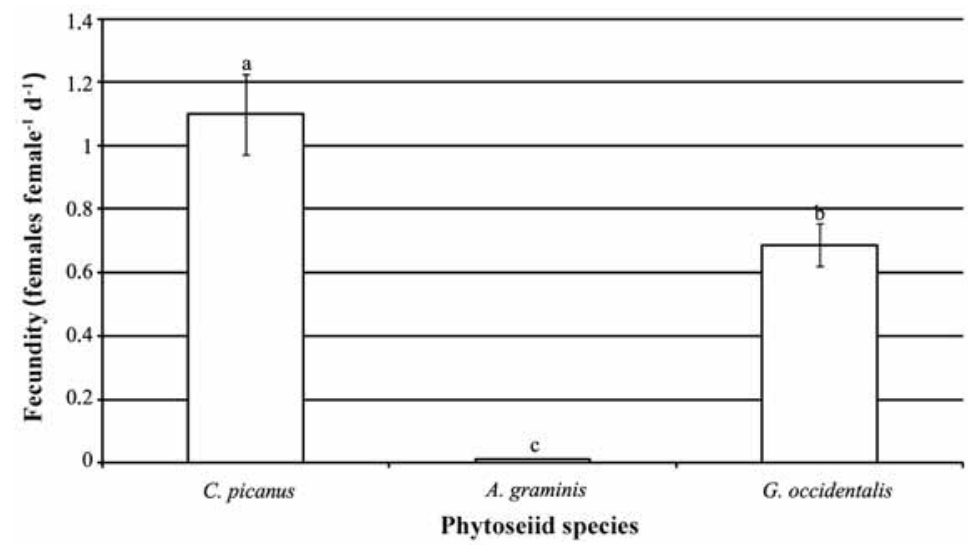

Distinct letters indicate significant differences according to Tukey $(\mathrm{p}<0.05)$.

Figure 3. Mean female fecundity of Cydnodromus picanus, Amblyseius graminis, and Galendromus occidentalis fed with mobile immature Oligonychus yothersi.

pest (Persad y Khan, 2002; Kontodimas et al., 2007). In theory, associating predator intrinsic rate of increase on the prey intrinsic rate of increase, shown by the equation $\mathrm{r}_{\mathrm{m}}$ predator $/ \mathrm{r}_{\mathrm{m}}$ pest $\geq 1$, will indicate an efficiency potential to regulate the pest population. Other important parameters must also be considered such as longevity, predatory capacity, and early prey detection ability in selecting efficient biological control (Fiaboe et al., 2007). Cydnodromus picanus achieved a higher $\mathrm{r}_{\mathrm{m}}$ than the red mite, signifying that this population has the capacity to control $O$. yothersi across generations, that is, this species of phytoseiid is an efficient natural enemy of the phytophage mite, and its potential use should be evaluated in the integrated management of avocado mites.

Regarding phytoseiid field releases, all the factors that can influence its effectiveness on a specific phytophage mite must be considered, such as domatia of the host plant (morphological structures of the leaf: depressions, tricomes, cavities between the midrib, and secondary veins that provide refuge for the predator mites generating mutualism) (Matos et al., 2004), chaetotaxia of the predator (length of the dorsoventral setae) (Croft et al., 2004), alternative food availability (Bouras and Papadoulis, 2005), host plant, and leaf area (Collier et al., 2007).

\section{CONCLUSIONS}

Given the phytoseiid species under evaluation: $C$. picanus, A. graminis, and G. occidentalis, it can be concluded that:

C. picanus and $G$. occidentalis complete their postembryonic development and are able to reproduce by feeding on immature avocado red mites in laboratory conditions, both considered as potential predators of
O. yothersi. However, G. occidentalis requires prey in the larval stage for its development and without using alternative food.

A. graminis has no descendants when feeding on mobile immature O. yothersi. However, its population could be increased in the orchard through a habitat management program since it survives by feeding on avocado var. Hass and $H$. incana pollen as alternative food.

A new predator-prey interaction was established under laboratory conditions (C. picanus-O. yothersi). Field releases in the spring of $C$. picanus upheld its potentiality as a predator of the avocado red mite in the context of Integrated Pest Management.

\section{RESUMEN}

Parámetros de tabla de vida y tasa de consumo de Cydnodromus picanus Ragusa, Amblyseius graminis Chant y Galendromus occidentalis (Nesbitt), sobre la arañita roja del palto Oligonychus yothersi (McGregor) (Acari: Phytoseiidae, Tetranychidae). En Chile la arañita roja del palto Oligonychus yothersi (McGregor) es la plaga más importante a nivel foliar en huertos comerciales afectando la fisiología de la hoja, siendo necesaria la búsqueda de nuevos enemigos naturales que interactúen a bajas densidades poblacionales de $O$. yothersi. Se evaluó en condiciones de laboratorio $(27 \pm$ $1,93{ }^{\circ} \mathrm{C}, 87 \pm 3,61 \%$ H.R. y un fotoperíodo de 16:8 (L: O)) sobre discos de hojas de palto (Persea americana Mill.) var. Hass $(\varnothing=5 \mathrm{~cm})$ la potencialidad de ácaros depredadores Cydnodromus picanus Ragusa, Amblyseius graminis Chant y Galendromus occidentalis (Nesbitt), suministrando huevos inmaduros y hembras adultas de $O$. yothersi separadamente, registrando desarrollo 
postembrionario, consumo y parámetros de tabla de vida. El desarrollo postembrionario de C. picanus fue significativamente menor (5,46 días) en comparación a A. graminis (7,33 días) y G. occidentalis (8,69 días) al ser alimentados con inmaduros de O. yothersi. Los parámetros de tabla de vida de $C$. picanus fueron tasa neta de reproducción $\mathrm{R}_{0}=25,41$, tasa finita de crecimiento $\lambda=$ 1,29 y tiempo generacional $\mathrm{T}=12,46$. La tasa intrínseca de crecimiento $\left(\mathrm{r}_{\mathrm{m}}\right)$ fue significativamente mayor para C. picanus $\left(\mathrm{r}_{\mathrm{m}}=0,25\right)$ frente a $G$. occidentalis $\left(\mathrm{r}_{\mathrm{m}}=\right.$ 0,19), mientras que A. graminis presentó una $r_{\mathrm{m}}=-0,06$ indicando que su población no tiene descendencia. El $r_{n}$ registrado por $C$. picanus en condiciones de laboratorio es un indicador del potencial que tiene como depredador sobre $O$. yothersi, y permite suponer que en condiciones de campo el patrón de reducción poblacional de la plaga podría mantenerse.

Palabras clave: desarrollo postembrionario, depredación, polen, control biológico.

\section{LITERATURE CITED}

Altieri, M., and A. Rojas. 1999. Ecological impacts of Chile's neoliberal policies, with special emphasis on agroecosystems. Environment, Development and Sustainability 1:55-72.

Aregullín, M., and E. Rodríguez. 2003. Sesquiterpene lactone sequestration by the tortoise beetle Physonota arizonae (Cassidinae). Revista de la Sociedad Química de México 47(2):143-145.

Birch, L.C. 1948. The intrinsic rate of natural increase of and insect population. J. Anim. Ecol. 17:15-26.

Blackwood, J.S., H.-K. Luh, and B.A. Croft. 2004. Evaluation of prey-stage preference as an indicator of life-style type in phytoseiid mites. Exp. Appl. Acarol. 33:261-280.

Bouras, S.L., and G.TH. Papadoulis. 2005. Influence of selected fruit tree pollen on life history of Euseius stipulatus (Acari: Phytoseiidae). Exp. Appl. Acarol. 36:1-14.

Broufas, G.D., M.L. Pappas, and D.S. Koveos. 2007. Development, survival, and reproduction of the predatory mite Kampimodromus aberrans (Acari: Phytoseiidae) at different constant temperatures. Environ. Entomol. 36(4):657-665.

Chi, H., and T. Yang. 2003. Two-Sex life table and predation rate of Propylaea japonica Thunberg (Coleoptera: Coccinellidae) fed on Myzus persicae (Sulzer) (Homoptera: Aphididae). Environ. Entomol. 32(2):327-333.
Colfer, R.G., J.A. Rosenheim, L.D. Godfrey, and C.L. Hsu. 2003. Interactions between the augmentatively released predaceous mite Galendromus occidentalis (Acari: Phytoseiidae) and naturally occurring generalist predators. Environ. Entomol. 32(4):840-852.

Collier, K.F., G.S. Albuquerque, J.O. de Lima, A. Pallini, and A.J. Molina-Rugama. 2007. Neoseiulus idaeus (Acari: Phytoseiidae) as a potential biocontrol agent of the two-spotted spider mite, Tetranychus urticae (Acari: Tetranychidae) in papaya: performance on different prey stage-host plant combinations. Exp. Appl. Acarol. 41:27-36.

Comité de paltas. 2007. Comité de paltas, Santiago, Chile. Available at http://paltahass.cl/html/mapa/index.htm (Accessed 11 December 2007).

Croft, B.A., J.S. Blackwood, and J.A. McMurtry. 2004. Classifying life-style types of phytoseiid mites: diagnostic traits. Exp. Appl. Acarol. 33:247-260.

Croft, B.A., and H.-K. Luh. 2004. Phytoseiid mites on unsprayed apple trees in Oregon, and other western states (USA): distributions, life-style types and relevance to commercial orchards. Exp. Appl. Acarol. 33:281-326.

De Sassi, C., C.B. Müller, and J. Krauss. 2006. Fungal plant endosymbionts alter life history and reproductive success of aphid predators. Proc. R. Soc. London, Ser. B 273:1301-1306.

De Vis, R.M., G.J. de Moraes, and M.R. Bellini. 2006a. Effect of air humidity on the egg viability of phytoseiid mites Acari: Phytoseiidae, Stigmaeidae common on rubber trees in Brazil. Exp. Appl. Acarol. 38:25-32.

De Vis, R.M., G.J. de Moraes, and M.R. Bellini. 2006b. Inicial screening of little known predatory mites in Brazil as potential pest control agents. Exp. Appl. Acarol. 39:115-125.

Ferrero, M., G. Moraes, S. Kreiter, M. Tixier, and M. Knapp. 2007. Life tables of the predatory mite Phytoseiulus longipes feeding on Tetranychus evansi at four temperatures (Acari: Phytoseiidae, Tetranychidae). Exp. Appl. Acarol. 41:45-53.

Fiaboe, K.K.M., M.G.C. Gondim Jr., G.J. de Moraes, C.K.P.O. Ogol, and M. Knapp. 2007. Bionomics of the acarophagous ladybird beetle Stethorus tridens fed Tetranychus evansi. J. Appl. Entomol. 131(5):355361.

Furuichi, H., K. Oku, S. Yano, A. Takafuji, and M. Osakabe. 2005. Why does the predatory mite Neoseiulus womersleyi Schicha (Acari: Phytoseiidae) prefer spider mite eggs to adults? Appl. Entomol. Zool. 40(4):675-678.

Gabre, R.M., F.K. Adham, and H. Chi. 2005. Life table of Chrysomya megacephala (Fabricius) (Diptera: Calliphoridae). Acta Oecol. 27:179-183. 
Gotoh, T., A. Tsuchiya, and Y. Kitashima. 2006. Influence of prey on developmental performance, reproduction and prey consumption of Neoseiulus californicus (Acari: Phytoseiidae). Exp. Appl. Acarol. 40:189-204.

Hosseini, M., B. Hatami, A. Savoir, H. Allahyari, and A. Ashouri. 2005. Predation by Allothrombium pulvinum on the spider mites Tetranychus urticae and Amphitetranychus viennensis: predation rate, prey preference and functional response. Exp. Appl. Acarol. 37:173-181.

INE. 2007. Instituto Nacional de Estadística, Santiago, Chile. Available at http://www.censoagropecuario. cl/noticias/07/11/files/10.xls (Accessed 11 December 2007).

Kerguelen, V., and M. Hoddle. 2000. Comparison of the susceptibility of several cultivars of avocado to the persea mite, Oligonychus perseae (Acari: Tetranychidae). Sci. Hortic. (Canterbury, Engl.) 84:101-114.

Kishimoto, H. 2003. Development and oviposition of predacious insects, Stethorus japonicus (Coleoptera: Coccinellidae), Oligota Kashmirica benefica (Coleoptera: Staphylinidae), and Scolothrips takahashii (Thysanoptera: Thripidae) reared on different spider mite species (Acari: Tetranychidae). Appl. Entomol. Zool. 38:15-21.

Kishimoto, H., and K. Takagi. 2001. Evaluation of predation on Panonychus citri (McGregor) (Acari: Tetranychidae) from feeding traces on eggs. Appl. Entomol. Zool. 36(1):91-95.

Kontodimas, D.C., P.G. Milonas, G.J. Stathas, L.P. Economou, and N.G. Kavallieratos. 2007. Life table parameters of the pseudococcid predators Nephus includens and Nephus bisignatus (Coleoptera: Coccinellidae). Eur. J. Entomol. 104:407-415.

La Rossa, R., y N. Kahn. 2003. Dos programas de computadora para confeccionar tablas de vida de fertilidad y calcular parámetros biológicos y demográficos en áfidos (Homoptera: Aphidoidea). RIA (Argentina) 32(3):127-142.

Maia, A.H., A.J. Luiz, and C. Campanhola. 2000. Statistical inference on associated fertility life table parameters using Jackknife technique: Computational aspects. J. Econ. Entomol. 93(2):511-518.

Matos, C.H., A. Pallini, F.F. Chaves, and C. Galbiati. 2004. Domácias do cafeeiro beneficiam o ácaro Predador Iphiseiodes zuluagai Denmark and Muma (Acari: Phytoseiidae)? Neotrop. Entomol. 33(1):057-064.

Meyer, J.S., C.G. Ingersoll, L.L. McDonald, and M.S. Boyce. 1986. Estimating uncertainty in population growth rates: Jackknife vs. bootstrap techniques. Ecology 67(5):1156-1166.
Naranjo, S.E. 2001. Conservation and evaluation of natural enemies in IPM systems for Bemisia tabaci. Crop Prot. 20:835-852.

Nishida, R. 2002. Sequestration of defensive substances from plants by lepidoptera. Annu. Rev. Entomol. 47:57-92.

Nomikou, M., R. Meng, R. Schraag, M.W. Sabelis, and A. Janssen. 2005. How predatory mites find plants with whitefly prey. Exp. Appl. Acarol. 36:263-275.

Obrycki, J.J., and T.J. Kring. 1998. Predaceous Coccinellidae in biological control. Ann. Rev. Entomol. 43:295-321.

Oliveira, R.C., L.F. Alves, e P.M. Neves. 2001. Técnica para desenvolvimento de bioensaios com Oligonychus yothersi (Acari: Tetranychidae) em laboratório. Arq. Inst. Biol., São Paulo 68(2):125-126.

O’Neil, R.J., K.L. Giles, J.J. Obrycki, D.L. Mahr, J.C. Legaspi, and K. Katovich. 1998. Evaluation of the quality of four commercially available natural enemies. Biol. Control 11:1-8.

Ozman-Sullivan, S.K. 2006. Life history of Kampimodromus aberrans as a predator of Phytoptus avellanae (Acari: Phytoseiidae, Phytoptidae). Exp. Appl. Acarol. 38:15-23.

Palevsky, E., Y. Maoz, S. Gal, Y. Argov, M. Zilberstein, M. Noy, Y. Izhar, y V. Alchanatis. 2007a. Establecimiento de un umbral de acción para el ácaro de la palta. p. 46. In VI Congreso Mundial de la Palta, Viña del Mar, Chile. 12-16 de noviembre de 2007. Comité de Paltas y Pontificia Universidad Católica de Valparaíso, Viña del Mar, Chile.

Palevsky, E., Y. Maoz, S. Gal, Y. Argov, M. Berkeley, M. Zilberstein, et al. 2007b. Potenciales depredadores nativos y exóticos para el control biológico de la reciente introducción del ácaro de la palta, Oligonychus perseae en huertos de palto en Israel. p. 49. In VI Congreso Mundial de la Palta, Viña del Mar, Chile. 12-16 de noviembre de 2007. Comité de Paltas y Pontificia Universidad Católica de Valparaíso, Viña del Mar, Chile.

Persad, A., and A. Khan. 2002. Comparison of life table parameters for Maconellicoccus hirsutus, Anagyrus kamali, Cryptolaemus montrouzieri and Scymnus coccivora. Biocontrol 47:137-149.

Rabinovich, J.E. 1980. Introducción a la ecología de poblaciones animales. 313 p. Editorial Continental, México.

Ragusa, S., and R. Vargas. 2002. On some phytoseiid mites (Parasitiformes: Phytoseiidae) from Chile. Phytophaga 12:129-139. 
Ragusa, S., R. Vargas, H. Tsolakis, and R. Ashbach. 2000. Laboratory studies on the influence of various food substances on some biological and lifetable parameters of Cydnodromus picanus Ragusa (Parasitiformes: Phytoseiidae) associated with Citrus trees in the Chilean desert. Phytophaga 10:11-23.

Reis, P.R., A.V. Teodoro, M.P. Neto, and E.A. Da Silva. 2007. Life history of Amblyseius herbicolus (Chant) (Acari: Phytoseiidae) on coffee plants. Neotrop. Entomol. 36(2):282-287.

SAG. 2007. Servicio Agrícola y Ganadero, Santiago, Chile. Available at http://www2.sag.gob.cl/reqmercado/ consulta_agricola.asp (Accessed 11 December 2007).

SAS Institute. 2007. SAS system for Windows 2000, version 8.2. SAS Institute, Cary, North Carolina, USA.

Schaffer, B., J. Peña, S.P. Lara, and D. Buisson. 1986. Net photosynthesis, transpiration, and stomatal conductance of avocado leaves infested by avocado red mites. Proc. Interamerican Soc. Tropical Hortic. 30:73-77.

Shrewsbury, P.M., and M.R. Hardin. 2003. Evaluation of predatory mite (Acari: Phytoseiidae) releases to suppress spruce spider mites, Oligonychus ununguis (Acari: Tetranychidae), on Juniper. J. Econ. Entomol. 96(6):1675-1684.

Steel, R., y J.H. Torrie. 1985. Bioestadística: principios y procedimientos. 622 p. McGraw-Hill, Santafé de Bogotá, Colombia.

Takano-Lee, M., and M.S. Hoddle. 2002. Oligonychus perseae (Acari: Tetranychidae) population responses to cultural control attempts in an avocado orchard. Fla. Entomol. 85(1):216-226.

Termonia, A., J.M. Pasteels, D.M. Windsor, and M.C. Milinkovitch. 2001. Dual chemical sequestration: a key mechanism in transitions among ecological specialization. Proc. R. Soc. London, Ser. B 269:1-6.
Tixier, M., S. Kreiter, B. Cheval, S. Guichou, P. Auger, and R. Bonafos. 2006. Immigration of phytoseiid mites from surrounding uncultivated areas into a newly planted vineyard. Exp. Appl. Acarol. 39:227-242.

Trigo, J.R. 2000. The chemistry of antipredator defense by secondary compounds in Neotropical lepidoptera: Facts, perspectives and caveats. J. Braz. Chem. Soc. 11(6):551-561.

Vantornhout, I. 2006. Biology and ecology of the predatory mite Iphiseius degenerans (Berlese) (Acari: Phytoseiidae). 207 p. Ph.D. thesis. Ghent University, Ghent, Belgium.

Vantornhout, I., H. Minnaert, L. Tirry, and P. De Clercq. 2005. Influence of diet on life table parameters of Iphiseius degenerans (Acari: Phytoseiidae). Exp. Appl. Acarol. 35:183-195.

Yang, T., and H. Chi. 2006. Life tables and development of Bemisia argentifolii (Homoptera: Aleyrodidae) at different temperatures. J. Econ. Entomol. 99(3):691698.

Yu, J., H. Chi, and B. Chen. 2005. Life table and predation of Lemnia biplagiata (Coleoptera: Coccinellidae) fed on Aphis gossypii (Homoptera: Aphididae) with a proof on relationship among gross reproduction rate, net reproduction rate, and preadult survivorship. Ann. Entomol. Soc. Am. 98(4):475-482.

Zhu-Salzman, K., D.S. Luthe, and G.W. Felton. 2008. Arthropod-inducible proteins: Broad spectrum defenses against multiple herbivores. Plant Physiol. 146:852-858. 


\title{
KINETIC STUDY OF CONVECTIVE DRYING OF BLUEBERRY VARIETY O’NEIL (Vaccinium corymbosum L.)
}

\author{
A. Vega-Gálvez ${ }^{*}$, R. Lemus-Mondaca ${ }^{1}$, C. Tello-Ireland ${ }^{1}$, M. Miranda ${ }^{1}$, and F. Yagnam ${ }^{1}$
}

\begin{abstract}
The aim of this research was to study and to model the drying kinetics of the blueberry (Vaccinium corymbosum L.) at three temperatures $\left(60,70\right.$ and $\left.80^{\circ} \mathrm{C}\right)$ with an airflow of $2.0 \pm 0.2 \mathrm{~m} \mathrm{~s}^{-1}$. Modeling of the desorption isotherm was carried out with the GAB (Guggenheim, Anderson and de Boer) equation, showing a good fit to experimental moisture data, giving as a result a monolayer moisture level of $0.084 \mathrm{~g}_{\text {water }} \mathrm{g}^{-1} \mathrm{dm}$. Newton, Henderson-Pabis, Page, Modified Page and Logarithmic mathematical models were applied in the study and in the modeling of the drying kinetics of this fruit. Kinetic parameters $k$ of each model showed dependence on temperature, and were evaluated by an Arrhenius-type equation, with an activation energy of between 36.2 and $54.5 \mathrm{~kJ} \mathrm{~mol}^{-1}$. Logarithmic and Modified Page models gave the best fits for each drying curve, based on the statistical test determination coefficient, sum square error, root mean sum errors and Chi-square. In consequence, both models are excellent tools for estimating the drying time of this product.
\end{abstract}

Key words: blueberry, GAB, drying, modeling, statistical tests.

\section{INTRODUCTION}

The blueberry variety O'Neil belongs to the genus Vaccinium, of the family Ericaceae, native of North America. It is in the product grouping of berries that includes strawberry, blackberry, raspberry, and others (USHBC, 2007). It was introduced in Chile in 1990 with very good adaptive results, with the result that Chile is now considered as the main producing country of this product in the Southern Hemisphere and the third largest producer worldwide. Of the total production, 85 to $90 \%$ is exported, mainly as fresh-cooled, and a small amount is shipped frozen (Chilealimentos, 2007). The production that does not meet whole-berry quality standards is generally converted to clarified and/or concentrated juice, and other technological alternatives are being explored in order to successfully market second quality material, including convection drying with previous pretreatment (osmo-drying, high pressure drying, etc.).

Blueberries are almost spherical, depending on the species and cultivation conditions, and between 0.7 and $1.5 \mathrm{~cm}$ in diameter, with a dark blue color. They contain up to 100 very small seeds in a central core (Stückrath

${ }^{1}$ Universidad de La Serena, Departamento de Ingeniería de Alimentos, Av. Raúl Bitrán s/n. Box 599, La Serena, Chile.

"Corresponding author (avegag@userena.cl).

Received: 04 January 2008.

Accepted: 14 April 2008. and Petzold, 2007). In Chile, blueberries mature between December and late January, depending on the cultivation zone, and extending over a period of 4 to $5 \mathrm{wk}$. These berries are a rich source of antioxidant phytonutrients, which are believed to be associated with the antioxidant activity of anthocyanin pigments, flavonoids, and other phenolic compounds containing about three times the total phenolic compounds found in other berries (Skrede et al., 2000). Blueberries have become very popular with consumers because of the research findings that associate their consumption with improvements in human health (Nindo et al., 2007). However, seasonality, market accessibility and costs commonly limit the consumption of fresh fruits and vegetables, so dehydrated products are preferred over fresh products for their convenience, availability and shelf life (Azzouz et al., 2002).

Hot air drying is one of most widely used methods for food preservation. The advantage of dehydrated foods is that decreased moisture content reduces thermodynamic water activity, thus preventing the growth of microorganisms that cause spoilage reactions (Babalis and Belessiotis, 2004). The optimization of dehydration processes in the agro-food industry has led to choosing the technological variables involved in the process itself. Good experimental designs, along with statistical programs, help to obtain a higher yield from the operational and capital points of view. This must be done considering a product of the highest quality, depending on the present variables, 
one of the most important being the time of the drying process. Prior to the study of the drying of any food, it is necessary to recognize and evaluate the moisture sorption isotherms, as these mathematically describe the relation between the water activity and the equilibrium moisture content of the product under study (Vega-Gálvez et al., 2008). The use of mathematical equations is necessary for the simulation of the kinetics of matter transfer (water) that occurs during this unit operation (Vega et al., 2007). There are several empirical equations used to simulate the drying process that are exceptionally practical for the study, the modeling of kinetics and the process optimization, as well as for dryer design (Senadeera et al., 2003). Notably among these equations are those proposed by Newton, Henderson-Pabis, Page and Modified Page, etc. (Doymaz, 2004; Akpinar and Bicer, 2006).

The aim of the present study was to determine and model the drying kinetics and desorption isotherm of the blueberry variety O'Neil, using mathematical equations for both phenomena, and to evaluate the influence of drying air temperature on the kinetic parameters.

\section{MATERIALS AND METHODS}

\section{Raw material and proximate analysis}

Blueberries of the variety O'Neil (Vaccinium corymbosum L.) were cultivated and purchased in the province of Salamanca, Chile. Samples were selected to provide a homogeneous group, based on their date of harvest, color, size, and freshness according to visual analysis. The moisture content was determined according to AOAC methodology $\mathrm{N}^{\circ} 934.06$ (AOAC, 1990), using a vacuum oven (Gallenkamp, OVL570, Leicester, UK) at $70{ }^{\circ} \mathrm{C}$ for $72 \mathrm{~h}$, and an analytical balance (CHYO, Jex120, Kyoto, Japan) with an accuracy of \pm 0.0001 g. Crude protein content was determined using the Kjeldahl method with a conversion factor of 6.25. Lipid content was analyzed gravimetrically following Soxhlet extraction. Crude fiber was estimated by acid/alkaline hydrolysis of insoluble residue. Crude ash was estimated by incineration in a muffle furnace at $550{ }^{\circ} \mathrm{C}$. Acidity was determined by the adapted AOAC methodology $\mathrm{N}^{\circ}$ 942.15A (AOAC, 1990), $\mathrm{pH}$ was measured using a potentiometer (Extech Instruments, Microcomputer $\mathrm{pH}$ Vision 246072, Waltham, Massachusetts, USA), and sugar content was measured using an Abbe refractometer (ATAGO, 1-T, Tokyo, Japan). All the analyses were made in triplicate and expressed in $\mathrm{g}_{100 \mathrm{~g}^{-1} \text { sample. }}$

\section{Isotherm experiments}

Desorption isotherms were measured at $60{ }^{\circ} \mathrm{C}$. A known mass of sample (in triplicate) was allowed to come to equilibrium with the atmosphere (relative humidity) inside a hermetically sealed flask, which contained a glass dish with a saturated salt solution of known water activity. This standard gravimetric method was recommended by The European Cooperative Project COST 90, which deals with the physical properties of foods (Spiess and Wolf, 1983). The weight of the samples was taken every 15 days until reaching constant weight (equilibrium condition). The salts used to obtain a range of water activity of 0.10 to 0.95 included $\mathrm{LiCl}, \mathrm{KC}_{2} \mathrm{H}_{3} \mathrm{O}_{2}, \mathrm{MgCl}_{2}, \mathrm{~K}_{2} \mathrm{CO}_{3}, \mathrm{NaNO}_{2}$, KI, $\mathrm{NaCl}$ and $\mathrm{KNO}_{2}$ (Lim et al., 1995). Thymol was added separately in a Petri dish to the recipients containing saturated salt solutions with a relative humidity higher than $75 \%$ in order to avoid microbial growth, especially mould (Vega et al., 2007). Once equilibrium was reached, the moisture content of the samples was determined in triplicate.

The relationship between equilibrium moisture content and water activity of blueberries was expressed by the equation proposed by Guggenheim, Anderson and de Boer, commonly termed GAB (Equation [1], Quirijns et al., 2005; Blahovec and Yanniotis, 2008). GAB is commonly used in moisture sorption experiments in different foods, because of its important parameters and physiochemical description, as monolayer moisture $\left(\mathrm{X}_{\mathrm{m}}\right)$ and the parameters $\mathrm{C}_{\mathrm{o}}$ and $\mathrm{K}_{\mathrm{o}}$ (Yu et al., 1999; Timmermann et al., 2001). These parameters were obtained by nonlinear regression analysis, using the EXCEL ${ }^{\circledR}$ program of Microsoft ${ }^{\circledR}$ Windows ${ }^{\circledast}$ XP (Redmond, Washington, USA).

The criteria to evaluate the fit quality of GAB model were the statisticals determination coefficient $\left(\mathrm{r}^{2}\right)$ and mean percent square error $(\% \mathrm{E})$ (Equation [2]) (Vega et al., 2007), where $X_{\text {we }}$ is the equilibrium moisture content (g water $\mathrm{g}^{-1} \mathrm{dm}$ ), $\mathrm{a}_{\mathrm{w}}$ is the water activity (dimensionless), $\mathrm{X}_{\mathrm{m}}$ monolayer moisture (g water $\mathrm{g}^{-1} \mathrm{dm}$ ), $\mathrm{C}_{\mathrm{o}}$ and $\mathrm{K}_{\mathrm{o}}$ are constants of GAB model (dimensionless), $\mathrm{X}_{\mathrm{ei}}$ is the experimental moisture content ( $\mathrm{g}$ water $\mathrm{g}^{-1} \mathrm{dm}$ ), $\mathrm{X}_{\mathrm{ci}}$ is the calculated moisture content ( $\mathrm{g}$ water $\mathrm{g}^{-1} \mathrm{dm}$ ), $\mathrm{N}$ is the number of data values and $i$ is the number of terms.

$$
\begin{gathered}
X_{w e}=\frac{X_{m} \cdot C_{o} \cdot K_{o}}{\left(1-K_{o} \cdot a_{w}\right)\left(1+\left(C_{o}-\mathrm{l}\right) K_{o} \cdot a_{w}\right)} \\
\% E=\frac{100}{\mathrm{~N}} \cdot \sum_{j=1}^{N} \frac{\left|X_{e i}-X_{e i}\right|}{X_{e i}}
\end{gathered}
$$

\section{Drying experiments}

The drying experiment was carried out using a convective dryer designed and built in the Faculty of Engineering of Universidad de La Serena (Figure 1), La Serena. Three temperatures were used in the study of the drying kinetics $\left(60,70\right.$ and $\left.80{ }^{\circ} \mathrm{C}\right)$. Drying air velocity 


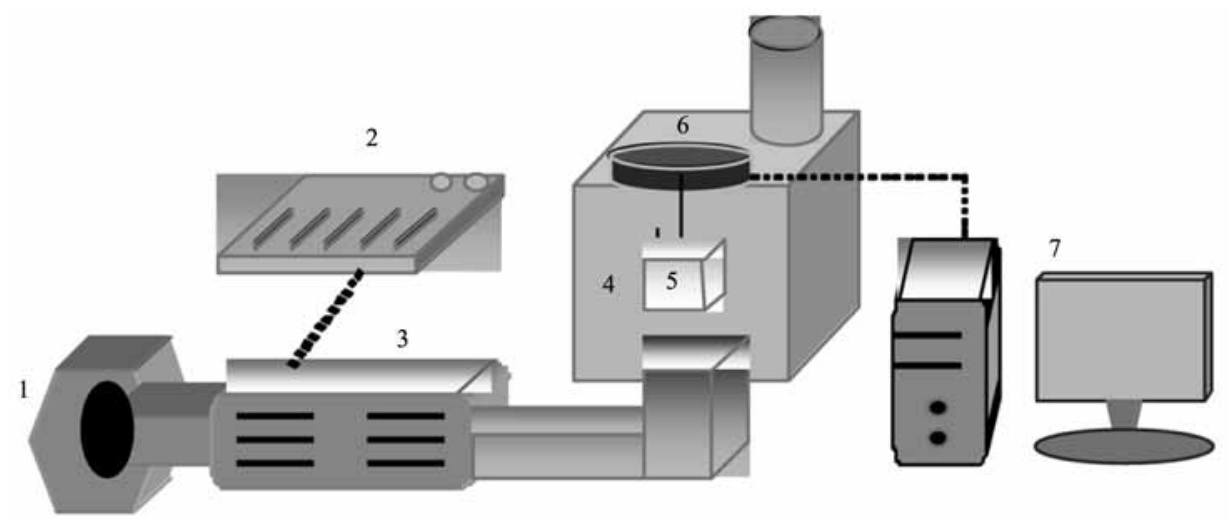

1 Ventilator. 2 Control panel. 3 Air heating section. 4 Oven. 5 Sample. 6 Digital balance and interface system. 7 PC.

Figure 1. Schematic diagram of drying equipment.

was held constant at $2.0 \pm 0.2 \mathrm{~m} \mathrm{~s}^{-1}$ and measured with an omnidirectional anemometer (Extech Instrument Inc., 451112, Waltham, Massachusetts, USA). The inlet relative humidity was $62.0 \pm 5.2 \%$, measured by an ambient digital hygro-thermometer (Extech Instrument Inc., 445703, Waltham, Massachusetts, USA). All the drying experiments were carried out in triplicate, using a sample mass of $100.0 \pm 2.4 \mathrm{~g}$ and the charge density was $8.5 \pm 0.3 \mathrm{~kg} \mathrm{~m}^{-2}$. Prior to the drying of the samples, they were pretreated with a Pectine ${ }^{\circledR}$ solution, concentration $0.8 \%$ (Novo Nordisk Ferment Ltd., Flawil, Switzerland). The mass was measured on an analytical balance (Ohaus, SP402, New Jersey, USA) with an accuracy of $\pm 0.01 \mathrm{~g}$ at defined time intervals, connected by a interface system (Ohaus, RS232, Pine Brook, New Jersey, USA) to a PC, which recorded and stored the data. The experiments were finished at the point of reaching constant weight (equilibrium condition). The dried samples were packaged in polypropylene bags.

\section{Modeling of drying kinetics}

Drying kinetic was modeled by means of five empirical equations widely used in most organic and biological materials. These equations use a relationship termed moisture ratio (MR) as a dependant variable (Equation [3]), relating the gradient of the sample moisture in real time $\left(\mathrm{X}_{\mathrm{wt}}\right)$ with initial moisture $\left(\mathrm{X}_{\mathrm{wo}}\right)$ and equilibrium moisture $\left(X_{\text {we }}\right)$ (Babalis and Belessiotis, 2004). These are Newton (Equation [4]), Henderson-Pabis (Equation [5]), Page (Equation [6]), Modified Page (Equation [7]) and Logarithmic (Equation [8]). In this research, the shrinkage and external resistance were assumed as negligible. Where $k$ is kinetic parameters $\left(\mathrm{min}^{-1}\right), n$ and $a$ are empirical parameters (dimensionless) and $t$ is drying time (min).

$$
\begin{array}{lr}
M R=\left(X_{w t}-X_{w e}\right) /\left(X_{w o}-X_{w e}\right) & \text { Akpinar and Bicer (2006) [3] } \\
M R=\exp (-k t) & \text { Vega et al. (2007) [4] } \\
M R=\mathrm{n} \cdot \exp (-k t) & \text { Vega-Gálvez et al. (2008) [5] } \\
M R=\exp \left(-k t^{n}\right) & \text { Doymaz (2007) [6] } \\
M R=\exp \left(-(k t)^{n}\right) & \text { Menges and Ertekin (2006) [7] } \\
M R=\mathrm{n} \cdot \exp (-k t)+a & \text { Akpinar and Bicer (2006) [8] }
\end{array}
$$

In order to observe any influence of drying temperature on the kinetic parameters $k$, an Arrhenius-type equation was applied (Equation [9]), from which the activation energy is obtained $\left(E_{a} \mathrm{~kJ} \mathrm{~mol}^{-1}\right)$, which shows sensitivity of the parameter to temperature (Simal et al., 1996; Simal et al., 2005). Activation energy can be determined by the graphic representation between $\ln k$ versus $\mathrm{T}^{-1}(\mathrm{~K})$.

$$
k=k_{O} \cdot \exp \left(-E_{a} / R T\right)
$$

\section{Statistical analysis of the models}

The fit quality of the experimental data to the desorption isotherm and all the models proposed for drying kinetics were evaluated using the determination coefficient $\left(\mathrm{r}^{2}\right)$, sum squared errors (SSE, Equation [10]), root mean sum errors (RMSE, Equation [11]) and Chi-square $\left(\chi^{2}\right.$, Equation [12]) statisticals. The values closest to 1.0 for $\mathrm{r}^{2}$, and those closest to zero for SSE, RMSE and $\chi^{2}$, are commonly considered as optimum criteria to evaluate the fit quality of the models used (Doymaz, 2004; Akpinar and Bicer, 2006; Doymaz, 2007; Vega et al., 2007). The statistical evaluations were made on the predictions of 
equilibrium moisture content by the desorption isotherm, as well as on the drying kinetics. Where $\mathrm{MR}_{\mathrm{ej}}$ is the experimental moisture ratio (dimensionless), $\mathrm{MR}_{\mathrm{cj}}$ is the calculated moisture ratio (dimensionless), $\mathrm{z}$ is the number of constants and $\mathrm{j}$ is the number of terms.

$$
\begin{gathered}
S S E=\frac{\mathrm{l}}{\mathrm{N}} \cdot \sum_{j=1}^{N}\left(M R_{e j}-M R_{c j}\right)^{2} \quad \text { Simal et al. (2005) [10] } \\
R M S E=\left[\frac{1}{\mathrm{~N}} \sum_{j=1}^{N}\left(M R_{c j}-M R_{e j}\right)^{2}\right]^{1 / 2} \\
\begin{array}{r}
\text { Togrul and } \\
\text { Pehlivan (2003) }
\end{array} \\
X^{2}=\frac{\sum_{j=1}^{N}\left(M R_{e j}-M R_{c j}\right)^{2}}{\mathrm{~N}-\mathrm{z}} \quad \text { Doymaz (2007) [12] }
\end{gathered}
$$

\section{RESULTS AND DISCUSSION}

\section{Experimental analysis and desorption isotherm}

The proximate analysis of blueberry variety O'Neil gave an initial moisture content of $78.13 \pm 0.05 \mathrm{~g} 100$ $\mathrm{g}^{-1}$ sample $\left(\mathrm{a}_{\mathrm{w}}=0.99 \pm 0.01\right)$; crude protein (nitrogen $\mathrm{x}$

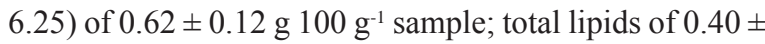

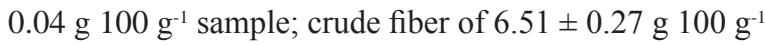

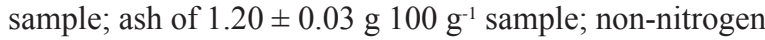

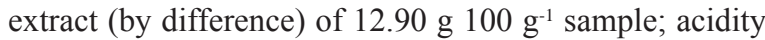
of $2.21 \pm 0.12 \%$ (monohydrated citric acid); $\mathrm{pH} 2.72 \pm$ 0.09 , and soluble solids of $15.01 \pm 0.07^{\circ}$ Brix.

Figure 2 shows the experimental data of the equilibrium moisture contents of the blueberry desorption isotherm at $60{ }^{\circ} \mathrm{C}$, where equilibrium moisture content increases as water activity increases from 0.10 to 0.95 . The tendency of this isotherm could correspond to that of type II isotherms, according to Van der Waals' classification (Brunauer et al., 1938). Various authors working with other types of foods have observed this behavior (Kiranoudis et al., 1993; Timmermann et al., 2001; Kaymak-Ertekin and Gedik, 2004). The type II isotherm appears when the bonding energy between the water and the primary layer is less than that occurring among water molecules (Lomauro et al., 1985). It was observed the good fit on the experimental data obtained by $\mathrm{GAB}\left(\mathrm{r}^{2}=0.97 ; \% \mathrm{E}=\right.$ 8.64 ) for a whole range of water activity (Figure 2). The sorption parameters obtained were $\mathrm{X}_{\mathrm{m}}=0.084 \mathrm{~g}$ water $\mathrm{g}^{-1} \mathrm{dm}, \mathrm{C}_{\mathrm{o}}=13.319$, and $\mathrm{K}_{\mathrm{o}}=0.933$. Similar results of monolayer moisture have been observed in raisins, figs, plums, potatoes, onions and tomatoes with $0.212-0.087 \mathrm{~g}$ water $\mathrm{g}^{-1} \mathrm{dm}$ for $30-60{ }^{\circ} \mathrm{C}$ (Kiranoudis et al., 1993); in red and green peppers with $0.113-0.038 \mathrm{~g}^{-1}$ water $\mathrm{g}^{-1} \mathrm{dm}$ for 30 $60{ }^{\circ} \mathrm{C}$ (Kaymak-Ertekin and Sultanoglu, 2001); in grapes, apples, potatoes and apricots with 0.220-0.095 g water $\mathrm{g}^{-1} \mathrm{dm}$ for $30-60{ }^{\circ} \mathrm{C}$ (Kaymak-Ertekin and Gedik, 2004). Monolayer moisture $\left(\mathrm{X}_{\mathrm{m}}\right)$ is an important parameter since it has a physicochemical behavior that represents the first layer of water molecules, which can thermodynamically interact with other food compounds (Lim et al., 1995; Yu et al., 1999).

\section{Behavior of drying curves}

For all drying experiments, an average outlet temperature of drying air of $60.0 \pm 4.2{ }^{\circ} \mathrm{C}$ was obtained. For this reason, the desorption isotherm modeled by the GAB equation was used to estimate the equilibrium moisture content to each temperature, with $X_{w e}=0.031 \mathrm{~g}$

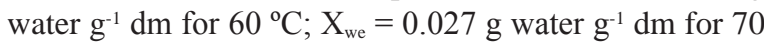
${ }^{\circ} \mathrm{C}$ and $\mathrm{X}_{\text {we }}=0.026 \mathrm{~g}$ water $\mathrm{g}^{-1} \mathrm{dm}$ for $80^{\circ} \mathrm{C}$. In general, for all drying experiments, the equilibrium moisture content was lower than $18 \%$, which gives product stability from the commercial and hygienic points of view (Karathanos and Belessiotis, 1999). Increasing the drying temperature decreased drying time (Figure 3). The shortest time (500 min) was obtained at $80{ }^{\circ} \mathrm{C}$ in comparison to drying at 70 and $60{ }^{\circ} \mathrm{C}$, which required times of 800 and 1400 min, respectively. Other research on fruit and vegetable drying present the same tendency and behavior of the drying curves, such as Azzouz et al. (2002); Krokida et al. (2003); Babalis and Belessiotis (2004); Simal et al. (2005); Akpinar and Bicer (2006); Vega et al. (2007); and Doymaz (2007).

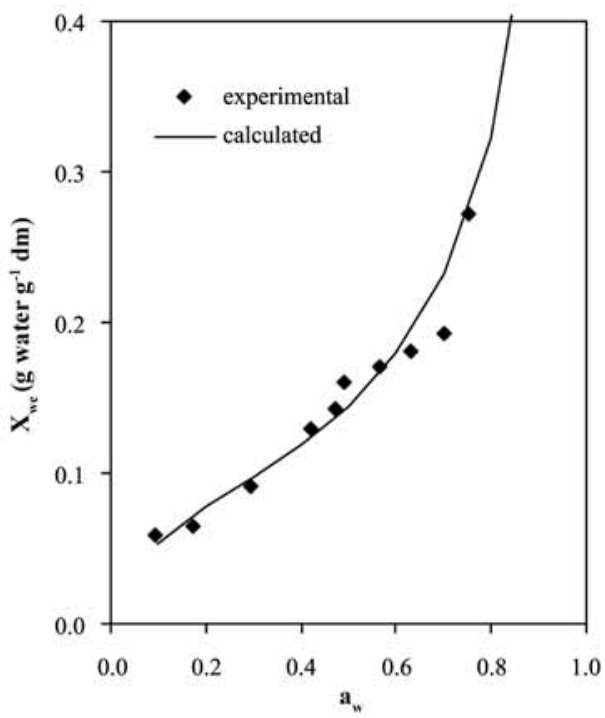

$\mathrm{a}_{\mathrm{w}}$ : water activity (dimensionless). $\mathrm{X}_{\mathrm{we}}$ : equilibrium moisture content.

Figure 2. Desorption isotherm of blueberries modeled by the $\mathrm{GAB}$ equation at $60^{\circ} \mathrm{C}$. 


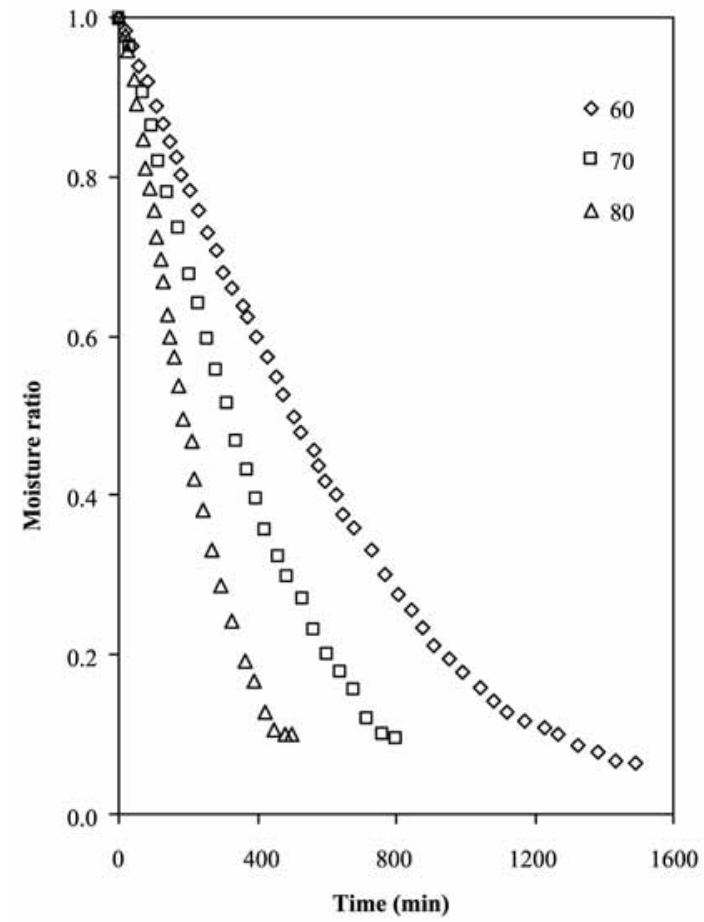

Figure 3. Drying curves for blueberries at different drying temperatures $\left(60,70\right.$, and $\left.80^{\circ} \mathrm{C}\right)$.

\section{Modeling of the drying process}

Drying curves (Figure 3) showed a clear exponential tendency and only a falling rate period was observed, which is very common in fruit and vegetable drying processes (Togrul and Pehlivan, 2003; Kingsly et al., 2007). Under these conditions, the use of the five empirical models is suggested, as mentioned before. Table 1 shows the values for the kinetic parameters $k$ of the five models for each drying temperature evaluated. A value of $p<0.05$ for a confidence level of $95 \%$ was obtained by ANOVA, using Statgraphics Plus ${ }^{\circledR} 5.1$ software (Statistical Graphics Corp., Herndon, Virginia, USA), suggesting there are statistically significant differences among these kinetic parameters with respect to temperature. In order to prove the dependence of these parameters on the drying temperature, an Arrheniustype equation (Figure 4) was applied, showing $\mathrm{r}^{2} \geq 0.95$. The activation energy obtained for each kinetic parameter was $51.05 \mathrm{~kJ} \mathrm{~mol}^{-1}$ (Newton), $54.45 \mathrm{~kJ} \mathrm{~mol}^{-1}$ (Henderson-

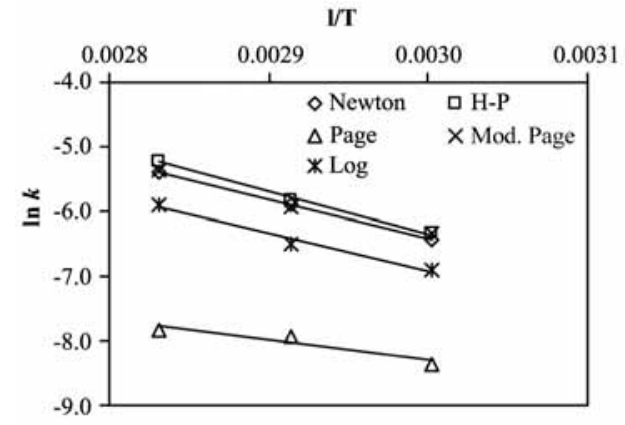

Figure 4. Relationship between the kinetic parameters $k$ versus the inverse of temperature $(K)$ modeled by means of five empirical equations: Newton, HendersonPabis (H-P), Page, Modified Page (Mod. Page) and Logarithmic (Log).

Pabis), $36.20 \mathrm{~kJ}^{-1}$ (Page), $46.39 \mathrm{~kJ} \mathrm{~mol}^{-1}$ (Modified Page), and $48.34 \mathrm{~kJ} \mathrm{~mol}^{-1}$ (Logarithmic). Several authors have presented very similar activation energy values, including Azzouz et al. (2002); Babalis and Belessiotis (2004); Simal et al. (2005); Akpinar and Bicer (2006), Doymaz (2007) and Vega et al. (2007). Kinetic parameter $k\left(\mathrm{~min}^{-1}\right)$ also showed a clear tendency of increasing as the working temperature increased (Table 1). Similar results were obtained by Karathanos and Belessiotis (1999) working with figs, plums and raisins; Togrul and Pehlivan (2003) with apricots; and Akpinar and Bicer (2006) in strawberry drying.

The empirical parameters $n$ of Henderson-Pabis, Page, Modified Page and Logarithmic, as well as the empirical parameter $a$, did not show statistically significant differences ( $\mathrm{p}$ value $>0.05$ ), suggesting they probably depend more on the characteristics of the tissue and the drying air flow (Akpinar and Bicer, 2006; Menges and Ertekin, 2006). Azzouz et al. (2002), working with grapes, concluded that the parameter $n$ was in function of air flow rate and that the parameter $k$ of Page depended on the temperature and the initial moisture of the product. Karathanos and Belessiotis (1999), working on skinned and non-skinned fruit dehydration, proposed that parameter $n$ increased with the existence of the outer skin depending on its thickness and the kind of product to be dried.

Table 1. Values of kinetic parameters $k\left(x^{10} 0^{-1} \mathrm{~min}^{-1}\right)$ for each drying curve.

\begin{tabular}{cccccc}
\hline $\mathbf{T}^{\mathbf{}} \mathbf{C}$ & Newton & Henderson-Pabis & Page & Modified Page & Logarithmic \\
\hline 60 & $0.0160 \pm 0.0002 \mathrm{a}$ & $0.0177 \pm 0.0005 \mathrm{a}$ & $0.0240 \pm 0.0007 \mathrm{a}$ & $0.0178 \pm 0.0001 \mathrm{a}$ & $0.0101 \pm 0.0005 \mathrm{a}$ \\
70 & $0.0273 \pm 0.0003 \mathrm{a}$ & $0.0300 \pm 0.0005 \mathrm{a}$ & $0.0390 \pm 0.0016 \mathrm{~b}$ & $0.0269 \pm 0.0002 \mathrm{~b}$ & $0.0152 \pm 0.0002 \mathrm{~b}$ \\
80 & $0.0470 \pm 0.0005 \mathrm{~b}$ & $0.0557 \pm 0.0018 \mathrm{~b}$ & $0.0420 \pm 0.0003 \mathrm{c}$ & $0.0468 \pm 0.0011 \mathrm{c}$ & $0.0273 \pm 0.0003 \mathrm{c}$ \\
\hline
\end{tabular}

Data are expressed as mean \pm standard deviation of three replications. Values in the same column with the same letter are not statistically different at a confidence level of $95 \%$. 


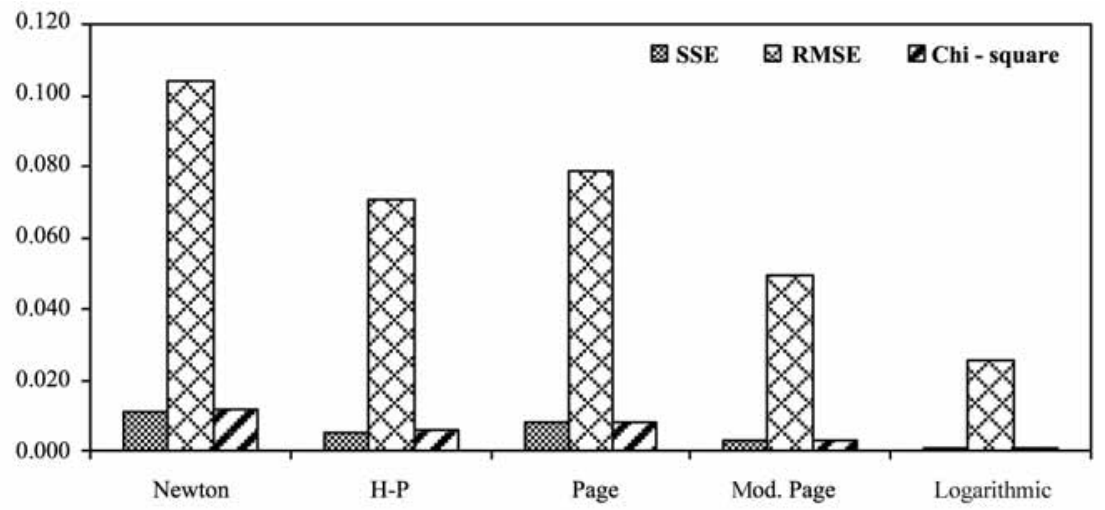

Newton, Henderson-Pabis (H-P); Page, Modified Page (Mod. Page); and Logarithmic (Log); SSE: sum squared errors; RMSE: root mean sum errors.

Figure 5. Graphic representation of the statistic test for each model.

\section{Statistical analyses of models}

Logarithmic and Modified Page models provided good fits to the experimental data for a whole drying process (Figure 5). All the models presented high values for the determination coefficient $\left(\mathrm{r}^{2} \geq 0.95\right)$ at three temperatures $\left(60,70\right.$ and $\left.80^{\circ} \mathrm{C}\right)$. Furthermore, the lowest SSE, RMSE and $\chi^{2}$ values were selected as optimal criteria in order to evaluate the fitting quality of the five models proposed. A good fit was observed based on this evaluation, since low SSE $(<0.0027)$, RMSE $(<0.0495)$ and $\chi^{2}(<0.0029)$ values were obtained by Logarithmic and Modified Page models; followed by Henderson-Pabis, Page and Newton. Other authors have also obtained good results when applying these models in drying kinetics of other food and foodstuff (Krokida et al., 2003; Togrul and Pehlivan,
2003; Doymaz, 2004; Simal et al., 2005; Menges and Ertekin, 2006; Doymaz, 2007).

Figure 6 shows the experimental and calculated values for the drying curves represented by MR vs. time for the two best models found in this investigation (Logarithmic and Modified Page). Both models gave similar results over the whole drying process from the beginning to the end, considering the middle stage of the drying process. The good estimations obtained by these two models represent results that are not usually given by many models, since the middle stage of the drying process is the segment where most of the water is removed from the food. Thus, a good simulation is required for the estimation of the optimum drying time. a)

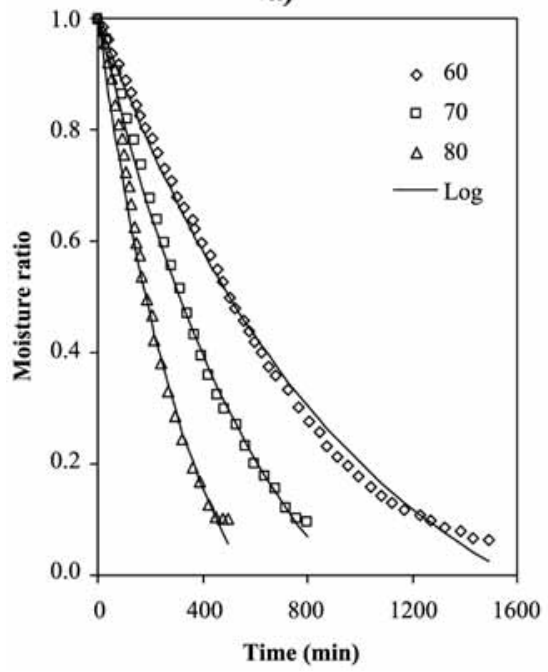

b)

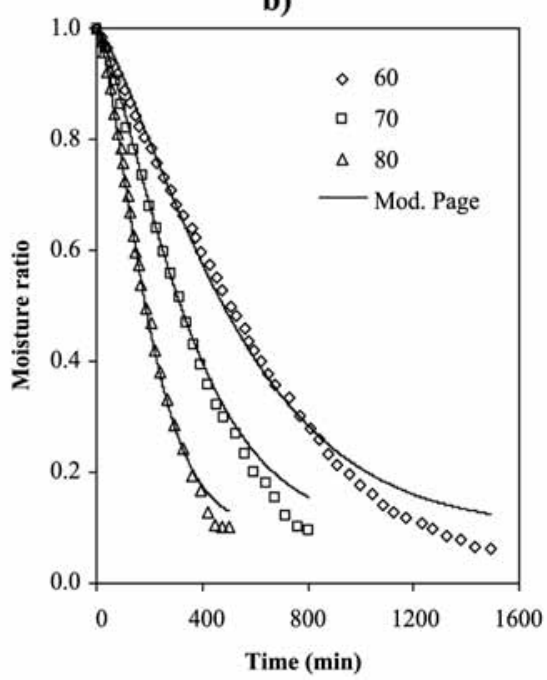

Figure 6. Experimental and calculated drying curves for a) Logarithmic (Log) and b) Modified Page (Mod. Page) at the different working temperatures $\left({ }^{\circ} \mathrm{C}\right)$. 


\section{CONCLUSIONS}

The results of this study showed that the GAB model provided a good fit to the experimental data of desorption isotherm, with $8.64 \% \mathrm{E}$ and $\mathrm{r}^{2}=0.97$. Drying of blueberries presents a clear dependence on drying air temperature, showing only a falling rate period, and reaching an average equilibrium moisture close to $0.03 \mathrm{~g}$ water $\mathrm{g}^{-1} \mathrm{dm}$. All models used to describe the dehydration kinetics were useful. Nevertheless, Logarithmic and Modified Page models gave the best fit quality to drying experimental data at the three temperatures used, based on the statistical tests used for evaluation. All the kinetic parameters $k$ were dependant on the drying temperature, giving an activation energy of 48.34 and $46.39 \mathrm{~kJ} \mathrm{~mol}^{-1}$ for Logarithmic and Modified Page, respectively. In consequence, both models are excellent tools for estimating the drying time of this product.

\section{ACKNOWLEDGEMENTS}

The authors wish to thank the Research Office of the Universidad de La Serena (DIULS) and Ricardo León Alcarraz of Agrícola Estero Camisas for the financial support given to the publication of this research.

\section{RESUMEN}

Estudio de la cinética del secado convectivo de arándano variedad O’Neil (Vaccinium corymbosum L.). El objetivo de esta investigación fue estudiar y modelar la cinética de secado del arándano (Vaccinium corymbosum L.) a tres temperaturas $\left(60,70\right.$ y $\left.80^{\circ} \mathrm{C}\right)$ con un flujo de aire de 2,0 $\pm 0,2 \mathrm{~m} \mathrm{~s}^{-1}$. El modelado de la isoterma de desorción se llevó a cabo con la ecuación de GAB (Guggenheim, Anderson y de Boer), mostrando un buen ajuste sobre los datos experimentales de humedad, dando como resultado una humedad de la monocapa de 0,084 g de agua $\mathrm{g}^{-1}$ ms. Se aplicaron los modelos matemáticos de Newton, Henderson-Pabis, Page, Page modificado y Logarítmico para el modelado de la cinética de secado de esta fruta. Los parámetros cinéticos $k$ de cada modelo presentaron dependencia con la temperatura, evaluadas por una ecuación de tipo Arrhenius, con una energía de activación entre 36,2-54,5 kJ mol-1. Los modelos Logarítmico y Page modificado obtuvieron el mejor ajuste para cada curva de secado, basado en las pruebas estadísticas como coeficiente de determinación, suma de errores cuadrados, raíz media de los errores cuadrados y Chi-cuadrado. En consecuencia, ambos modelos son excelentes herramientas para estimar el tiempo de secado de este producto.

Palabras clave: arándanos, GAB, secado, modelado, pruebas estadísticas.

\section{LITERATURE CITED}

AOAC. 1990. Official method of analysis. $15^{\text {th }}$ ed. Association of Official Analytical Chemists $\left(\mathrm{N}^{\circ}\right.$ 934.06), Washington D.C., USA.

Akpinar, E.K., and Y. Bicer. 2006. Mathematical modeling experimental study on thin layer drying of strawberry. Int. J. Food Eng. 2:5.

Azzouz, S., A. Guizani, W. Jomaa, and A. Belghith. 2002. Moisture diffusivity drying kinetic equation of convective drying of grapes. J. Food Eng. 55:323-330.

Babalis, S.J., and V.G. Belessiotis. 2004. Influence of the drying conditions on the drying constants moisture diffusivity during the thin-layer drying of figs. J. Food Eng. 65:449-458.

Blahovec, J., and S. Yanniotis. 2008. GAB generalized equation for sorption phenomena. Food Bioprocess Technol. 1:82-90.

Brunauer, S., P. Emmett, and E. Teller. 1938. Adsorption of gases in multimolecular layers. J. Am. Chem. Soc. 60:309-319.

Chilealimentos. 2007. Asociación de empresas de alimentos de Chile. Productos y empresas. Ventajas de Chile. Available at http://www.chilealimentos.com (Accessed 10 June).

Doymaz, I. 2004. Drying kinetics of white mulberry. J. Food Eng. 61:341-346.

Doymaz, I. 2007. Influence of pretreatment solution on the drying of sour cherry. J. Food Eng. 78:591-596.

Karathanos, V.T., and V.G. Belessiotis. 1999. Application of a thin-layer equation to drying data of fresh semidried fruits. J. Agric. Eng. Res. 74:355-361.

Kaymak-Ertekin, F., and A. Gedik. 2004. Sorption isotherms and isosteric heat of sorption for grapes, apricots, apples and potatoes. LWT - Food Sci. Technol. 37:429-438.

Kaymak-Ertekin, F., and M. Sultanoglu. 2001. Moisture sorption isotherm characteristics of peppers. J. Food Eng. 47:225-231.

Kingsly, R.P., R.K. Goyal, M.R. Manikantan, and S.M. Ilyas. 2007. Effects of pretreatments drying air temperature on drying behaviour of peach slice. Int. J. Food Sci. Technol. 42:65-69.

Kiranoudis, C.T., Z.B. Maroulis, E. Tsami, and D. MarinoKouris. 1993. Equilibrium moisture content and heat of desorption of some vegetables. J. Food Eng. 20:5574.

Krokida, M.K., V.T. Karathanos, Z.B. Maroulis, and D. Marinos-Kouris. 2003. Drying kinetics of some vegetables. J. Food Eng. 59:391-403.

Lim, L.T., J. Tang, and J. He. 1995. Moisture sorption characteristics of freeze dried blueberries. J. Food Sci. 60:810-814. 
Lomauro, C.J., A.S. Bakshi, and T.P. Labuza. 1985. Evaluation of food moisture sorption isotherm equations. Part I: fruit, vegetable and meat products. LWT - Food Sci. Technol. 18:111-117.

Menges, H.O., and C. Ertekin. 2006. Mathematical modeling of thin layer drying of golden apples. J. Food Eng. 77:119-125.

Nindo, C.I., J. Tanga, J.R. Powersb, and P.S. Takhar. 2007. Rheological properties of blueberry puree for processing applications. LWT - Food Sci. Technol. 40:292-299.

Quirijns, E.J., A.J.B. van Boxtel, W.K.P. van Loon, and G. van Straten. 2005. Sorption isotherms, GAB parameters and isosteric heat of sorption. J. Sci. Food Agric. 85:1805-1814.

Senadeera, W., B.R. Bhari, G. Young, and B. Wijesinghe. 2003. Influence of shapes of selected vegetable material son drying kinetics during fluidized bed drying. J. Food Eng. 58:277-283.

Simal, S., A. Femenia, M.C. Garau, and C. Roselló. 2005. Use of exponential, Page's and difusional models to simulate the drying kinetics of kiwi fruits. J. Food Eng. 66:323-328.

Simal, S., A. Mulet, P.J. Catalá, J. Cañellas, and C. Roselló. 1996. Moving boundary model for simulating moisture movement in grapes. J. Food Sci. 61:157-160.

Spiess, W., and W. Wolf. 1983. The results of the COST 90 project on water activity. p. 65. Jowitt, R., F. Escher, M. Kent. B. McKenna, and M. Roques (eds.) Physical properties of foods. Elsevier Applied Science Publisher, London, England.
Skrede, G., R.E. Wrolstad, and R.W. Durst. 2000. Changes in anthocyanins and polyphenolics during juice processing of O'Neil blueberries (Vaccinium corymbosum L.) J. Food Sci. 65:357-364.

Stückrath, R., and G. Petzold. 2007. Formulación de una pasta gelificada a partir del descarte de arándanos (Vaccinium corymbosum). Inf. Tecnol. 18:53-60.

Timmermann, E.O., J. Chirife, and H.A. Iglesias. 2001. Water sorption isotherms of foods and foodstuffs: BET and GAB parameters? J. Food Eng. 48:19-31.

Togrul, I.T., and D. Pehlivan. 2003. Modeling of drying kinetics of single apricot. J. Food Eng. 58:23-32.

USHBC. 2007. Blueberries storage and processing. United States Highbush Blueberry Council, Folsom, California, USA. Available at http://www.blueberry. org/Storage\&Processing1.pdf (Accessed 21 May).

Vega-Gálvez, A., R. Lemus-Mondaca, C. Bilbao-Sainz, F. Yagnam, and A. Rojas. 2008. Mass transfer kinetics during convective drying of red pepper var. Hungarian (Capsicum annuum L.): Mathematical modeling and evaluation of kinetics parameters. J. Food Process Eng. 31:120-137.

Vega, A., A. Andrés, P. Fito, and R. Lemus. 2007. Mathematical modeling of hot-air drying kinetics of red bell pepper (var. Lamuyo). J. Food Eng. 79:14601466.

Yu, L., G. Mazza, and D.S. Jayas. 1999. Moisture sorption characteristics of freeze-dried, osmofreeze-dried, and osmo-air-dried cherries and blueberries. Am. Soc. Agric. Eng. 42:141-147. 


\title{
LOCATION AND CLASSIFICATION OF MOVING FRUITS IN REAL TIME WITH A SINGLE COLOR CAMERA
}

\author{
José F. Reyes ${ }^{*}$, and Luciano E. Chiang²
}

\begin{abstract}
Quality control of fruits to satisfy increasingly competitive food markets requires the implementation of automatic visual servo systems in fruit processing operations to cope with market challenges. A new and fast method for identifying and classifying moving fruits by processing single color images from a static camera in real time was developed and tested. Two algorithms were combined to classify and track moving fruits on image plane using representative color features. The method allows classifying the fruit by color segmentation and estimating its position on the image plane, which provides a reliable algorithm to be implemented in robotic manipulation of fruits. To evaluate the methodology an experimental real time system simulating a conveyor belt and real fruit was used. Testing of the system indicates that with natural lighting conditions and proper calibration of the system a minimum error of $2 \%$ in classification of fruits is feasible. The methodology allows for very simple implementation, and although operational results are promising, even higher accuracy may be possible if structured illumination is used.
\end{abstract}

Key words: fruit classification, color image feature, visual servo control, look-and-move.

\section{INTRODUCTION}

When it comes to fresh fruit automatic processing, real time methodologies to accomplish classification tasks are desirable to improve efficiency of fruit processing lines. Visual servo robotic manipulators are able to perform intelligent fruit manipulation based on image plane information in real time if suitable image processing algorithms are provided. Many visual servo control architectures and strategies have been analyzed and classified in the literature (Stavnitzy and Capson, 2000; Xiao and Todo, 2001; Gans et al., 2003), with a mobile camera, either mounted on the effector or in a fixed position to get visual feedback from the workspace. Control strategies can be position-based if control input is defined in terms of absolute position; or image-based if control input is defined according to changes in position of image features on the image plane. The choice of particular servoing architecture relies on aspects such as the inherent geometry of the robotic task, reliability, accuracy,

${ }^{1}$ Universidad de Concepción, Facultad de Ingeniería Agrícola, Av. Vicente Méndez 595, Chillán, Chile.

*Corresponding author (jreyes@udec.cl).

${ }^{2}$ Pontificia Universidad Católica de Chile, Facultad de Ingeniería, Av. Vicuña Mackenna 4860, Santiago, Chile. (lchiang@puc.cl).

Received: 18 March 2008.

Accepted: 16 June 2008. speed and cost. In many cases the motion of a target, for example an object on a conveyor, is most conveniently expressed in a Cartesian reference frame; therefore most systems dealing with moving objects have used positionbased methods (Taylor and Kleeman, 2004; Deng et al., 2005). One of the major applications of visual servo control for robotic manipulators in industry deals with grasping objects from a static or mobile surface, mainly to substitute manual labor in inspection, identification, selection or classification operations (Penman, 2001; Recce et al., 1998). In applications such as processing lines for fruits and vegetable selection, a monocular static camera arrangement is the simplest and most economical implementation, configured to simultaneously image the target fruits and the effector. Color image processing has been used to develop methodologies to assess the maturity levels of fruits. There are discriminator methods based on neural perceptron networks (Leemans et al., 2002) to overcome the fuzzy nature of the class membership identification. Generally, the approach is statistically based and uses a Bayesian type of discriminate analysis (Leemans et al., 2002; Blasco et al., 2003). When these methods make the conversion from red, green and blue (RGB) to hue, saturation and value (HSV) space and the classification functions are multivariable expressions. More computer processing time is required, which is undesirable for real time applications. 
In color segmentation of an image, the objective is to spatially separate regions based on similarities inside each region and differences among distinct regions. The way to undertake the segmentation of color varies from the empirical evaluation of various color spaces (Horiuchi, 2006), to modeling based on physical principles (Gheissari and Bab-Hadiashar, 2003). The primary difference between color segmentation and recognition is that the first utilizes color to separate objects without prior knowledge of the specific surfaces, while the second tries to recognize colors knowing the chromatic characteristics of the surface. Although the two problems are conceptually different; the results of the segmentation can be used in recognition. The concept of color indexing in recognition, implies the use of histograms to index objects in images (Berens et al., 2000), trying to exploit color as a useful aspect for quick detection.

\section{Theoretical considerations}

Image to space transformation. Mapping from space to image was done according to proper geometrical modeling of the visual system. Geometric correspondence between space and image is illustrated in Figure 1, along with the camera calibration rig. A point $P_{0}$ in space on the calibration rig will be considered, characterized by the coordinate vector $\boldsymbol{X}_{c}=\left[\begin{array}{lll}x_{c} & y_{c} & z_{c}\end{array}\right]^{\mathrm{T}}$ in the camera reference frame. The coordinate of $P_{0}$ with respect to the calibration rig is therefore $\boldsymbol{X}_{0}=\left[x_{0} y_{0} z_{0}\right]^{\mathrm{T}}$. Once a spatial view geometry analysis is performed (Reyes and Chiang, 2003), the position of point $P_{0}$ in camera coordinate system can be written as:

$$
\left[\begin{array}{c}
\boldsymbol{X}_{c} \\
1
\end{array}\right]=\frac{z_{c}}{d_{r}}\left\{\boldsymbol{K}^{-1}\left[\begin{array}{c}
\boldsymbol{X}_{p} \\
1
\end{array}\right]\left[\begin{array}{c}
\boldsymbol{d} \boldsymbol{x} \\
0
\end{array}\right]\right\}
$$

where: $X_{c}$ are coordinates of the space point in the camera frame; $z_{c}$ is the distance from the camera frame origin to the space point along the $Z_{c}$ axis; $d_{r}$ accounts for the radial distortion factor; $K$ is the calibration matrix of the camera; $X_{P}$ are the projected coordinates of the point on the image plane and $d x$ is the tangential distortion vector.

Color feature learning. For a $M \times N$ color image with components $(R, G, B)$, the chromaticity coordinates $(r, g, b)$ are the normalized components, which are expressed as:

$$
\begin{aligned}
& r=\frac{R}{\mathrm{R}+\mathrm{G}+\mathrm{B}} \times 225 \\
& g=\frac{G}{\mathrm{R}+\mathrm{G}+\mathrm{B}} \times 225 \\
& b=\frac{B}{\mathrm{R}+\mathrm{G}+\mathrm{B}} \times 225
\end{aligned}
$$

where $r+g+b=255$, and color can be represented in the chromaticity diagram $(r, g)$ (Vertan and Boujemaa, 2000). Given a $M \times N$ color image $f$ characterized by the normalized color components $f_{r}$ and $f_{g}$; each term of the color distribution histogram matrix $H(256 \times 256)$ can be expressed as:

$$
H(r, g)=\sum_{i=1}^{M-1} \sum_{j=1}^{N-1}\left(f_{r}(i, j)-r\right)\left(f_{g}(i, j)-g\right)
$$

with $\delta(f-c)=1$ if $f=c$ or $f=0$ if $f \neq c$. Since the ultimate goal is to recognize an object (effect or object) from the background; a differential histogram $H_{O B}$ between object histogram $H_{O}$ and background histogram $H_{\mathrm{B}}$ can be evaluated. The $H_{\mathrm{O}}$ histogram is evaluated using Equation [3] from images of objects including its background, while the $H_{\mathrm{B}}$ histogram is obtained by applying Equation [3] to images of the background while it does not contain any object. Each term of the differential histogram $\mathrm{H}_{O B}$ can then be written as:

$$
H_{O B}(r, g)=\sum_{r=0}^{255} \sum_{g=0}^{255} H_{O}(r, g)\left[1-\operatorname{sing}\left(H_{B}(r, g)\right)\right]
$$

where:

$$
\operatorname{sing}(H(r, g))=\left\{\begin{array}{l}
1 \text { if }(H(r, g)>0 \\
0 \text { if }(H(r, g)=0
\end{array}\right.
$$

The differential color histogram eliminates the color similarities between the object and the background. In order to use the information contained in the differential histogram matrix of Equation [4] for object feature extraction; a subset array $H_{M}(3 \times n)$, defined as the main components matrix (MCM) will contain the $n$ non-zero values of $H_{O B}$. Each column of $H_{M}$ will contain, in the first row, the color frequencies (number of pixels of given color components), and the corresponding color components $r$ and $g$ in the second and third rows respectively. This matrix is organized to have the values of frequencies in descending order in the first row, decreasing to the lowest non-zero value. Consequently, the second and third row contain the $r$ and $g$ components corresponding to each non-zero frequency. Therefore, the MCM for an object may be expressed as:

$$
\boldsymbol{H}_{M}=\left[\begin{array}{l}
\boldsymbol{n f} \\
\boldsymbol{r} \\
\boldsymbol{g}
\end{array}\right]
$$

where: $n f$ is a file vector containing the color non-zero frequencies in descending order of magnitude; $r$ and $g$ are file vectors containing the $(r, g)$ pairs corresponding to each color frequency of the vector $n f$. 
$O_{c}$

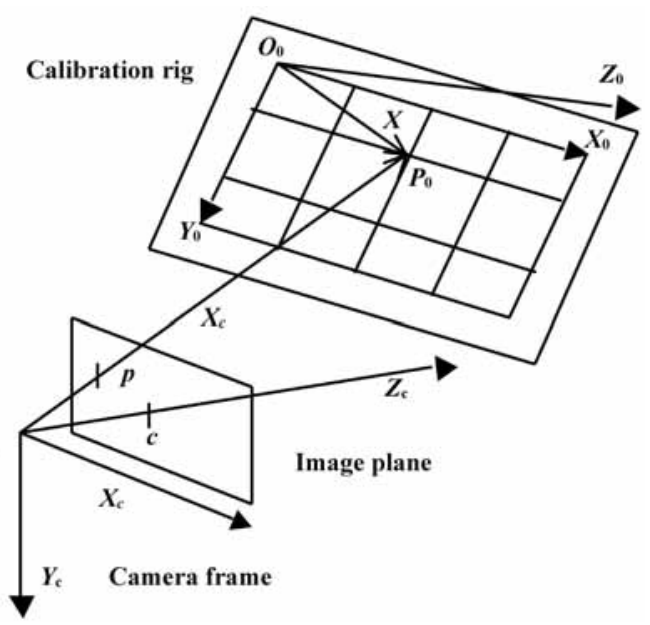

Figure 1. Image and space correspondence.

The objective of this research was to develop a robust and simple methodology that combines color feature extraction algorithms for tracking and classifying fruits as they are moving on a processing line. The main objective was the development and testing of a dual task trackingclassifying algorithm that combines low computational burden with acceptable accuracy to be implemented in commercial fruit processing facilities. The new feature of the methodology is that it employs a single camera, dual-task algorithm suitable for real time applications introducing a new concept in RGB space called a main components matrix (MCM).

\section{MATERIALS AND METHODS}

\section{Camera calibration}

The images were captured using a charge coupled device (CCD) color webcam pixel view $\mathrm{XC} 75 \mathrm{~B} / 465$, (Philips, Lisboa, Portugal), with capture card and output image size of $640 \times 480$ pixels using the standard National Television System Committee (NTSC). The webcam was equipped with a $3.8 \mathrm{~mm}$ F 2.0 lens and a viewing angle of $39^{\circ}$. Images were processed with a personal computer (PC) Pentium-S/166 MHz and $64 \mathrm{MB}$ in random access memory (RAM). A geometrical camera calibration procedure was applied to estimate a set of camera intrinsic and extrinsic parameters for mapping between three-dimensional (3D) space and two-dimensional (2-D) image coordinates (Bouget, 1999). In order to carry out the calibration of the camera, the analytical approach described by Samtaney (1999) was selected as appropriate for the architecture of our simulated system. The procedure employs a minimum of three check board images, $640 \times 480$ pixels in size, taken at different orientations that are then processed with Matlab software (Bouget, 2001), to obtain intrinsic and extrinsic calibration parameters. In the present case, 12 calibration images of a check board with $15 \times 15,30 \mathrm{~mm}$ squares were used. An additional image calibration for the check board resting on the working plane was added in order to obtain the extrinsic parameters of the task surface, which it is necessary to determine the distance from the camera frame to any point on the working surface.

\section{Object recognition and position estimation}

A method for color feature extraction is proposed in order to recognize the class or type of object and determine its position in the image. The method involves two steps. In the first step, the goal is to locate any point belonging to the object. To do this, a matrix $F(M \times N)$ of the same size of the image with zero valued elements is created. Once the image is acquired, color components $(r, g)$ of each pixel are computed and compared against the first, or the first and the second columns of matrix MCM. When equality is found, $F$ is set to one at the corresponding pixel position. The operation can be expressed as follows:

$$
F(i, j)=\left\{\begin{array}{l}
1 \text { if }\left\{\begin{array}{l}
f_{r}(i, j)=H_{M}(2,1) \cap f_{g}(i, j)=H_{M}(3,1) \\
U \\
f_{r}(i, j)=H_{M}(2,2) \cap f_{g}(i, j)=H_{M}(3,2)
\end{array}\right. \\
0 \text { if }\left\{\begin{array}{l}
f_{r}(i, j) \neq H_{M}(2,1) \cap f_{g}(i, j) \neq H_{M}(3,1) \\
\cup \\
f_{r}(i, j) \neq H_{M}(2,2) \cap
\end{array}\right.
\end{array}\right.
$$

The two highest frequencies of MCM used to recognize the object have to be determined as ( $\mathrm{r}, \mathrm{g})$ averages of a sample of a group or universe of objects of a certain class in order to have a high probability of finding a pixel of the object image containing any of these two high frequency colors.

Once the entire image is processed with the logical operation of Equation [7], matrix $F$ is searched for the column with maximum non-zero elements (ones) to locate the horizontal position of a pixel inside the object. The sum $S j$ of all row values for each column of $F$ can be written as:

$$
S_{j}=\sum_{i=1}^{M-1} F(i, j)
$$

therefore the horizontal position $n_{\mathrm{x}}$ of the pixel pertaining to the object is equal to the $j$ value such that $S_{\mathrm{j}}$ is maximum in Equation [8]:

$$
n_{x}=j \mid \text { so that } S_{j} \text { is maximum }
$$

For the vertical positioning in the image, a search along the column $n_{x}$ is made until the first non-zero value (one) is found. The expression for the $n_{y}$ position of the point belonging to the object, is then: 


$$
n_{y}=i \mid \text { for first value of } F\left(i, n_{x}\right) \neq 0
$$

the second step involves a refinement of the first process, in order to locate the approximate center of area of the image projection of the object. Here more columns of $\mathrm{MCM}$ are considered to include the maximum number of chromatic components of the object and therefore the maximum number of image points pertaining to the object. The acceptable number of columns or selective color components from matrix MCM to be used in the recognition process will depend on the degree of accuracy desired with respect to the best estimation feasible. Experimentally it has been shown that at least five columns of MCM are required to obtain a good approximation of the center of area (Reyes, 2002), which means an error of about $2 \%$. The final step employs the pixel position $\left(n_{x}, n_{y}\right)$ inside the object image, located previously, as the center pixel of a processing window around the object. The window is selected as a $2 d \times 2 d$ square centered at $\left(n_{x}, n_{y}\right)$ (Figure 2). To estimate $d$ in pixels, the previous image sampling of the largest size $N_{T}$ (in pixels) of a certain object class or type, was considered. Estimation of $d$ can then be made as:

$$
d=1.2 \sqrt{\frac{4 N_{T}}{}}
$$

Equation [11] assumes a circular projected object shape, but shape deviation is allowed by increasing the searching region by $20 \%$. The origin of the window positioning $\left(n_{x o}, n_{y o}\right)$ is then:

$$
\begin{aligned}
& n_{x o}=n_{x}-d \\
& n_{y 0}=n_{y}-d
\end{aligned}
$$

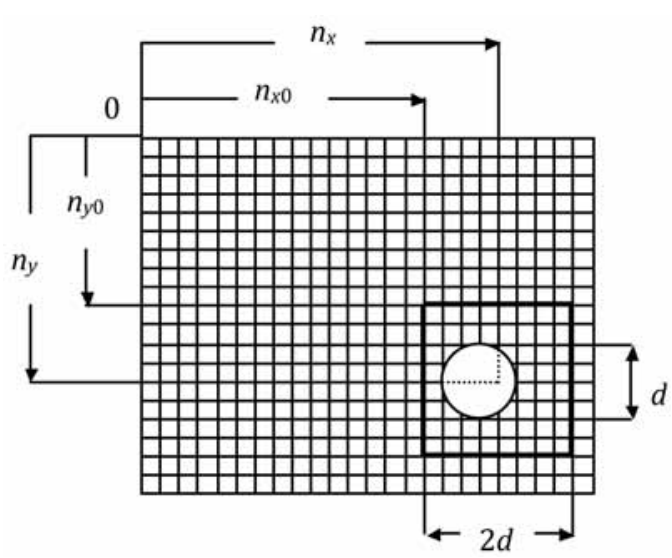

Figure 2. Window for evaluating center of area, d: average diameter of the object; $\mathbf{n}_{\mathrm{x} 0}, \mathbf{n}_{\mathrm{y} 0}$ : coordinates of origin of image window; $\mathbf{n}_{x}, \mathbf{n}_{\mathbf{y}}$ : coordinates of center of area of the object in on the image window.
The chromaticity $(r, g)$ of each pixel in the window is compared to the first five columns of the MCM. The respective coordinates $\left(n_{j}, n_{i}\right)$ of each pixel, with respect to the origin of the window position (upper left corner) are evaluated through the following numerical operation:

$$
h_{j,} n_{i}=\left\{\begin{array}{l}
j, i\left\{\begin{array}{c}
\text { if } f_{r}(i, j)=H_{M}(2, h) \cap f_{g}(i, j)=H_{M}(3, h) \\
\text { for } h=1,2, \ldots . .5
\end{array}\right. \\
0,0\left\{\begin{array}{c}
\text { if } f_{r}(i, j) \neq H_{M}(2, h) \cup f_{g}(i, j) \neq H_{M}(3, h) \\
\text { for } h=1,2, \ldots . .5
\end{array}\right.
\end{array}\right.
$$

where: $i, j=1,2,3 \ldots \ldots . .2 d$. If $K$ is the number of pixels where the pair $\left(n_{j}, n_{i}\right)$ in Equation [13] is non-zero; and $n_{j k}$ ,$n_{i k}(k=1,2,3 \ldots . . K)$ are the corresponding coordinates, the approximate position of the center of area of the object projection is calculated as follows:

$$
\begin{aligned}
& \bar{n}_{x}=n_{x 0}+\frac{\sum_{k=1}^{K} n_{j k}}{K} \\
& \bar{n}_{y}=n_{x 0}+\frac{\sum_{k=1}^{K} n_{i k}}{K}
\end{aligned}
$$

the coordinates obtained in Equation [14] corresponds to the components of the vector $\boldsymbol{X}_{p}=\left\lfloor x_{p}, y_{p}\right\rfloor=\left\lfloor\bar{n}_{x}, \bar{n}_{y}\right\rfloor$, which represents the distorted projection of the point on the image plane.

\section{Classification of fruits}

This methodology allows discrimination between objects from the same generic class, for example any fruit at some specific state of ripening. In order to implement an algorithm for the identification of objects by color features, a procedure is explored based on the chromatic data contents in the differential histogram defined in Equations [4] and [5]. The differential histogram targets the segmentation of the object from the background (separation of the object and background pixels) hereby referred to as the Background Object Segmentation (BOS). First, we group objects according to chromatic similarity (degree of ripening in the case of fruits), by calculating the average $(\bar{r}, \bar{g})$ of the normalized chromaticity components $r$ and $g$ of each object in a group (fruits with the same degree of ripeness), by means of the expressions:

$$
\bar{r}=\frac{\sum_{i=0}^{255} \sum_{j=0}^{255} r(i, j)}{\mathrm{N}_{\mathrm{s}}}\left[\operatorname{sing}\left(H_{\mathrm{OB}}(i, j)\right)\right]
$$




$$
\bar{g}=\frac{\sum_{i=0}^{255} \sum_{j=0}^{255} r(i, j)}{\mathrm{N}_{\mathrm{s}}}\left[\operatorname{sing}\left(H_{O B}(i, j)\right)\right]
$$

where $N_{S}$ is the number of pixels obtained from object segmentation. To estimate the average color representative of a given group (similar degree of ripening), the average of averages $(\overline{\bar{r}}, \overline{\bar{g}})$ within the group of $n$ objects is evaluated:

$$
\begin{aligned}
& \overline{\bar{r}}=\frac{\sum_{k=1}^{n} \bar{r}_{k}}{n} \\
& \overline{\bar{g}}=\frac{\sum_{k=1}^{n} \bar{g}_{k}}{n}
\end{aligned}
$$

The next step is to evaluate the longest Euclidean distance $D_{M}$ on the $r g$ plane, between each of the $n$ points $(\bar{r}, \bar{g})$, corresponding to an object of the group and the point $(\overline{\bar{r}}$, $\overline{\bar{g}}$ ), which characterize the group:

$$
\left(D_{M}\right)_{i}=\operatorname{maximum}\left[\sqrt{\left(\overline{\bar{r}}_{i}-\bar{r}_{j}\right)^{2}+\left(\overline{\bar{g}}_{i}-\bar{g}_{j}\right)^{2}}\right]
$$

where $i=1,2, \ldots \ldots . . m$ and $j=1,2, \ldots \ldots \ldots . .$.

The critical distances $\left(D_{M}\right)_{i}$ for each group can be employed as a parameter for the classification of any object in one of the $m$ possible groups. To select objects belonging to any of the $m$ groups, we have $m$ components $(\overline{\bar{r}}, \overline{\bar{g}})$ that can be utilized to identify the ownership of each object. The proposed selection criterion involves evaluating the Euclidian distance $\left(d_{o}\right)_{i}$ in the $r g$ plane from the point $\left(\bar{r}_{o}-\bar{g}_{o}\right)$ for each object to the reference point $\left(\overline{\bar{r}}_{i} \quad \overline{\bar{g}}_{i}\right.$ ) of each one of the $m$ groups:

$$
\left(d_{o}\right)_{i}=\sqrt{\left(\overline{\bar{r}}_{i}-\bar{r}_{o}\right)^{2}+\left(\overline{\bar{g}}_{i}-\bar{g}_{o}\right)^{2}}
$$

where $i=1,2, \ldots \ldots . . . m$.

To classify any object, the system has to determine which group $i$ satisfies the following relationship:

$$
\left(d_{o}\right)_{i} \leq\left(D_{M}\right)_{i}
$$

On the other hand, to locate and track the object, it is also possible the estimation of the position of its center of area by processing the pixels obtained by means of the Equations [4] and [14].

\section{Fruit recognition}

Testing of the procedure was performed using four types of fruits: nectarine, orange, apple and kiwi. The background of the working surface was painted opaque black in order to enhance the discrimination of color features between the environment and fruits. Indirect natural daylight was used from a distant window and filtered by an existing shadowing curtain to avoid reflections caused by direct incident rays. Images of a group of 20 fruits of each type were taken along with an image of the plain background. From each fruit an image window was processed by removing the background pixels and replacing them with pixels of a black color, $(R, G, B)=(0,0,0)$. Files of the modified windows were processed to get average normalized $(r, g)$ histogram defined in Equation [3]. At the same time, a normalized histogram of the background image was also quantified. The differential histogram of each fruit with respect to the background was evaluated by means of Equation [4], followed by the MCM matrix defined in Equation [6]. To locate the center of area of the fruit, a two step computer routine was implemented, where the first step included Equations [7] to [10] and the second, Equations [11] to [14]. These equations yield the two first columns of MCM matrix and the five first columns of MCM respectively.

\section{Experimental classification tests}

In order to test the procedure for fruit classification, oranges and apples with distinct color appearance were used. For each type of fruit, 50 fruits with acceptable commercial color were selected and isolated from other group of 50 fruits with deficient color appearance. This procedure was accomplished by using human vision, as is normally done in some manual classification operations. From each of these groups, 11 fruits were randomly grouped to extract color indexes. First the histogram of an image of the isolated background was evaluated, and then the histogram of a window around each fruit. The segmentation of each fruit was finally done by subtracting the average background histogram from the histogram pertaining to each fruit using Equation [4]. For each of the oranges tested, the average of the normalized components $(\bar{r}, \bar{g})$ was evaluated according to Equation [5]. The following step involved the estimation of the average of averages $(\overline{\bar{r}}, \overline{\bar{g}})$ for each group of similar ripening level, with Equation [16]. Then the maximum permissible distance to this point for each group was determined, by means of the Equation [17]. The averages $(\overline{\bar{r}}, \overline{\bar{g}})$ calculated for oranges and apples, along with the maximum permissible Euclidian distance $D_{M}$ of Equation [17], were inserted into the algorithm used to test the methodology. 


\section{Classification and tracking in real time}

Simulated and real tests were performed by means of a multi-thread computer code written in API Windows/ $\mathrm{C}++$ that incorporates the analytic formulation of the method described previously. An initial scanning window of $50 \times 50$ pixels was used along with the dual step MCM algorithm in order to first locate one pixel that belongs to the mobile fruit, and then to estimate its approximate center of area on the image plane. Once position on the image plane is evaluated, the BOS methodology to segment and classify fruit was applied. After object classification was accomplished, the instantaneous center of area was then employed as reference to position and translate a small tracking window of $30 \times 30$ pixels.

The continuous evaluation of the center of area of a fruit inside the tracking window, along with the image to space transformation, was used to simulate the positioning of a virtual Selective Compliant Assembly Robot Arm (SCARA) manipulator in real time.

\section{RESULTS AND DISCUSSION}

\section{Fruit recognition}

The averages of five main color components of each type of fruit are shown in Figure 3. Output images in Figure 4 depict the center of area of four fruits (one at a time). In the left image, white crosses indicate the first pixel detected within a fruit. It is important to point out that when there were more than one occurrence (i.e., more than one unit of a type of fruit); the algorithm picked up the object located on the column where more pixels of highest color frequency were found (Equations [7] to [10]). The right frame of Figure 4 illustrates the final output of the method, with white crosses indicating the estimated position of the center of area of every kind of fruit.

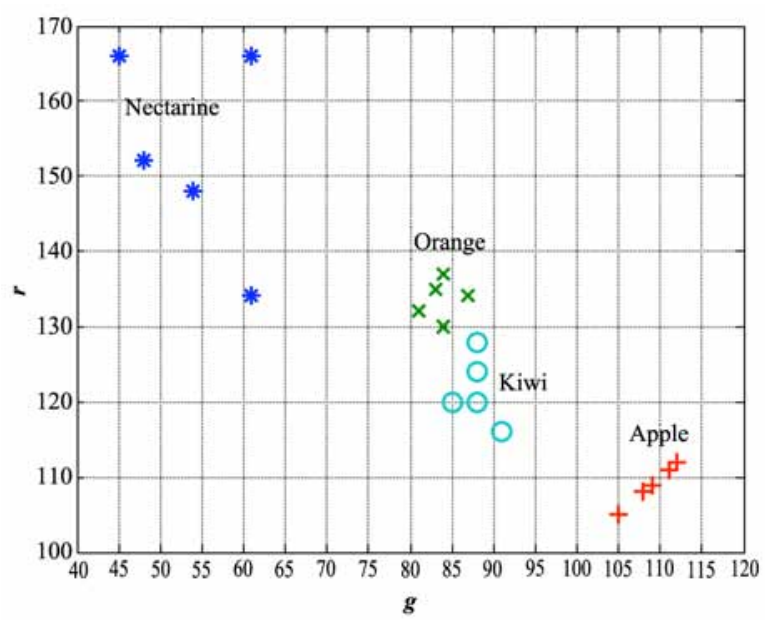

Figure 3. Main color components of fruits, g: green normalized component; r, red: normalized component.

\section{Classification of fruits}

In Figure 5 an example of background-object segmentation (BOS) for an orange is illustrated, after applying Equation [4]. The pixels painted in black are those identified as belonging to the object. The observed discontinuities are due to noise and color coincidences among the background and the object.

For the purpose of the present analysis, only two regions were identified (Figure 6). The first corresponds to the fruits whose level of ripening is adequate to be accepted (good degree of ripening), while the second region includes those fruits that do not fit the color ripening condition and should be rejected. In this case the objective was testing the method and therefore only two regions were utilized. More generally, it is possible to establish a greater number of regions representing intermediate levels of ripening. The values $(\overline{\bar{r}}, \overline{\bar{g}})$ for both groups are shown as the center of circles forming each region (Figure 6). The radius of the circle indicates the maximum distance allowed for an object with components $(\bar{r}, \bar{g})$ to be considered as belonging to the group. Based on this analysis, many groups of fruits can be allocated or classified.

\section{Classification and tracking in real time}

A simulated sequence of the method while locating and classifying oranges is shown in Figure 7. Note that the simulated position of the manipulator in the image plane is reproduced virtually using a look-and-move procedure to position the end effector. In the first frame, the border of the initial scanning window is depicted. The second frame shows a random instant captured, while in the third frame the scanning window is still working. In the fourth frame an orange has been classified and tracked with the smaller window.

Numerical results of experimental tests carried out with the method are presented in Table 1. Apples and oranges were visually classified and separated into ripened and unripened. In both cases 50 unripened fruits mixed with 50 ripened fruits were tested using two values of the classification parameter $D_{M}$ of Equations [17] and [19] previously evaluated using each fruit group. Three repetitions of the test were performed with the same sample. The first value of $D_{M}$ for each type of fruit (Table 1 ) is the value given by Equation [17] and the second incorporates a $20 \%$ increase in $D_{M}$ in order to try to improve performance. Outcomes indicated an error fluctuating between $2.0 \%$ and $4.6 \%$ depending on the value of $D_{M}$, and demonstrated that it is possible to get a proper adjustment of the value of $D_{M}$ for optimum response.

Even thought it is possible to adjust the size of the tracking window; the velocity of the center of this window is determined by the sampling rate of the camera. For the 

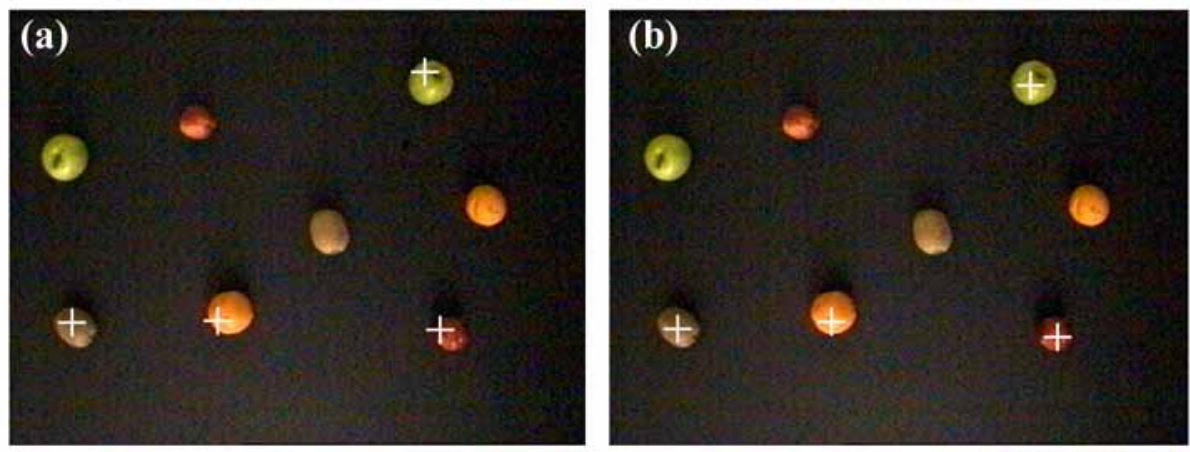

Figure 4. Estimation of center of area for a set of fruits. (a) Determination of a pixel pertaining to the fruit; (b) Determination of the center of area of the fruit.

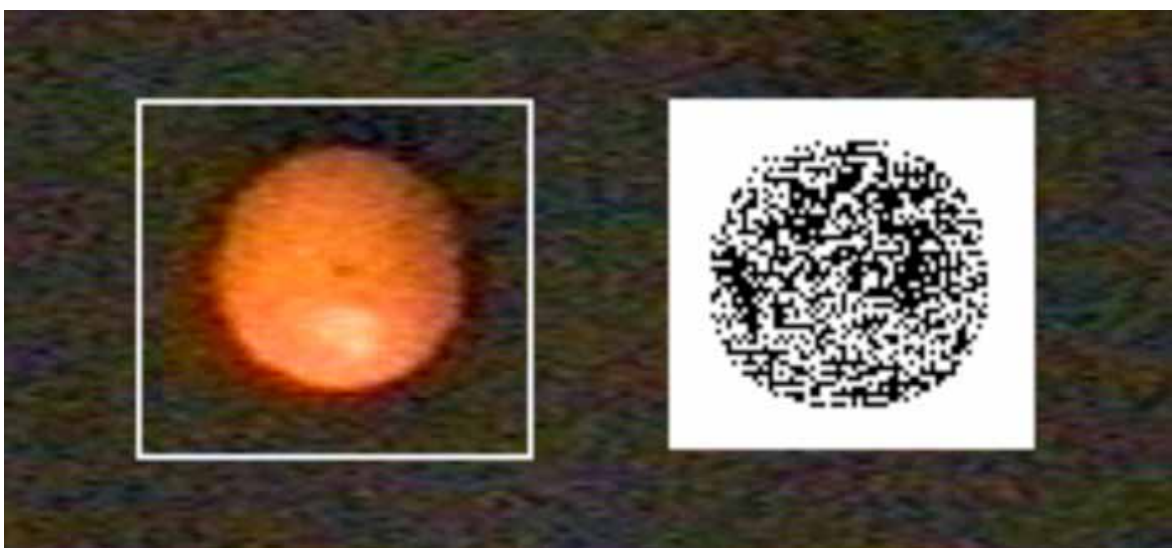

Figure 5. Segmentation of an orange.

trials carried out in this research, typical processing times of each image frame were around 50 to $60 \mathrm{~ms}$, which is less than the speed permitted by the capture rate of our equipment at $66 \mathrm{~ms}$ per frame corresponding to 15 images per second. For a square window of 30 pixels, the tracking

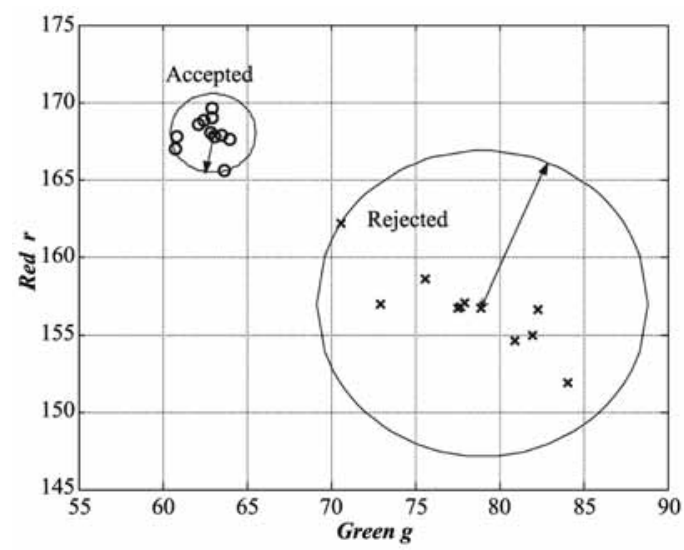

Figure 6. Classification of oranges into groups, g: green normalized component; r: red normalized component. Small circle represents rejected fruits. Large circle represents accepted fruits. operation can be done at a maximum speed of about 450 pixels $\mathrm{s}^{-1}$. This speed corresponds in spatial coordinates to a translation velocity of about $0.5 \mathrm{~m} \mathrm{~s}^{-1}$, a magnitude that is consistent with the speed of conveying systems used in commercial classification lines for vegetables and fruits.

\section{CONCLUSIONS}

The methodology presented here uses a single color camera as the sensing device, along with an image to space tracking and classification procedure for fruits. The algorithm proved to be an efficient alternative in classifying and tracking mobile fruits using color feature extraction. The control architecture of a manipulator using the algorithm is beyond the scope of this research, therefore the tracking method was tested assuming a constant moving speed of the fruits. Additional work has to be done in order to evaluate in detail the dynamic behavior of a manipulator employing the methodology developed. Since the proposed methodology was tested under natural lighting conditions, uniform structured lighting may be necessary in order to check operating accuracy of the system. Even though an acceptable 

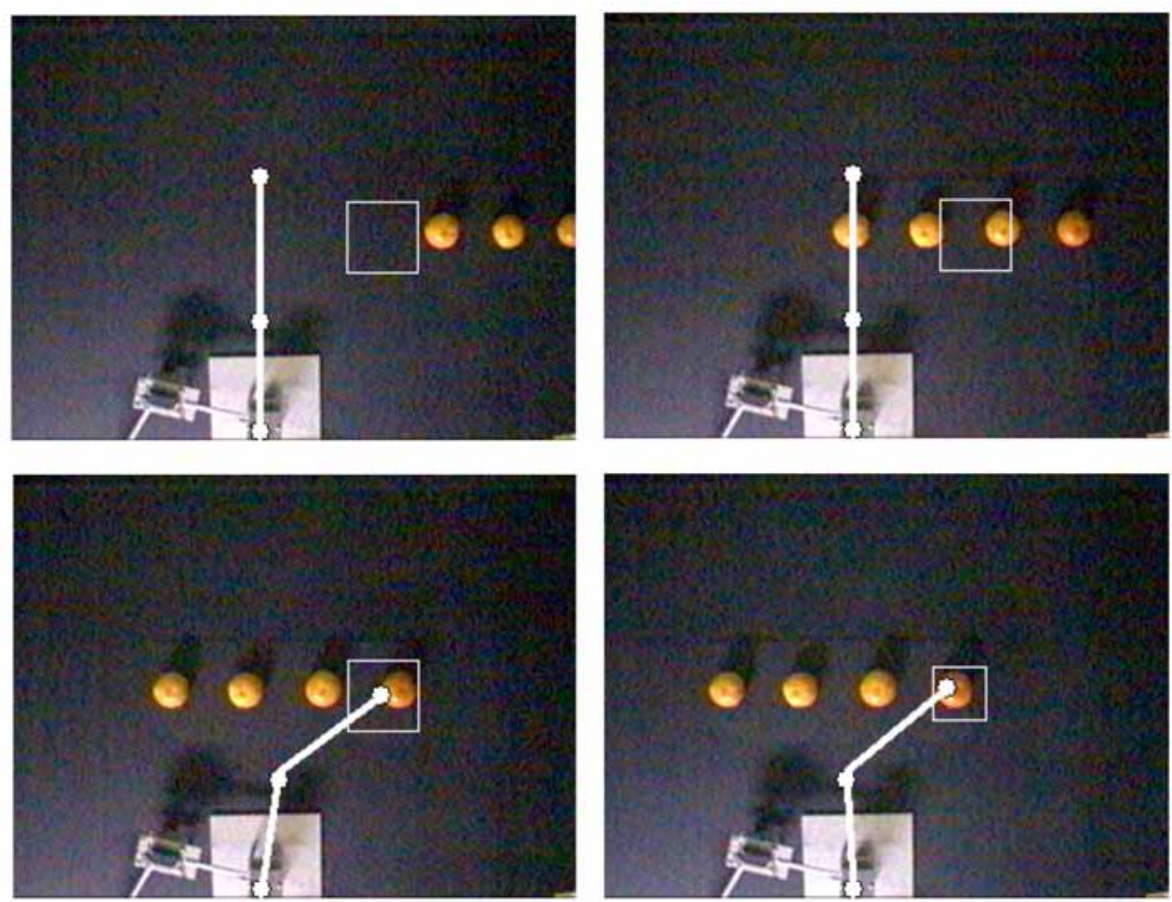

Figure 7. Sequential frames of the simulated methodology captured from the computer screen.

classification error was observed, considerable improvement of the proposed method may be achieved using artificial lighting. In summary, the significant and interesting aspect of this study comprise the deployment of conventional microcomputers and color cameras in devising new automated image-based methodologies to achieve the same objectives as more complex automated architectures.

\section{ACKNOWLEDGEMENTS}

The authors are grateful to the Comisión Nacional de Ciencia y Tecnología (CONICYT), and all the people of the Departamento de Mecánica e Ingeniería Metalúrgica of Escuela de Ingeniería, Pontificia Universidad Católica de Chile, for their help to the research that supported this publication. Special thanks to Doctor Shahriar
Negahdaripour for his excellent suggestions about the presentation of this document.

\section{RESUMEN}

Localización y clasificación de frutas móviles en tiempo real con una cámara individual a color. El control de calidad en frutas y hortalizas para satisfacer mercados cada vez más exigentes, requiere la implementación de sistemas automáticos servo visuales en operaciones de procesamiento de frutas para responder a estos desafíos de mercado. En este trabajo se desarrolló y evaluó un nuevo método para identificar y clasificar frutas en movimiento mediante el procesamiento en tiempo real de imágenes en color capturadas por una cámara individual estática. Se combinaron dos algoritmos para clasificar y rastrear frutas

Table 1. Experimental results for fruit classification tests.

\begin{tabular}{lccccc}
\hline Fruit type & $\begin{array}{c}\text { Number of } \\
\text { tested fruits }\end{array}$ & $\begin{array}{c}\text { Euclidian } \\
\text { distance }\left(\mathbf{D}_{\mathbf{M}}\right)\end{array}$ & $\begin{array}{c}\text { Number of } \\
\text { rejected fruits }\end{array}$ & $\begin{array}{c}\text { Number of } \\
\text { failures }\end{array}$ & $\begin{array}{c}\text { Error } \\
\text { \% }\end{array}$ \\
\hline Apples & 50 & 2.0 & 47.7 & 2.3 & 4.6 \\
& 50 & 2.4 & 48.3 & 1.7 & 3.4 \\
\hline Oranges & 50 & 1.5 & 48.7 & 1.3 & 2.6 \\
& 50 & 1.8 & 49.0 & 1.0 & 2.0 \\
\hline
\end{tabular}

$\mathrm{D}_{\mathrm{M}}$, maximum value of the Euclidian distance for a group on the color plane. 
en movimiento en el plano de imagen utilizando aspectos representativos de color. El método permite clasificar las frutas en base a segmentación de color y estimar su posición en el plano de imagen, lo cual proporciona un algoritmo confiable para ser implementado en un brazo robótico de manipulación de frutas. Para evaluar la metodología se empleó un sistema experimental simulando una correa transportadora real de movimiento de frutas. La evaluación del sistema indicó que en condiciones de iluminación natural es posible obtener un error mínimo de $2 \%$ en la efectividad de clasificación de frutas, con una calibración apropiada del sistema. El método es de implementación sencilla y aunque los resultados experimentales son promisorios se podría obtener una mayor precisión si se emplea luz estructurada.

Palabras clave: clasificación de frutas, aspectos de color, control servo visual, mirar y mover.

\section{LITERATURE CITED}

Berens, J., G.D. Finlayson, and G. Qiu. 2000. Image indexing using compressed colour histograms. IEEPVis. Image Sign. 147(4):349-355.

Blasco, J., N. Aleixos, and E. Moltó. 2003. Machine vision system for automatic quality grading of fruit. Biosyst. Eng. 85(4):415-423.

Bouget, J.Y. 1999. Visual methods for three-dimensional modeling. Ph.D. thesis. 214 p. California Institute of Technology, Pasadena, California, USA.

Bouget, J.Y. 2001. Camera calibration toolbox for Matlab. California Institute of Technology, Pasadena, California, USA. Available at http://www.vision. caltech.edu/bouguetj/calib_doc/ (Accessed December 2007).

Deng, L., F. Janabi-Sharifi, and W.J. Wilson. 2005. Hybrid motion control and planning strategies for visual servoing. IEEE T. Ind. Electron. 52(4):1024-1040.

Gans, N.R., S.A. Hutchinson, and P.I. Corke. 2003. Performance tests for visual servo control systems, with application to partitioned approaches to visual servo control. Int. J. Robot. Res. 22:955-981.

Gheissari, N., and A. Bab-Hadiashar. 2003. Motion analysis: Model selection and motion segmentation. p. 442. In 12th International Conference on Image Analysis and Processing (ICIAP’03), Mantova, Italy. 17-19 September 2003. Institute of Electronics Engineers (IEEE) Computer Society, Washington D.C., USA.
Horiuchi, T. 2006. Grayscale image segmentation using color space. IEICE T. Inf. Syst. Volume E89-D 3:12311237.

Leemans, V., H. Magein, and M. Destain. 2002. On-line fruit grading according to their external quality using machine vision. Biosyst. Eng. 83(4):397-404.

Penman, D.W. 2001. Determination of stem and calyx location on apples using automatic visual inspection. Comput. Electron. Agr. 33(1):7-18.

Recce, M., A. Plebe, G. Tropiano, and J. Taylor. 1998. Video grading of oranges in real-time. Artif. Intell. Rev. 12(1-3):117-136.

Reyes, J.F. 2002. Clasificación y rastreo de frutas con un manipulador SCARA y una cámara a color. 101 p. Tesis de Doctorado. Pontificia Universidad Católica de Chile, Facultad de Ingeniería, Santiago, Chile.

Reyes, J.F., and L. Chiang 2003. Image-to-space path planning for a SCARA manipulator with single color camera. Robotica 21:245-254.

Samtaney, R. 1999. A method to solve interior and exterior camera calibration parameters for image resection, NAS-99-003. MRJ Technology Solutions, NASA Ames Research Center, Moffett Field, California, USA.

Stavnitzy, J., and D. Capson. 2000. Multiple camera model-based 3-D visual servo. IEEE T. Robot. Autom. 16(6):732-739.

Taylor, G., and L. Kleeman. 2004. Hybrid position-based visual servoing with online calibration for a humanoid robot. p. 686-691. In Proceedings of 2004 IEEE/RSJ International Conference on Intelligent Robots and Systems (IROS), Sendai, Japan. 28 September - 2 October, 2004. Institute of Electrical and Electronic Engineers, (IEEE), Los Alamitos, California, USA.

Vertan, C., and N. Boujemaa. 2000. Spatially constrained color distribution for image indexing. p. 261-265. In International Conference on Color in Graphics and Image Processing (CGIP), Saint-Étienne, France. 1-4 October 2000. Univ. of Saint- Étienne, Saint-Étienne, France.

Xiao, N., and I. Todo. 2001. Stereo vision-based robot servoing control for object grasping. JSME Int. J. Series C 44(1):61-68. 


\title{
EFFECT OF QUANTITY AND DISTRIBUTION OF RAINFALLS ON Hordeum murinum L. GROWTH AND DEVELOPMENT
}

\author{
Myrna Johnston B. ${ }^{*}$, Alfredo Olivares E. ${ }^{1}$, and Carolina Calderón E. ${ }^{1}$
}

\begin{abstract}
The growth and development of Hordeum murinum L. seeds growing with extreme pluviometric regimes in cool greenhouse conditions were evaluated. Seven treatments according to quantity and distribution of real rainfalls of the semiarid zone of the Metropolitan Region, Chile were applied: rainy-late, normal-late, dry-early, rainy-normal, normal-early and dry-late, plus a reference without water stress, at $2 / 3$ field capacity. The experimental design was randomized complete blocks with five replicate pots. Seeds produced in the last year were sown in pots with disinfected soil leaving the more uniform plants after emergence. Evaluations were made of phytomass production, spearing shoots of roots, the quantity of floral stems and seeds, their total weight and the proportion of seed annex structures, and the viability and germination capacity of seeds. The life cycle of dry years was shortest and with the least dry shoot matter production, the rainy-normal and normal-late years had similar dry root matter production, therefore the most important factor was rainfall distribution. All the reproductive growth values were lower than the reference. There was no seed production in both distributions of dry years and in the normal-early. There were only differences in late distributions, there were no differences among treatments in seed quality. Thus, $H$. murinum uses its resources principally for seed production and late distributions determined seed production.
\end{abstract}

Key words: pluviometric regime, reproductive efficiency, naturalized poacea.

\section{INTRODUCTION}

Annual pasture grasses of the Mediterranean climate of the semi-arid zone of Chile represent the main source of forage for cattle production in areas subjected to water deficits. The magnitude, floral diversity and persistence of the species that make up these ecosystems, as well as the richness of the seed bank in the soil, depend in large measure on the environmental conditions of the location. The phenology and productivity of the species present are regulated by diverse factors, among them are notably the availability of water, which determines the beginning of the life cycle, and temperature, which affects the growth velocity and development of each species. The combination of scarce water resources and high temperatures determines the end of the cycle of annual winter species whose seeds germinate and develop in spring (Castellaro and Squella, 2006). The reproductive stage that precedes the end of the cycle is

${ }^{1}$ Universidad de Chile, Facultad de Ciencias Agronómicas, Casilla 1004, Santiago, Chile.

*Corresponding author (mjohnsto@uchile.cl).

Received: 22 January 2008.

Accepted: 01 August 2008. vital in the persistence of terophytes, determining the quantity and quality of seeds that are produced (Johnston et al., 2005).

It has been demonstrated that the production and quality of seeds in Bromus berteroanus Colla (Olivares et al., 2006) and Erodium moschatum (L) L'Her. (Olivares et al., 2004) are strongly determined by precipitation during the reproductive period, given that this determines water availability during the fruiting period. Dry matter (DM) production in this species also depends on the distribution of precipitation and consequently could indirectly affect reproductive parameters through the number of flower stems induced and the provision of carbohydrates assimilated by these (Johnston et al., 2003).

Pluviometric regimes in Mediterranean zones are characterized by high variability in rainfall in both distribution and total levels, because of which native or naturalized species must modify their growth and development, changing, for example, the duration of the periods from emergence to establishment, or the growth rate (Olivares et al., 1998). Acuña (1978) in a pioneering work, simulated pluviometric regimes in situ and determined that DM production of annual pasture in a Mediterranean climate increases in those years with 
normal total precipitation, or rainy years, and can also increase or decrease according to the type of distribution of rainfall over the year.

Some seeds of annual species in semi-arid zones only germinate if the level of rainfall is sufficient for the plants to complete this stage and exceed $96 \mathrm{~h}$ of hydration. The subsequent growth of these plants will depend on the timing and level of rainfall and the soil water potential (Jara et al., 2006; Castellano and Squella, 2006). Germination and emergence respond to precipitation levels close to or higher than $20 \mathrm{~mm}$ in a single rainfall or accumulated in two weeks (Johnston et al., 1998). Rainfall levels in Chile of around $10 \mathrm{~mm}$ can be effective for naturalized plants with superficial roots; similar rainfall values were found by Volis (2007) to initiate germination found in Hordeum spontaneum Koch. and Avena sterilis L. in Israel. On the other hand, higher precipitation levels than these are important for deep-rooting native Chilean species (Gutiérrez, 1993).

As well, it has been established that seed weight is important, in that a greater initial quantity of nutrients generates seedlings of greater vigor, thus assuring a better establishment of the plant and allowing for higher production of seeds (Lorenzetti, 1993). It has been observed that seed weight in ryegrass (Lolium perenne L.) is highly variable, depending on climatic conditions under which the seeds develop. As well, climate influences the weight of ovums until anthesis, the moment at which the partition of assimilates is determined (Warringa et al., 1998).

In relation to the availability of water, Kokubun et al. (2001) determined that soya plants submitted to water stress produce a lower number of seeds owing to a reduction in photosynthesis; if the deficit occurs during flowering, there is a lower number of assimilates that go to floral structures and consequently there is a smaller number of floral abortions due to damage to the pistils or stamens.

In a study on the effects of pluviometric regimes on the behavior of $B$. berteroanus Colla, one of the most abundant species and of greater forage potential in annual pastures in semi-arid Mediterranean climates, the premise was tested that seed growth and production improved in years with a late distribution of rainfall, whether rainy or normal, and with the dry-early years (Johnston et al., 2005). It can be considered that not only is the quantity of available water important, but also rainfall distribution. Thus, even though there may be less available water in the environment, if this condition is accompanied by other favorable conditions (light and temperature) growth is favored.

Hordeum murinum, one of the most common species in semi-arid Mediterranean ecosystems, shows a high rate of initial growth, has better adaptive advantages in the context of moderate water deficit and rapidly reaches a seedling size that competes more effectively with the majority of terophytes of the semi-arid Mediterranean range (Olivares et al., 1997).

In accordance with this information, the hypothesis is proposed that the quantity and distribution of precipitation not only influences the growth and development of $H$. murinum, but also has direct effects on the quantity and quality of seeds produced.

Consequently, the general objective of this work was to study the vegetative and reproductive growth of Hordeum murinum subjected to different simulated pluviometric regimes in cool greenhouse conditions and determine the production and quality of the seeds of these plants.

\section{MATERIALS AND METHODS}

Thirty-five (35) black polyethylene pots were kept under cool greenhouse conditions (without heating), with average temperatures between $15^{\circ}$ and $26^{\circ}$ and mean relative humidity between $73 \%$ and $64 \%$. The pots were $50 \mathrm{~cm}$ deep and with a diameter of $13 \mathrm{~cm}$, with $90 \%$ of soil previously treated with bromomethane to activate existing seeds and subsequently sieved at $5 \mathrm{~mm}$, plus $10 \%$ of poliestirene spheres of the same diameter. Ten seeds of Hordeum murinum (synonymous with Critesion murinum (A. Löve) were planted in each pot. The seeds had been collected at the Agricultural Experimental Station of the

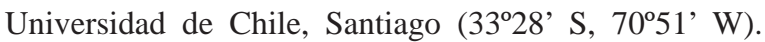
The largest seeds filled with grain were selected, using the most uniform. Seeding was carried out in March in soil with a humidity of $22 \%$ dry base weight prior to the beginning of the rains in all of the treatments. Once the simulated rainfalls that corresponded to each treatment began, the number of seedlings per pot was reduced to the five most vigorous.

Given that $H$. murinum and $B$. berteroanus coexist in the natural pasture of the semi-arid Mediterranean climate, the pluviometric regimes were used that had presented positive $(+)$ or negative effects (-) in the production of B. berteroanus (Olivares et al., 2006). The amount and timing of the application of precipitation in each treatment were made in accordance to the selected year (Figure 1); the first effective rainfall was considered as the beginning of the period and the following applications were made according to the calendar of real precipitation for the selected year (Gutiérrez, 2003). As well, a reference treatment without water restriction was maintained at $2 / 3$ of field capacity, adding water in quantities determined by the difference in the weight of the pots in relation to the initial content that was equivalent to $50 \mathrm{~mm}$ of rain. The soil water content was calibrated on the basis of the data 
obtained by Olivares et al. (2004) for the same type of soil, from the Cuesta Barriga series (Typic Haploxerolls), with which the soil weight was determined at field capacity (100\% of available water). Rainfalls were applied according to the calendar of each year selected using a serum dispenser that simulates drip irrigation, allowing that the corresponding quantity of water was applied over $24 \mathrm{~h}$.

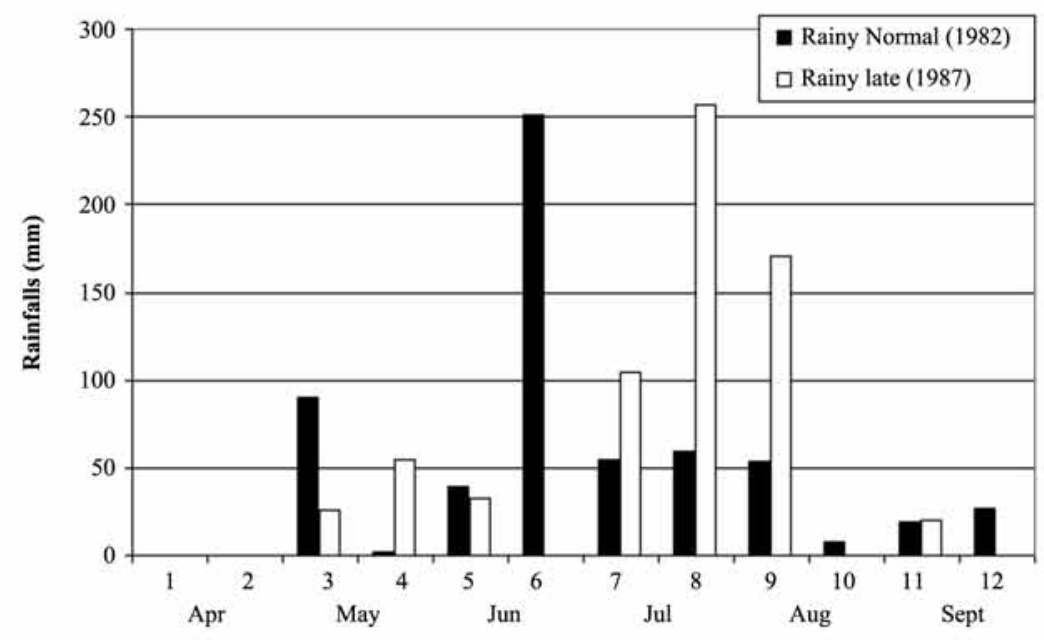

Period (fifteens)

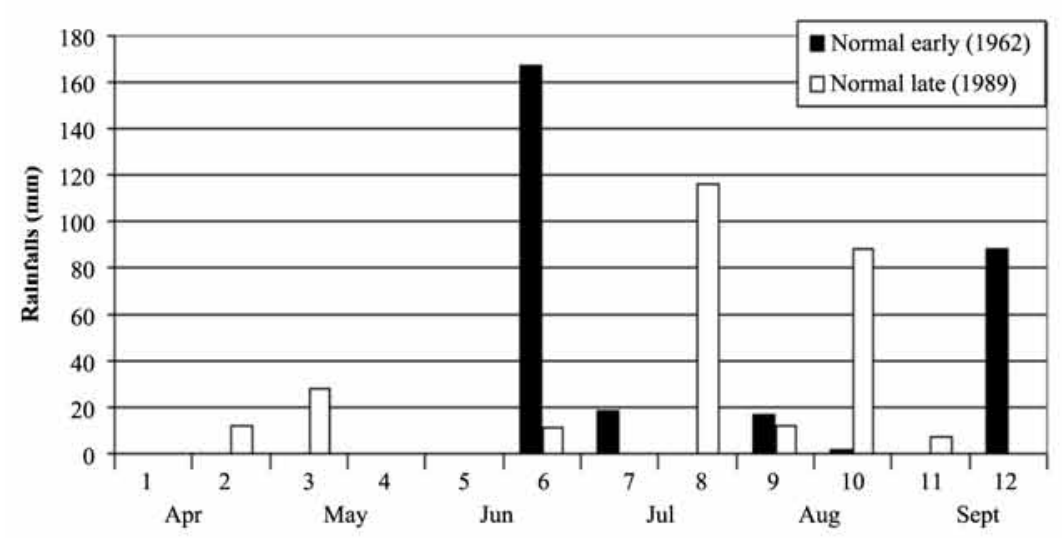

Period (fifteens)

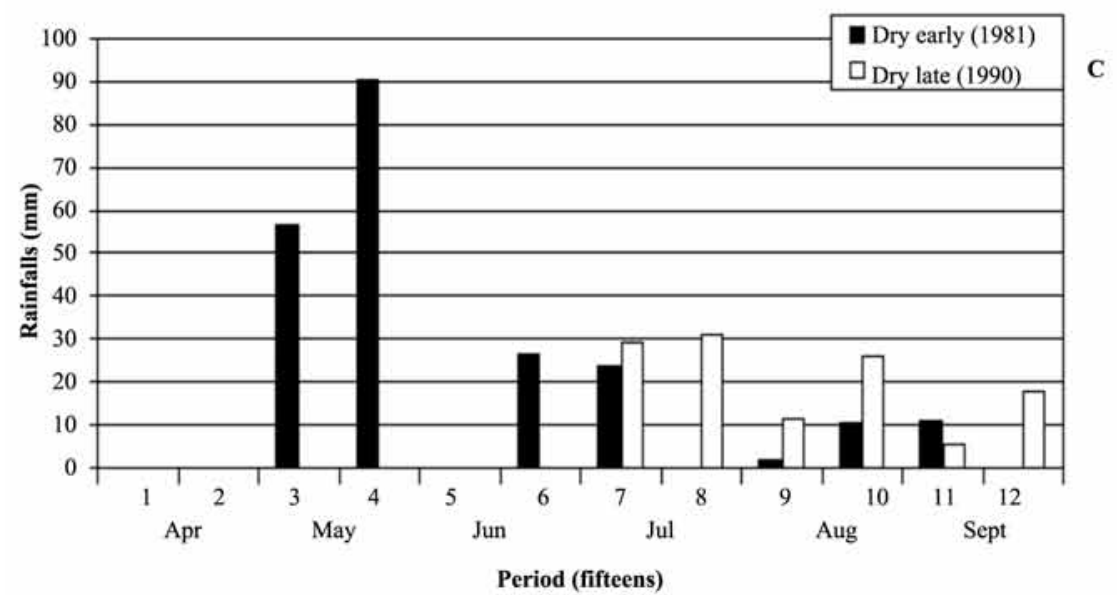

Figure 1. Rainfall distribution (mean of $\mathbf{1 5}$ days) of different selected pluviometric regimes: A) rainy years, B) normal years, C) dry years. 
The treatments used were: Ll-n, rainy year with normal distribution (-) with a total of $628.0 \mathrm{~mm}$ (year 1982); Ll-ta, rainy year with late distribution $(+)$ with a total of $670.6 \mathrm{~mm}$ (year 1987); N-Te, normal year with early distribution (-) with a total of $257.5 \mathrm{~mm}$ (year 1962); $\mathrm{N}$-ta normal year normal with late distribution $(+)$ with a total of $281.4 \mathrm{~mm}$ (year 1989); S-te, dry year with early distribution (+) with a total of $225.2 \mathrm{~mm}$ (year 1981); S-ta, dry year with late distribution (-)with a total of $157.1 \mathrm{~mm}$ (year 1990); and the reference without water restriction (control).

\section{Aerial and root phytomass production}

This was assessed through the determination of phytomass produced in shoots and roots at the end of the annual cycle and was expressed as the average g DM per pot. To obtain the roots, all the soil from each pot was placed in a mesh that was submerged in water for $24 \mathrm{~h}$. The roots were then separated with a fine rain of water over a screen. The material collected was dried in a forced air oven at $70^{\circ} \mathrm{C}$ for $48 \mathrm{~h}$ and was finally weighed to obtain the DM of each part. With these values the root/shoot ratio was calculated.

\section{Production of reproductive phytomass}

Reproductive phytomass was evaluated at the end of the cycle by counting the number of floral stems once the seeds matured; the quantity of seeds at the harvest date (mature ear) and the total weight of seeds per plant. Seed quality was evaluated by the proportion of palea, lemma and arista (annexes) of seeds per plant and per fruit; by the fullness of seeds by separating well-developed seeds with abundant reserves (full) from those that were not developed (empty); by the weight of 100 seeds as an estimation of size; by viability and germinative capacity. For the latter, germinative tests were conducted with 25 seeds on filter paper and water in a Petri capsule, with eight repetitions per treatment and following the international guidelines for seed tests (ISTA, 2007). To determine the viability of seeds that did not germinate, the seeds were submerged in a solution at $1 \%$ of chloride de 2,3,5-triphenyl-tetrazolium for $24 \mathrm{~h}$ at $25{ }^{\circ} \mathrm{C}$ in darkness, measuring reddening in accordance with the ISTA (2007).

The reproductive index (RI) was calculated for each treatment, which is the ratio between the total weight of disseminules and vegetative phytomass per plant, and the reproductive efficiency index (REI), which is the ratio between the number of disseminules per plant and its phytomass weight (Aronson et al., 1993).

\section{Phenology}

The development of the plants was observed and records were made of the main phenological states: emergence, foliation, tillering, elongation of the stem (a sign of floral induction), flowering, formation and maturing of fruit and senescence of the leaves. Each phenophase was registered when it was present in $50 \%$ of the plants in each treatment.

An experimental design with completely random blocks was used, with five replications per treatment. The experimental unit was a pot with five plants. A variance analysis (ANDEVA) was conducted for two ways for each independent variable. When the variation was significant, the means of the treatments were compared using the Newman-Keuls test (Montgomery, 1991). The statistical package Minitab (2000), version 13 was used, with a level of significance of 0.05 .

The analysis of the residuals of the analyzed variable (except percentages) satisfied the suppositions of normality and homogeneity of variances, because of which the usual parametric tests to compare treatments were carried out. In the case of percentages, the data was previously transformed to Bliss degrees.

\section{RESULTS AND DISCUSSION}

The ANDEVA carried out for each variable studied showed in the majority of the cases that there were major differences between the reference treatment without water restrictions and the treatments with different degrees of water deficit (pluviometric regimes), because of which it was decided to conduct a second analysis excluding only the reference in order to compare the behavior of plants subjected to the studied pluviometric regimes.

\section{Production of aerial and root phytomass}

The rainy-late year reached an average value of aerial DM (ADM) per plant (Figure 2) similar to that of the reference treatment (Table 1). The general tendency showed that at lower availability of water the accumulation of ADM decreased; because of which the dry years had the lowest production, followed by the normal-early year. The importance of distribution is notable, given that production in the normal-late year does not differ from that of the rainy-normal year.

The fact that $H$. murinum can express its growth potential in frequent rainy-late year in the dry interior, given production of ADM was similar to the reference treatment without water restriction, suggests that the pluviometric regime could explain in part the success of this species in this type of year. Other poaceae, such as $B$. berteroanus, which co-exists with $H$. murinum in the pasture, does not reach the same growth potential as it reached without water restriction with any of the prototypes of pluviometric regimes detected in the zone (Olivares et al., 2006). 
Table 1. Growth values of Hordeum murinum without water stress (reference treatment).

\begin{tabular}{lr}
\hline Variable & Values \\
\hline Dry aerial material, g plant $^{-1}$ & 2.63 \\
Dry root material, g plant $^{1}$ & 1.35 \\
Root/shoot ratio & 0.51 \\
Quantity of floral stems & 11.20 \\
Total quantity of seeds & 250.70 \\
Fruit weight, mg & 1679.00 \\
Seed weight, mg & 77.00 \\
Quantity of full seeds per plant & 182.20 \\
Quantity of empty seeds per plant & 68.49 \\
Weight of annexes, mg & 914.00 \\
Percentage of germination & 96.00 \\
Percentage of viability & 98.00 \\
Estimated size, mm & 5.59 \\
Reproductive efficiency index (REI) & 0.42 \\
Reproductive index (RI) & 62.98 \\
\hline
\end{tabular}

Lower production in dry years could be because of reduced foliar area when there are conditions of water deficit, owing to the fundamental role of water in cellular expansion (González and Páez, 1995). With normal precipitation, early distribution exercises a negative effect, such that there were no differences in the production of $\mathrm{ADM}$ in comparison to years with low precipitation with any distribution. From this, it can be deduced that late distribution in rainy years is positive and early distribution in normal years is negative, such that distribution can alter the effect expected based on the total quantity of rainfall. The different timing of rainfalls generated by each distribution results in plant growth occurring at different periods, which can imply more or less thermal and light conditions. This can explain the results obtained and also what is often observed in the field (Castellaro and Squella, 2006).

The DM of the roots (RDM) was less sensitive to the quantity and distribution of precipitation given that higher production was obtained only in the rainy-late year, and the rainy-normal year did not present differences with the normal-late year and dry years with any distribution (Figure 2). The quantity of water and the timing of rains also influenced the root growth of this species, such that while there was a similar behavior among most of the years studied, the most favorable was rainy-late, which produced a quantity of DM equivalent to that produced by the reference without water restriction (Table 1). The normal-late year and the rainy-normal showed similar behaviors despite the major differences in the total amount of rainfall.

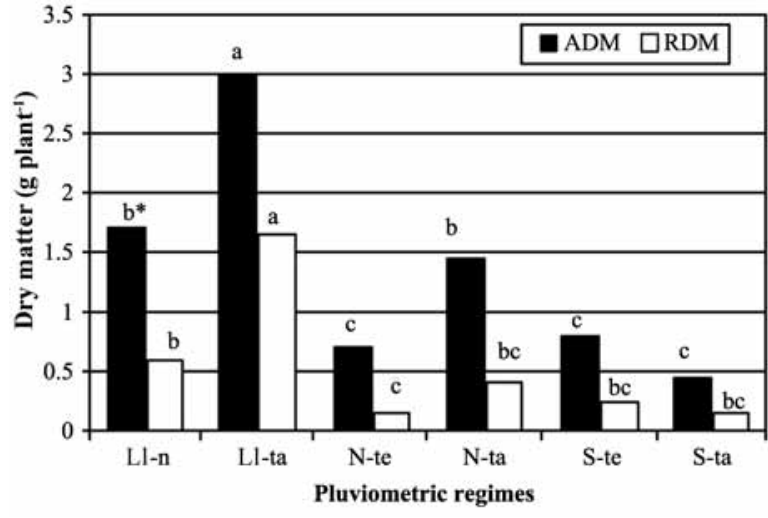

* Different letters over columns of the same color indicate significant differences among treatments $(\mathrm{P} \leq 0.05)$.

Figure 2. Shoot (ADM) and root (RDM) dry matter of Hordeum murinum plants according to rainfall levels and distribution. Ll-n rainy normal, Ll-ta rainy late, $\mathrm{N}$-te normal early, $\mathrm{N}$-ta normal late, S-te dry early, Sta dry late.

Greater root growth in the rainy-late year corroborates the results obtained with Bromus pictus Hook submitted to intense water stress, where the reduction in shoot growth did not significantly alter root growth (Rotundo et al., 2006). Other species also respond to stress by increasing the proportion of assimilates directed to the roots, which allows for diversifying radical growth and thus increase available water for the plant (Huang and Fry, 1998). This explains the similarity of behavior observed in the production of RDM in the different years, with the exception of the rainy-late year. Another work with Festuca arundinacea (Huang and Gao, 2000) showed that a moderate stress reduced the length and production of RDM, increasing on the other hand the development of radical hairs with which a greater provision of water is achieved. In studies on the emergence of species of the annual range in the semi-arid Mediterranean zone, it has been demonstrated that $H$. murinum is the most tolerant to a reduction in soil moisture (Olivares et al., 1997). Thus, the results indicate a greater capacity of $H$. murinum to obtain water, or in effect, less sensitivity to water stress.

On the other hand, the fact that a normal-late year has similar production of DM to that of a rainy-normal year, despite the differences in the total quantity of precipitation supports the argument that the distribution of precipitation is very important in the production of phytomass. In this regard, González and Páez (1995) point out that the response to water stress depends on the species and the state of development of the plant at the time when rainfall occurs. 
The root/shoot ratio shows similar values among the pluviometric regimes ( 0.28 to 0.55 ), with the exception of the N-te, which was significantly higher (1.64); the value of the reference treatment was the same as that the rainynormal year. This similarity of the ratio in the majority of the conditions studied indicates that normally there would be a greater proportion of resources destined to the shoots than to the roots and that $H$. murinum is capable of adjusting the proportions of phytomass assigned to these structures. The high values of the normal-early year are due to the fact that these plants do not complete their cycle or produce fruits, because of which all of their resources are directed to the growth of shoots. Li et al. (2008) points out that climatic variables explain around $50 \%$ of the changes in the root/shoot ratio of plants in non-degraded pastures.

\section{Reproductive biomass production}

It should be noted that the dry years, with early and late distribution, and the normal-early year did not reach reproductive development; consequently they are not included in the respective analysis. All the variables on the quantity of measured reproductive growth that completed their reproductive cycle (Table 2) had lower values than those obtained from the reference treatment (Table 1), which would indicate that any water restriction reduces the reproductive structures produced by $H$. murinum $\mathrm{L}$. The behavior was similar in rainy years with both late and normal distribution, while in comparison to the late distributions with different quantities of total precipitation, it was demonstrated that there are differences in all the measured variables, with the normal year being higher.

Kokubun et al. (2001) observed that a water deficit in the flowering phase of soya (Glycine max (L.) Merr.) reduced the contribution of assimilates to floral structures, determining a higher number of floral abortions and damage to pistils and stamens. Something similar occurred in $H$. murinum in those treatments that did not produce fruits, the similar results obtained in the rainy years indicate that the changes could be attributable, on the one hand, to factor related to the production and transfer of assimilates, and on the other hand, to the growth and development of seeds, rather than a change in the potential number of seed sites, which coincides with the results of other works (Johnston et al., 2003).

Upon analyzing seed quality, it was observed that the values of the normal-late year were the highest in the number of seeds and weight of annexes (Table 2); in the case of rainy years, although they did not differ among them, they tend to produce more empty seeds and with higher weight of annexes in the late distribution. Considering the relative proportion of annexes and base seeds in relation to total fruit weight (Figure 3) it was demonstrated that the late distributions present higher proportions of annexes, with those from the normallate year being highest. Nevertheless, in terms of the proportion of seeds, the rainy-normal year had the highest values the normal-late year had the lowest. In the plants without water restriction, there was a high production of seeds (Table 1 ) with $27 \%$ of empty seeds.

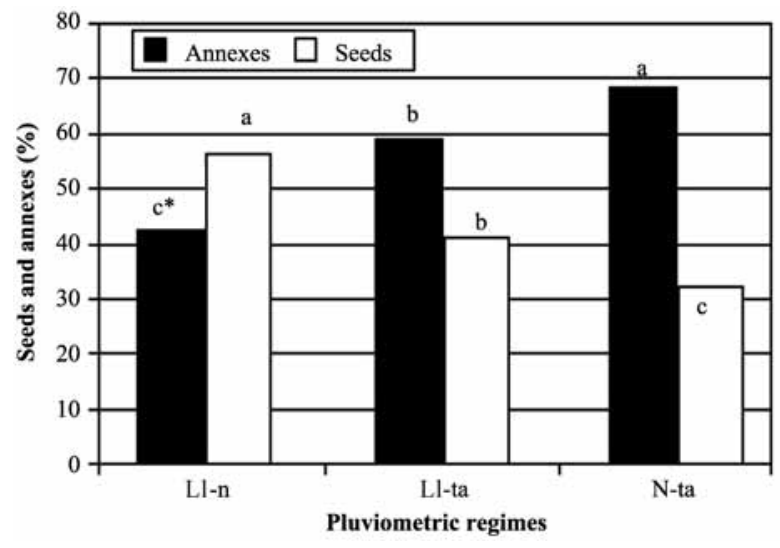

* Different letters over columns of the same color indicate significant differences among treatments $(\mathrm{P} \leq 0.05)$.

Figure 3. Annex and seed percentage in relation to total fruit weight from Hordeum murinum according to rainfall levels and distribution Ll-n rainy normal, LIta rainy late, $\mathrm{N}$-ta normal late.

Table 2. Phytomass reproductive components: floral stem (FS), total seed (TS), full and empty seeds number; fruit (seed plus annexes), seed (S) and annex weight of Hordeum murinum according to amount and distribution of annual rainfalls.

\begin{tabular}{llcccccc}
\hline Treatments & FS & $\begin{array}{c}\text { Fruit } \\
\text { weight }\end{array}$ & TS & S & $\begin{array}{c}\text { Full } \\
\text { seeds }\end{array}$ & $\begin{array}{c}\text { Empty } \\
\text { seeds }\end{array}$ & $\begin{array}{c}\text { Peso } \\
\text { annexes }\end{array}$ \\
\hline & $\mathrm{N}^{\mathrm{o}}$ & $\mathrm{mg}$ & $\mathrm{N}^{\mathrm{o}}$ & $\mathrm{mg}$ & $\mathrm{N}^{\mathrm{o}}$ & $\mathrm{N}^{\mathrm{o}}$ & $\mathrm{mg}$ \\
Rainy-normal (Ll-n) & $1.1 \mathrm{~b}^{*}$ & $58 \mathrm{~b}$ & $16.7 \mathrm{~b}$ & $33 \mathrm{~b}$ & $11.6 \mathrm{~b}$ & $5.5 \mathrm{~b}$ & $25 \mathrm{~b}$ \\
Rainy-late (Ll-ta) & $0.9 \mathrm{~b}$ & $88 \mathrm{~b}$ & $19.7 \mathrm{~b}$ & $37 \mathrm{~b}$ & $11.7 \mathrm{~b}$ & $7.9 \mathrm{~b}$ & $51 \mathrm{~b}$ \\
Normal-late (N-ta) & $1.9 \mathrm{a}$ & $210 \mathrm{a}$ & $45.0 \mathrm{a}$ & $72 \mathrm{a}$ & $30.9 \mathrm{a}$ & $14.1 \mathrm{a}$ & $142 \mathrm{a}$ \\
\hline
\end{tabular}

* Different letters in the column indicate significant differences among treatments $(\mathrm{P} \leq 0.05)$. 
Precipitation and low temperatures during flowering in populations of Hordeum spontaneum and $H$. vulgare determined positive correlations between the crosspollination rate and annual average precipitation and negative correlations between the former and cold temperatures during flowering (Abdel Ghani et al., 2002). On the other hand, according to Egli (2004) water stress during the seed development of oats and other species cuts this period and reduces production. As well, water stress accelerates foliar senescence in Avena sativa L. It can then be considered that the normal-late year provides the most favorable conditions for the growth of reproductive structures (fruits), but rainy years favor the movement of assimilates to the seeds.

The pluviometric regime did not affect the capacity for germination, total viability or the estimated seed size (Table 3), and their values did not differ from those presented by the treatment without water restriction. It could be concluded with this that the persistence of the species is assured under unfavorable conditions as argued by Abdel Ghani et al. (2002) for Hordeum spontaneum and $H$. vulgare. Similar results were obtained by Herrera et al. (2008) in Chloris cucullata and C. subdolichostachys where the percentage of full and dormant seeds changed among years with different distributions of precipitation, but without altering viability.

It has been established that once the number of fruiting sites is fixed, water availability will determine the fullness of seeds, both in terms of production and transportation of new assimilates and the transfer of assimilates from reserve (Johnston et al., 2003). This explains the fact that the reference treatment had the lowest proportion of empty seeds, that the proportion of seeds was higher in the normal rainy year, that the proportion of annexes was higher in late years and that all the seeds produced presented high percentages of germination.

The calculated indicators of reproductive growth (Table 3) show that the pluviometric regimes that complete this phase presented changes in the assignment of resources for the production of disseminules. Thus, the normal-late year was significantly more favorable with the highest indices, both in reproductive efficiency (REI) and the reproductive index (RI), which indicates that a greater quantity of assimilates are destined to form seeds than in the other treatments, with the exception of the reference, which is also reflected in values of the quantity and weight of the seeds obtained (Table 2).

Works with $H$. spontaneum and A. sterilis (Volis, 2007) using gradients of aridity that included quantity and distribution of precipitation showed that increasing aridity reduced the maturation time of the seeds and that there was a negative correlation between the size and number of seeds, a tendency similar to what was shown in the normal-late year.

All of this shows the different strategies that $H$. murinum uses to assign its resources to the diverse components of reproductive growth according to the pluviometric regime that is present, and consequently allows for understanding not only its great productive potential but also its great plasticity, its tolerance to adverse conditions and its great capacity for persistence in the annual range of the semi-arid Mediterranean zone. Something similar was argued by Aronson et al. (1993) for some annual desert species, where changes in reproductive biomass in the context of water stress is manifested in both the number and size of seeds, which allows for survival under critical conditions.

\section{Observations of phenological development}

$H$. murinum did not complete its life cycle in the dry years and the normal-early years, while the reference treatment without a water deficit had the longest life cycle and the longest reproductive stage. In the treatments where the cycle was completed a marked separation of the vegetative phenophases was observed. The duration of this stage was similar in all the treatments (Table 4); nevertheless, it can be noted that the rainy-late year had a more prolonged emergence even though its initiation was simultaneous to the other treatments (10 days after seeding). The normal-late year presented a longer tillerage phase than the other treatments and did not have a defined foliation phase.

Table 3. Germination and viability percentage, mean seed size and values of reproductive efficiency: reproductive index (RI) and index of reproductive efficiency (REI) of Hordeum murinum according to annual rainfall amount and distribution.

\begin{tabular}{|c|c|c|c|c|c|}
\hline Treatments & Germination & Viability & Size & REI & RI \\
\hline & 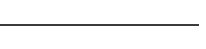 & 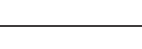 & $\mathrm{mm}$ & & \\
\hline Rainy-normal (Ll-n) & $95 a^{*}$ & $97 a$ & $5.6 a$ & $6.98 b$ & $0.03 \mathrm{~b}$ \\
\hline Rainy-late (Ll-ta) & 93a & $96 a$ & $6.1 \mathrm{a}$ & $4.22 \mathrm{~b}$ & $0.02 b$ \\
\hline Normal-late (N-ta) & $98 a$ & 99a & $5.8 \mathrm{a}$ & $21.70 \mathrm{a}$ & $0.12 \mathrm{a}$ \\
\hline
\end{tabular}

* Different letters in the same column indicate significant differences among treatments $(\mathrm{P} \leq 0.05)$. 
Table 4. Phenological stage duration (days) of Hordeum murinum, according to annual rainfall amount and distribution.

\begin{tabular}{lrrrrrrrrr}
\hline Year & Em & Fol & Mac & Fol-til & $\begin{array}{c}\text { Stem } \\
\text { elong }\end{array}$ & Flo & Seed & Mat & Senes \\
\hline Rainy-normal & 7 & 20 & 7 & 31 & 30 & 37 & 35 & 35 & 46 \\
Rainy-late & 25 & 5 & 7 & 25 & 26 & 17 & 12 & 35 & 29 \\
Normal-early & 15 & 10 & 21 & 14 & $*$ & $*$ & $*$ & $*$ & 35 \\
Normal-late & 10 & 29 & 32 & 0 & 27 & 27 & 23 & 23 & 31 \\
Dry-early & 17 & 14 & 21 & 10 & 17 & $*$ & $*$ & $*$ & 58 \\
Dry-late & 11 & 20 & 15 & 17 & 25 & $*$ & $*$ & $*$ & 26 \\
Reference & 8 & 23 & 20 & 15 & 44 & 27 & 27 & 54 & 46 \\
\hline
\end{tabular}

* The totality of the plants did not present the phenological phases, only the beginning of the stages was evidenced.

Em: emergence, Fol: foliation, Til-tillering, Fol-til: foliation of tillerage, Stem elong: Stem elongation, Flo: flowering, Seed: seeding, Mat: maturation, Senes:senescence.

According to Egli (2004) water stress during seed development of oats and other species cuts the cycle and reduces production. It was also observed that water stress in A. sativa accelerates foliar senescence.

This species was able to express the total of its growth potential in the tested rainy years and given that its response is very similar to the reference treatment, it could indicate a greater competitive potential in relation to other species of this range, such as Bromus berteroanus Colla and Avena barbata Pott. which can only present their potential when there are no water restrictions (Olivares et al., 2006; Castellaro and Squella, 2006). Nevertheless, in exceptionally rainy years, these two species have advantages given their potential for growth and development has been higher than what is obtained with pluviometric regimes typical of the area.

The duration of the reproductive stage, considered from stem elongation, was the most affected by the pluviometric regimes and the phenophases showed diverse degrees of superimposition in all the treatments. The year normal-late year had the shortest total duration of the cycle, suggesting that water availability is a determinant of this duration (Table 4).

In general it was observed that without water restriction the species extends its cycle and has a considerably longer seed maturation phase than with the other treatments. The stem elongation phase was also longer and the senescence phase was one of the latest to initiate.

The alterations observed in the duration of the phenophases seems to be directly linked to both the quantity and timing of rainfalls (Figure 1). Thus, the prolongation of the emergence period of the rainy-late year is explained by the fact that between May and June there was little availability of water, which, added to the low winter temperatures, impeded the initial development of the root. On the other hand, maximum precipitation occurring in August shortened foliation in the normal distribution and prolonged this phase in rainy-late distribution because of a condition of hypoxia or anoxia in the soil, as has been shown in other species (Drew, 1997).

Although the duration of the total life cycles were similar, the rainy years showed different durations of the phenophases in accordance with the distribution of rainfall, particularly in emergence, foliation, flowering, seed formation and senescence. This could be because the water deficit was presented in one case at the beginning and the other at the end of the pluviometric cycle, affecting different development stages in the two treatments. The dry years tested, independent of the distribution, did not allow for reaching the reproductive stage, thus the amount of precipitation will alter the duration of the phases, shortening or extending them according to the quantity of available water.

Although $H$. murinum shortened its phases in the normal-late year in adaptation, it developed a longer vegetative stage in comparison to the reproductive stage, with which it would have a greater probability of generating the photosyntates that assured the higher production of seeds that was observed by Johnston et al. (2003) when this species is submitted to stress by cuts. In contrast, a lower quantity of precipitation determined that some phases were not completed, as occurred in the dry-early and dry-late years.

\section{CONCLUSIONS}

It can be concluded that:

Hordeum murinum produces a greater quantity of total dry material with more favorable water regimes in terms of the quantity of precipitation and a better distribution.

The distribution of precipitation appears to be the most important determining factor in the production of seeds of this species. 
Seed quality, expressed in the capacity to germinate and viability, is not affected by the pluviometric regime of the semi-arid Mediterranean region.

The species assigns a greater part of its reproductive resources to seed production, which gives it more potential for adaptation to distinct water conditions.

In the dry years with early or late distribution of rainfalls and early rainy years there is no possibility of re-seeding for this species.

\section{RESUMEN}

\section{Efecto delacantidady distribucióndelasprecipitaciones} en el crecimiento y desarrollo de Hordeum murinum $\mathbf{L}$.

Se evaluó el desarrollo de plantas de Hordeum murinum sometidas a regímenes pluviométricos simulados en invernadero frío. En un diseño de bloques completos al azar con cinco repeticiones, se establecieron tratamientos según cantidad y distribución de las precipitaciones reales del secano de la Región Metropolitana, Chile: lluviosotardío, normal-tardío, seco-temprano, lluvioso-normal, normal-temprano, seco-tardío y uno de referencia sin restricción hídrica. Se sembraron semillas del año en macetas con suelo desinfectado dejando cinco plántulas uniformes en tamaño y sanidad. Las lluvias simuladas se aplicaron según el calendario del año seleccionado. Se evaluó la producción de fitomasa aérea y radical, la cantidad de tallos florales, de frutos y semillas y su peso total; la proporción de anexos y el llenado de las semillas, su viabilidad y capacidad germinativa. En los años secos el ciclo vital fue más breve y hubo menor producción de materia seca aérea; en los lluvioso-normal y normal-tardío se presentó un crecimiento radical similar, insinuando que es más determinante la distribución de las precipitaciones. Todos los parámetros de crecimiento reproductivo en los regímenes usados fueron inferiores a los de referencia sin restricción hídrica. Los años secos y el normal-temprano no produjeron semillas. La calidad de semillas producidas en el resto de los tratamientos no fue afectada por los regímenes pluviométricos. Se concluye que $H$. murinum destina gran parte de sus recursos a producción de semillas sin alterar su calidad y que las distribuciones tardías son más determinantes para esta producción.

Palabras clave: régimen pluviométrico, eficiencia reproductiva, poacea naturalizada.

\section{LITERATURE CITED}

Abdel Ghani, A.H., H.K.Parziez, and H.H.Geiger . 2002. Estimation of outcrossing rate in Hordeum spontaneum and barley landraces from Jordan. Heredity 41:49-62.
Acuña, H. 1978. Relaciones entre productividad primaria y pluviometría en una pradera anual de la zona mediterránea semiárida de Chile. 60 p. Tesis Mg. Sc. Universidad de Chile, Facultad de Ciencias Agrarias y Forestales, Santiago, Chile.

Aronson, J., A. Kigel, and A. Shmida. 1993. Reproductive allocation strategies in desert and Mediterranean populations of annual plants grown with and without stress. Oecologie 93:336-342.

Castellaro, G., y F. Squella. 2006. Modelo simple de simulación para la estimación del crecimiento, fenología y balance hídrico de praderas anuales de clima mediterráneo. Agric. Téc. (Chile) 66:271-282.

Drew, M. 1997. Oxygen deficiency and root metabolism: Injury and acclimatation under hypoxia and anoxia. Annu. Rev. Plant Physiol. Mol. Biol. 48:223-250.

Egli, D.B. 2004. Seed- fill duration and yield of grain crops, Advances in Agronomy. 83:243-278.

González, M., y A. Páez. 1995. Efecto del déficit hídrico aplicado durante diferentes etapas de desarrollo de Panicum maximun Jacq. Maracaibo, Venezuela, Rey. Facultad Agronomía (Luz) 12:79-93. Available at http://www.revfacagronluz.org.ve/v13_1/v131z008. html (Accessed 11 January 2003).

Gutiérrez, J. 1993. The effect of water, nitrogen and human-induced desertification on the structure of ephemeral plant communities in the Chilean coast desert. Rev. Chil. Hist. Nat. 66:337-344.

Herrera, F., W.R. Ocumpaugh, J.A. Ortega,J.Lloyd-Reilley, G.A. Rasmussen, and S. Maher. 2008. Environmental influences on seed quality of windmillgrass ecotypes in South Texas. Agronomy J. 10:1255-1210.

Huang, B., and H. Gao. 2000. Root physiological characteristics associated with drought resistance in tall fescue cultivars. Crop Sci. 40:196-203.

Huang, B., and J. Fry. 1998. Root anatomical, physiological and morphological responses to drought stress for tall fescue cultivars. Crop Sci. 38:1017-1022.

ISTA. 2007. International Rules for Seed Testing. Version 2007. International Seed Testing Association, Switzerland.

Jara, P.A., G. Arancio, R. Moreno, y M. Carmona. 2006. Factores abióticos que influencian la germinación de seis especies herbáceas de la zona árida de Chile. Rev. Chil. Hist. Nat. 79:309-320.

Johnston, M., A. Olivares, V. García de Cortazar, y X. Contreras. 1998. El banco de semillas del suelo y su respuesta a regímenes pluviométricos simulados. I. Comunidad de terófitas del Mediterráneo semiárido. Av. Prod. Anim. 23:45-54. 
Johnston, M., A. Olivares, y J. Laura. 2003. Estrategias reproductivas de terófitas del Mediterráneo semiárido como respuesta a tratamientos de corte. Phyton 64:267-280.

Johnston, M., A. Olivares, y C. Gutiérrez. 2005. Efecto del régimen pluviométrico de la Región Metropolitana en la producción y calidad de semillas de Bromus berteroanus Collar. Agro Sur 33:01-08.

Kokubun, M., S. Shimada, and M. Takahashi. 2001. Flower abortion caused by preanthesis water deficit is not attributed to impairment of pollen in soybean. Crop Sci. 41:1517-1521.

Li, Y., T. Luo, and Q. Lu. 2008. Plant height as a simple predictor of the root to shoot ratio: Evidence from alpine grasslands on Tibetan Plateau. J. Veget. Sci. 19:245-252.

Lorenzetti, F. 1993. Achieving potential herbage seed yield in species of temperate regions. Vol. 2. p. 1621-1628. Proceedings XVII International Grassland Congress, Palmerston North, Hamilton, Lincoln, New Zealand. International Grassland Association. Palmerston North, New Zealand.

Minitab Inc. 2000. Meet Minitab: Release 13 for Windows ${ }^{\circledR}$ 95/98/2000 and Windows NTTM. Minitab, USA.

Montgomery, D. 1991. Diseño y análisis de experimentos. 589 p. Iberoamericana, Madrid, España.
Olivares, A., M. Johnston, y C. Beck. 1997. Emergencia de especies de la pradera natural de tipo mediterráneo en relación con la humedad del suelo. Av. Prod. Anim. 22:23-29.

Olivares, A., M. Johnston, y X. Contreras. 1998. Régimen pluviométrico del secano interior de la Región Metropolitana. Av. Prod. Anim. 23:35-43.

Olivares, A., M. Johnston, y E. Salas. 2004. Distribución de la precipitación y producción de semillas de alfilerillo, Erodium moschatum (L.) L’Hér. Agric. Téc. (Chile) 64:251-263.

Olivares. A., M. Johnston y C. Gutiérrez. 2006. Crecimiento y desarrollo de Bromus berteroanus Colla. sometido a diferentes regímenes pluviométricos. Agric. Téc. (Chile) 66:166-173.

Rotundo, L., P. A. Cipriotti, and P. E. Gundel. 2006. Morphological and growth responses to water stress of two sub-populations of Bromus pictus from soils with contrasting water availability. Rev. Chil. Hist. Nat. 79:65-74.

Volis, S. 2007. Correlated patterns of variation in phenology and seed production in populations of two annual grasses along an aridity gradient. Evol. Ecol. 21:381-393.

Warringa, J., R. De Viseer, and A. Kreuzer. 1998. Seed weight in Lolium perenne as affected by interactions among seeds within the inflorescence. Ann. Bot. (London) 82:835-841. 


\title{
PREDICTION OF THE COMPOSITION OF FRESH PASTURES BY NEAR INFRARED REFLECTANCE OR INTERACTANCE-REFLECTANCE SPECTROSCOPY
}

\author{
Daniel Alomar1*, Rita Fuchslocher, José Cuevas, Rodrigo Mardones, and Emilio Cuevas
}

\begin{abstract}
Fast and precise analytical tools can contribute to optimize pasture management decisions. This work was carried out to evaluate the potential of one such technique, near infrared spectroscopy (NIRS), to predict the nutritional value of pastures without previous drying of the samples, comparing two forms of collecting the spectra: reflectance, or interactance-reflectance (fiber optic probe). Samples $(n=107)$ from different swards were taken across the humid and temperate regions (Los Ríos and Los Lagos) of southern Chile. Once their spectra were collected, dry matter (DM) and several chemical constituents, such as crude protein (CP), metabolizable energy (ME), neutral (NDF) and acid detergent fiber (ADF), soluble carbohydrates (SC), soluble crude protein (SCP) and neutral detergent insoluble N (NDFIN), were determined as reference data. Calibrations were developed and the best ranked were selected (by cross-validation) according to a lower standard error of cross validation ( $\left.\mathrm{SE}_{\mathrm{CV}}\right)$ and a higher determination coefficient of cross validation $\left(\mathrm{R}^{2}{ }_{\mathrm{CV}}\right)$. Calibrations in the reflectance mode, for $\mathrm{DM}$ and $\mathrm{CP}$, reached a high $\mathrm{R}^{2}{ }_{\mathrm{CV}}$ (0.99 and 0.91, respectively) and a $\mathrm{SE}_{\mathrm{CV}}$ (6.5 and $18.4 \mathrm{~g} \mathrm{~kg}^{-1}$ ). Equations for ADF, SCP and ME were ranked next, with $\mathrm{R}^{2} \mathrm{CV}$ of $0.87,0.84$ and 0.82 , respectively, and $\mathrm{SE}_{\mathrm{CV}}$ of $15.88 \mathrm{~g} \mathrm{~kg}^{-1}, 15.45 \mathrm{~g} \mathrm{~kg}^{-1}$ and $0.34 \mathrm{Mj} \mathrm{kg}^{-1}$. Equations for NDF, SC and NDFIN, with $\mathrm{R}^{2}{ }_{\mathrm{CV}}$ of $0.78,0.77$ and 0.61 , respectively, and $\mathrm{SE}_{\mathrm{CV}}$ of $35.57,94.54$ and $1.89 \mathrm{~g} \mathrm{~kg}^{-1}$, respectively, are considered unreliable for prediction purposes. Interactance-reflectance, on the other hand, resulted in poorer equations for all fractions.
\end{abstract}

Key words: pasture composition; NIR prediction; near infrared reflectance spectroscopy, fresh pastures, fiber optics.

\section{INTRODUCTION}

Near infrared reflectance spectroscopy (NIRS) has been widely used as a fast, reliable and multiple method for evaluating the quality of forages, as well as other agricultural products. This technique is based on the absorption properties of the sample in the near infrared (NIR) electromagnetic region, explained by the chemical bonds present in the specimen being scanned, particularly those bonds involving hydrogen (Deaville and Flinn, 2000). The spectrum resulting from the molecular vibration mechanisms can be complicated by a multitude of factors, but with current capabilities, even when the entire spectrum is not understood, it is still possible to extract useful information by employing multivariate calibration methods to construct empirical models that relate relevant spectral variability of a population of samples to its chemical nature (Miller, 2001).

${ }^{1}$ Universidad Austral de Chile, Facultad de Ciencias Agrarias, P.O. Box 567, Valdivia, Chile.

"Corresponding author (dalomar@uach.cl).

Received: 10 January 2008.

Accepted: 12 May 2008.
In the case of forages and other materials of agricultural origin, most of the NIRS work has been performed with dry samples, as the high water content in the typical "natural" condition of fresh pasture samples presents some difficulties. Water, quantitatively the most important constituent in fresh forages and other agricultural materials, can be a challenge in the laboratory processing of fresh samples, imposing difficulties in grinding and affecting particle size and shape. Water can also affect the reliability of the detectors in the upper NIR range (Williams, 2001), as it provokes strong absorption signals that overlap and obscure other spectral features and can cause non-linear responses (Reeves, 2000). On the other hand, if samples could be scanned in their fresh, undried state, and their composition or nutritional value predicted within acceptable limits, an approach for fast and reliable predictions in the field could develop, as the industry devises more portable NIR equipment and computers, without sacrificing accuracy. Alternatively, samples arriving at the laboratory could be instantly predicted without the delay of the drying process, which can also alter chemical bonds, affecting the spectrum and, as a result, the perception of some compositional fractions 
(Alomar et al., 1999); Alomar et al., 2003; Deinum and Maassen, 1994. Natural samples, as fresh forage, can be scanned in special rectangular cells, which present a large sample area exposed to NIR radiation in comparison to traditional circular cells. The forage couvette can be inserted in a transport module that allows the sample to be scanned and its NIR reflectance spectrum collected across the long axis of its surface, as the cell is displaced by the mechanism. An alternative to the above is to apply fiber optics technology, which could be interesting when operating under environmental conditions not suitable for sensitive equipment (Osborne et al., 1993). Fiber optics could be attractive for work under field conditions, but the performance of technology on fibrous materials needs to be evaluated. One problem is that optic probes normally have a small scanning area, especially if compared with a large forage cell. Although a higher sampling error could be produced, this could be partially overcome by taking several readings for each sample, assuming that errors occur at random.

The objective of the present study was to assess the potential of predicting the nutritional value of different types of pastures in a fresh, undried condition by near infrared technology, developing calibrations with the spectra taken by reflectance on a large forage cell and by interactance reflectance, by means of a fiber optics probe.

\section{MATERIALS AND METHODS}

\section{Pasture sampling}

One hundred and seven samples of different types of swards were collected from different paddocks in 13 farms at different locations ( 39 and $42^{\circ} \mathrm{S}, 72^{\circ} \mathrm{W}$ ) in the temperate, humid Los Ríos and Los Lagos Regions, Southern Chile. Samples were hand clipped at $5 \mathrm{~cm}$ from soil, from March 2001 to May 2002, approximately at 1 to 2 wk intervals, covering different seasons, growth stages, predominant species, geographical positions, soil types and other factors that could account for sources of variation in nutritional value and spectral features. The forage obtained represented mixed permanent swards (comprising different proportions of grasses of the genera Lolium, Agrostis, Holcus, Bromus and Dactylis), but also legumes such as alfalfa (Medicago sativa L.) and clovers (mostly Trifolium pratense L. and T. repens L.) and annual lawn of oats (Avena sativa L.) or barley (Hordeum vulgare L.). Several broad-leaved species were also present in different proportions.

\section{Spectra collection}

Fresh samples, 1 to $2 \mathrm{~kg}$, were taken to the laboratory, cut to 2 to $3 \mathrm{~cm}$ with hand shears, thoroughly homogenised by hand and scanned in a Foss-NIRSystems 6500 scanning monochromator (Silver Springs, Maryland, USA) with accessories (as below) from the same manufacturers, all controlled by a personal computer and software NIRS 3 from Infrasoft International (ISI, Port Matilda, Pennsylvania, USA). Optical data, transformed to microabsorbance units $(\log 1 / \mathrm{R})$, were stored in suitable files. Spectra were collected either in reflectance, with a large rectangular cell with a quartz window providing $60 \mathrm{~cm}^{2}$ of sampling area (Part Number NR-7080, and inserted in a transport module (Part Number NR-6511), or in interactance reflectance with an optic fiber-optic probe (Part Number NR-6775), comprising a double bundle of concentric silica fibers (210 inner illuminators/210 external collectors of diffuse reflected radiation). The probe containing the fiber bundle is protected by an external steel jacket. In the case of the reflectance readings, three scans were taken by rearranging the sample in the cell, averaged and stored. In the case of the interactance reflectance option, samples were packed in opaque polyvinyl chloride (PVC) tubes $(25 \times 11 \mathrm{~cm})$ with same material caps at both ends and three perforations along main axis, enabling the fiber probe to be tightly introduced to irradiate the sample and collect the readings. In this way, three readings were collected for each sample and stored as described above. As the probe used has the option to adjust the distance between the end of the fiber bundle and the end of the external jacket (path length to the sample), spectra were taken at distances of $0,0.5,1,3$ and $5 \mathrm{~mm}$. Accessories for two modes of scanning samples were attached consecutively to the same monochromator as each new batch of new collected samples were scanned. Two events that took place along the experimental period are worth mentioning, as they affected spectral data and eventually the calibrations obtained: the first was a change of the light source (lamp) in November 2001, and the second a routine adjustment in the monochromator in January 2002.

\section{Chemical analysis}

After spectra were collected, samples were dried in a forced-air oven at $60{ }^{\circ} \mathrm{C}$ for $48 \mathrm{~h}$, ground in a laboratory mill (Thomas Wiley model 4, Arthur Thomas \& Co. Philadelphia, Pennsylvania, USA) with a $1 \mathrm{~mm}$ screen, and analysed for residual dry matter (DM) using oven at $105^{\circ} \mathrm{C}$ for $12 \mathrm{~h}$, crude protein (CP) by Kjeldahl and crude fiber (CF), following AOAC (1996) procedures (method 978.10); soluble crude protein (SCP) after Licitra et al. (1996), neutral detergent (with sodium sulfite and alpha amylase) fiber (NDF) after Van Soest et al. (1991), acid detergent fiber (ADF) after AOAC (1996) method 973-18, neutral detergent insoluble nitrogen (NDFIN), combining methods for NDF with Kjeldahl, as above; and digestible 
organic matter in dry matter (DOMD) by the two-stages in vitro digestibility method of Tilley and Terry (1963), modified by incubating (both stages) in an oven at 39 ${ }^{\circ} \mathrm{C}$ in closed flasks. DOMD was in turn used to estimate metabolizable energy (ME) according to a regression on in vivo values developed previously in our laboratory (Garrido and Mann, 1981).

\section{Calibrations}

Regression equations were adjusted relating spectral data to fractions determined by the reference methods. Calibration models were developed with the software WinISI II from Foss, NIRSystems (Silver Spring, MD), testing different mathematical treatments of the spectra (differentiation order, subtraction gap, smoothing interval), with or without applying Standard Normal Variance (SNV) and Detrend for scatter correction of the spectra. SNV scales each spectrum to have a standard deviation of 1.0 to help reduce particle size effects, and Detrend removes the linear and quadratic curvature of each spectrum (ISI, 1999). The regression method chosen was modified partial least squares.

The same calibration approach was used for spectra collected in reflectance (transport module) and interactance reflectance (fiber optics). However, while in the first group the full spectra were used $(400-2500 \mathrm{~nm})$, in the second the spectra were trimmed, excluding the range of $400-1100 \mathrm{~nm}$, since the detectors of the interactance reflectance probe are not suitable for that segment.

Cross validation was performed by dividing the set of samples in groups, to adjust the maximum number of terms (to avoid overfitting) and to select the best equations, i.e. those having a lower standard error of cross validation (SECV) and a higher determination coefficient of the cross validation $\left(\mathrm{R}^{2} \mathrm{CV}\right)$. Four cross validation groups and two passes of elimination of outliers were defined. A critical $\mathrm{T}$ value of 2.5 was set for "T outliers", i.e., samples with abnormally high residuals of predicted versus reference values.

\section{RESULTS AND DISCUSSION}

\section{Chemical composition}

The compositional data for the samples (Table 1) showed a wide variability in composition of analytical data, which confirms the important differences among sampled pastures.

Values for DM in the range of $100 \mathrm{~g} \mathrm{~kg}^{-1}$ reflect full vegetative growth, typical of mid to late winter. This is also confirmed by unusually high contents of CP, above $330 \mathrm{~g}$ $\mathrm{kg}^{-1} \mathrm{DM}$, for this type of plant material. On the other hand, samples from mature swards are also present, with protein contents around or below $100 \mathrm{~g} \mathrm{~kg}^{-1} \mathrm{DM}$ and DM contents in excess of $300 \mathrm{~g} \mathrm{~kg}^{-1}$. A broad distribution is desirable when a set of samples is selected for the development of NIR calibrations, as a way to have a better representation of the universe to be predicted subsequently in routine analysis.

\section{Spectra}

The spectra from samples scanned by reflectance (average of three readings) are presented in Figure 1. The three blocks of parallel spectra that can be seen clearly apart (Figure 1a), are explained by the adjustments on the equipment, as explained earlier. The important base line shift, impressive as it looks, does not necessarily imply that relevant spectral information cannot be extracted by suitable means. If the combined treatments of standard normal variate (SNV) and Detrend are applied, the shifts are no longer apparent (Figure 1b) and some variability appears in different bands. Information can be subsequently refined by mathematical treatments, such as derivatives and smoothing. After applying a first derivative (subtraction) of the spectral data, over a gap of five data points and a smoothing of segments of five data points (Figure 1c), lines tend to lie close together, except in bands where differences are more apparent. This seems to be the case for the segment of 2050 to $2060 \mathrm{~nm}$ (Figure 1c, insert), where curves in the lower position (samples 89, 91, 102) had the lowest CP $(83.9,81.2$ and $119.0 \mathrm{~g}$

Table 1. Composition of samples obtained by laboratory reference methods.

\begin{tabular}{lrrr}
\hline Fraction & \multicolumn{1}{c}{ Range } & Average & Standard deviation \\
\hline Dry matter, g kg-1 & $92.10-359.80$ & 182.20 & 53.60 \\
Crude protein, g kg-1 DM & $81.20-373.20$ & 205.50 & 65.80 \\
Metabolizable energy, Mj kg-1 DM & $8.82-12.47$ & 11.00 & 0.79 \\
Neutral detergent fiber, g kg-1 DM & $224.30-656.60$ & 449.80 & 77.10 \\
Acid detergent fiber, g kg-1 DM & $162.70-375.80$ & 263.00 & 45.90 \\
Soluble protein, g kg-1 DM & $20.90-209.80$ & 91.80 & 40.00 \\
Neutral detergent insoluble nitrogen, g kg-1 DM & $2.10-20.60$ & 7.50 & 3.50 \\
\hline
\end{tabular}

DM: dry matter. 
$\mathrm{kg}^{-1} \mathrm{DM}$ respectively) while those in the upper position $(17,29,33$ and 34), had the highest content (355.5, 373.2, 257.2 and $260.6 \mathrm{~g} \mathrm{~kg}^{-1} \mathrm{DM}$ respectively).

Interactance reflectance spectra also showed a base line shift as a result of fixing and regulations on the equipment (Figure 2a). This is no longer apparent after applying a scatter correction treatment (Figure 2b). Besides, changing light aperture produced differences in absorption peaks, with a weaker signal for $5 \mathrm{~mm}$ distance (Figure 3), which means that reflected light was more attenuated when it reached collecting fibers.

\section{Calibrations}

After testing several mathematical treatments, the best calibrations were selected according to their cross validation parameters. Table 2 shows the statistics of the best calibrations for the different fractions analysed and with the spectra of samples scanned by reflectance and interactance reflectance.

The selected calibrations were obtained with different math treatments. While for reflectance spectra all fractions were best predicted when calibrations were performed with a first or second order derivative, for interactance reflectance the best equations were developed with the "raw" spectra (with the exception of NDF) and a smoothing for four or five data points. In general, spectra taken by reflectance produced better results than those taken by interactance reflectance for all fractions, with the exception of NDIN, which was similar. The equations obtained in reflectance for DM, CP and ADF showed the highest statistics for certainty, with $\mathrm{R}^{2} \mathrm{CV}$ of 0.9 or higher, and a SECV lower than a third of the standard deviation (SD) of reference data. This relation between SECV and SD has been proposed as useful for evaluating an equation, which can be considered as reliable for prediction work when SD is more than three times higher than the SECV (Kennedy et al., 1996). Another criterion that can be applied is the ratio between SECV and the average of reference data for a given fraction, and in general the best equations also tended to show values below 0.1 for this relation. This was the case for DM (0.041), CP (0.082) and ADF (0.054), in the reflectance mode. For ME however, although both equations ended with a SECV of less than $5 \%$ of the reference data average, they can not be
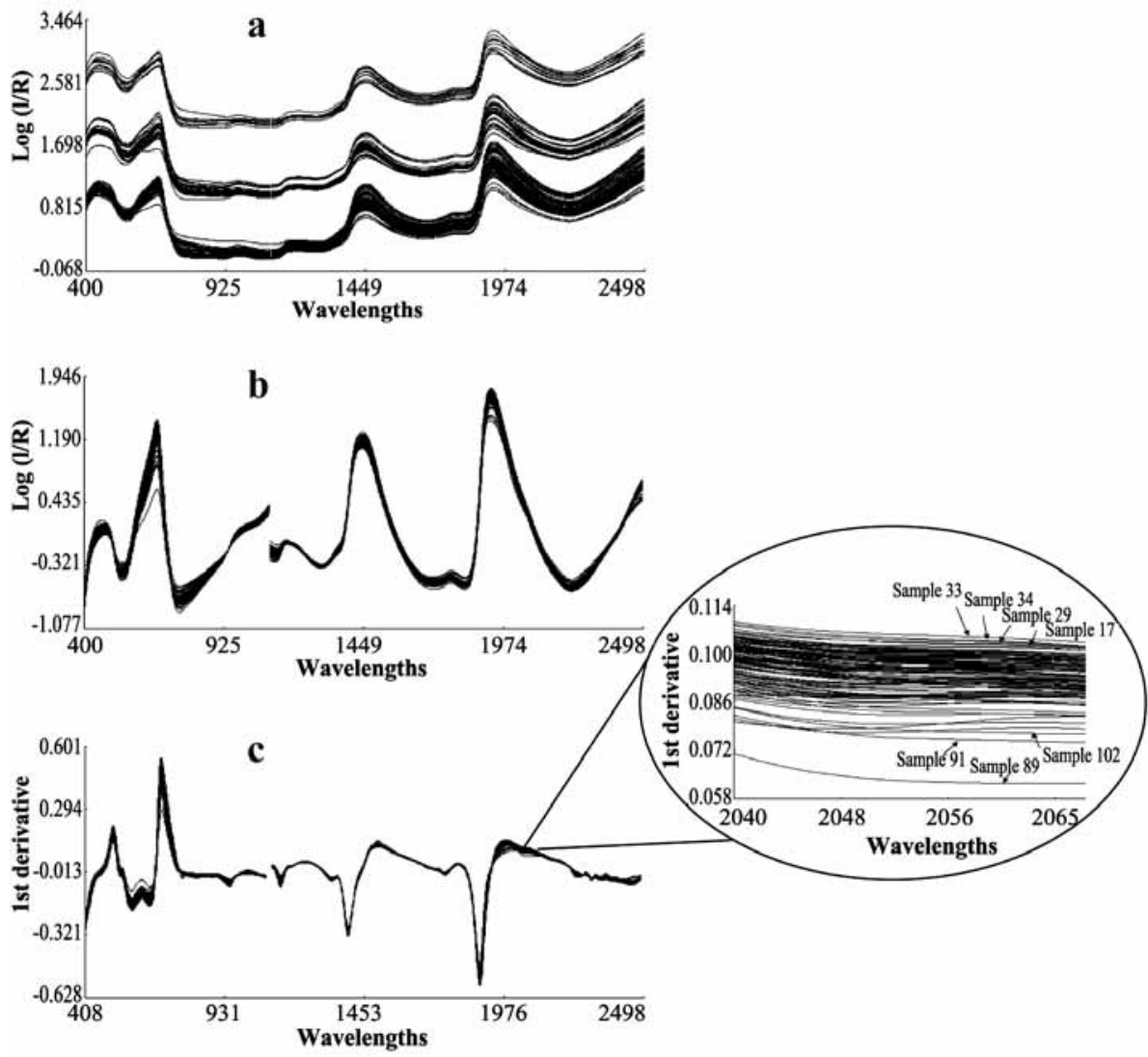

Figure 1. Reflectance spectra of fresh forage from pastures, showing original values (a) or transformed (b) by the scatter correction treatments as standard normal variance (SNV) and Detrend, or the same treatments plus a first derivative (c). Insert depicts a particular segment of the spectra where differences appear among samples of extreme protein content. 
Table 2. Statistics of best calibrations with spectra obtained by reflectance or interactance-reflectance.

\begin{tabular}{|c|c|c|c|c|c|c|}
\hline Fraction & Math treatment* & $\mathbf{R}_{\mathrm{cv}}^{2}$ & SECV & SD SECV $^{-1}$ & SECV Average & Other \\
\hline \multicolumn{7}{|c|}{ Reflectance } \\
\hline $\mathrm{DM}$ & 2,5,5,1 SNV+Detrend & 0.98 & 7.50 & 7.15 & 0.041 & \\
\hline $\mathrm{CP}$ & $1,5,5,1 \mathrm{SNV}+$ Detrend & 0.93 & 16.76 & 3.69 & 0.082 & \\
\hline ME & 2,8,8,1 SNV+Detrend & 0.80 & 0.354 & 2.23 & 0.032 & \\
\hline $\mathrm{NDF}$ & 2,5,5,1 SNV+Detrend & 0.80 & 33.58 & 2.22 & 0.075 & \\
\hline $\mathrm{ADF}$ & 2,10,10,1 None & 0.90 & 13.96 & 3.20 & 0.054 & \\
\hline SP & 1,10,10,1 SNV+Detrend & 0.85 & 14.44 & 2.63 & 0.160 & \\
\hline NDIN & 2,5,5,1 None & 0.61 & 1.89 & 1.59 & 0.260 & \\
\hline \multicolumn{7}{|c|}{ Interactance reflectance (optic fiber) } \\
\hline $\mathrm{DM}$ & 0,0,3,1 None & 0.84 & 21.29 & 2.51 & 0.120 & $3 \mathrm{~mm}$ path \\
\hline $\mathrm{CP}$ & $0,0,2,1 \mathrm{SNV}+$ Detrend & 0.75 & 32.24 & 2.00 & 0.160 & $1 \mathrm{~mm}$ path \\
\hline ME & $0,0,4,1$ None & 0.63 & 0.47 & 1.65 & 0.042 & $5 \mathrm{~mm}$ path \\
\hline NDF & $1,4,4,1$ None & 0.63 & 43.87 & 1.65 & 0.097 & $3 \mathrm{~mm}$ path \\
\hline $\mathrm{ADF}$ & $0,0,5,1$ None & 0.66 & 25.53 & 1.71 & 0.096 & $3 \mathrm{~mm}$ path \\
\hline SP & $0,0,4,1$ None & 0.77 & 18.81 & 2.11 & 0.200 & $1 \mathrm{~mm}$ path \\
\hline NDIN & $0,0,5,1$ None & 0.66 & 1.76 & 1.71 & 0.240 & $1 \mathrm{~mm}$ path \\
\hline
\end{tabular}

DM: dry matter. CP: crude protein. ME: Metabolizable energy. NDF: neutral detergent fiber. ADF: acid detergent fiber. SP: soluble protein. NDIN: neutral detergent insoluble nitrogen. $\mathrm{R}^{2} \mathrm{cv}$ : Coefficient of determination of cross validation. SECV: standard error of cross validation. SD SECV ${ }^{-1}$ : ratio of standard deviation of reference data (calibration set) to standard error of cross validation, ratio of standard error of cross validation to average of reference data (see text for details).

* Math treatment: Derivative order (first number), subtraction gap in data points (second number), first smooth segment in data points (third number) and segment for a second smooth segment in data points (fourth number). SNV: standard normal variate (see text for details).
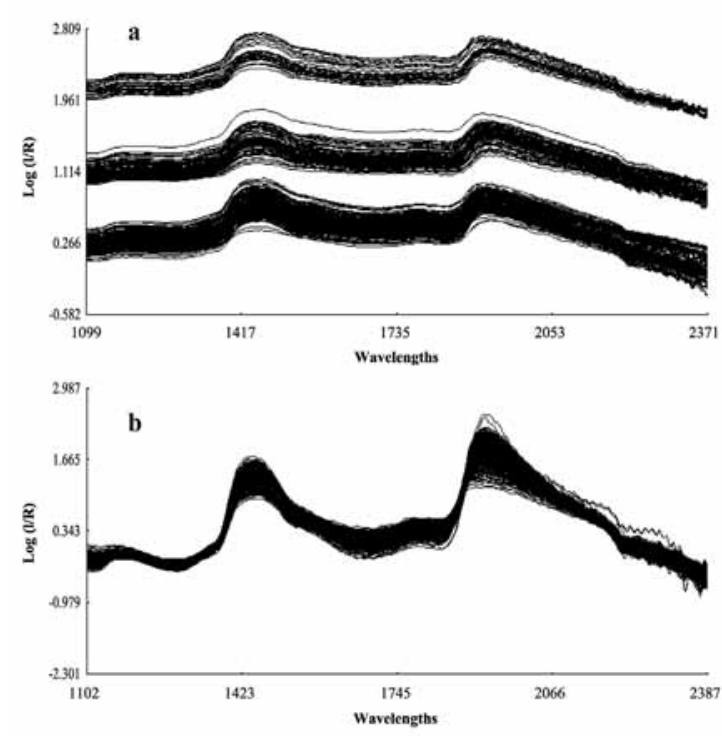

Figure 2. Interactance-reflectance (optic fiber with light path of $3 \mathrm{~mm}$ ) "raw" spectra of fresh forage from pastures, showing band shifts explained by changes in the equipment (a) and after applying a scatter correction treatment as standard normal variance (SNV), plus Detrend and a first smoothing of five data points (b).
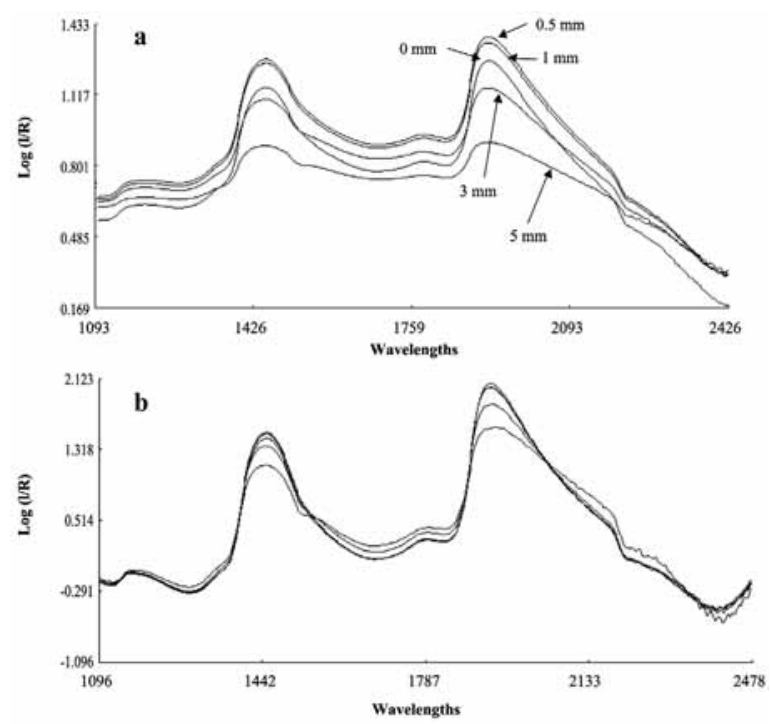

Figure 3. Mean interactance-reflectance (optic fiber) "raw" spectra of fresh forage from pastures. 3a) each curve represents mean spectra for all samples scanned with a given light aperture or pathlength from 0 to $5 \mathrm{~mm}$ (arrows); 3b) depicts the same curves, after applying scatter correction treatments as standard normal variance (SNV), and Detrend and a math treatment of smoothing segments of five data points. 

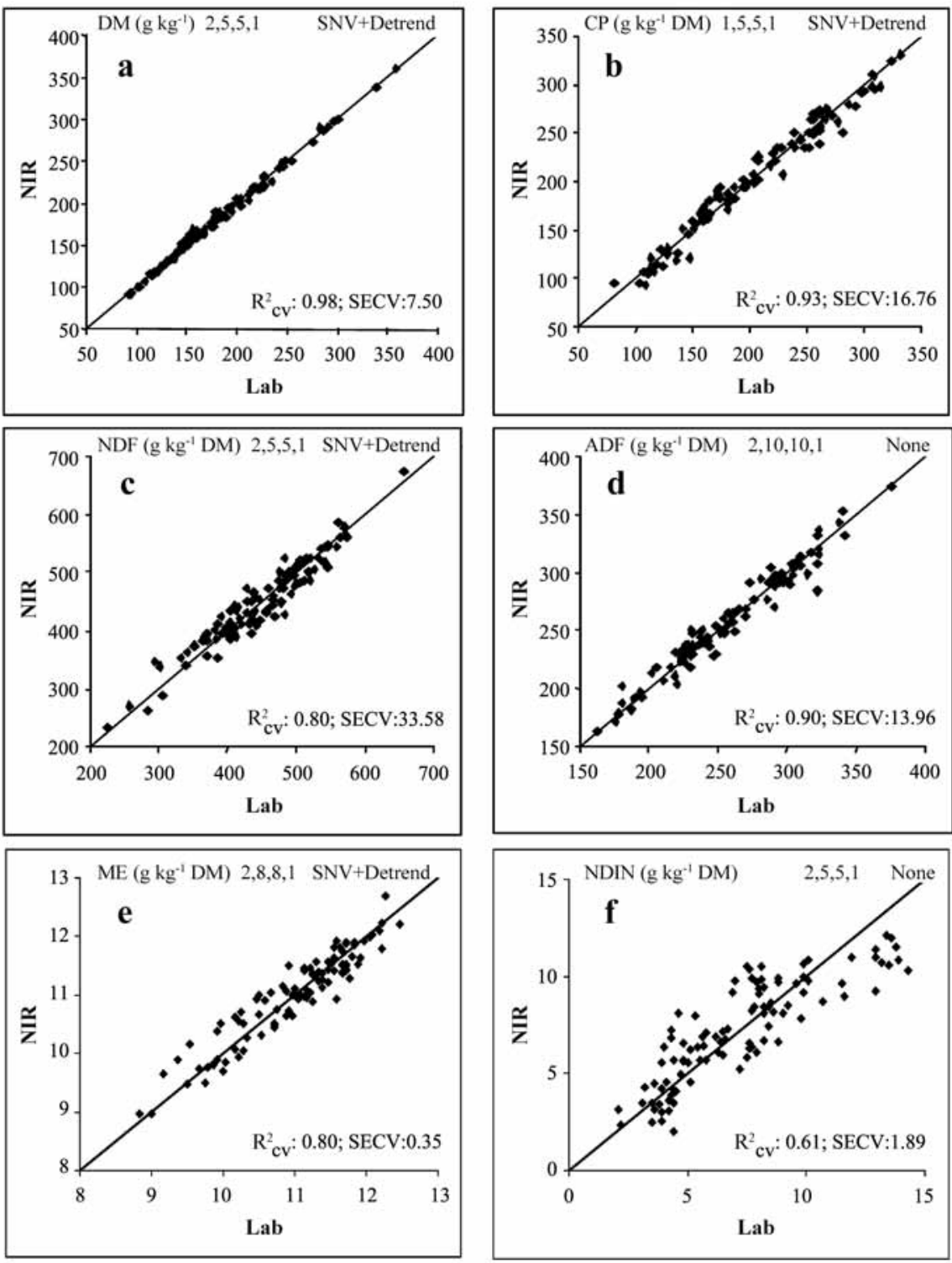

Figure 4. Near infrared reflectance (NIR) predicted versus reference (lab) data for different fractions of fresh forage from pastures. Each graph represents the best calibration obtained for DM: dry matter (a); CP: crude protein (b); NDF: neutral detergent fiber (c); ADF: acid detergent fiber (d); ME: metabolizable energy (e) and NDIN: insoluble nitrogen in neutral detergent (f).

considered as dependable because the error represented an important proportion of the variability of data. This was also the case for the equations for NDF.

The relation between NIR prediction and composition obtained by reference methods was presented for the analysed fractions (Figures 4 and 5). For each fraction, a math treatment was included. For instance, for DM (Figure 4a) a 2,5,5,1 was applied to obtain the best equation, meaning that a second derivative or subtraction over five data points, a first smoothing over a segment of five data points and a second smoothingt over one data point, plus SNV and Detrend, were employed.

It was confirmed that the best equations were those for $\mathrm{DM}, \mathrm{CP}$ and $\mathrm{ADF}$, in the reflectance mode, as their respective scatter plots depict data points closer to the diagonal equal response line. Although according to these results, NDF and the estimated ME values cannot be confidently predicted by NIRS, a strong relationship can nonetheless be seen in the configuration of the data. This reinforces the idea that spectra can recover signals from chemical bonds that in some way are related to empirical entities, such as those mentioned above. 

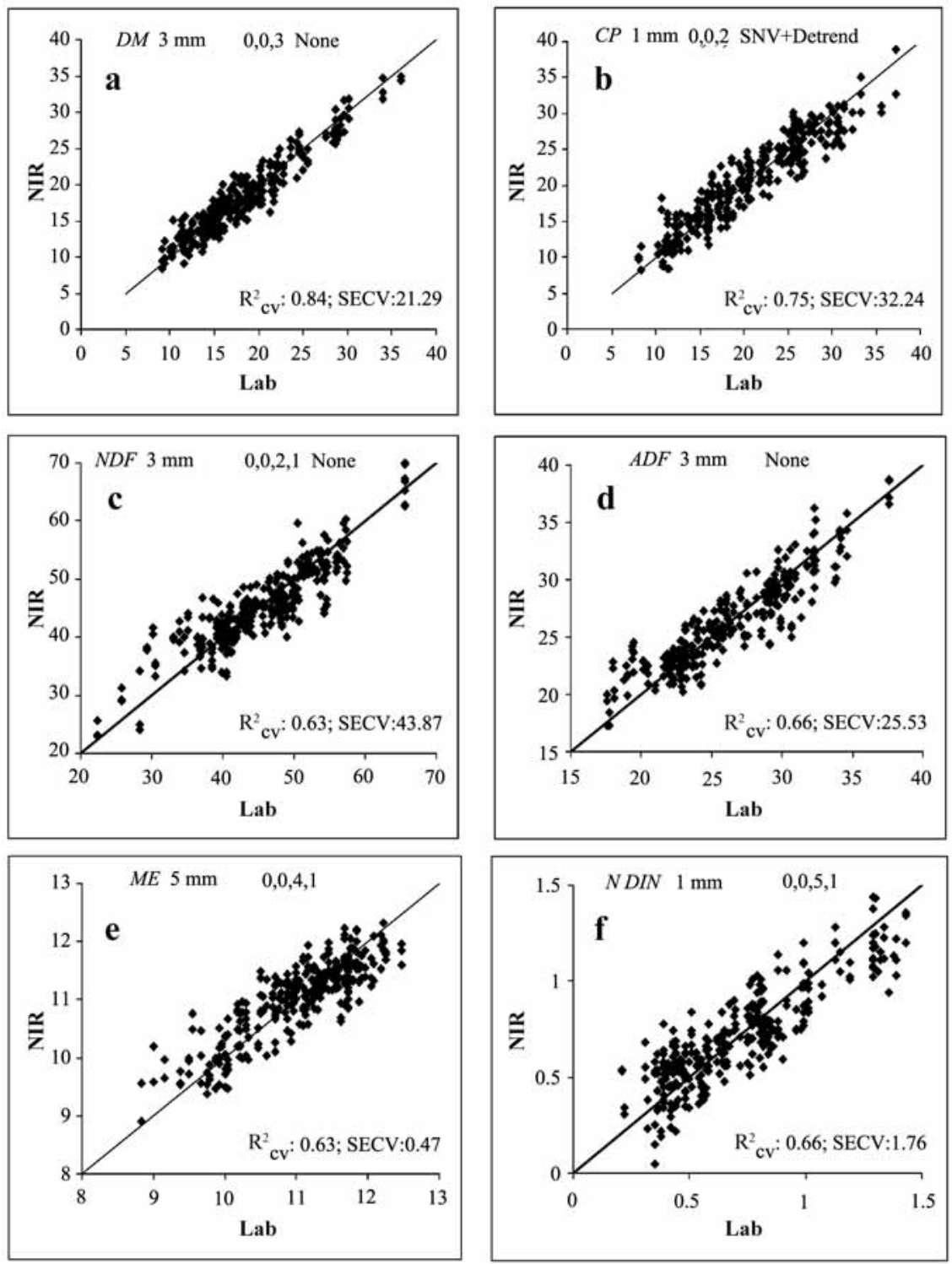

Figure 5. Near infrared reflectance (NIR) (interactance-reflectance) predicted versus reference (lab) data for different fractions of fresh forage from pastures. Each graph represents the best calibration obtained across different math treatments and light paths, for DM: dry matter (a); CP: crude protein (b); NDF: neutral detergent fiber (c); ADF: acid detergent fiber (d); ME: metabolizable energy (e) and NDIN: insoluble nitrogen in neutral detergent (f).

In line with the data presented in Table 2, which shows better results for samples scanned in reflectance, NIR predicted values (Figure 4) are closer to the equal response line (Figure 5). Although a relationship between NIR and reference data can also be distinguished using equations developed from spectra taken with fiber optics technology, the results are far from acceptable for prediction purposes. A probable explanation for these poor results could be in the surface scanned with the optic fiber probe used in this work, which is much smaller than the area covered by the forage cell employed by the transport module for the reflectance spectra. Subsequent work could be oriented to establishing if a larger number of readings per sample could improve the predictive ability of interactance reflectance technology.

The usefulness of a NIR prediction depends, on the one hand, on the accuracy of the results with respect to reference data, and on the other, on the level of error we are prepared to accept and how fast we can have the results available to make important management decisions. In the case of pasture management, the change in ME and DM content could be important features in deciding when to harvest for forage conservation, or the removal of animal stock from a given paddock. 


\section{CONCLUSION}

The results obtained in this work demonstrate that several compositional fractions of forage from different types of swards can be accurately predicted by NIRS on fresh plant material, working in reflectance with a suitable forage cell. Fiber optics technology, on the other hand, shows some potential, but results are not acceptable so far.

\section{ACKNOWLEDGEMENTS}

This work was supported by a grant from the Chilean National Fund for Science and Technology (FONDECYT), project 1000432.

\section{RESUMEN}

Predicción de la composición de pradera fresca mediante espectroscopía de reflectancia o interactanciareflectancia en el infrarrojo cercano. Disponer de técnicas bromatológicas rápidas y precisas ayudaría a optimizar decisiones en el manejo de praderas. En este trabajo se evaluó el potencial de una de tales técnicas, la espectroscopía de reflectancia en el infrarrojo cercano (NIRS) para predecir el valor nutricional de praderas al estado fresco y comparar dos formas de colectar los espectros: reflectancia e interactancia-reflectancia (fibra óptica). Se colectaron 107 muestras de praderas en las regiones templado-húmedas del sur de Chile (Los Ríos y Los Lagos). Luego de tomar sus espectros, se analizaron por métodos de referencia para materia seca(DM), proteína bruta (CP), energía metabolizable (ME), fibra detergente neutro (NDF) y ácido (ADF), carbohidratos solubles (SC), proteína bruta soluble (SCP) y $\mathrm{N}$ insoluble en detergente neutro (NDFIN). Se desarrollaron calibraciones y se eligieron como mejores ecuaciones aquellas que en una validación cruzada, mostraron un mayor coeficiente de determinación $\left(\mathrm{R}^{2} \mathrm{CV}\right)$ y un menor error estándar $\left(\mathrm{SE}_{\mathrm{CV}}\right)$. Los mejores resultados se lograron en reflectancia para DM y CP, con $\mathrm{R}^{2}{ }_{\mathrm{CV}}$ de 0,99 y 0,91, respectivamente, $\mathrm{y}$ $\mathrm{SE}_{\mathrm{CV}}$ de 6,5 y 18,4 $\mathrm{g} \mathrm{kg}^{-1}$, respectivamente. Luego se ubicaron las ecuaciones para ADF, SCP y ME, con valores $\mathrm{R}^{2}{ }_{\mathrm{CV}}$ de 0,$87 ; 0,84$ y 0,82 y $\mathrm{SE}_{\mathrm{CV}}$ de $15,88 \mathrm{~g} \mathrm{~kg}^{-1}, 15,45 \mathrm{~g}$ $\mathrm{kg}^{-1}$ y 0,34 $\mathrm{Mj} \mathrm{kg}^{-1}$, respectivamente. Las ecuaciones para NDF, SC y NDFIN, con $\mathrm{R}^{2} \mathrm{CV}$ de 0,$78 ; 0,77$ y 0,61 y $\mathrm{SE}_{\mathrm{CV}}$ de 35,$57 ; 94,54$ y $1,89 \mathrm{~g} \mathrm{~kg}^{-1}$, respectivamente; resultaron poco confiables para efectos de predicción. La técnica de interactancia-reflectancia produjo resultados inferiores para todas las fracciones.

Palabras clave: composición de praderas, predicción NIRS, espectroscopía de reflectancia en infrarrojo cercano, praderas frescas, fibra óptica.
Alomar, D., R. Fuchslocher, and M. De Pablo. 2003. Effect of preparation method on composition and NIR spectra of forage samples. Anim. Feed Sci. Technol. 107:191-200.

Alomar, D., R. Fuchslocher, and S. Stockebrand. 1999. Effects of oven- or freeze-drying on chemical composition and NIR spectra of pasture silage. Anim. Feed Sci. Technol. 80:309-319.

AOAC. 1996. Official methods of analysis of the Association of Official Analytical Chemists (AOAC). $16^{\text {th }}$ ed. AOAC International, Gaithersburg, Maryland, USA.

Deaville, E.R., and P.C. Flinn. 2000. Near-infrared (NIR) spectroscopy: an alternative approach for the estimation of forage quality and voluntary intake. p. 301-320. In Givens, D.I., E. Owen, R.F.E. Axford, and H.M Omed (eds.) Forage evaluation in ruminant nutrition. CABI Publishing, Wallingford, UK.

Deinum, B., and A. Maassen. 1994. Effects of drying temperature on chemical composition and in vitro digestibility of forages. Anim. Feed Sci. Technol. 46:75-86.

Garrido, O., and E.A. Mann. 1981. Composición química, digestibilidad y valor energético de una pradera permanente de pastoreo a través del año. 61 p. Tesis Ingeniero Agrónomo, Universidad Austral de Chile, Valdivia, Chile.

ISI. 1999. Infrasoft International, LLC (ISI) Windows Near Infrared Software, WinISI II, Version 1.02A. p. 192. Foss NIRSystems, Silver Spring, Maryland, USA.

Kennedy, C.A., J.A. Shelford, and P.C. Williams. 1996. Near infrared spectroscopic analysis of intact grass silage and fresh grass for dry matter, crude protein and acid detergent fiber. p. 524-530. In Davies, A.M.C., and P. Williams (eds.) Near infrared spectroscopy: the future waves. NIR Publications, Chichester, UK.

Licitra, G., T.M. Hernández, and P.J. Van Soest. 1996. Standardization of procedures for nitrogen fractionation of ruminant feeds. Anim. Feed Sci. Technol. 57:347-358.

Miller, C.E. 2001. Chemical principles of near infrared technology. p. 19-37. In Williams P., and K. Norris (eds.) Near-Infrared technology in the agricultural and food industries. American Association of Cereal Chemists (AACC), St. Paul, Minnesota, USA.

Osborne, B.G., T. Fearn, and P.H. Hindle. 1993. Practical NIR spectroscopy with applications in food and beverage analysis. Longman Scientific and Technical, Harlow, Essex, UK. 
Reeves, J.B. III. 2000. Use of near infrared reflectance spectroscopy. p. 185- 207. In J.P.F. D’Mello (ed.) Farm animal metabolism and nutrition. CABI Publishing, Wallingford, UK.

Tilley, J., and R. Terry. 1963. A two stage technique for the in vitro digestion of forage crops. J. Br. Grassl. Soc. 18:104-111.
Van Soest, J.P., J.B. Robertson, and B.A. Lewis. 1991. Methods for dietary fiber, neutral detergent fiber and non-starch polysaccharides in relation to animal nutrition. J. Dairy Sci. 74:3583-3597.

Williams, P.C. 2001 Implementation of near-infrared technology. p. 145-169. In Williams, P., and K. Norris (eds.) Near-Infrared technology in the agricultural and food industries. American Association of Cereal Chemists (AACC), St. Paul, Minnesota, USA. 


\title{
MODELLING SUPPLEMENTATION STRATEGIES FOR BEEF STEER REARING AND FATTENING SYSTEMS IN SOUTHERN CHILE
}

\author{
Paula Toro $^{1 *}$, Adrián Catrileo², Claudio Aguilar ${ }^{1}$, and Raúl Vera ${ }^{1}$
}

\begin{abstract}
A mathematical model was developed to analyze beef production systems in Southern Chile. The study considered the identification of the main components of systems under different beef steer management strategies, using pasture with or without supplementation and back grounding cattle on pasture followed by a winter period of confined feeding with pasture silage and concentrates. Validation of model outputs using $200 \mathrm{~kg} \mathrm{LW}$ Hereford steers against real experimental data showed no significant differences $(P \geq 0.01)$ between simulated and observed final weights. In order to analyze the interaction between the stocking rate (SR) and supplementation, three SR of 2, 2.5 and 3 steers $\mathrm{ha}^{-1}$ with and without pasture silage supplementation at the rate of $5 \mathrm{~kg} \mathrm{DMd}^{-1}$ steer $^{-1}$ for the length of the entire period were simulated. Means were compared by the least significant difference (LSD, P $\leq 0.05$ ). Significant differences were found in terms of final weights, which decreased with increasing SR regardless of the supplementation level, although silage supplementation tended to reduce differences between SR. A second set of simulation runs was carried out to simulate on-farm finishing of the steers through a final phase of confined feeding based on a ration of silage and concentrates. Final weights differed between SR and systems and results showed that the optimum corresponded to 2.5 steers $\mathrm{ha}^{-1}$, since at this SR the largest income corresponded to the smallest mean cost. It is concluded that a stocking rate of 2.5 steers ha $^{-1}$ is feasible if winter supplementation is available, independently of a finishing period in feedlot.
\end{abstract}

Key words: beef cattle, supplementation, grazing systems, simulation models.

\section{INTRODUCTION}

Beef production systems in Southern Chile ( $38^{\circ} 41^{\prime} \mathrm{S}$, $72^{\circ} 25^{\prime} \mathrm{W}, 200$ m.a.s.l. and $1300 \mathrm{~mm}$ rainfall) are based on dual purpose (beef and milk) cattle. The predominant breed is Overo Colorado, crossed with Hereford and occasionally other beef breeds. Traditionally, dual purpose breeds account for nearly $80 \%$ of the total cattle population (Catrileo and Goic, 2005). According to official statistics, nearly $50 \%$ of the total dairy and beef cattle population is owned by peasant farmers (ODEPA, 2001) that run predominantly cow-calf systems with low levels of productivity and efficiency. The overall stocking density is 0.5 cattle units ha ${ }^{-1}$ devoted to livestock, on farms of less than 50 ha where the main forage resources are naturalized pastures and hay supplementation in

'Pontificia Universidad Católica de Chile, Facultad de Agronomía e Ingeniería Forestal, Av. Vicuña Mackenna 4860, Santiago, Chile. *Corresponding author (pmtoro@uc.cl).

Instituto de Investigaciones Agropecuarias, Centro Regional de Investigaciones Carillanca, Casilla 58-D, Temuco, Chile.

Received: 28 March 2008.

Accepted: 27 May 2008. winter (Catrileo and Klee, 2005). Naturalized pastures are generally old perennial ryegrass (Lolium perenne L.) white clover (Trifolium repens L.) grasslands that are degraded to various extents over time and are mixed with a variety of volunteer grasses. Pasture growth is markedly seasonal, with $60 \%$ of the total pasture yield concentrated in spring, with a small second peak in the fall.

Animal are reared, backgrounded and fattened on year-round grazed pastures. Pasture-fed finished steers can be produced if sown, well managed pastures are available, but most calves produced by small farmers are sold for backgrounding and finishing to medium and large farms that have better resources, such as sown pastures and cereal crops, and which are therefore able to finish cattle for the internal and export market. This group is the focus of the current paper.

Regardless of the situation, there is general agreement that well managed perennial ryegrass and white clover pastures are consistent with animal well being and preservation of natural resources and provide cheap feed.

Independently of size, farmers generally use rotational grazing and supplement pasture hay or silage to 
grazing animals during the low forage availability winter period. Under these conditions, conserved forages are a relatively expensive feed, and the interaction between conservation, supplementation and the on-farm stocking rate is hypothesized to have an important influence on the economic outcome of the production system.

The favourable climatic and sanitary conditions of Southern Chile, including the fact that the country is free of foot-and-mouth disease, and the relatively free access of Chile to the major beef importing countries, constitute an important incentive for the intensification of beef production. Nevertheless, weak within-country production chains and links, and the fact that most beef farms are relatively small, conspire against the expedient incorporation of new technologies and a sustained process of intensification.

The many possible combinations of variables, such as farm size, initial weight and age of animals, initial grazing date, grazing management and feed quality are associated with the economic outcome of the system. Nevertheless very few technological options have been experimentally tested, and therefore the present study used simulation to analyze the effect of changes in critical farmercontrolled system variables on the likely physical and economic performance of medium-size farms, and assess the probable impact of introducing new technological options.

The objective of the model was to evaluate the productive and economic response of the animals through different scenarios feasible to find in rearing-finishing beef systems in order to improve the income of the system.

\section{MATERIALS AND METHODS}

To develop the simulation model it was necessary to identify the main system components, subsystems and relevant variables and write the computer code, as briefly described below.

\section{Model development}

The development of the model followed the system analysis methodology advanced and used by several authors (Hoover and Perry, 1989; Aguilar et al., 2003). The model and databases were adapted to simulate performance of beef cattle grazing temperate pastures in Southern Chile. The model was programmed in Visual Basic NET (Halvorson, 2003).

The model used input and output variables (Aguilar, 1997). Input variables included: number and weight of steers; type, quantity and nutritive value of pasture and its size, quantity and nutritive value of supplement, as well as the timing of supplementation; market conditions, labor and salaries, available infrastructure and its cost. Output variables were: dry matter (DM) intake, stocking rate, final live weight (LW), LW gain; and average and marginal costs.

State variables included: digestibility of available DM; diet selection represented through a selection index, corrected for availability and digestibility; potential DM intake, crude protein (CP) and metabolizable energy (ME); $\mathrm{CP}$ and $\mathrm{ME}$ concentration of the consumed diet; energy costs of grazing and maintenance, the final energy balance that results in LW gain or loss. Daily feeding costs, including that of the pasture and eventual supplement, are computed, as well as related labor costs, financial costs due to animals, and the proportional costs due to infrastructure and taxes.

The model comprises four main modules: animals, pasture, management and market conditions. The animal component considers forage intake, nutritional requirements for maintenance, LW gain and grazing, and the energy balance that allows normal animal performance according to physiological conditions. The pasture component uses empirical growth curves determined for pastures and forages commonly used in the region. The respective module reads the average monthly potential pasture DM growth and its digestibility, and these initial values are modified according to the state of the system. The management module allows for rotational grazing, the optional use of supplements, and also represents the use of infrastructure and labor characteristic of the region. Market conditions include estimates of fixed costs like labor, infrastructure and equipment maintenance, and variable costs, such as feed and animal health.

\section{Biological components}

Animals. The endpoint of the finishing process is essentially conditioned by the animal's weight, but the age at slaughter influences meat quality and needs to be considered as well. Therefore, both variables determine the sale of the animals during simulation runs, and the user can specify age and/or minimum sale weight.

Estimation of the requirements for $\mathrm{ME}$ and $\mathrm{CP}$ were based on equations proposed by the Agricultural and Food Research Council (AFRC, 1993) and the Commonwealth Scientific and Industrial Research Organization (CSIRO, 1990). The amount of these nutrients consumed is based on the intake of forage and/or supplement, as advanced by Aguilar et al. (2003) and CSIRO (1990), whereas the interaction between forage consumption and concentrate intake was based on Aguilar (1997). Voluntary pasture intake and cattle mortality were treated as stochastic variables with user-specified mean and standard deviation. 
The model estimates daily intake of forage and supplement under grazing conditions. Initially, a potential DM intake (PDMI) is calculated reflecting the characteristics of the animal under non-limiting conditions. To this end, the model uses a reference animal weight, the current weight of the animal, and its relationship to mature weight (CSIRO, 1990). An algorithm (Aguilar et al., 2003) that computes substitution, supplementary, or additive effects between pasture and supplement intake is used to correct voluntary forage DM intake (VFDMI). The latter is further corrected by a digestibility factor (FCG) and an availability factor (FCD) as follows:

$$
\mathrm{VFDMI}=\mathrm{PDMI} \times \mathrm{FCG} \times \mathrm{FCD}
$$

where FCG is estimated based on the forage availability, and FCD is calculated from a linear equation adjusted for digestibility values between 40 and $80 \%$. The DM digestibility of diet is estimated from a selection index that corrects the average digestibility of offered forage (Aguilar et al., 2003).

Pastures. Monthly potential growth rates of the pastures, and their variation in digestibility and $\mathrm{CP}$, were used as an input to quantify the potential pasture's DM and nutrient availability. Forage digestibility was corrected for selective grazing, which in turn depended upon forage availability and stocking rate, as discussed by Aguilar et al. (2006). For finishing the animals, the silage requirement was simulated in the model assuming ad libitum intake and typical nutritive values observed at the farm level.

\section{Economic analyses}

Quantification of the economic performance of alternative systems is essential for comparing production alternatives. The simulation model therefore considers fixed and variable costs of production. Fixed costs include labor, infrastructure and machinery maintenance, and general administrative costs. Variable costs are those related to feeding and animal health. The opportunity cost of land was considered as a third component, quantified as the cost of producing forage, and that of animals. Thus, the user has access to two economic analyses, a total and an operational cost, depending upon the inclusion of opportunity costs or not.

\section{Statistical analysis}

Initial and final conditions for the experimental and simulated results were compared and the final weights were compared to validate the model using a $\mathrm{z}$ test, assuming homogeneity of variances and with a sample size of 40 animals.
In order to analyze the interaction of the stocking rate and supplementation, three stocking rates were simulated with and without grass silage supplementation at the same rate. Each scenario was replicated 20 times. Means of the output variables were compared by the least significant difference (LSD, $\mathrm{P} \leq 0.05)$.

\section{RESULTS AND DISCUSSION}

\section{Model verification}

Adequately documented experimental results useful for a thorough validation of model outputs are very scarce. Rojas and Romero (1994) carried out a grazing experiment replicated in each of five consecutive years, in the Central Valley of La Araucanía Region, Chile, using 7-8 mo of age, $200 \mathrm{~kg} \mathrm{LW}$, weaned Hereford steers introduced to the experimental pastures on April of each year and fattened until December, using an intensive system of rotational grazing. Simulation runs were carried out for a similar length of time as the experiment, and with the same amount of silage supplementation. No significant differences $(\mathrm{P} \geq$ 0.01 ) were found between simulated and observed final weights. Similarly, there were no significant differences $(\mathrm{P} \geq 0.05)$ in the amount of silage produced in each of the 5 years (Table 1$)$.

\section{Experimentation}

To study changes in economic and physical performance of the system in response to management practices, a number of scenarios, including changes in the stocking rate, levels of supplementation during the winter period, and a final fattening period in feedlot, were simulated for a 300 ha farm of the region.

\section{Stocking rate and supplementation}

The simulated system assumes that $240 \mathrm{~kg}$ Overo Colorado x Hereford calves are bought in April and are sold at $2 \mathrm{yr}$ of age or when they attain $450 \mathrm{~kg} \mathrm{LW}$, whichever occurs first. Animals grazed during the fall and winter period, from May to September, supplemented with pasture silage. The purchase price was $\$ 610 \mathrm{~kg}^{-1}$ (1 $\mathrm{US} \$=\$ 540$ ), and the sale price is $\$ 580 \mathrm{~kg}^{-1}$ (Tattersall, 2006). Three stocking rates, $2,2.5$ and 3 head ha ${ }^{-1}$, were simulated with and without grass silage supplementation at the rate of $5 \mathrm{~kg} \mathrm{DM} \mathrm{d}^{-1}$ head $^{-1}$.

Each scenario was replicated 20 times. The output variables of interest included final weight and age of steers, mean total and operational cost per $\mathrm{kg}$ LW, the financial income and the operational income of the farm. Means were compared by the least significant difference (LSD, $\mathrm{P} \leq$ 0.05) (Table 2). In all cases, simulation runs were terminated upon reaching the maximum stipulated 
Table 1. Input-output data and observed and simulated output data for five consecutive years of fattening on pasture, pasture silage conservation and supplementation. Input data and initial conditions are as reported by Rojas and Romero (1994). Simulated results are means of 20 replicates \pm SD.

\begin{tabular}{lccrrr}
\hline Variables & Year 1 & Year 2 & Year 3 & Year 4 & Year 5 \\
\hline Stocking rate, steers ha ${ }^{-1}$ & 2.5 & 3.0 & 3.5 & 4.0 & 5.0 \\
Area conserved, \% & 26.2 & 14.1 & 12.0 & 3.9 & 0 \\
Initial date (day/month) & $09 / 04$ & $15 / 04$ & $14 / 04$ & $05 / 04$ & $05 / 04$ \\
Ending date (day/month) & $10 / 12$ & $14 / 01$ & $05 / 01$ & $23 / 12$ & $18 / 01$ \\
Grazing period, days & 255 & 274 & 266 & 270 & 288 \\
Days of supplementation & - & - & 31 & 75 & 92 \\
Initial live weight, kg steer ${ }^{-1}$ & 194 & 210 & 205 & 206 & 189 \\
\hline & \multicolumn{7}{c}{ Observed } & 388 & 390 & 386 & 342 \\
Final live weight, kg steer ${ }^{-1}$ & 378 & 4668 & 4397 & 1333 & - \\
Pasture conserved DM, kg & 8160 & Simulated & & & \\
Final live weight, kg steer ${ }^{-1}$ & $374.3 \pm 8.91$ & $390.8 \pm 7.34$ & $390.6 \pm 5.51$ & $387.4 \pm 5.93$ & $341.4 \pm 9.75$ \\
Pasture conserved DM, kg & $8463 \pm 943$ & $4790 \pm 625$ & $4392 \pm 998$ & $1351 \pm 52$ & - \\
\hline
\end{tabular}

DM: dry matter.

Table 2. Simulated final live weights and financial performance in response to changes in stocking rate and pasture silage supplementation.

\begin{tabular}{|c|c|c|c|c|c|c|c|}
\hline $\begin{array}{l}\text { Stocking rate } \\
\left(\text { steers ha }^{-1}\right)\end{array}$ & $\begin{array}{c}\text { Suplemen- } \\
\text { tation } \\
\text { (yes/no) }\end{array}$ & $\begin{array}{c}\text { Final weight } \\
\text { (kg) }\end{array}$ & $\begin{array}{l}\text { Mean total } \\
\text { cost }\end{array}$ & $\begin{array}{c}\text { Mean } \\
\text { operational } \\
\text { cost }\end{array}$ & $\begin{array}{l}\text { Total } \\
\text { income }\end{array}$ & $\begin{array}{c}\text { Operational } \\
\text { income }\end{array}$ & Sales \\
\hline \multirow{3}{*}{2.0} & & $\mathrm{~kg}$ & $-\$ \mathrm{Ch}$ & $\mathrm{kg}^{-1}$ & $\longrightarrow$ millio & $\mathrm{n} \$ \mathrm{Ch}$ & $000^{\prime} \mathrm{kg}$ \\
\hline & No & $450.3 \pm 6.6 c$ & $473.6 \pm 5.5 \mathrm{a}$ & $386.2 \pm 5.5 \mathrm{a}$ & $23.3 \pm 1.8 \mathrm{c}$ & $46.7 \pm 2.1 b c$ & $270.1 \pm 3.9 \mathrm{a}$ \\
\hline & Yes & $495.6 \pm 3.6 f$ & $469.9 \pm 3.0 \mathrm{a}$ & $397.2 \pm 2.9 b$ & $26.7 \pm 1.1 \mathrm{~d}$ & $48.4 \pm 1.2 \mathrm{c}$ & $297.3 \pm 2.2 \mathrm{c}$ \\
\hline \multirow[t]{2}{*}{2.5} & No & $418.3 \pm 4.2 b$ & $501.3 \pm 4.5 \mathrm{c}$ & $414.3 \pm 4.3 \mathrm{c}$ & $18.4 \pm 2.5 b$ & $45.7 \pm 1.8 b$ & $313.7 \pm 3.2 \mathrm{~d}$ \\
\hline & Yes & $493.5 \pm 3.6 \mathrm{e}$ & $470.6 \pm 2.7 \mathrm{a}$ & $397.6 \pm 3.1 \mathrm{~b}$ & $33.1 \pm 1.2 \mathrm{e}$ & $60.1 \pm 1.6 \mathrm{~d}$ & $370.1 \pm 2.8 \mathrm{e}$ \\
\hline \multirow[t]{2}{*}{3.0} & No & $307.7 \pm 13.2 \mathrm{a}$ & $653.2 \pm 25.1 d$ & $562.7 \pm 23.7 \mathrm{~d}$ & $-25.5 \pm 5.9 \mathrm{a}$ & $-0.5 \pm 6.6 \mathrm{a}$ & $276.9 \pm 11.8 b$ \\
\hline & Yes & $466.9 \pm 7 d$ & $492.6 \pm 6.7 b$ & $419.6 \pm 6.4 c$ & $28.7 \pm 3.2 \mathrm{~d}$ & $59.0 \pm 3.5 \mathrm{~d}$ & $420.2 \pm 6.3 f$ \\
\hline
\end{tabular}

Vertical means with different letter differ significantly $(\mathrm{P} \leq 0.01)$.

age of sale of $301 \mathrm{~d}$. On the other hand, significant differences were found in terms of final weights, which decreased with increasing stocking rate regardless of supplementation level, although silage supplementation tended to reduce differences between stocking rates. All associated costs increased with increasing stocking rates due to falling final weights (Figure 1). These results are in accordance with what was reported by Rojas et al. (2004), who used similar stocking rates at 2.5 steers $\mathrm{ha}^{-1}$, but in the experiment LW gain per hectare was higher, probably due to the use of a higher amount of supplement.
Unsupplemented LW production per hectare increased initially but then fell at the highest stocking rate due to limited forage availability. When silage was provided, production per hectare increased (Table 3) although at a decreasing rate at the highest stocking rate, again due to low forage availability during the non-supplemental period.

Total and operational income initially increased with stocking rate in all simulated systems, after which the diminishing daily weight gains did not compensate for the increase in the number of animals (Table 2). 


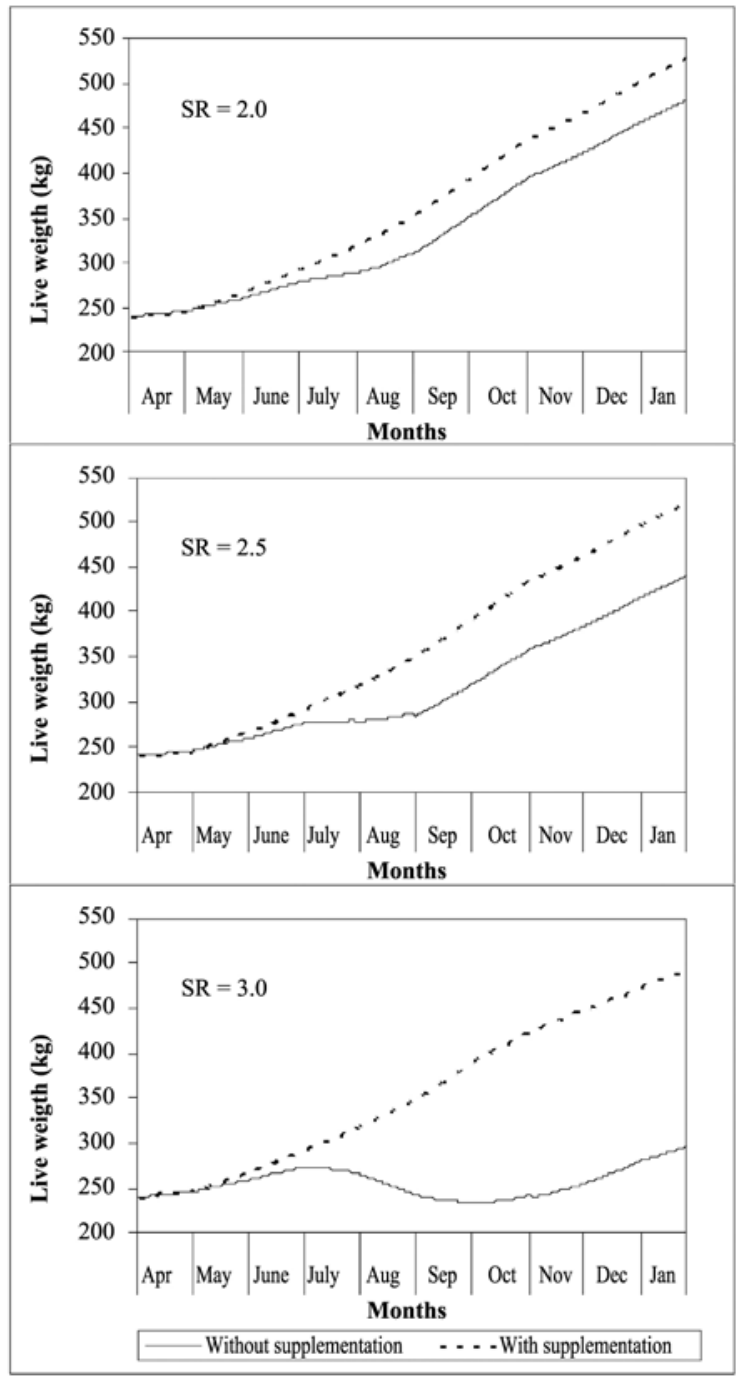

Figure 1. Simulated effects of three stocking rates (SR, steers $\mathrm{ha}^{-1}$ ) and supplementation on the evolution of the live weight of grazing steers.

Table 3. Simulated weight gain per hectare at different stocking rates, with/without pasture silage supplementation.

\begin{tabular}{cccc}
\hline Stocking rate & \multicolumn{2}{c}{ Not supplemented } & Supplemented \\
\hline steers ha ${ }^{-1}$ & & $\mathrm{~kg} \mathrm{ha}^{-1}$ & \\
\cline { 2 - 2 } 2.0 & 540 & & 631 \\
2.5 & 596 & 784 \\
3.0 & 383 & 861 \\
\hline
\end{tabular}

As expected, the inflexion point is reached first in the unsupplemented treatments, whereas supplementation partially compensated for the increased stocking rates.

\section{Stocking rate, supplementation and feedlot finishing}

A second set of simulation runs was carried out to simulate on-farm steer finishing through a final phase of confined feeding. This last phase lasted $80 \mathrm{~d}$, and was based on a ration of silage and concentrates containing 2.3 Mcal EM kg ${ }^{-1}$ DM, $14 \%$ CP and a cost of $\$ 50 \mathrm{~kg}^{-1} \mathrm{DM}$ with the objective of achieving a final weight of 480 to $540 \mathrm{~kg}$ at an age about 20 months. The remaining conditions were as described before.

Age at sale was the factor determining the length of the simulated period, which in all cases lasted $380 \mathrm{~d}$. As shown in Table 4, final weights differed between stocking rates and systems, but the differences are smaller than those reported in Table 1, due to compensatory gains realized during the feedlot period.

The calculated mean costs and total income (Table 4) show that the optimum is 2.5 steers $\mathrm{ha}^{-1}$, since this stocking rate provides the highest income at the lowest mean cost. Comparison to the previous set of simulations shows that at stocking rates of 2 and 2.5 steers ha $^{-1}$, the financial income of unsupplemented systems increases by 17 and $22 \%$, respectively, whereas supplementation allows increases of 22 and 44\%, respectively.

\section{CONCLUSIONS}

The use of silage supplementation presented a positive economic and productive effect on the final live weight of the animals, regardless of the stocking rate.

Increasing the stocking rate up to 2.5 steers ha $^{-1}$ is feasible if winter supplementation is available, independently of a finishing period in the feedlot.

Although it is feasible to increase the stocking rate up to 3 steers ha-1 with the highest live weight gain per hectare $(861 \mathrm{~kg})$, the weight of the animals individually will be lower because of a low availability of pasture, irrespective of the amount of supplementation.

\section{ACKNOWLEDGEMENTS}

This research was funded by FONDECYT Grant 1050740 . 
Table 4. Mean and standard deviation for indices of physical and economic performance of the system as a function of stocking rate and supplementation.

\begin{tabular}{|c|c|c|c|c|c|c|c|}
\hline Stocking rate & $\begin{array}{l}\text { Suplemen- } \\
\text { tation }\end{array}$ & $\begin{array}{c}\text { Final } \\
\text { weight }\end{array}$ & $\begin{array}{l}\text { Total mean } \\
\text { cost per kg } \\
\text { live weight }\end{array}$ & $\begin{array}{l}\text { Operational } \\
\text { mean cost per } \\
\text { kg live weight }\end{array}$ & $\begin{array}{c}\text { Total } \\
\text { income }\end{array}$ & $\begin{array}{l}\text { Operational } \\
\text { income }\end{array}$ & $\begin{array}{c}\text { Live } \\
\text { weight } \\
\text { sales }\end{array}$ \\
\hline Steers ha ${ }^{-1}$ & yes/no & kg steer ${ }^{-1}$ & $-\$$ & $\longrightarrow$ & $\longrightarrow$ millic & $\mathrm{n} \$ \mathrm{Ch}$ & $000^{\prime} \mathrm{kg}$ \\
\hline \multirow{2}{*}{2.0} & no & $496.7 \pm 6.6 b$ & $521.5 \pm 3.4 \mathrm{~b}$ & $433.5 \pm 5.8 \mathrm{a}$ & $29.1 \pm 2.0 \mathrm{~b}$ & $55.3 \pm 2.5 \mathrm{a}$ & $298.0 \pm 4.0 \mathrm{a}$ \\
\hline & yes & $540.4 \pm 3.9 \mathrm{e}$ & $517.8 \pm 2.7 \mathrm{a}$ & $440.7 \pm 3.2 b$ & $32.8 \pm 1.1 \mathrm{c}$ & $57.8 \pm 1.5 b$ & $324.2 \pm 2.4 b$ \\
\hline \multirow[t]{2}{*}{2.5} & no & $468.8 \pm 5.4 \mathrm{a}$ & $543.2 \pm 5.0 \mathrm{c}$ & $457.4 \pm 5.2 \mathrm{~d}$ & $26.6 \pm 2.1 \mathrm{a}$ & $56.8 \pm 2.4 b$ & $351.6 \pm 4.0 \mathrm{c}$ \\
\hline & yes & $533.4 \pm 4.5 \mathrm{~d}$ & $521.6 \pm 5.4 \mathrm{~b}$ & $445.0 \pm 3.7 \mathrm{c}$ & $38.9 \pm 1.7 \mathrm{e}$ & $69.6 \pm 2.1 \mathrm{c}$ & $400.0 \pm 3.4 \mathrm{~d}$ \\
\hline \multirow[t]{2}{*}{3.0} & no & $\mathrm{i}$ & $\mathrm{i}$ & $\mathrm{i}$ & $\mathrm{i}$ & $\mathrm{i}$ & $\mathrm{i}$ \\
\hline & yes & $505.7 \pm 5.3 \mathrm{c}$ & $543.9 \pm 5.2 \mathrm{c}$ & $468.6 \pm 5.0 \mathrm{e}$ & $34.2 \pm 2.7 \mathrm{~d}$ & $68.4 \pm 3.0 \mathrm{c}$ & $455.1 \pm 4.8 \mathrm{e}$ \\
\hline
\end{tabular}

Vertical means with different letters differ significantly $(\mathrm{P} \leq 0.01)$ : i The system is unfeasible without supplementation.

\section{RESUMEN}

Modelación de estrategias de suplementación en la recría y engorda de novillos en el Sur de Chile. Un modelo matemático fue desarrollado para analizar sistemas de producción de carne bovina en el Sur de Chile. El estudio consideró la identificación de los componentes en diferentes estrategias usadas en novillos de carne, usando praderas con y sin suplementación y la recría seguida por una engorda a corral en invierno con ensilaje de praderas y granos. La validación de los resultados a pradera del modelo usando novillos Hereford de 200 kg PV contra resultados experimentales no mostró diferencias significativas $(\mathrm{P} \geq 0.01)$ entre los pesos finales simulados y los observados. En el estudio, fueron simuladas tres carga animal (CA) de 2, 2.5 y 3 novillos ha $^{-1}$ con y sin suplementación de ensilaje de pradera a una tasa de $5 \mathrm{~kg}^{\mathrm{MS}}$ novillo- día $^{-1}$ durante todo el período de alimentación. Las medias fueron comparadas por Diferencias Significativas Mínimas (LSD, $\mathrm{P} \leq 0.05$ ). Diferencias significativas se encontraron en los pesos finales, que disminuyeron en razón del aumento de la CA independiente del nivel de suplementación, aunque ésta tendió a reducir las diferencias entre las CA. Se simuló además la respuesta de los novillos en el período final de engorda a corral y con una ración base de ensilaje y granos. Los pesos finales difirieron entre CA y los resultados mostraron que la $\mathrm{CA}$ de 2.5 novillos ha-1, entregó el mayor ingreso al menor costo medio. Se concluye que una carga animal de 2.5 novillos ha ${ }^{-1}$ es factible si existe disponibilidad de suplementación, independiente del sistema a corral para la terminación.

Palabras clave: bovinos de carne, suplementación, pastoreo, modelos de simulación.

\section{LITERATURE CITED}

AFRC. 1993. Necesidades energéticas y proteicas de los rumiantes. 175 p. Agricultural and Food Research Council, Zaragoza, España.

Aguilar, C. 1997. Simulación de sistemas. Aplicaciones en producción animal. Colección en Agricultura. 241 p. Pontificia Universidad Católica de Chile, Santiago, Chile.

Aguilar, C.D., R.I. Allende, y J.S. Morales. 2003. Gestión de sistemas pecuarios. Colección en Agricultura. 633 p. Pontificia Universidad Católica de Chile, Santiago, Chile.

Aguilar, C., R. Vera, R. Allende, and P. Toro. 2006. Supplementation, stocking rates, and economic performance of lamb production systems in the Mediterranean-type region of Chile. Small Ruminant Res. 66:108-115.

Catrileo, A., y L. Goic. 2005. Introducción y perspectivas del rubro. In Catrileo, S.A. (ed.) Producción y manejo de carne bovina en Chile. Colección Libros INIA N ${ }^{\mathrm{o}}$ 16. p. 13-27. Ministerio de Agricultura, Instituto de Investigaciones Agropecuarias, Centro Regional de Investigaciones Carillanca, Temuco, Chile.

Catrileo, S.A., y G.G. Klee. 2005. La ganadería de carne en la pequeña agricultura. In Catrileo, S.A. (ed.) Producción y manejo de carne bovina en Chile. Colección Libros INIA No 16. p. 485-496. Ministerio de Agricultura, Instituto de Investigaciones Agropecuarias, Centro Regional de Investigaciones Carillanca, Temuco, Chile.

CSIRO. 1990. Ruminants. Feeding standards for Australian livestock. 266 p. The Australian's Commonwealth Scientific and Industrial Research Organisation, Victoria, Australia. 
Halvorson, M. 2003. Microsoft Visual Basic NET. Version 2003. 135 p. Mc Graw Hill/Interamericana de España, Madrid, España.

Hoover, S.V., and R.F. Perry. 1989. Simulation. A problemsolving approach. 400 p. Addison-Wesley Publishing Company, Reading, Massachussets, USA.

ODEPA. 2001. Compendio estadístico, silvoagropecuario 1990-2000. 169 p. Ministerio de Agricultura, Oficina de Estudios y Políticas Agrarias, Santiago, Chile.

Rojas, C., A. Catrileo, y J.L. Rouanet. 2004. Sistema de recría y engorda con novillos Hereford y cruzas con doble propósito, integrados a una sucesión de cultivos en el valle de la IX Región. p. 147-148. XXIX Reunión Anual Sociedad Chilena de Producción Animal (SOCHIPA), Villarrica, Chile. 13-15 de octubre. SOCHIPA, Santiago, Chile.
Rojas, C., y O. Romero. 1994. Sistema de recría-engorda de novillos Hereford, utilizando festuca con trébol subterráneo, en el valle de la IX Región. Agric. Téc. (Chile) 54:130-135 .

Tattersall. 2006. Sociedad El Tattersall S.A. Ferias de ganado. 17-10-2006. Available at http://www. tattersall-remates.cl (Accessed December 2007). 


\title{
A STUDY OF DAIRY FARM TECHNICAL EFFICIENCY USING META- REGRESSION: AN INTERNATIONAL PERSPECTIVE
}

\author{
Víctor H. Moreira López ${ }^{1 *}$, and Boris E. Bravo-Ureta ${ }^{2}$
}

\begin{abstract}
This paper develops a meta-regression analysis to explain the variation of mean technical efficiency (PETP) measurements from a total of 65 frontier studies that report technical efficiency (ET) measurements at the dairy farm level in the literature published in English and Spanish. The analysis includes the effect of methodology on ET measurements, as well as the effect of the econometric procedure on the meta-regression estimates. Eight models were estimated, and two of these were selected: a fixed effects specification with dummy variables for the most significant studies without geographical effects (EFS), and a specification where the multiple observations are averaged and geographical effects included (OP). Based on model performance, the EFS option is chosen for the analysis. The results of the EFS model suggested that non-parametric deterministic models generate higher PETP estimates than the parametric cases (stochastic and deterministic frontier models). In addition, the Cobb-Douglas and translog forms yield higher average PETP than all other functional forms, cross-sectional data produce higher ET estimates than panel data, and the PETP is higher when the study is input-oriented. The primal approach implies a higher ET estimate than the dual analysis, and when more variables are included in the model, the PETP value is higher.
\end{abstract}

Key words: meta-regression, frontier models, technical efficiency, dairy farms.

\section{INTRODUCTION}

In an environment of growing liberalization, productivity growth, which is a major element of competitiveness, is essential to insure the prosperity of agriculture in general and dairy farming in particular (Sandrey and Scobie, 1994; Pinstrup-Andersen, 2002; Ruttan, 2002). A clear example is New Zealand, which opened its economy to the world market at the beginning of 1984 and then experienced a clear improvement in farm technical efficiency (ET henceforth) (Sandrey and Scobie, 1994; Evans et al., 1996; Paul et al., 2000). This improvement in ET has occurred as New Zealand has experienced a marked increase in the value of dairy products exported (Blayney and Gehlhar, 2005). The measurement of ET is important because it can help in both policy formulation and farm management (Russell and

${ }^{1}$ Universidad Austral de Chile, Instituto de Economía Agraria, Campus Isla Teja, Valdivia, Chile.

"Corresponding author (vmoreira@uach.cl).

${ }^{2}$ University of Connecticut, Department of Agricultural and Resource

Economics, Storrs, 06269, Connecticut, USA.

Received: 25 October 2007.

Accepted: 20 March 2008.
Young, 1983; Kalirajan, 1984; Bravo-Ureta and Rieger, 1991). Producers benefit directly from improvements in their technical performance because more efficient farms tend to generate higher incomes and thus have a better chance of surviving and staying in business (BravoUreta and Rieger, 1991; Dartt et al., 1999; Lawson et al., 2004).

In the past decades, many researchers have developed and applied diverse methods to evaluate ET at the farm level. Battese (1992), and Bravo-Ureta and Pinheiro (1993) reviewed selected articles in order to derive general conclusions about the range of ET and the performance of the methodologies reviewed. Rivas (2003) applied a meta-regression analysis to describe the behavior of ET for a limited group of dairy farm studies listed in selected databases in the English language literature. More recently, Bravo-Ureta et al. (2007) developed a meta-regression analysis of ET measures for all agricultural activities which includes 167 farm level studies from around the world.

In this paper we contribute to the existing literature by undertaking a meta-regression analysis focused on dairy farm ET. Thus, we examine the impact of various attributes of a dairy efficiency study (e.g., estimation technique, functional and sample size, among others) 
on ET estimates. In our analysis we also account for the possible lack of data independence stemming from the presence of multiple observations from the same study.

\section{MATERIALS AND METHODS}

\section{Data collection}

A systematic search was made for dairy farm studies published in both English and Spanish between January 1986 and January 2006 in the following databases: Agricola; Agris International; Econlit; Factiva; Infotrac; Ingenta; JSTOR; ProQuest; Social Science Citation Index; Science Direct; Web of Knowledge; Web of Science; and the World Agricultural Economics and Rural Sociology Abstracts. A complementary search was performed in the following web databases: Blackwell Synergy; EconPapers; Scielo; SpringerLink; and Taylor \& Francis. In addition, a search was performed in the following Spanish language literature sources: Dialnet (online database); Agrociencia (Mexico and Uruguay); Ciencia e Investigación Agraria (Chile); Cuadernos de Economía (Chile and Colombia); Economía Agraria y Recursos Naturales (Spain); Estudios de Economía Aplicada (Spain); Investigación Agraria, Producción y Sanidad Animales (Spain); Producción Animal (Spain); Revista Brasileira de Economía (Brazil); Revista de Análisis Económico (Chile); Revista Española de Estudios Agrosociales y Pesqueros (Spain); and Revista de Estudios Agrosociales (Spain).

\section{Variable Definition and Empirical Models}

The frontier function methodology, as introduced in the path breaking paper published by Farrell just over 50 years ago (1957), uses the efficient unit isoquant to measure economic efficiency (EE), and to decompose this measurement into ET and allocative efficiency (AE). In this model, ET is defined as the ability of the firm to produce maximum output given a set of inputs and the technology. AE measures the success of the firm in choosing the optimal input proportions, i.e., where the ratio of marginal products for each pair of inputs is equal to the ratio of their market prices. In Farrell's framework, EE is a measurement of overall performance and is equal to ET times $\mathrm{AE}(\mathrm{EE}=\mathrm{ET} \times \mathrm{AE})$. These concepts are illustrated in Figure 1, where point $\mathrm{P}$ represents an inefficient firm and the distance QP is the amount by which all inputs could be reduced (proportionally) without lowering output to achieve the technically efficient level of production (point Q). Thus, the ET measurement is equal to the ratio $0 \mathrm{Q} / 0 \mathrm{P}$. Similarly, $\mathrm{AE}$ is equivalent to the ratio $0 \mathrm{R} / 0 \mathrm{Q}$.

The working hypothesis of this paper is that the variation in average farm ET (PETP henceforth) for dairy farms in published studies can be explained by the major attributes of the models used. For this purpose, the following two base models are estimated:

Base Model A: PETP $=f($ PEST, PDET,

$$
\begin{aligned}
& \text { TL, CD, CTR, PROD, } \\
& \text { PRI, VAR, VAROBS) }
\end{aligned}
$$

Base Model B: PETP $=f($ Model A, plus INDIA,

$$
\begin{aligned}
& \text { NAMR, AFRI, } \\
& \text { LATIN, ESTE) }
\end{aligned}
$$

The dependent variable in the meta-regressions is the PETP measurement reported in the studies included in the data set. The independent methodological variables are: PEST, a dummy equal to one if the model is a parametric stochastic frontier, and zero otherwise; PDET, a dummy equal to one if the model is a parametric deterministic frontier, and zero otherwise, the omitted category being non-parametric deterministic studies; TL, a dummy equal to one if the TL functional form is used; $\mathrm{CD}$, a dummy equal to one for the $\mathrm{CD}$ functional form Cobb-Douglas (CD) and the excluded category is other functional forms and non-parametric studies; CTR, a dummy equal to one if the data is cross-sectional, and zero if panel data; PROD, a dummy equal to one if the model is output-oriented, and zero if input-oriented; PRI, a dummy equal to one if a primal model is estimated, and zero for dual models; VAR, the number of explanatory variables; and VAROBS, the ratio between VAR and the number of observations used in a study.

In Base Model $\mathrm{B}$, the following set of regional variables is incorporated: INDIA, which is a regional dummy variable equal to one if the study used data for that part of the world, and zero otherwise; NAMR, a dummy equal to one if the data comes from North America (United States and Canada), and zero otherwise; AFRI, a dummy equal to one if the study used data from Africa, and zero

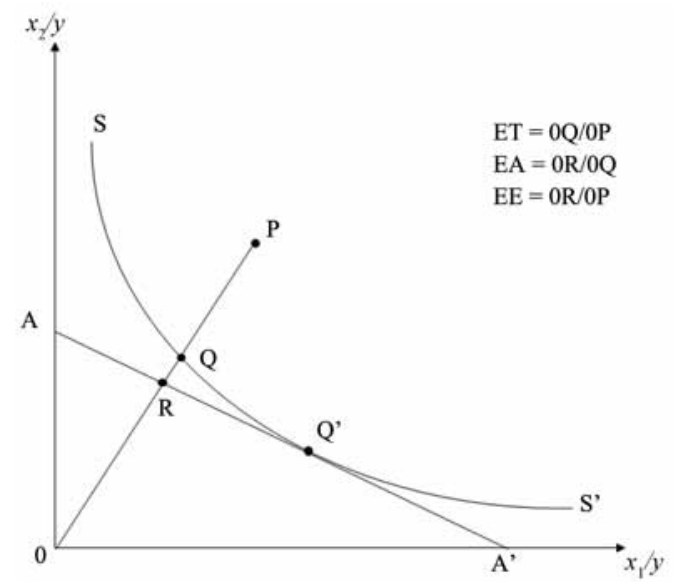

Source: Coelli et al. (2005).

Figure 1. Technical (ET), allocative (EA) and economic efficiency (EE) for an input oriented model. 
otherwise; LATIN, a dummy equal to one if the study used data from Latin America, and zero otherwise; and, ESTE, a dummy equal to one if the study used data from Eastern Europe, and zero otherwise. The omitted regions are Western Europe and Oceania.

Meta-studies often incorporate articles that include several observations, which gives rise to a potential lack of independence in the data because studies with a higher number of observations have more weight in the analysis (Anderson and Weitz, 1989; Van Den Bergh et al., 1997). Several econometric procedures have been proposed to deal with this issue. Phillips (1994) applied fixed effects, while Verlegh and Steenkamp (1999) used a two step process following a procedure suggested by Anderson and Weitz (1989). Another approach is to average the data according to some specified criteria (Espey et al., 1997; Verlegh and Steenkamp, 1999; Johnston et al., 2003; Hunter and Schmidt, 2004). Including a dummy variable to capture the study (fixed) effect to address the multi author problem (Anderson and Weitz, 1989) has been criticized by Verlegh and Steenkamp (1999), who argue that incorporating study dummies in a meta-regression model is likely to introduce severe multicollinearity. To avoid the collinearity problem, Anderson and Weitz (1989) suggest a two step procedure. First, the model without study dummies is estimated and the residuals from this step are used as the dependent variable in a second regression. In this second step, the study dummies are regressed on the residuals from the first step using a stepwise procedure. If the residuals are "white noise" then there are no study effects, and if not, then the selected dummies are introduced into the original model, which is re-estimated.

Another problem that arises when studies have multiple estimates, and thus the observations lack independence, is a possible bias in the standard errors of the meta-regression parameters, which would invalidate tests of hypotheses (Espey et al., 1997; Verlegh and Steenkamp, 1999; Johnston et al., 2003; Hunter and Schmidt, 2004). One option to mitigate this problem is to average multiple observations from a given study. This can be done in various ways (Hunter and Schmidt, 2004). In this paper, the presence of multiple PETP is due to the diversity of attributes used in the estimation of ET and all the main attributes are included in the base Models A and B. However, some attributes are incorporated in only a few models within a study and in such cases we average the respective ET measurements.

To deal with the various issues discussed above, three additional models (1,2 and 3) are estimated for each base Model (A and B), yielding a total of eight estimated models: 1) Models with full fixed effects; 2) Models with selected fixed effects; and 3) Models with averaged multiple observations. Models with full fixed effects and with selected fixed effects include a set of dummy variables that are defined for each study that reports two or more PETP estimates. Each study dummy is equal to 1 for all the observations that belong to a given study, and zero otherwise. Models with full fixed effects include all study dummies available, while models with selected fixed effects include only the selected study dummies following the two step procedure suggested by Anderson and Weitz (1989), as previously detailed.

ET scores are bounded between zero and one; thus, the two-limit Tobit procedure should be used (Greene, 2003). However, the meta-analysis literature focusing on ET in the agricultural sector reports similar results for the Tobit and Ordinary Least Square (OLS) procedures. Another consideration articulated by Stanley and Jarrell (1989) is that meta-regression studies use different data sets, different sample sizes, and different independent variables, which suggest that the variances of the meta-regression coefficients may not be equal, which implies that metaregression errors are likely to be heteroskedastic. Therefore, in the current study all meta-regressions are estimated using White's heteroskedastic consistent covariance matrix estimation to correct the estimates for an unknown form of heteroskedasticity. This procedure is readily available in the Shazam Econometrics Software (Whistler et al., 2001) and has been used in other meta-analysis work (Johnston et al., 2003; Bravo-Ureta et al., 2007).

\section{RESULTS AND DISCUSSION}

The literature search generated a total of 65 published papers which contain the type of information required for the present research. Because many of the papers report multiple ET estimates, the meta-dataset consists of a total of 329 observations. Table 1 presents an overview of all papers used in this assessment, including the authors, year of publication, country, and the PETP reported. In addition, all these papers are classified by the methodology implemented in the studies. To simplify the table, for studies that report more than one estimate using the same methodology, the average figures are included.

Table 2 presents the methodological features of the studies included in this research. As indicated, a total of 65 studies are included out of which 38 apply deterministic models and 33 stochastic models. It is important to mention that the total number of papers with stochastic and deterministic models (71) is larger than the reported number of papers (65) because in some studies both techniques are implemented. All studies combined yield a total of 329 observations given that, as already stated, some authors report multiple estimates. The data show a similar number of observations and studies that use 
Table 1. Overview of empirical studies of average mean technical efficiency (PETP) for dairy farms.

\begin{tabular}{|c|c|c|c|}
\hline Author(s). (Year). Journal, Country ${ }^{1}$ & $\begin{array}{c}\text { Number of } \\
\text { measurements }^{2}\end{array}$ & $\begin{array}{l}\text { Sample size } \\
\text { (Number of } \\
\text { farms) }\end{array}$ & $\begin{array}{c}\text { PETP } \\
(\%)\end{array}$ \\
\hline \multicolumn{4}{|l|}{ I. No-Parametric } \\
\hline \multicolumn{4}{|l|}{ Deterministic frontier } \\
\hline Arzubi and Berbel (2001), Rev. Esp. Estud. Agrosoc. Pesq., Argentina & 3 & 35 & 77.8 \\
\hline Arzubi and Berbel (2002), Invest. Agrar. Prod. Sanid. Anim., Argentina & 6 & 42 & 87.5 \\
\hline Arzubi et al. (2004), Rev. Argent. Econ. Agrar., Argentina & 1 & 45 & 90.5 \\
\hline Asmild et al. (2003), J. Prod. Anal., Netherlands & 2 & 1808 & 80.5 \\
\hline Cloutier and Rowley (1993), Can. J. Agric. Econ., Canada & 2 & 187 & 89.8 \\
\hline Fraser and Cordina (1999), Agric. Syst., Australia & 6 & 50 & 88.5 \\
\hline González et al. (1996), Invest. Agrar. Econ., Spain & 8 & 56 & 77.9 \\
\hline Jaforullah and Whiteman (1999), Aust. J. Agric. Resour. Econ., New Zealand & 1 & 264 & 89.0 \\
\hline Kaliba (2004), Q. J. Int. Agric., Tanzania & 8 & 240 & 75.9 \\
\hline Lachaal et al. (2002), Mediterr. J. Econ. Agric. Environ., Tunisia & 1 & 17 & 68.0 \\
\hline Mathijs and Vranken (2001), Post Communist Econ., Hungary & 3 & 26 & 42.3 \\
\hline Pardo et al. (2002), Empir. Econ. Lett., Spain & 5 & 38 & 65.2 \\
\hline Piesse et al. (1996), J. Comp. Econ., Slovenia & 4 & 272 & 86.0 \\
\hline Reinhard et al. (2000), Eur. J. Oper. Res., Netherlands & 8 & 1535 & 79.7 \\
\hline Silva et al. (2004), New Medit, Portugal & 2 & 122 & 66.6 \\
\hline Tauer (1993), Agric. Resour. Econ. Rev., USA & 2 & 395 & 78.3 \\
\hline Tauer (1998), J. Agric. Econ., USA & 6 & 630 & 90.0 \\
\hline Thirtle et al. (1996), J. Prod. Anal., Slovenia & 34 & 136 & 77.9 \\
\hline Thomas and Tauer (1994), Can. J. Agric. Econ., USA & 4 & 125 & 89.2 \\
\hline Weersink et al. (1990), Can. J. Agric. Econ., Canada & 1 & 105 & 94.9 \\
\hline Average & & & 78.8 \\
\hline \multicolumn{4}{|l|}{ Stochastic frontier } \\
\hline Haghiri et al. (2004), Appl. Econ., Canada & 12 & 1021 & 58.2 \\
\hline Average & & & 58.2 \\
\hline
\end{tabular}

\section{Parametric}

\section{Deterministic frontier}

Ahmad and Bravo-Ureta (1996), J. Prod. Anal., USA

Álvarez et al. (1988), Rev. Estud. Agro-soc., Spain

Álvarez and González (1999), Am. J. Agric. Econ., Spain

Álvarez and Arias (2004), Agric. Econ., España

Arias and Álvarez (1993), Invest. Agrar. Econ., Spain

Bravo-Ureta (1986), Can. J. Agric. Econ., USA.

Bravo-Ureta and Rieger (1990), J. Agric. Econ., USA

El-Osta and Morehart (2000), Rev. Agric. Econ., USA

Haghiri and Simchi (2003), Empir. Econ. Lett., USA.

Hallam and Machado (1996), Eur. Rev. Agric. Econ., Portugal

Karagiannis et al. (2002), J. Prod. Anal., U.K.

Lachaal et al. (2003), Eur. Assoc. Anim. Prod., Tunisia

Maietta and Sena (2000), Eur. Rev. Agric. Econ., Italy

Orea et al. (2004), J. Prod. Anal., Spain 
Continuated Table 1.

Poe and Jones (1992), J. Am. Soc. Farm Manag. Rural Appraisers, USA

Richards and Jeffrey (2000), J. Agric. Resour. Econ., USA

$4 \quad 675$

Tauer and Belbase (1987), Northeastern J. Agric. Resour. Econ., USA

74.8

Turk (1995), Zb. Bioteh. Fak. Univ. Ljubl. Kmet. Supl., Slovenia

$1 \quad 181$

94.2

1432

69.3

Average

2

272

78.0

\section{Stochastic frontier}

Ahmad and Bravo-Ureta (1996), J. Prod. Anal., USA

Arias and Álvarez (1993), Invest. Agrar. Econ., Spain

70.1

Bailey et al. (1989), West. J. Agric. Econ., Ecuador

Battese and Coelli (1988), J. Econom., Australia

Bravo-Ureta and Rieger (1990), J. Agric. Econ., USA

Bravo-Ureta and Rieger (1991), Am. J. Agric. Econ., USA

Brümmer and Loy (2000), J. Agric. Econ., Germany

Brümmer (2002), Am. J. Agric. Econ., Germany, Netherlands and Poland

Cuesta (2000), J. Prod. Anal., Spain

Dawson (1987), Eur. Rev. Agric. Econ., U.K.

Dawson (1988), Oxf. Agrarian Stud., U.K.

Dawson (1990), Oxf. Agrarian Stud., U.K.

Dawson and Wales (1990), Appl. Econ., U.K.

Dawson and Woodford (1991), Oxf. Agrarian Stud., U.K.

Ghosh et al. (1994), Forecast. Soc. Change, USA

Haghiri and Simchi (2003), Empir. Econ. Lett., USA

Hallam and Machado (1996), Eur. Rev. Agric. Econ., Portugal

Heshmati (1998), Appl. Econ., Sweden

Heshmati and Kumbhakar (1994), J. Prod. Anal., Sweden

Jaforullah and Deblin (1996), N. Z. Econ. Pap., New Zealand

Kumbhakar et al. (1989), Rev. Econ. Stat., USA

Kumbhakar et al. (1991), J. Bus. Econ. Stat., USA

Kumbhakar and Heshmati (1995), Am. J. Agric. Econ., Sweden

Lawson et al. (2004), Livest. Prod. Sci., Denmark

Lawson et al. (2004), J. Dairy. Sci., Denmark

Mbaga et al. (2003), Can. J. Agric. Econ., Canada

Moreira López et al. (2006), Arch. Med. Vet., Chile

Pierani and Rizzi (2003), Agric. Econ., Italy

Reinhard et al. (1999), Am. J. Agric. Econ., Netherlands

Reinhard et al. (2000), Eur. J. Oper. Res., Netherlands

Reinhard and Thijssen (2000), Eur. Rev. Agric. Econ., Netherlands

Saha and Jain (2004), Indian J. Agric. Econ., India

\begin{tabular}{ll}
\hline Average & 83.3 \\
\hline OVERALL AVERAGE & 78.4 \\
\hline
\end{tabular}

${ }^{1}$ Full citations are not presented to save space and are available upon request from the authors. Journal titles are presented using ISO (International Organization for Standardization) abbreviations.

${ }^{2}$ Several studies report various measurements of ET stemming from the application of different methods. 
Table 2. Summary of empirical studies of average mean technical efficiency (PETP) for dairy farms.

\begin{tabular}{|c|c|c|c|c|c|}
\hline Category & $\mathbf{N}^{0}$ Obs. & $\mathbf{N}^{0}$ Studies $^{1}$ & $\begin{array}{c}\text { Deterministic } \\
\text { Average } \\
\text { (Min-Max) }\end{array}$ & $\begin{array}{c}\text { Sthocastic } \\
\begin{array}{c}\text { Average } \\
\text { (Min-Max) }\end{array}\end{array}$ & PETP $^{1}$ \\
\hline \multicolumn{6}{|l|}{ Approach } \\
\hline Parametric & 210 & 46 & $70.1 \quad(40.0-94.2)$ & 83.3 (47.9-99.8) & 79.4 \\
\hline Non-Parametric & 119 & 21 & $78.8(39.0-100.0)$ & $58.2(42.0-69.0)$ & 76.7 \\
\hline \multicolumn{6}{|l|}{ Data } \\
\hline Panel & 207 & 30 & $75.6 \quad(46.0-94.2)$ & $79.7(42.0-99.8)$ & 77.7 \\
\hline Cross Sectional & 122 & 35 & $75.5(39.0-100.0)$ & $84.9(47.9-96.6)$ & 79.6 \\
\hline \multicolumn{6}{|l|}{ Functional form ${ }^{1}$} \\
\hline Cobb-Douglas & 72 & 22 & $73.0(40.0-94.2)$ & $79.8(47.9-92.5)$ & 77.9 \\
\hline Translog & 114 & 21 & $69.5(49.0-85.6)$ & $85.9(60.9-99.8)$ & 81.2 \\
\hline Others & 24 & 5 & $65.6(46.0-79.7)$ & $81.3(61.8-96.6)$ & 75.4 \\
\hline \multicolumn{6}{|l|}{ Returns to scale } \\
\hline Constant & 129 & 39 & $75.3(39.0-100.0)$ & $76.3(42.0-95.0)$ & 75.8 \\
\hline Variable & 200 & 38 & 75.7 (46.0-94.9) & $85.0(60.9-99.8)$ & 80.1 \\
\hline \multicolumn{6}{|l|}{ Orientation } \\
\hline Output & 202 & 48 & $73.1 \quad(40.0-94.9)$ & $81.5(42.0-99.8)$ & 78.7 \\
\hline Input & 127 & 26 & $77.2(39.0-100.0)$ & $80.8(61.8-95.0)$ & 77.9 \\
\hline \multicolumn{6}{|l|}{ Technology representation } \\
\hline Primal & 282 & 54 & $75.6(39.0-100.0)$ & $83.1(42.0-99.8)$ & 78.9 \\
\hline Dual & 47 & 11 & $75.6 \quad(49.0-94.2)$ & $75.5(47.9-88.5)$ & 75.5 \\
\hline \multicolumn{6}{|l|}{ Language } \\
\hline English & 303 & 58 & $75.1(39.0-100.0)$ & $81.7(42.0-99.8)$ & 78.4 \\
\hline Spanish & 26 & 7 & $79.3(40.0-92.5)$ & $73.8(69.0-82.0)$ & 78.0 \\
\hline \multicolumn{6}{|l|}{ Geographical region } \\
\hline Africa & 10 & 3 & $75.1 \quad(58.7-86.4)$ & & 75.1 \\
\hline India & 8 & 1 & & $90.2(86.6-92.5)$ & 90.2 \\
\hline Latin America & 16 & 5 & $84.9 \quad(76.9-92.9)$ & $73.2(69.0-78.1)$ & 80.5 \\
\hline North America ${ }^{3}$ & 89 & 19 & $78.8(45.9-100.0)$ & $75.9(42.0-96.6)$ & 77.1 \\
\hline Eastern Europe & 47 & 4 & $74.5 \quad(39.0-93.0)$ & & 74.5 \\
\hline Western Europe and Oceania & 159 & 33 & $73.2(40.0-90.8)$ & $84.2(60.9-99.8)$ & 79.7 \\
\hline Total average & & & $75.6(39.0-100.0)$ & $81.4(42.0-99.8)$ & 78.4 \\
\hline Number of observations & & & 169 & 160 & 329 \\
\hline Number of studies ${ }^{2}$ & & & 38 & 33 & 65 \\
\hline
\end{tabular}

${ }^{1}$ Valid for parametric approach only.

${ }^{2}$ Several studies report various measurements of ET stemming from the application of different methods.

${ }^{3}$ North America includes the USA and Canada.

deterministic (169 observations) and stochastic models (160 observations). The PETP for all deterministic models is $75.6 \%$ compared to $81.4 \%$ for all stochastic models and this mean difference is statistically significant at $5 \%$. In addition, most of the studies rely on the translog (TL) functional form, are output-oriented and are mainly published in English (58 out of 65).

Table 2 also summarizes the PETP measurements according to the geographical region where the studies were conducted. Western Europe and Oceania have the largest number of observations (159 in 33 studies), followed by North America (89 in 19 studies), Eastern Europe (47 in four studies), Latin America (16 in five studies), Africa (10 in three studies) and India (eight in one study). The highest PETP, when stochastic and deterministic studies are combined, is for India $(90.2 \%)$, while the lowest is for Eastern Europe (74.5\%). 
Table 3. Meta-regressions of mean technical efficiency (PETP) for dairy farms.

\begin{tabular}{|c|c|c|}
\hline Variables & $\begin{array}{l}\text { Selected fixed } \\
\text { effects (EFS) }\end{array}$ & $\begin{array}{c}\text { Averaged } \\
\text { model (OP) }\end{array}$ \\
\hline \multirow[t]{2}{*}{ Constant } & $67.524 * * *$ & $72.169 * * *$ \\
\hline & $3.520^{\mathrm{a}}$ & 4.725 \\
\hline \multirow[t]{2}{*}{ PEST, parametric stochastic frontier } & -6.857 & 2.908 \\
\hline & 4.256 & 5.006 \\
\hline \multirow[t]{2}{*}{ PDET, parametric deterministic frontier } & $-18.855 * * *$ & $-9.098 *$ \\
\hline & 3.994 & 4.922 \\
\hline \multirow[t]{2}{*}{$\mathrm{TL}$, translog } & $13.059 * * *$ & 2.770 \\
\hline & 4.469 & 5.575 \\
\hline \multirow[t]{2}{*}{$\mathrm{CD}$, Cobb-Douglas } & $15.117 * * *$ & 2.653 \\
\hline & 4.244 & 4.834 \\
\hline \multirow[t]{2}{*}{ CTR, cross-sectional } & $2.426 * *$ & -1.706 \\
\hline & 1.213 & 2.471 \\
\hline \multirow[t]{2}{*}{ PROD, output-oriented } & $-2.456 *$ & -3.688 \\
\hline & 1.256 & 2.852 \\
\hline \multirow[t]{2}{*}{ PRI, primal model } & $9.137 * * *$ & 4.673 \\
\hline & 2.968 & 3.449 \\
\hline \multirow[t]{2}{*}{ VAR, number of explanatory variables } & $0.240 * * *$ & $0.264 *$ \\
\hline & 0.082 & 0.150 \\
\hline \multirow[t]{2}{*}{ VAROBS, ratio between VAR and the number of observations } & 3.546 & -5.107 \\
\hline & 2.571 & 7.681 \\
\hline \multirow[t]{2}{*}{ INDIA, India } & & $14.378 * *$ \\
\hline & & 6.721 \\
\hline \multirow[t]{2}{*}{ NAMR, North America } & & $6.244 * *$ \\
\hline & & 2.821 \\
\hline \multirow[t]{2}{*}{ AFRI, Africa } & & 0.535 \\
\hline & & 5.866 \\
\hline \multirow[t]{2}{*}{ LATIN, Latin America } & & 5.595 \\
\hline & & 4.277 \\
\hline \multirow[t]{2}{*}{ ESTE, Eastern Europe } & & $-9.700 * *$ \\
\hline & & 4.380 \\
\hline Log-likelihood & -1.098 .5 & -450.7 \\
\hline $\mathrm{R}^{2}$ & 0.6754 & 0.3726 \\
\hline Adj. $\mathbf{R}^{2}$ & 0.6329 & 0.2897 \\
\hline
\end{tabular}

*** Significant at $1 \% ; * *$ Significant at $5 \%$; Significant at $10 \%$.

${ }^{\text {a }}$ Figures in italics are robust standard errors.

PEST, dummy used if the model is a parametric stochastic frontier or not; PDET, dummy used if the model is a parametric deterministic frontier or not; TL, dummy used if the TL functional form is used; CD, dummy used for the CD functional form or not; CTR, dummy used if the data is cross-sectional or not; PROD, dummy used if the model is output-oriented or not; PRI, dummy used if a primal model is estimated or not; VAR, the number of explanatory variables; VAROBS, the ratio between VAR and the number of observations used in a study; INDIA, regional dummy variable if the study used data for that part or theworld or not; NAMR, dummy used if the data comes from North America (United States and Canada) or not; AFRI, dummy used if the study used data from Africa or not; LATIN, dummy used if the study used data from Latin America or not; and ESTE, dummy used if the study used data from Eastern Europe or not. 
A preliminary analysis reveals that the two preferred options are the Selected Fixed Effects Model (Model EFS) that includes methodological variables, without geographical variables, and the Averaged Observations Model (Model OP) that incorporates both methodological and geographical variables. These two models are not nested, so no further formal statistical comparisons among them are undertaken. The parameters for both of theses models are included in Table 3 and a simple comparison of the number of significant parameters and adjusted $\mathrm{R}^{2}$ reveals that model EFS is clearly superior to model OP. Therefore, the following analysis of the results is based on model EFS. Additional information for all models can be obtained directly from the authors.

The variables PEST and PDET capture the effect of the methodology used to estimate the frontier on PETP estimates where the excluded category for this group of dummies is the non-parametric approach. Model EFS has a negative parameter for PEST while in Model OP it is positive, but in both cases it is non significant. Theoretically, a positive value is expected for the parameter for PEST, given that deterministic models assume that all deviations from the frontier represent inefficiency (Coelli et al., 2005). The estimated parameter for PDET suggests that parametric deterministic models yield lower PETPs than non-parametric models, which is valid in both models. This finding is also consistent with a priori expectations (Kumbhakar and Lovell, 2000). Thiam et al. (2001) found a negative and significant parameter for stochastic models compared to deterministic models in their research using 34 studies covering only developing countries. Bravo-Ureta et al. (2007) found a negative and significant parameter for both the parametric stochastic and deterministic models when compared with the nonparametric approach in their research using 167 studies on farming.

The TL and CD specifications are statistically significant in Model EFS, but not for Model OP. The CD and TL yield higher PETPs than other functional forms. These results suggest that the functional form has an unclear effect on PETP, which is consistent with what has been reported by Ahmad and Bravo-Ureta (1996), Resti (2000), and Bravo-Ureta et al. (2007), among others.

The parameter for CTR (Cross Sectional data) is positive and significant in Model EFS, which is consistent with the averages shown in Table 2, while the PROD parameter (orientation of the model) is negative. Thus, these findings suggest that frontier models using an output-oriented approach produce lower PETP estimates than models based on an input-oriented approach. Neither Thiam et al. (2001) nor Bravo-Ureta et al. (2007) include this variable in their meta-regressions.
Model EFS has a positive parameter for PRI, suggesting that the question of whether the model relies on a primal (PRI) or dual representation of the technology can have a significant effect on PETP. By contrast, BravoUreta et al. (2007) found a non-significant effect for this variable.

The results indicate that the parameter for VAR (number of explanatory variables) is positive and significant and VARSIZE (ratio between the number of explanatory variables and the number of observations) is also positive but not significant. Thomas and Tauer (1994) reported an increase in the ET measurements in a non-parametric analysis when the number of variables is increased, which is consistent with the Bravo-Ureta et al. (2007) findings. In general and as would be expected, these results indicate a positive association between PETP and model dimensionality (Chavas et al., 2005).

\section{CONCLUSIONS}

The empirical and the conceptual literature contain mixed results and contradictory views concerning the virtues of the various methodologies that have been developed to measure technical efficiency. This paper organizes studies originating from an extensive body of literature that has been published in English and Spanish over the past few decades on dairy farm ET. A total of 65 studies that use frontier models report PETP measurements at the farm level, and all the variables required for the estimated models are included. These studies yielded 329 observations, given that some report several PETP estimates.

Eight alternative models were estimated and several tests indicate that two of them perform better than the rest and thus are selected for further analysis. These two models are the selected fixed effects (model EFS) and the averaged multiple observations (model OP). Further analysis of the performance of these two models indicates that the EFS model is superior to the OP model. Thus, the results confirm the importance of considering the effect of multiple observations in the estimation of a metaregression analysis.

The main results of the EFS model suggest that nonparametric deterministic models generate higher PETP estimates than the parametric cases (stochastic and deterministic frontier models). Within the parametric studies, the deterministic approach produces lower ET figures than the stochastic approach. The effect of functional form on ET is significant and the CD and TL forms yield higher average ET than all other functions. Frontier models based on cross-sectional data produce higher estimates than those based on panel data. In addition, the orientation of the study (input or output) has a 
significant effect, with a higher PETP measurement being found for the input-oriented cases. The primal approach implies a higher ET estimate than the dual analysis. Finally, the dimensionality of the model is relevant and when more variables are included in the model, a higher PETP value is reported.

\section{RESUMEN}

Un estudio de eficiencia técnica en lecherías usando meta-regresión: Una perspectiva internacional. El objetivo de este estudio es realizar un análisis de metaregresión para explicar la variación en el promedio de eficiencia técnica predial (PETP) en 65 estudios, en la literatura en inglés y español, desarrollados con datos a nivel predial y que reportan medidas de eficiencia técnica (ET). El estudio analiza tanto el efecto de la metodología empleada en la medición de la ET como el procedimiento econométrico en la estimación de la meta-regresión. Se estimaron ocho modelos de los cuales se escogieron dos: efectos fijos seleccionados (EFS) que incluye variables metodológicas y variables dummy para los estudios más significativos, y observaciones promediadas (OP) que contiene tanto variables metodológicas como geográficas. Basado en su comportamiento, se eligió el primer modelo para el análsis. Los resultados del modelo EFS sugieren que las fronteras determinísticas no-paramétricas generan PETP más altos que las paramétricas estocásticas y determinísticas. Las formas funcionales Cobb-Douglas y translogarítmica generan PETPs más altos que otras formas funcionales, datos de corte transversal producen valores de ET más altos que los de panel, y el PETP es más alto cuando el estudio es orientado al insumo. Análisis basados en el primal revelan valores promedios de ET más altos que en el dual, y un mayor número de variables incluidas en el modelo implica un PETP mayor.

Palabras clave: meta-regresión, modelos de frontera, eficiencia técnica, lecherías.

\section{LITERATURE CITED}

Ahmad, M., and B.E. Bravo-Ureta. 1996. Technical efficiency measures for dairy farms using panel data: A comparison of alternative model specifications. J. Prod. Anal. 7:399-415.

Anderson, E., and B. Weitz. 1989. Determinants of continuity in conventional industrial channel dyads. Marketing Sci. 8:310-323.

Battese, G.E. 1992. Frontier functions and technical efficiency: A survey of empirical applications in agricultural economics. Agric. Econ. 7:185-208.
Blayney, D.P., and M.J. Gehlhar. 2005. U.S. Dairy at a new crossroads in a global setting. Amber Waves 3:1-6.

Bravo-Ureta, B.E., and A.E. Pinheiro. 1993. Efficiency analysis of developing country agriculture: A review of the frontier function literature. Agric. Resour. Econ. Rev. 22:88-101.

Bravo-Ureta, B.E., and L. Rieger. 1991. Dairy farm efficiency measurement using stochastic frontiers and neoclassical duality. Am. J. Agric. Econ. 73:421-428.

Bravo-Ureta, B.E., D. Solís, V.H. Moreira, J.F. Maripani, A. Thiam, and T.E. Rivas. 2007. Technical efficiency in farming: A meta-regression analysis. J. Prod. Anal. 27:57-72.

Coelli, T.J., D.S.P. Rao, C.J. O'Donnell, and G.E. Battese. 2005. An introduction to efficiency and productivity analysis. 349 p. $2^{\text {nd }}$ ed. Springer, New York, USA.

Chavas, J.P., R. Petrie, and M. Roth. 2005. Farm household production efficiency: Evidence from the gambia. Am. J. Agr. Econ. 87:160-179.

Dartt, B.A., J.W. Lloyd, B.R. Radke, J.R. Black, and J.B. Kaneene. 1999. A comparison of profitability and economic efficiencies between managementintensive grazing and conventionally managed dairies in Michigan. J. Dairy Sci. 82:2412-2420.

Espey, M., J.A. Espey, and W. Shaw. 1997. Price elasticity of residential demand for water: A meta-analysis. Water Resour. Res. 33:1369-1374.

Evans, L., A. Grimes, B. Wilkinson, and D. Teece. 1996. Economic reform in New Zealand 1984-95: The pursuit of efficiency. J. Econ. Lit. 34:1856-1902.

Farrell, M.J. 1957. The measurement of productive efficiency. J. R. Stat. Soc. 120:253-290.

Greene, W.H. 2003. Econometric analysis. 1026 p. $5^{\text {th }}$ ed. Pearson Education Pte. Ltd., Delhi, India.

Hunter, J.E., and F.L. Schmidt. 2004. Methods of metaanalysis: Correcting error and bias in research findings. 582 p. $2^{\text {nd }}$ ed. Sage Publications, Thousand Oaks, California, USA.

Johnston, R.J., E.Y. Besedin, and R.F. Wardwell. 2003. Modeling relationships between use and nonuse values for surface water quality: A meta-analysis. Water Resour. Res. 39:1363-1372.

Kalirajan, K.P. 1984. Farm-specific technical efficiencies and development policies. J. Econ. Stud. 11:3-13.

Kumbhakar, S.C., and C.A.K. Lovell. 2000. Stochastic frontier analysis. 348 p. Cambridge University Press, New York, USA.

Lawson, L.G., J. Bruun, T.J. Coelli, J.F. Agger, and M. Lund. 2004. Relationships of efficiency to reproductive disorders in Danish milk production: A stochastic frontier analysis. J. Dairy Sci. 87:212-224. 
Paul, C.J.M., W.E. Johnston, and G.A.G. Frengley. 2000. Efficiency in New Zealand sheep and beef farming: The impacts of regulatory reform. Rev. Econ. Stat. 82:325-337.

Phillips, J.M. 1994. Farmer education and farmer efficiency: A meta-analysis. Econ. Dev. Cult. Change 43:149-165.

Pinstrup-Andersen, P. 2002. Food and agricultural policy for a globalizing world: Preparing for the future. Am. J. Agric. Econ. 84:1201-1214.

Resti, A. 2000. Efficiency measurement for multiproduct industries: A comparison of classic and recent techniques based on simulated data. Eur. J. Oper. Res. 121:559-578.

Rivas, T.E. 2003. Dairy farm efficiency and the analysis of milk production growth: Evidence from vermont. 162 p. Ph.D. Dissertation. University of Connecticut, Storrs, Connecticut, USA.

Russell, N.P., and T. Young. 1983. Frontier production functions and the measurement of technical efficiency. J. Agric. Econ. 34:139-150.

Ruttan, V.W. 2002. Productivity growth in world agriculture: Sources and constraints. J. Econ. Perspect. 16:161-184.
Sandrey, R.A., and G.M. Scobie. 1994. Changing international competitiveness and trade: Recent experience in New Zealand agriculture. Am. J. Agric. Econ. 76:1041-1046.

Stanley, T.D., and S.B. Jarrell. 1989. Meta-regression analysis: A quantitative method of' literature surveys. J. Econ. Surv. 3:161-170.

Thiam, A., B.E. Bravo-Ureta, and T.E. Rivas. 2001. Technical efficiency in developing country agriculture: A meta-analysis. Agric. Econ. 25:235-243.

Thomas, A.C., and L.W. Tauer. 1994. Linear input aggregation bias in nonparametric technical efficiency measurement. Can. J. Agric. Econ. 42:77-86.

van den Bergh, J.C.J.M., K.J. Button, P. Nijkamp, and G.C. Pepping. 1997. Meta-analysis in environmental economics. 240 p. Kluwer Academic Publishers, Netherlands.

Verlegh, P.W.J., and J.-B.E.M. Steenkamp. 1999. A review and meta-analysis of country-of-origin research. J. Econ. Psych. 20:521-546.

Whistler, D., K.J. White, S.D. Wong, and D. Bates. 2001. Shazam user's reference manual version 9.558 p. $2^{\text {nd }}$ ed. Quebecor World, Quebec, Canada. 


\title{
ADMINISTRATION AND MANAGEMENT OF IRRIGATION WATER IN 24 USER ORGANIZATIONS IN CHILE
}

\author{
Jorge Jara ${ }^{*}$, Marco A. López ${ }^{1}$, Álvaro San Martín², Luis Salgado ${ }^{\text {, and Ovidio Melo }}{ }^{1}$
}

\begin{abstract}
Approximately $85 \%$ of the water consumed in Chile is destined to agricultural irrigation and is managed by the users themselves. This study analyzed the price that irrigation water users pay to their Water User Associations (WUAs) to which they belong and the relationship of this price to the professional level and performance of the WUAs. The study included 24 WUAs: 10 River Administration Boards (JV) and 14 Irrigation Canal Associations (AC). The annual operational budget of each WUA, the price paid by users and the management capacities of the board of directors of each WUA were compared. The study also determined the relative value of user payments to WUAs as a proportion of total production costs of the main crops in each zone. The variability of user fees per irrigated hectare decreases when the irrigation area of the WUA is more than 10000 ha, though this was not observed in JVs. The presence of technical-professional staff directly affects the development and growth of the WUAs. As well, the WUAs with a greater level of capacity development (NDC) have more board members with a higher education level and have lower rates of unpaid user fees. The price that users pay to the WUA by irrigated hectare represents less than $4.0 \%$ of the average total production cost of the main crops in the study area. Finally, no correlation was found between the prices that users pay and the average profitability of the main crops, or between price and the geographical location of the WUAs.
\end{abstract}

Key words: water cost, water users associations, WUAs, water canal associations, river administration board.

\section{INTRODUCTION}

In different countries in Latin America and the Caribbean there are efforts to encourage changes in legislation and organizations related to the management and use of water for irrigation. These reforms vary from one country to another in terms of their execution, progress and content (Garduño, 2003, Huamanchumo et al., 2008). Brazil, Chile, Colombia, Jamaica and Mexico have reformed the institutional character of water management, while the majority of other countries are in the process of making legal and institutional changes (Jouravlev, 2001).

Approximately 85\% of water consumed in Chile is used in agricultural irrigation (Ministry of Public Work-General Water Directorate, 1999), a resource that is administered by the users themselves through organizations recognized

${ }^{1}$ Universidad de Concepción, Facultad de Ingeniería Agrícola, Casilla 537, Chillán, Chile. *Corresponding author (jcjara@udec.cl).

${ }^{2}$ Dirección General de Aguas, Unidad de Administración de Recursos Hídricos, Caupolicán s/n Edificios Públicos $3^{\text {er }}$ piso Of. 7, Los Ángeles, Chile (alvaro.sanmartin.s@mop.gov.cl).

Received: 16 May 2008.

Accepted: 20 August 2008. by law and with their own regulations and autonomous boards of directors.

The costs assumed by users for irrigation water services in the majority of Latin American countries have not been analyzed in-depth. In fact, some works have been carried out in recent years related to valuing irrigation water that tangentially address the cost of the service. Notably, there are works to estimate the economic and/or environmental value of irrigation water by Dinar (2000) cited by Çakmak et al. (2004), Herrera et al. (2004), Garrido et al. (2007) and Huamanchumo et al. (2008).

Water resources in Chile are the responsibility of the General Water Directorate, a body under the Ministry of Public Works, which grants water use rights without cost for the user. Nevertheless, the catchment, conduction and distribution of water resources, which imply administrative and operational costs, are the responsibility of Water User Associations (WUAs). These are regulated by the Water Code and have the objective of administering water sources and works through which water resources are extracted, captured and/or conducted and distributed among users. As well, they are responsible for resolving conflicts among such users (Galaz, 2004).

The Water Code (Republic of Chile, 2006) defines three types of organizations: (1) River Administration 
Boards (JV), (2) Irrigation Canal Associations (AC) and (3) Water Communities. JVs are constituted on the basis of natural water sources, including ground water. ACs are constituted on the basis of artificial water sources, normally canal networks of multi-farm irrigation systems. Water Communities are constituted on the basis of artificial water sources and distribute water according to the user rights of their members.

According to the CPA-SIGIRH-V8.03 Information System of the Public Water Registry of the General Water Directorate, there are currently $39 \mathrm{JVs}$ and 168 ACs registered, which in general have professionalized their administration and comply with the functions they are charged with under existing legislation. At the same time, there are 3218 water communities registered at the national level, the majority of which are weak in technical, legal, administrative, financial and operational aspects, and with low levels of management and serious problems in intake, conduction and distribution of water resources. They have not developed institutional networks and are characterized by high levels of conflict (Melo et al., 2005). As well, there are a number of additional organizations, especially among water communities, which operate informally and do not fully exercise their legal rights (Galaz, 2004).

There are WUAs in Chile that administer water for large areas under irrigation (> $30000 \mathrm{ha}$ ) without having permanent engineers or technical staff, and at the same time there are others smaller WUAs with one or more professional staff, without a clear or direct relationship between the fees user have to pay to their organization (Melo et al., 2005). The success of the latter has been based mainly on the capacity to professionalize the administration of the organization. As well, the support team (engineers, lawyers, technicians and accountants) carries out activities on behalf of the organization's board of directors, such as improving the quality of the service, earning extra incomes and implementing systems of gradual penalties to reduce the rate of unpaid user fees and other practices against the interests of the users.

Given this, it is estimated that a small WUA, without professional support would have difficulty in meeting all its obligations. This suggests that there is a minimum irrigation surface area under the responsibility of a WUA that makes it economically viable for the WUA to professionalize itself, taking into consideration agroclimatic and sociocultural factors.

The objective of this work was to analyze the cost that users should pay based on administration, operation and management in 24 WUAs and the relationship to the level of professionalization, management capacity and performance of these organizations and their impact on production costs.

\section{MATERIALS AND METHODS}

Twenty-four WUAs (JV and AC) from the Coquimbo to the Bio-Bio Regions were studied. The WUAs studied were willing to share their financial records, budget for the irrigation season of 2005-2006 and information about the total surface area under irrigation that they administer, as well as geographic maps and information about the administrative characteristics of the organization. The initial stage of the study was interviews with representatives of each organization (members of boards of directors, managers or administrators) with the objective of obtaining primary information. As well, a semi-structured interview was applied to the members of the boards of directors with the objective of relating their characteristics of age, years in the position, participation, contact with other organizations and educational level, among others, that can influence the functioning of the WUA. Finally, secondary information was evaluated to determine if there was a correlation between the profitability of the crops that predominate in the areas of jurisdiction of these organizations and the price that users pay for the administration of the irrigation system. The research stage and information gathering was carried out from April to June of 2006.

The level of prices and costs presented by the WUAs were evaluated, for the period of May 2005 to April 2006. The exchange rate used of $\$ 541.7$ Chilean pesos per US dollar was estimated based on data published by the Central Bank of Chile (2008), considering the average rate of exchange for the period indicated, which presented a standard deviation of $\$ 24.2$ pesos.

\section{Primary information}

This refers to the economic resources used during the irrigation season of 2005-2006 in each of the organizations evaluated, identifying or recovering administrative and operational costs, highlighting among others the operation of irrigation intakes structures, cleaning canals and professional or administrative fees. As well, this includes information related to technical and administrative aspects of the organization such as the total area under irrigation, the number of water right allotments under the jurisdiction and water resources that are managed.

The information related to the leadership capacity and performance of the board of directors of each organization was gathered by means of semi-structured interviews conducted with members of 19 of the 24 boards of the WUAs that agreed to participate in this part of the study.

\section{Secondary information}

This refers to bibliographic information available on the surface area destined to the main crops in the areas of the study (Larrañaga et al., 2003; 2004; 2005; 2006), their 
proportional participation in each WUA and information about the total production costs and average gross margin (Fundación Chile, 2007).

\section{Characterization of the WUAs}

To characterize the WUA an instrument termed the Capacities Development Level (NDC) was used. It was designed by the National Irrigation Commission in collaboration with the Universidad de Concepción (de Miguel, 2005). It allows for classifying, characterizing and typifying the WUAs into seven categories according to the development of their management and administrative capacities, legal situation, participation of users and other organizational aspects (Table 1). Field trips were made to each WUA and members of the boards of directors, technical staff and users were interviewed and selfevaluation test (San Martín, 2007) was applied.

\section{Calculating the annual budget}

Subsequent to the information gathering stage, a study was prepared on the operational expenses of WUAs, the resources used and administrative costs, including among others, security personnel, accountant and clerical staff, as well as the fees of professionals who render managerialadministrative and legal-technical services, infrastructural and operational expenses to maintain the functioning of the system such as upkeep of inlets and cleaning. The gathering and analysis of these data allowed for estimating the annual budget necessary for the functioning of the WUAs according to:

\section{Annual budget $=$ Administration costs + Operational costs + Investments}

Administrative expenses include salaries (administrator, engineer, accountant, secretary, guard, benefits, bonuses, insurance and others), fees (engineer, lawyer, accountant and that are not core staff), office rental, office materials and basic services (telephone, fax, internet, electricity, water, radio), vehicle or transportation (fuel and maintenance). Operational expenses refer to the opening and closing of inlets structures, support to the JV if it corresponds, cleaning of canals, maintenance, security staffs, machine rental, trucking and transport. Investments include construction, repairs and repositioning of works and contingencies.

The total amount collected (MTR) annually by the WUA is:

$$
\text { MTR }=\text { MRC }+ \text { Grants }+ \text { Others }
$$

where MRC is the amount collected through user fees of the organization in a season ( $\$$ season $^{-1}$ ), Grants refers to the amount obtained ( $\$$ season $^{-1}$ ) through projects presented under Law $\mathrm{N}^{\circ} 18450$ for the promotion of private investment in irrigation and drainage works, and Other considers judicial fees and extraordinary improvement programs.

\section{Determination of cost per hectare}

With the amount collected by the users fees charged to users of the system (MRC) and the total area under irrigation administered by the WUA (SBR), the price paid by user to irrigate one hectare of land $(P P U)$, is expressed as:

$$
P P U=\frac{M R C}{S B R}\left(\$ \text { ha }^{-1} \text { season }^{-1}\right)
$$

The choice of $P P U$ instead of the price for nominal flow (water right allocated as a part of the canal flow) that the user pay is due to the lack of correspondence observed between the values of the water right allotments and the water discharges that they represent, which is characteristic of and unique to each WUA (Table 2). As well, reliable water measurements are not always available throughout the irrigation seasons for all the participating WUAs, which would allow for obtaining an average seasonal water flow or fair estimation of the volume of water that corresponds to a water right allotment. Nevertheless, all the organizations have reliable and detailed information about the irrigation area under their jurisdiction, because of which, for comparative purposes, the PPU is adequate.

\section{Production costs, average gross margin and price paid by users}

To obtain the proportion of the cost of the administration cost of the water in the total cost of the main crops in territories of the respective WUAs, databases were reviewed with information on the main crops, based on the fruit registry of the ODEPA-CIREN (Larrañaga et al., 2003; 2004; 2005; 2006). Likewise, the weighted profitability of the areas under irrigation was estimated using information on production costs, gross incomes, profitability or average gross margin (Fundación Chile, 2007), and it was determined whether there was a correlation between this parameter and the value paid by users for the administration of water resources in their system.

\section{RESULTS AND DISCUSSION}

\section{Characterization of the WUAs}

Of the 24 WUAs considered, 10 were JVs and 14 ACs (Table 2). Thus, of the total of $39 \mathrm{JVs}$ and 168 ACs registered at the national level, $25.6 \%$ of the JVs and $8.3 \%$ of the ACs were included in the study. The total study represented $11.6 \%$ of the total of JVs and ACs registered in the country. Each WUA manages an irrigation system that covers more than 2500 ha, the largest being the Maule 
Table 1. Level of Capacity Development (NDC) of the Water User Associations (WUAs).

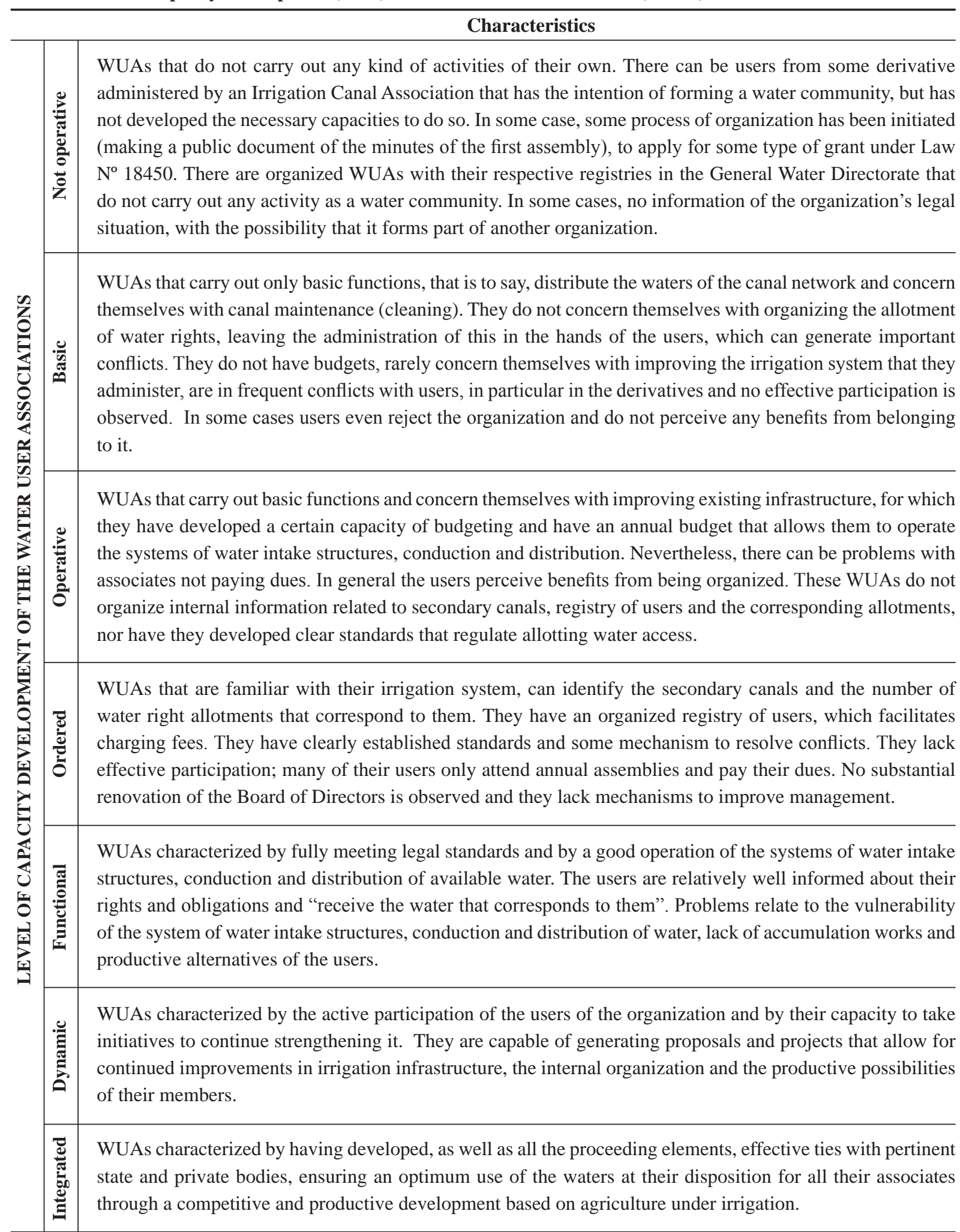

Source: Final Report “Development of a Methodology of Organization and Training for Water Communities”. Agreement between the National Irrigation Commission and the Universidad de Concepción, Faculty of Agricultural Engineering, January 2003 (de Miguel, 2005). 
Table 2. Nominal discharge managed $(\mathrm{Qn})$, nominal discharge per water right allotment $\left(\mathrm{Q}_{\mathrm{Acc}}\right)$ and area under irrigation (SBR) in 25 Water User Associations (WUAs) surveyed.

\begin{tabular}{|c|c|c|c|c|}
\hline Region & Name of the WUA & $Q_{n}\left(m^{3} s^{-1}\right)$ & $Q_{\text {Acc }}\left(L^{-1}\right.$ acc $\left.^{-1}\right)$ & SBR (Mha) \\
\hline \multirow{6}{*}{ 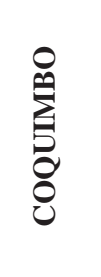 } & AC Punitaqui Canal & 0.82 & 1.0 & 2.7 \\
\hline & JV Illapel River & 0.40 & 1.0 & 3.5 \\
\hline & JV Combarbalá River & 3.61 & 1.0 & 2.5 \\
\hline & JV Choapa River & 18.26 & 1.0 & 10.7 \\
\hline & JV Limarí and Grande Rivers and streams & 24.59 & 1.0 & 20.5 \\
\hline & JV Elqui River & 25.34 & 1.0 & 23.5 \\
\hline $\mathbf{R M}$ & AC del Maipo & 19.96 & 15.0 & 30.0 \\
\hline \multirow{3}{*}{ 吊 } & JV Cachapoal River $1^{\text {a }}$ Section & - & - & 48.0 \\
\hline & AC San Pedro Población y Derivados Canal & 7.36 & 2.7 & 2.7 \\
\hline & AC Cachapoal Canal & 3.68 & 14.1 & 5.0 \\
\hline \multirow{6}{*}{ 恐 } & JV Achibueno River & 19.96 & 1.5 & 12.0 \\
\hline & AC Putagán Canal & 4.29 & 1.0 & 20.0 \\
\hline & AC Maule Norte Canal & 51.78 & 15.0 & 70.0 \\
\hline & AC Maule Sur & 34.40 & 1.4 & 25.0 \\
\hline & JV Ancoa River and streams & 7.42 & 1.0 & 9.0 \\
\hline & JV Maule River & 199.98 & 1.4 & 180.6 \\
\hline \multirow{8}{*}{ 음 } & AC del Laja & 68.49 & 15.0 & 55.0 \\
\hline & AC Zañartu Canal & 29.18 & 10.0 & 40.0 \\
\hline & JV Diguillín River and streams & 33.39 & 15.1 & 33.0 \\
\hline & AC Bío-Bío Norte Canal & 10.70 & 15.0 & 10.0 \\
\hline & AC Bío-Bío Negrete Canal & 17.98 & 15.9 & 8.0 \\
\hline & Coihueco Reservoir Irrigators Association & 4.96 & 1.1 & 5.0 \\
\hline & AC Duqueco Cuel Canal & 7.97 & 1.4 & 6.0 \\
\hline & AC Quillón Canal & 2.29 & 1.0 & 2.5 \\
\hline
\end{tabular}

JV: River Administration Board; AC: Irrigation Canal Association; RM: Metropolitan Region; LBO: Libertador General Bernardo O’Higgins Region; acc: Water right allocated proportional to the river or canal discharge; Mha: Thousands of hectares.

River JV which distributes the resource to five ACs in the Maule Region, covering an area under irrigation of 180 636 ha, while the largest AC (the North Maule Canal) covers 70000 ha under irrigation.

The 24 WUAs analyzed present various legal situations (owners of the waterway or in the process of receiving control of the canal from the State, without legal status, etc.) and diversity in terms of their organizational management. As well, there is great variability in terms of the number of water right allotments and flow discharge, surface area under irrigation that they manage, geographic location and presence of technical personnel in charge of administration. This becomes into a broad range of levels of development of capacities (NDC).

All these organizations have an administrative system and defined operational structure that coincides with its statutes, established standards and the rights and duties of the users, with a clear identification and register of its members that is periodically updated and includes, among other things, the name, identification number, address and number of allotment holders. About $75 \%$ of the WUAs file copies of the registration of Water Use Rights in their respective Land Registry Office.

Among the WUAs analyzed there are different systems of water use rights: consumptive, permanent, and eventual rights. All of the WUAs prepare an annual budget, in which the board of directors and users participate actively in the decision making. In $100 \%$ of the WUAs the board of directors is elected, with an annual change of an average of $48 \%$ of the members. Likewise, there are annual work plans in which decisions are taken about improving infrastructure and which encourage the participation and attendance at meetings of the users. As well, in the case that the organizations have professional staff in charge of administration, training programs are carried out for members of the board of directors and for the technical and administrative teams. Finally, the NDC of the WUAs is in the range of Basic to Integrated, and 
those organizations with mayor NDC in most cases have an internal accounting system, conduct administration in their own offices, have means of transport and have lower percentages of unpaid user fees, with values that fluctuate between 0 and $20 \%$ (Figure 1). These values are comparable to the $20 \%$ reported by Molle et al. (2008) in the Jordan Valley irrigation system, the 15\% in WUAs from the coastal region of Peru (Huamanchumo et al., 2008) and the 14\% in WUAs in Turkey (Özlü et al., 2000 cited by Çakmak et al., 2004). On the other hand, the WUAs with lower NDCs have rates of unpaid user fees of up to $55 \%$.

\section{Price paid by the user (PPU)}

In general, the ACs charge users higher prices than JVs, which is explained by the fact that JVs perform more restricted functions than ACs, limiting themselves to delivering a supply of water to the irrigation intakes of the canals under their jurisdiction. Figure 2 shows the broad variability of the PPU, oscillating between $\$ 2665$ (US\$4.9) and \$18 706 (US\$34.5) per hectare irrigated in the season, when the AC administers less than 10000 ha. For larger surface areas, a tendency in the ACs is observed to values between $\$ 1648$ (US\$3.0) and $\$ 7286$ (US\$13.5) per hectare irrigated in the season. For the JVs, the PPU oscillates mainly between $\$ 240$ (US\$0.4) and \$3950 (US\$12.8) per hectare-season (the value of \$240 is not shown in Figure 2, and correspond to a WUA that administers 180600 ha, which is outside the range of the graph). The exception is a JV from the Coquimbo Region, with a PPU of $\$ 9287$ (US\$17.1) per hectare, which administers a complex system of 23500 ha and includes two water reservoirs with a total capacity on the order of 240 million $\mathrm{m}^{3}$. As well, this organization is developing a series of projects related to integrated water management and catchment, as well as education in rural schools of the province.

The PPU values obtained in this study are comparable to the price range for irrigation water per hectare, per year or season in Brazil (US\$3.5), Australia (US\$0.75 to 2.3), New Zealand (US\$6.8 to 16.6) and less than those from Mexico (US\$33 to 60), Italy (US\$21 to 78), Spain (US\$96 to 164.5), Greece (US\$92 to 210) (Dinar, 2000 cited by Çakmak et al., 2004).

\section{Professionalization of WUAs}

Some $62.5 \%$ of the WUAs surveyed (15) have permanent administrative staff, while $37.5 \%$ (9) do not. Nevertheless, $91.7 \%$ (22) uses the services of an accountant, whether as permanent or on contract and $54.2 \%$ (13) have contracted and regularly draw upon professional legal services. In relation to staff for technical support (agronomists and engineers), 62.5\% of the WUAs (15) have permanent staff, 20.8\% (5) contract technical support staff in the irrigation season or for specific consultations, and the rest $16.7 \%$ (4) do not have this type of support. As well, $20.8 \%$ (5) has managerial-administrative and technical-legal support that has allowed them to form parallel companies (consulting, administration or construction), responsible for managing and carrying out investment projects in the irrigation system.

Figure 3 offers a way to visualize the relationship between the degree of professionalization of the WUAs and the extra incomes obtained, where the benefits of having professional staff time are appreciable. It follows that the WUAs that contract more than 25 professional hours per week for administrative management or that are directed by an administrator who also exercises technical functions, have obtained resources that fluctuate between MM\$234 to MM\$2823. For this analysis, 22 WUAs were considered because two ACs are in the process of transferring the intake, conduction and distribution structures from the State to the users, which limits them from applying to public funding instruments.

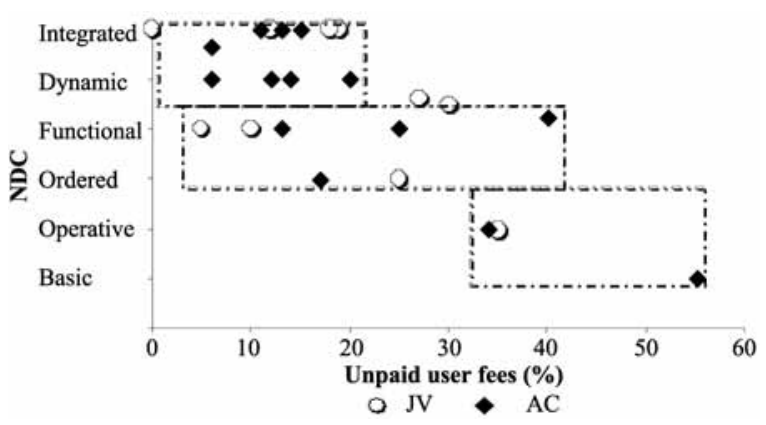

Figure 1. Relationship between the level of capacity development (NDC) and unpaid user fees in 10 River Administration Boards (JV) and 14 Irrigation Canal Associations (AC).

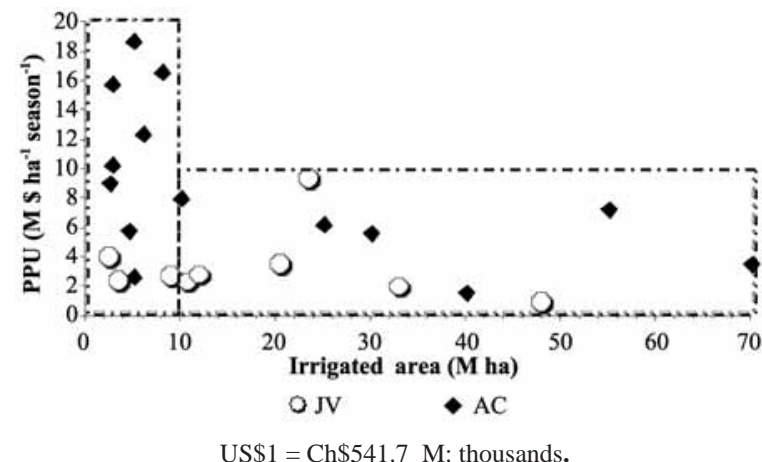

Figure 2. Price paid by users (PPU) depending on irrigated area administrated by nine River Administration Boards (JV) and 14 Irrigation Canal Associations (AC). 
The percentage that the contracting of professional-administrative support of the total amount collected (MTR) by the WUAs is relatively low (Table 3). In the JVs that manage areas under irrigation greater than 30000 ha, the cost of professional services does not exceed $16 \%$, representing values of $\$ 80$ to $\$ 250 \mathrm{ha}^{-1}$ season $^{-1}$. Nevertheless, in the JVs that irrigate from 10000 to 30000 ha, such costs constitute only 8\%, equivalent to $\$ 165$ to $\$ 309$ ha $^{-1}$ season $^{-1}$ (San Martín, 2007).

The ACs that manage areas under irrigation larger than 30000 ha, salaries of core staff represent $7 \%$ of the MTR in a season (Table 4), representing \$400 to \$480 ha $^{-1}$ season $^{-1}$, and in the ACs that irrigate from 10000 to 30000 ha and from 2500 to 10000 ha it represents $6 \%$ and $15 \%$, respectively, which implies values in the range from $\$ 400$ to $\$ 2025$ ha $^{-1}$ season $^{-1}$ (San Martín, 2007).

\section{Analysis of the interviews with members of Boards of Directors}

In 19 of the 24 WUAs to which the interviews were applied $50 \%$ of the members of the board of directors are between 40 and 60 years of age and $43 \%$ are over 60 . About $96 \%$ of the members of the board of directors are male. The term of office of the board members, whether in positions as president, secretary or director, is not related to the NDC. While many WUAs establish regulations that stipulate the annual renewal of the board of directors or part of it, the fact that this change is not complied with does not mean that a WUA lacks an effective system of administration. Additionally, $52 \%$ of the WUAs that responded to the interviews do not have an annual change of the board of directors or part of it. Some larger and successful organizations prefer to conserve their directors because of the good management work they carry out. Nevertheless, other WUAs in the same category conserve part of the board of directors and carry out a partial change in accordance with the established by-law.

The directors of all WUAs with areas under irrigation larger than 10000 ha, have some type of participation in other organizations, whether of a social or productive nature, exercising some position or participating as a member. Some of these organizations are other WUAs, fruit companies, producers' organizations or others. The smaller organizations also relate to other organizations, notably among them other WUAs, agricultural associations and neighborhood associations. It can be

Table 3. Percentage use distribution by items of the total amount collected (MTR) in 10 River Administration Boards, by range of surface area.

\begin{tabular}{|c|c|c|c|}
\hline \multirow[b]{2}{*}{ Item } & \multicolumn{3}{|c|}{ Average of the MTR by range of surface area (ha) } \\
\hline & $2500-10000$ & $10000-30000$ & 30000 and more \\
\hline & & $\%$ & \\
\hline Professional-administrator fees & - & 8 & 16 \\
\hline Core staff salaries & 39 & 33 & 15 \\
\hline General expenses & 24 & 24 & 7 \\
\hline $\begin{array}{l}\text { Others (investment, operational maintenance and transport, } \\
\text { machinery rental and consulting, travel, etc.) }\end{array}$ & 37 & 34 & 62 \\
\hline Total & 100 & 100 & 100 \\
\hline
\end{tabular}

Table 4. Percentage use distribution by items of the total amount collected (MTR) in 14 Irrigation Canal Associations, by range of surface area.

\begin{tabular}{lcrr}
\hline & \multicolumn{3}{c}{ Average of the MTR by range of surface area (ha) } \\
\cline { 2 - 4 } Item & $\mathbf{2 5 0 0 - 1 0 ~ 0 0 0}$ & $\mathbf{1 0 ~ 0 0 0 - 3 0 ~ 0 0 0}$ & $\mathbf{3 0 ~ 0 0 0}$ and more \\
\hline & 15 & 6 & 7 \\
Professional-administrator fees & 29 & 25 & 39 \\
Contracts and wages (cleaning) & 19 & 32 & 37 \\
Core staff salaries & 8 & 6 & 5 \\
General expenses & 29 & 31 & 13 \\
Others (investment, operational maintenance and transport, & & & 100 \\
$\quad$ machinery rental and consulting, travel, etc.) & 100 & 100 & \\
Total & & & \\
\hline
\end{tabular}


deduced that in the larger organizations, the directors or users have a higher level of participation in other types of organizations, whether productive or social. Nevertheless, this indicator does not necessarily represent a better quality of management of the WUA by the directors.

The results of this study indicate that higher levels of formal education of the members of the board of directors can favor the development of the organization (Figure 4), because of which this criterion can be used as a component of the NDC of the WUAs. On the other hand, no relationship was found between the NDC and SBR administered by the WUA, nor with the renewal of the board of directors, nor with the number of water right allotments that the members of the board have.

The WUAs that have contracted professional hours show a minimum value of "Ordered" in their NDC, but when there are no professional hours contracted, the WUAs show a maximum value of "Operative" in their NDC (Figure 5). This has validity discarding an AC with zero professional hours and a "Functional" NDC, given that it received professional support for three years as part of a program for strengthening WUAs (Ministry of Agriculture-National Irrigation Commission, 2006).

\section{Relationship between the PPU and gross margin of production}

The factors that have more influence on direct production costs are inputs like fertilizers, pesticides, labor, harvesting and machinery use (Fundación Chile, 2007). By relating the value that users pay to the WUAs to the average total production cost of the main crops of the zones under study, it can be concluded that this value (PPU) represents less than $4 \%$ of the total production cost of these crops (Table 5). This value is significantly less if it is compared to the $12 \%$ average that represents the irrigation costs in two areas in India, which are derived from the information shown by Kumar et al. (2008)

There was no evidence of any kind of a correlation between the price paid by users (PPU) and the average gross margin (Figure 6), independent of the type of WUA or its geographic location.

\section{CONCLUSIONS}

During the 2005-2006 irrigation season, the price paid by users oscillated between $\$ 2700$ (US $\$ 5.0$ ) and $\$ 18700$ (US\$34.5) ha ${ }^{-1}$ season $^{-1}$, with considerable variability for areas of less than 10000 ha, and values between $\$ 1700$ (US\$3.1) and \$7300 (US\$13.5) ha ${ }^{-1}$ season $^{-1}$ for larger areas. In the JVs, the price paid by users varied between $\$ 240$ (US $\$ 0.4$ ) and $\$ 9300$ (US $\$ 17.2$ ) ha ${ }^{-1}$ season $^{-1}$, without relating them to the area under irrigation that the WUA administers.

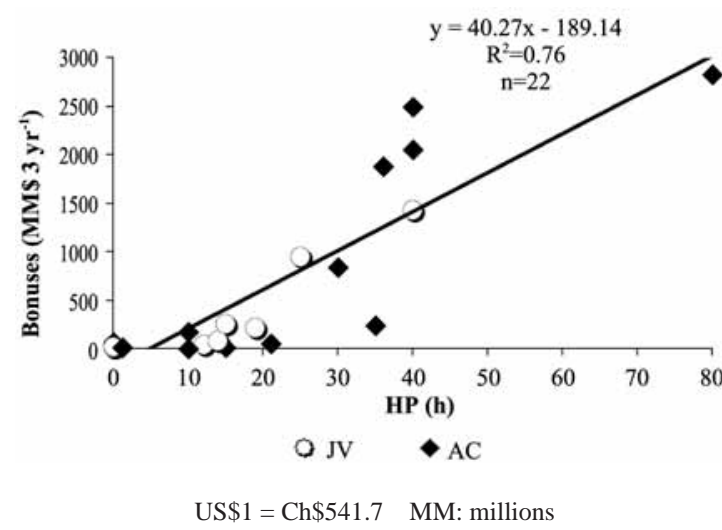

Figure 3. Extra income obtained as bonuses between 2003 and 2005 and weekly professional time (HP) hired in 10 River Administration Boards (JV) and 14 Irrigation Canal Associations (AC) (four JVs and one ACs are in the origin).

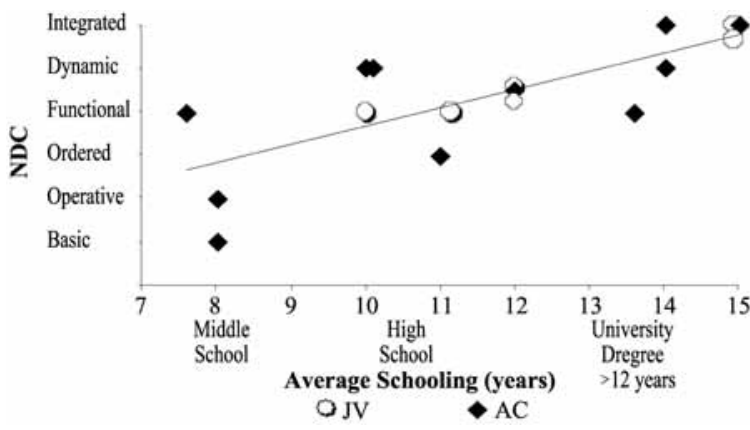

Figure 4. Relationship between Level of Capacity Development (NDC) and average schooling of the council members in seven River Administration Boards (JV) and 12 Irrigation Canal Associations (AC) surveyed.

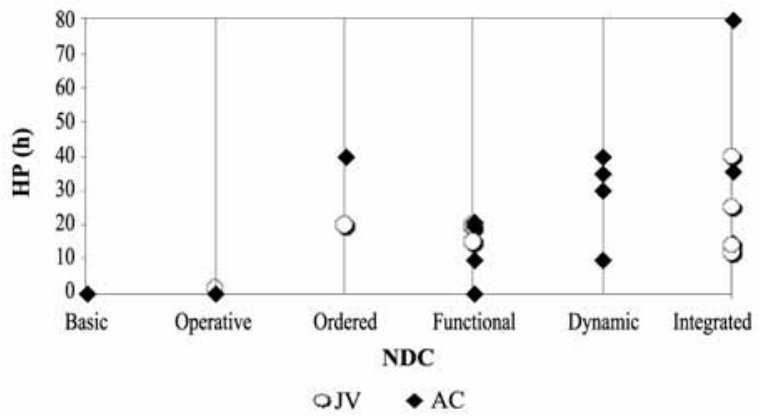

Figure 5. Weekly professional time and Level of Capacity Development (NDC) in 10 RiverAdministration Boards (JV) and 14 Irrigation Canal Associations (AC). 
Table 5. Percentage representation of the value paid by the users (PPU) of River Administration Boards (JV) and Irrigation Canal Association (AC) in the total production cost for the main crops in the irrigated areas under their jurisdiction.

\begin{tabular}{|c|c|c|c|c|c|c|c|c|c|c|c|c|c|c|c|c|}
\hline \multirow[b]{2}{*}{ Region } & \multirow[b]{2}{*}{ Water user organization } & \multicolumn{15}{|c|}{ Representation PPU (\%) } \\
\hline & & $\frac{\text { Ë }}{3}$ & $\frac{0}{2}$ & 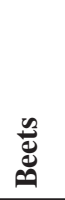 & $\frac{\mathscr{n}}{20}$ & है & ڤ్ & 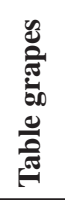 & 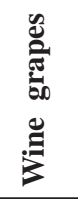 & 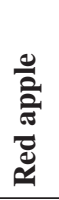 & : & 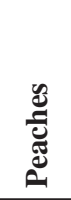 & 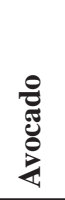 & 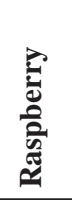 & 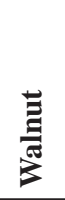 & 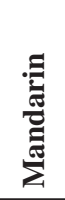 \\
\hline \multirow{6}{*}{ 足 } & AC Punitaqui Canal & & & & & & & 1.0 & & & & & 1.5 & & 1.0 & \\
\hline & JV Illapel River & & & & & & & & & & 0.2 & 0.2 & 0.2 & & 0.2 & \\
\hline & JV Combarbalá River & & & & & & & 0.2 & & & 0.3 & & 0.4 & & 0.4 & \\
\hline & JV Choapa River & & & & & & & & & & 0.2 & 0.2 & 0.2 & & 0.2 & \\
\hline & JV Limarí and Grande Rivers and streams & & & & & & & 0.2 & & & 0.3 & & 0.3 & & & 0.3 \\
\hline & JV Elqui River & & & & & & & 0.5 & & & 1.0 & & 1.0 & & & 0.9 \\
\hline $\mathbf{R M} A$ & AC del Maipo & 1.5 & 0.6 & & & 0.9 & & 0.3 & & & 0.5 & 0.5 & 0.6 & & 0.5 & \\
\hline \multirow{3}{*}{ O] } & JV Cachapoal River $1^{\text {a }}$ Section & 1.0 & & & & 0.6 & 0.7 & 0.2 & 0.5 & 0.2 & & & & & & \\
\hline & AC San Pedro Población y Derivados Canal & 3.5 & & & & 2.6 & 3.3 & 1.0 & 2.4 & 0.8 & & & & & & \\
\hline & AC Cachapoal Canal & 4.0 & & & & 3.1 & 3.8 & 1.5 & 2.8 & 1.0 & & & & & & \\
\hline \multirow{6}{*}{ 你 } & JV Achibueno River & 0.6 & 0.3 & 0.1 & 0.7 & 0.5 & 0.6 & & & 0.2 & & & & 0.1 & & \\
\hline & AC Putagán Canal & 1.3 & 0.7 & 0.3 & 1.5 & 1.0 & 1.2 & & & 0.3 & & & & 0.3 & & \\
\hline & AC Maule Canal & 0.8 & 0.4 & 0.2 & 0.9 & 0.6 & 0.8 & & & 0.2 & & & & 0.2 & & \\
\hline & AC Maule Sur & 1.4 & 0.7 & 0.3 & 1.5 & 1.0 & 1.3 & & & 0.3 & & & & 0.3 & & \\
\hline & JV Ancoa River and streams & 0.6 & 0.3 & 0.1 & 0.6 & 0.4 & 0.6 & & & 0.1 & & & & 0.1 & & \\
\hline & JV Maule River & 0.1 & 0.0 & 0.0 & 0.1 & 0.0 & 0.1 & & & 0.0 & & & & 0.0 & & \\
\hline \multirow{8}{*}{. } & AC del Laja & 2.0 & 0.8 & 0.3 & & 1.2 & 1.5 & & & & & & & & & \\
\hline & AC Zañartu Canal & 0.5 & 0.2 & 0.1 & & & 0.4 & & & & & & & & & \\
\hline & JV Diguillín River and streams & 0.5 & 0.2 & 0.1 & & & 0.5 & & & & & & & & & \\
\hline & AC Bío-Bío Norte Canal & 1.8 & 0.9 & 0.4 & & & 1.7 & & & & & & & & & \\
\hline & AC Bío-Bío Negrete Canal & 3.8 & 1.9 & 0.8 & & 2.7 & 3.5 & & & & & & & & & \\
\hline & $\begin{array}{l}\text { Asociación de Regantes del Embalse Coihueco } \\
\text { Reservoir Irrigators Association }\end{array}$ & 0.6 & 0.3 & 0.1 & & & 0.6 & & & & & & & & & \\
\hline & AC Duqueco Cuel Canal & 2.8 & 1.4 & 0.6 & & 2.0 & 2.6 & & & & & & & & & \\
\hline & AC Quillón Canal & 2.0 & 1.0 & 0.4 & & & 1.9 & & & & & & & & & \\
\hline
\end{tabular}

Source: Own elaboration. RM: Metropolitan Region. LBO: Libertador General Bernardo O’Higgins Region.

The evaluation of WUAs involved in the study indicates that the administrative management systems differ among organizations of the same type and among the regions under study. Management capacity, measured in terms of the NDC, can be correlated with the average level of schooling of the directors of the WUAs, influencing the percentage of unpaid user fees, in the degree of professionalism or professional hours contracted and the extra incomes that are earned in the WUA. It is observed that the hiring of technical-professional staff in charge of administrative, operational and managerial tasks directly influences the development and growth of the WUA, and provides the tools and vision necessary to obtain extra incomes. The hiring of a professionaladministrator represents between $6 \%$ and $16 \%$ of the total amount collected by the organization, with lower values in WUAs that manage an area under irrigation of 10000 to 30000 ha.

The price paid to WUAs by users represent less than $4 \%$ of the total average cost of production of the main crops in the respective territories and are not related to the incomes generated by the producers or the geographic location of the WUA. 


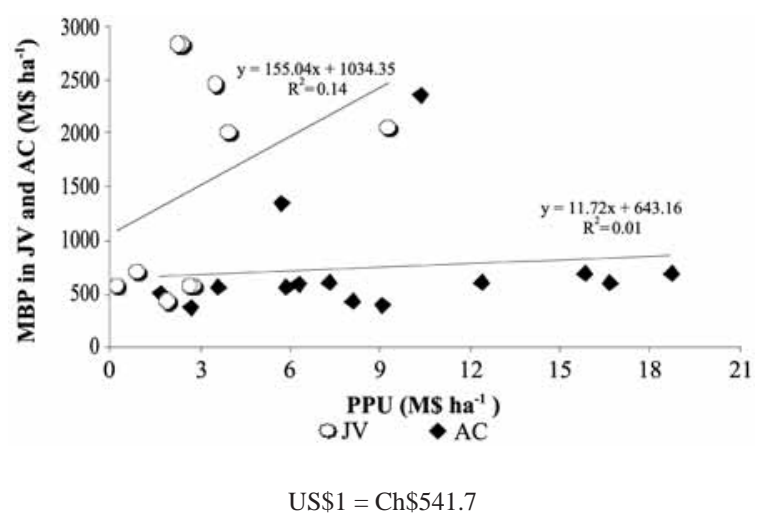

Figure 6. Average gross income margin (MBP) of the area under irrigation in 10 River Administration Boards (JV) and 14 Irrigation Canal Associations and price paid by the users (PPU) for each irrigated hectare.

\section{ACKNOWLEDGEMENTS}

The authors are grateful to the Research Directory of the Universidad de Concepción (DIUC Project $\mathrm{N}^{\circ}$ 208.133.011-1.0), for its funding support to this research. As well, we are grateful for the collaboration of the directors and staff of the River Administration Boards and Irrigation Canal Associations who made this study possible.

\section{RESUMEN}

Administración y gestión del agua de riego en 24 organizaciones de usuarios en Chile. Aproximadamente, el 85\% del agua consumida en Chile es destinada al riego agrícola, siendo administrada por los propios usuarios. En este estudio, se analizó el costo que cancelan los usuarios del agua de riego a sus Organizaciones de Usuarios de Agua (WUAs) y el nivel de profesionalización y desempeño de éstas. Se estudiaron 24 WUAs: 10 Juntas de Vigilancia (JV) y 14 Asociaciones de Canalistas (AC). Se comparó el presupuesto anual de operaciones de cada WUA, el valor que cancelan los usuarios y las capacidades de gestión de la directiva con el desempeño de la respectiva WUA. Además, se analizó la significancia del pago de los usuarios en los costos de producción de los principales cultivos en cada zona. En las AC, la variabilidad de precios por hectárea regada que cancelan los usuarios, disminuye cuando el territorio de la WUA es mayor a 10000 ha, situación no detectada en las JV. El personal técnico-profesional de apoyo incide directamente sobre el desarrollo y crecimiento de las WUAs. Asimismo, las WUAs con nivel de desarrollo de capacidades (NDC) más elevado poseen directivas con mayor escolaridad promedio y los usuarios presentan menor morosidad en el pago. El precio que cancelan los usuarios a las WUAs por hectárea regada representa menos del 4,0\% de los costos promedio totales de producción de los principales cultivos de cada zona. Finalmente, no se evidenció correlación entre el precio que cancelan los usuarios y la rentabilidad promedio de los cultivos, ni por ubicación geográfica de las WUAs.

Palabras clave: costo del agua, organizaciones de usuarios del agua, asociaciones de canalistas, juntas de vigilancia.

\section{LITERATURE CITED}

Banco Central de Chile. 2008. Precio del dólar. Available at http://si2.bcentral.cl/Basededatoseconomicos/951_ 455.asp? $\mathrm{f}=\mathrm{D} \& \mathrm{~s}=\mathrm{UF} \&$ LlamadaPortada $=\mathrm{SI}$ (Accessed 01 April 2008).

Çakmak, B., M. Beyribey, and S. Kodal. 2004. Irrigation water pricing in water user associations. Water Resour. Develop. 20(1):113-124.

De Miguel, L. 2005. Caracterización de las comunidades de agua. Chile Riego 23:29-30.

Fundación Chile. 2007. Programa gestión agropecuaria. Sistemas de producción. Parámetros productivos y de eficiencia. Available at http://www.fundacionchile.cl/ pls/portal/docs/PAGE/PORTAL_CORPORATIVO/ ADMINISTRACION_DEL_CONTENIDO/ AGROINDUSTRIA_FUNDACION_CHILE/HTML/ Agrogestion_Fichas_1.html\#proyecto (Accessed 13 November 2008).

Galaz, V. 2004. Stealing from the poor? Game theory and the politics of water markets in Chile. Environ. Politics 13(2):414-437.

Garduño, H. 2003. Administración de derechos de agua. Experiencias, asuntos relevantes y lineamientos. FAO Estudio Jurídico $\mathrm{N}^{\circ}$ 81. 38 p. FAO, Roma, Italia.

Garrido, A., E. Palacios, J. Calatrava, A. Exebio, J. Chavez, y E. Mejía. 2007. La importancia del valor, costo y precio de los recursos hídricos en su gestión. 87 p. Colegio de Posgraduados de México, México.

Herrera P., G. van Huylenbroeck, R. Espinel, e I. Vanslembrouck. 2004. Valoración económica y economía institucional del agua de riego en la península de Santa Elena-Ecuador. Revista Tecnológica 17(1): 219-229. Available at http://www.rte.espol.edu.ec/ archivos/Revista_2004/27\%20VALORACION\%20E CONOMICA\%20Y\%20ECONOMIA.pdf (Accessed May 2007).

Huamanchumo, J., Y. Peña, L. Silva, and J. Hendriks. 2008. Developing capacity in water users organizations: The case of Peru. Irrig. Drain. 57:300-310. 
Jouravlev, A. 2001. Administración del agua en América Latina y el Caribe en el umbral del siglo XXI. Serie Recursos Naturales e Infraestructura $\mathrm{N}^{\circ} 27.77$ p. CEPAL, Santiago, Chile.

Kumar, M.D., A.K. Malla, and S.K. Tripathy. 2008. Economic value of water in agriculture: Comparative analysis of a water-scarce and water-rich region in India. Water International 33(2):214-230.

Larrañaga, P., L. Yánez, A. Peña, y R. Villa. 2003. Catastro frutícola. Principales resultados VI Región. 50 p. ODEPA-CIREN, Santiago, Chile.

Larrañaga, P., L. Yánez, A. Peña, y R. Villa. 2005. Catastro frutícola. Principales resultados IV Región. 42 p. ODEPA-CIREN, Santiago, Chile.

Larrañaga, P., L. Yánez, y R. Villa. 2004. Catastro frutícola. Principales resultados Región Metropolitana. 50 p. ODEPA-CIREN, Santiago, Chile.

Larrañaga, P., A. Peña, y R. Villa. 2006. Catastro frutícola. Principales resultados VIII Región. 42 p. ODEPACIREN, Santiago, Chile.

Melo, O., G. Carozzi, J. Jara, J. Vial, L. Moreno, y A. Ibarra. 2005. Las comunidades de agua en Chile. Una visión desarrollada a partir del diagnóstico de dichas organizaciones. Universidad de Concepción, Facultad de Ingeniería Agrícola. Documento presentado en el XX Congreso Nacional del Agua y III Simposio de Recursos Hídricos del Cono Sur. Departamento General de Irrigación y Comité Permanente de los Congresos Nacionales de Agua, Mendoza, Argentina.
Ministerio de Agricultura-Comisión Nacional de Riego. 2006. Programa de organización y capacitación de organizaciones de usuarios del agua y desarrollo de organizaciones territoriales para diversas regiones del país. Resumen Ejecutivo - Informe final. Available at http://www.chileriego.cl/opensite/frm_opensite. asp?glb_cod_sistema $=20020129172812 \&$ glb_cod_ nodo=20041125172511\&glb_cod_nodo_recarga=20 070820170335\&glb_send=link (Accessed December 2007).

Ministerio de Obras Públicas - Dirección General de Aguas. 1999. Política nacional de recursos hídricos. 58 p. Ministerio de Obras Públicas, Dirección General de Aguas, Santiago, Chile.

Molle, F., J-P. Venot, and Y. Hassan. 2008. Irrigation in the Jordan Valley: Are water pricing policies overly optimistic? Agr. Water Manage. 95:427-438.

República de Chile. 2006. Código de aguas. 286 p. Editorial Jurídica de Chile. Edición Oficial aprobada por Decreto 1442 del 29 de diciembre del 2006 del Ministerio de Justicia, Santiago, Chile.

San Martín, A. 2007. Evaluación del costo de administración y gestión del agua en algunas organizaciones de usuarios en Chile. 103 p. Tesis Ingeniero Civil Agrícola. Universidad de Concepción, Facultad de Ingeniería Agrícola, Chillán, Chile. 


\title{
FECAL CONTAMINATION OF GROUNDWATER IN A SMALL RURAL DRYLAND WATERSHED IN CENTRAL CHILE
}

\author{
Mariela Valenzuela ${ }^{*}$, Bernardo Lagos ${ }^{2}$, Marcelino Claret ${ }^{3}$, María A. Mondaca ${ }^{4}$, Claudio Pérez $^{3}$, and \\ Oscar Parra1.
}

\begin{abstract}
Research on microbiological groundwater quality was conducted in Chile in a rural watershed that has almost no other water source. Forty-two wells were randomly selected and levels of indicator bacteria - total coliforms (TC), fecal coliforms (FC), and fecal streptococci (FS) - were repeatedly measured during the four seasons of 2005. The aim of this study was to characterize microbiological groundwater quality, relate indicator levels to certain watershed features and management characteristics which are likely to affect water quality. The dynamics of seasonal temporal contamination was determined with statistical analyses of indicator organism concentrations. Nonparametric tests were used to analyze relationships between bacterial indicators in well water and other variables. TC, FC, and FS were found in all samples indicating the wells had been contaminated with human and animal fecal material. The frequency distribution of microorganisms fitted a logistic distribution. The concentrations appeared to be temporal and levels varied between seasons with higher concentrations in winter. The cause of contamination could be linked to the easy access of domestic animals to the wells and to the permeable well casing material. Local precipitation runoff directly influenced the bacterial concentrations found in the wells.
\end{abstract}

Key words: biological contamination, bacteria, water quality, environmental pollution.

\section{INTRODUCTION}

Water quality is a key environmental issue involving natural watershed resources and local rural communities. The major environmental pressures have an impact on the quantity and quality of groundwater resources (Danielopol et al., 2003) which are generally perceived as being less vulnerable to contamination than surface water given the natural filtering ability of the subsurface. Although most groundwater is still thought to be free of diseasecausing microorganisms, many systems are unprotected and contamination events could eventually occur because private groundwater wells are rarely, if ever, monitored.

\footnotetext{
${ }^{1}$ Universidad de Concepción, Centro de Ciencias Ambientales EULA, Casilla 160-C, Concepción, Chile.

*Corresponding author (marvalenz@udec.cl).

${ }^{2}$ Universidad de Concepción, Facultad de Ciencias Físicas y Matemáticas, Av. Esteban Iturra s/n - Barrio Universitario, Concepción, Chile.

${ }^{3}$ Instituto de Investigaciones Agropecuarias, Centro Regional de Investigación Quilamapu, Av. Vicente Méndez 515, Chillán, Chile.

${ }^{4}$ Universidad de Concepción, Facultad de Ciencias Biológicas, Casilla 160-C, Concepción, Chile.

Received: 03 January 2008.

Accepted: 29 May 2008.
}

The risk of contaminated water for people was manifested in Lake Erie, Ohio, USA in 2004 when 1450 people became ill because of a pathogen in the well water (Fong et al., 2007). Furthermore, an estimated 750000 to 5.9 million people are sick every year as a result of contaminated groundwater in the USA (Macler and Merkle, 2000).

One of the most frequent types of contamination in rural areas is fecal pollution from different sources, most frequently livestock and inadequate on-site human waste disposal systems (Conboy and Goss, 2001; Barnes and Gordon, 2004). The size and shape of pathogenic microorganisms, their surface density properties, and biological activities set them apart from other contaminants that are transported in surface and subsurface water environments (Pachepsky et al., 2006). Concentrations of microbiological contamination indicator organisms observed in groundwater are a function of the contamination sources active at that moment (SoloGabriele et al., 2000).

Microbiological contamination is dispersed, sporadic, and influenced by a range of interacting environmental factors such as the watershed's physical characteristics, climatic conditions, and agricultural management practices. Since the largest numbers of fecal coliforms and fecal streptococci are always present in manure 
(Chadwick and Chen, 2002), then the presence of either of these microbes in a well water sample is strong evidence of fecal contamination. One of the difficulties in tackling this problem is the fact that contamination is likely to come from various possible point and nonpoint sources (Mahler et al., 2000), thus obscuring its origins. It is important to detect fecal contamination in groundwater, especially if there are no pre-consumption water treatment systems (Atherholt et al., 2003). This is the case in some rural dryland areas of Chile where farmers obtain small amounts of water from private wells and face serious water supply problems for both human consumption and agricultural activities.

Improving the quality of groundwater resources offers an important economic opportunity for the gradual improvement of the quality of life in rural dryland communities. In order to develop strategies to diminish or eliminate microbiological contamination in groundwater wells, it is first necessary to assess the variability in its concentrations, and the relative importance of different factors affecting pollution.

The variability of microorganism concentrations in Chilean groundwater and the factors affecting them are not well-known at present. As rural communities continue to rely on shallow groundwater, it is important to improve the state of knowledge about the quality of this resource. To assess the presence of fecal contamination in a rural watershed, a study was undertaken to typify the quality of microbiological groundwater, describe its seasonal pattern, and look for probable characteristics exerting an influence on the quality of groundwater.

\section{MATERIALS AND METHODS}

The small rural Estero San José (ESJ) watershed (10.8 $\mathrm{km}^{2}$ ) is located in the Bío-Bío Region, Chile (Figure 1). The catchment area is sparsely inhabited by families dedicated to traditional agriculture. The ESJ watershed is characterized by a Mediterranean climate with a long dry season leading to water shortages and a short wet season.

The watershed soils have low permeability and capacity to provide underground water. Moisture accumulation in the watershed takes place between April and June. The major runoff period of the year is from July to October when the ground is saturated and almost all the precipitation that falls in the watershed runs off. Precipitation is scarce between November and March, with practically no base flow in the watershed. Farmers obtain small amounts of water from private wells. On the average, these are $7.0 \mathrm{~m}$ deep and yield a median of 1.1 $\mathrm{L} \mathrm{min}^{-1}$. Groundwater is used as drinking water, for other domestic purposes, orchards, gardens, greenhouses, and livestock production. Agricultural production in the area
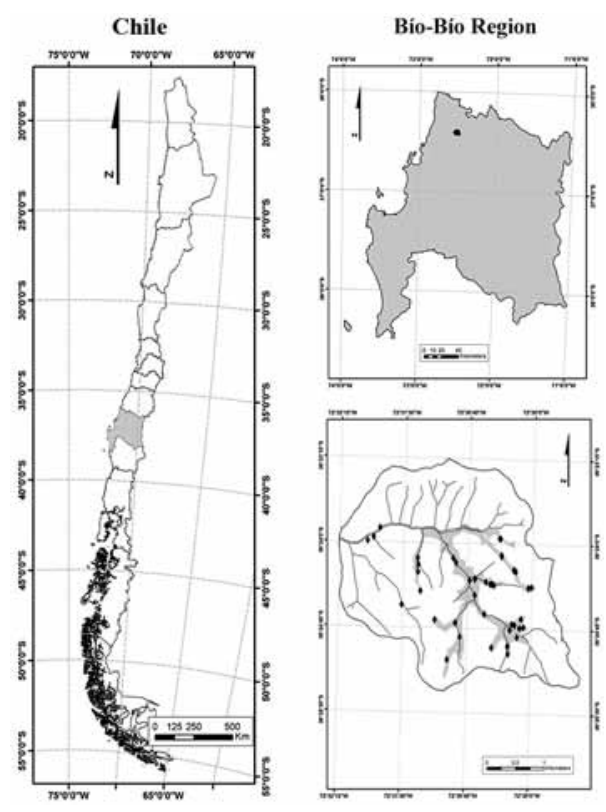

\section{Figure 1. Location of the Estero San José Watershed and sampling sites.}

is mostly wheat (Triticum aestivum L.) and lentils (Lens culinaris Medik.). The density of domestic animals is low.

A 10-month monitoring study was undertaken. Fortytwo wells were chosen with the Stratified Random Sample (Murray, 2002) and site-location data were determined with global positioning system units (Garmin 12XL, Garmin International Inc., Kansas, USA). Water pH was measured in the field with Hanna Instruments ${ }^{\circledR}$ HI9025, whereas electrical conductivity (EC) and temperature were measured with Hanna Instruments ${ }^{\circledR}$ HI9835. The sampling periods were defined in accordance with the precipitation regime and variations in the hydrologic levels in the wells. Based on these criteria, four sampling seasons were established (March, June, September, and December).

Water samples were analyzed for total coliforms (TC), fecal coliforms (FC), and fecal streptococci (FS). Although TC is widespread in the environment, it was included in order to meet the Chilean standard requirement (NCh 409. Of 70). Aseptic sample collections were taken in sterilized flasks. Samples were held at $5{ }^{\circ} \mathrm{C}$ after being collected and for no more than $6 \mathrm{~h}$ until reaching the laboratory. Results were expressed in colony forming units (CFU) per $100 \mathrm{~mL}$. TC, FC, and FS concentrations were analyzed with a membrane filtration technique following standard methods (Clesceri et al., 1998). Aliquots (100, 10 , and $1 \mathrm{~mL}$ ) of each water sample were filtered through a $0.45 \mu$ Millipore membrane filter. All samples were tested in triplicate. Results were reported as CFU 100 
$\mathrm{mL}^{-1}$. Samples that were overgrown were considered to contain > $1000 \mathrm{CFU} 100 \mathrm{~mL}^{-1}$. Colonies forming a green metallic sheen were counted as TC on m-Endo agar (Difco ${ }^{\circledR}$, Detroit, MI, USA). To count FC, filters were placed on Petri dishes containing m-FC agar (Difco ${ }^{\circledR}$, Detroit, MI, USA) which gave the selected colonies a blue color, whereas the selective FS count was carried out by incubating the filters in $\mathrm{m}$-Enterococcus agar (Difco ${ }^{\circledR}$, Detroit, MI, USA). Water sample analyses were performed in the microbiology laboratory of the Centro de Ciencias Ambientales (EULA) at the Universidad de Concepción.

Count data analyses were performed with STATISTICA ${ }^{\text {TM }}$ StatSoft 6.0. The median was used rather than the mean to analyze the microbiological data because it basically eliminates extreme values (Smith et al., 1996).

Results for TC, FC, and FS obtained in the four seasons were analyzed by looking for spatial correlations with spatial S-PLUS software using Geary's and Moran's Index (Cai and Wang, 2006). Statistical analyses were conducted to determine the relationship between bacterial concentrations and $\mathrm{pH}$, electrical conductivity, temperature, and factors expected affecting concentrations or associated with the presence of indicator bacteria. These variables were treated as binomial categorical data. To further the analysis, the variables were transformed from continuous to categorical. Data included different land use activities (prairie, gardens, orchards, bare soil) within the proximity of the monitoring well $(\mathrm{ca} .10 \mathrm{~m}$ radius); well condition (good, average, and poor); well location (highlands or lowlands); well cover (wood or cement); border height (to 15, 50, and $100 \mathrm{~cm}$ ); casing (cement or brick); slope (to 15\%, between 15\% and 60\%), latrine characteristics (location uphill or downhill from the well, casing); animal access in the vicinity of the well; type of animal (horses, pigs, sheep, poultry, cattle, dogs), and well-to-latrine distance (to $30 \mathrm{~m}$, to $80 \mathrm{~m}$ ). Parameters such as soil and geology were assumed to be constant because of the small differences detected at each sample site. Data were analyzed statistically by nonparametric Mann-Whitney rank-sum and Kolmogorov-Smirnov tests (Rohatgi, 1984) to determine significant differences in mean concentrations and indicator distribution found in well groups presenting specific characteristics. Factors were ordered dichotomously. Rainfall data were collected as an additional factor likely to exert an influence on microbiological quality. The environmental variables were selected because of their expected impact on the numbers of microorganisms detected in the samples.

\section{RESULTS AND DISCUSSION}

Groundwater indicator bacteria concentrations exceeded Chilean water quality regulations in all samples (NCh 409 Of. 70). The three indicators had a detection rate of $100 \%$, finding at least 1 CFU 100 $\mathrm{mL}^{-1}$ in all tested samples. These concentrations indicated degraded groundwater quality. The existence of both FC and FS provided strong evidence of fecal contamination (Atherholt et al., 2003). The presence of indicators in all four sampling seasons denoted frequent, if not continuous, fecal contamination in the ESJ watershed. There seemed to be a permanent source of fecal bacteria regularly entering the wells. Microbial data (Table 1) revealed marked variations throughout the year.

The most frequent indicator was TC. Seasonal variations in the microbial quality of water were evident, with peaks in winter for TC, FC, and FS. Variations in FC were less dramatic than in FS. Median concentrations of TC, FC, and FS increased in June (as compared to March), decreased in September, and increased again in December (Figure 2). This last increase can be attributed to higher demands on the wells during the later part of the year, combined with minimal water yields. Environmental persistence or growth of bacterial indicators during the summer months could confound the interpretation of baseline dynamics (Shanks et al., 2006).

The wells exhibited a high proportion of low counts and a small number of very high counts that exerted a significant influence on the median. Indeed, bacterial indicators from natural sources do not usually occur in elevated concentrations since they come from disperse sources such as waste of warm-blooded animals (Ortiz, 2004). During transport and after retention in the soil, microorganisms are affected by environmental conditions

Table 1. Median and range of indicator bacteria concentrations in the four sampled months (CFU $\left.100 \mathrm{~mL}^{-1}\right)$.

\begin{tabular}{|c|c|c|c|c|c|c|c|}
\hline \multirow{2}{*}{$\begin{array}{l}\text { Sampled } \\
\text { month }\end{array}$} & \multirow{2}{*}{$\begin{array}{c}\mathrm{N}^{\mathbf{o}} \\
\text { samples }\end{array}$} & \multicolumn{2}{|c|}{$\begin{array}{c}\text { Total } \\
\text { coliforms }\end{array}$} & \multicolumn{2}{|c|}{$\begin{array}{l}\text { Bacterial indicator } \\
\text { Fecal coliforms }\end{array}$} & \multicolumn{2}{|c|}{$\begin{array}{c}\text { Fecal } \\
\text { streptococci }\end{array}$} \\
\hline & & Median & Range & Median & Range & Median & Range \\
\hline March & 41 & 257 & $16-4.71 \times 10^{3}$ & 27 & $1-1.16 \times 10^{3}$ & 196 & $9-1.12 \times 10^{3}$ \\
\hline June & 41 & 501 & $14-5.00 \times 10^{3}$ & 190 & $1-5.80 \times 10^{3}$ & 290 & $20-1.17 \times 10^{3}$ \\
\hline September & 42 & 255 & $11-1.06 \times 10^{4}$ & 10 & $1-3.00 \times 10^{2}$ & 67 & $9-1.28 \times 10^{3}$ \\
\hline December & 39 & 440 & $22-3.60 \times 10^{3}$ & 53 & $1-1.38 \times 10^{3}$ & 120 & $5-1.10 \times 10^{3}$ \\
\hline
\end{tabular}


such as nutrient availability and predation (Pachepsky et al., 2006). Moreover, traditional monitoring and research programs quantify the microorganism concentrations in samples using standard methods. These methods are designed to target public health and do not completely measure either clumped organisms or those associated with particles, and may not fully specify organism concentrations (Borst and Selvakumar, 2003).

Indicator concentration data fit a logistic distribution, showing a parallel evolution in the distribution of FC and FS (Figures 3, 4, 5). A descriptive criterion was chosen for this distribution.

Statistical analyses showed that FC was better correlated with TC in March, June, and December, and with FS in September. In June (winter), the three indicators showed the highest correlation. FC and TC were highly correlated. Correlation analyses revealed a strong, significant, and positive correlation between TC and FC in June (Table 2). A strong relationship between two indicators may provide some evidence that both indicators originate from the same or similar contamination sources (Francy et al., 2000). Correlations between indicators, without considering the season, were very low $(r=0.35$

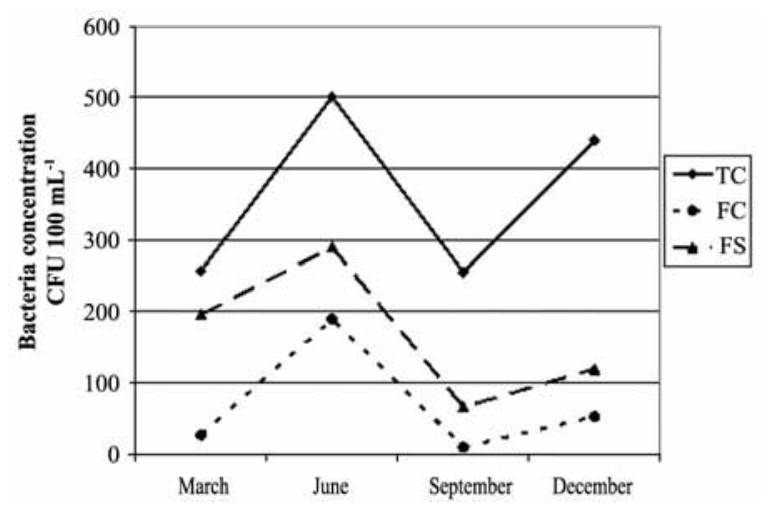

CFU: Colony Forming Units; TC: Total Coliforms; FC: Fecal Coliforms; FS: Fecal Streptococci.

Figure 2. Median concentrations of indicator bacteria.

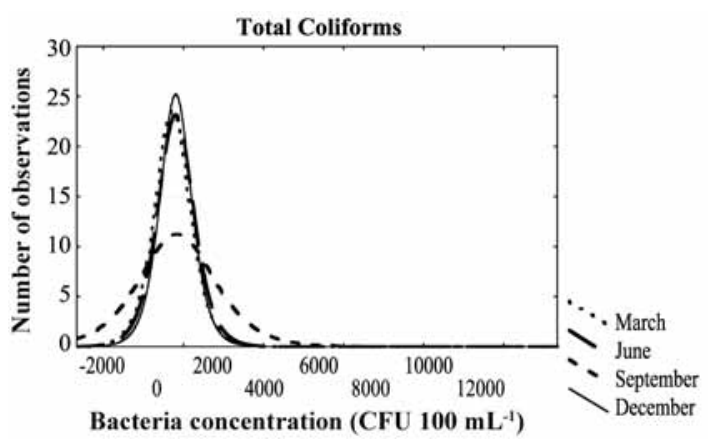

Figure 3. Logistic distribution of TC (Total Coliforms). between TC and FC, $\mathrm{r}=0.34$ between FC and FS, and $\mathrm{r}$ $=0.21$ between TC and FS, $\mathrm{p}<0.05$ ). Strong correlations between indicators were obtained only when the analyses considered the season. Analysis of the annual pattern showed almost no correlations. This confirmed the importance of carrying out seasonal analyses.

By comparing indicator medians in different seasons (Kruskal-Wallis test for comparing medians), it was possible to obtain results for $\mathrm{FC}$ (p-value $=2.95 \times$ $10^{9}$ ) which infer that seasonal medians were not equal, although FC did not change drastically with the seasons. There were differences (with a significance level of 5\%) between the medians of: March/June, March/ September, June/September, and September/December. FS had a p-value $=7.95 \times 10^{7}$. Differences had the same significance level between the medians of: March/ September, June/September, and June/December. The significant differences observed between the median concentrations of June with respect to September and December for FC and FS showed a temporal change. Median concentrations of TC did not differ significantly between seasons. Persistence of bacteria in the aquatic environment depends on various parameters, especially on the existing nutrients and temperatures (Leclerc et al., 2002). The prevalence of FS, which die off more rapidly in the environment than other bacterial indicators, shows either relatively recent contamination of a source by fecal

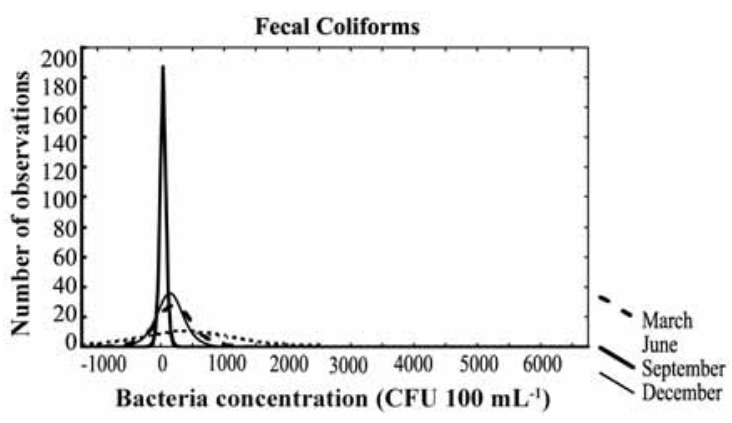

Figure 4. Logistic distribution of FC (Fecal Coliforms).

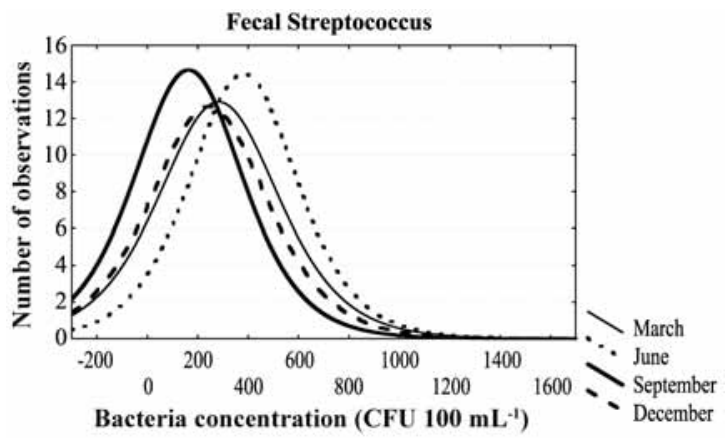

Figure 5. Logistic distribution of FS (Fecal Streptococci). 
Table 2. Correlation coefficients (r) between different indicator organism concentrations.

\begin{tabular}{|c|c|c|c|c|c|c|c|c|c|c|c|c|}
\hline \multirow[b]{3}{*}{ Organism } & \multicolumn{12}{|c|}{ Sample month } \\
\hline & \multicolumn{3}{|c|}{ March } & \multicolumn{3}{|c|}{ June } & \multicolumn{3}{|c|}{ September } & \multicolumn{3}{|c|}{ December } \\
\hline & TC & FC & FS & TC & FC & FS & TC & FC & FS & TC & FC & FS \\
\hline TC & 1 & 0.26 & 0.28 & 1 & $0.91 *$ & $0.60 *$ & 1 & 0.23 & $0.41 * *$ & 1 & $0.40^{* *}$ & -0.06 \\
\hline FC & & 1 & 0.11 & & 1 & $0.53 *$ & & 1 & 0.24 & & 1 & 0.12 \\
\hline FS & & & 1 & & & 1 & & & 1 & & & 1 \\
\hline
\end{tabular}

${ }^{*} \mathrm{p}<0.001 .{ }^{* *} \mathrm{p}<0.05$. TC: Total coliforms. FC: Fecal coliforms. FS: Fecal streptococci.

material or a very high level of contamination possibly associated with organic matter (Conboy and Goss, 2001); the latter could have been the case in September. FC was more persistent in freshwater than FS (Anderson et al., 2005). Nevertheless, in an experiment of some treatments in simulated groundwater environments by Conboy and Goss (2001), FS was able to survive for over $140 \mathrm{~d}$.

Concentrations of TC, FC, and FS were not correlated with well temperature, conductivity, and $\mathrm{pH}(\mathrm{p}<0.001)$. Rainfall measured over the sampling period was $23.6 \mathrm{~mm}$ until March, $447.7 \mathrm{~mm}$ between March and June, 302.5 $\mathrm{mm}$ between June and September, and $59.9 \mathrm{~mm}$ between September and December (Figure 6).

The highest rainfall was recorded between May and July. FC and FS median concentrations varied over time and showed a pattern similar to that of rainfall. However, FS were more affected by rainfall than FC, although the variation patterns of $\mathrm{FC}$ were highly influenced by two extreme concentrations. Correlation coefficients between indicators and rainfall showed a significant relationship with FC $(r=0.84)$ and FS $(r=0.81)$. This relationship was weak for TC $(r=0.23)$ and not coupled with other factors. The high temporal variance in the collected data means that precipitation can exert an influence by providing transport energy for the potential sources. The median demonstrated that microbial water quality changes following a rainfall runoff pattern for microbial source inputs, with a marked annual cycle (Figure 6). Results revealed a strong association between bacterial concentrations in groundwater wells and rainfall through elevated concentrations in samples taken after precipitation. It can be assumed that the higher concentrations recorded in June are partly attributable to the fact that it is the wettest month of the year. These correlations suggest that bacteria were largely associated with suspended particulate materials and transported by runoff, since some coliforms in runoff are associated with particles (George et al., 2004). Characteristics of the initial fecal material deposition site on the soil surface influence the infiltration, runoff, and retention rate of the microorganisms in the feces (Ferguson et al., 2003). Soil surrounding wells was eroded at almost all the sites, thereby preventing interaction between bacteria that could be transported by runoff and allowing them to eventually reach the well.

Moreover, no spatial correlations were found according to Geary's and Moran's Index. Neighboring wells were hydrologically independent. Spatial variability in the concentrations of TC, FC, and FS was not significant (Kolmogorov-Smirnov test, $\mathrm{p}<0.05$ ) between sampling sites in the highlands and lowlands of the watershed. Fecal contamination due to surface runoff implied that the phenomenon is highly responsive to rainfall intensity and duration, and will display a high degree of temporal variability. The fact that there is no significant difference between concentrations of indicators in highlands and lowlands suggests that local runoff produced the contamination rather than a landscape level phenomenon.

The analysis of the relationship between bacterial indicator levels and environmental characteristics presents several statistical challenges. Due to the complex nature of FC destination and transport, empirical methods such as regression models are unable to build up reliable load-concentration relationships (Bai and Lung, 2006). However, factors (Table 3) were recorded which were expected to affect concentrations or be associated with the presence of indicator bacteria since these offer preliminary insight into the causes of well contamination.

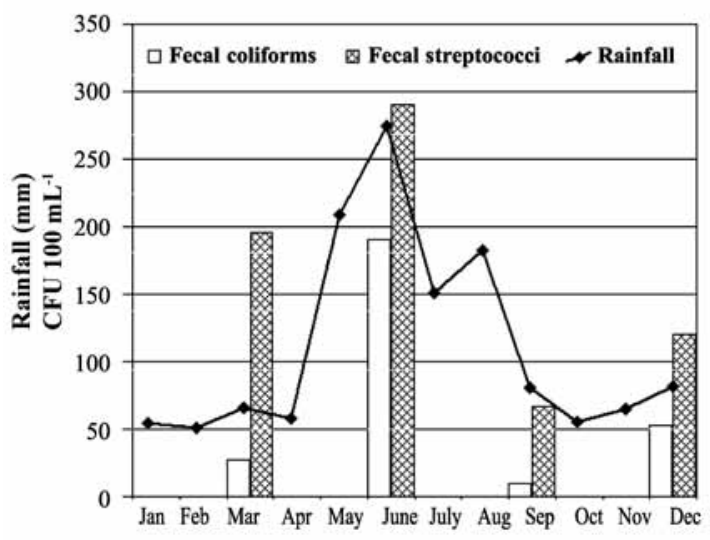

Figure 6. Rainfall and seasonal variability of indicator bacteria concentrations. 
Table 3. Landscape and management factors expected to affect concentrations or be associated with the presence of indicator bacteria.

\begin{tabular}{|c|c|c|c|c|c|c|c|c|c|c|c|}
\hline Well & $\begin{array}{l}\text { Land } \\
\text { use }\end{array}$ & Slope & AA & $\begin{array}{c}\text { Animal } \\
\text { type }\end{array}$ & $\begin{array}{c}\text { Well } \\
\text { condition }\end{array}$ & $\begin{array}{l}\text { Well } \\
\text { cap }\end{array}$ & $\begin{array}{l}\text { Well } \\
\text { cover }\end{array}$ & B h & $\mathbf{L U}$ & D & $\begin{array}{c}\mathrm{L} \\
\text { casing }\end{array}$ \\
\hline 1 & Prairie & 5 & Yes & $\mathrm{H}$ & Good & Wood & Cement & 45 & Yes & 85 & Cement \\
\hline 2 & Orchard & 15 & Yes & $\mathrm{Pi}$ & Good & Wood & Cement & 100 & Yes & 11 & Cement \\
\hline 3 & Garden & 5 & No & - & Good & Wood & Brick & 30 & No & 42 & None \\
\hline 4 & Orchard & 5 & Yes & Po & Good & Cement & Cement & 60 & No & 84 & None \\
\hline 5 & Orchard & 9 & No & - & Regular & Cement & Brick & 30 & Yes & 44 & Cement \\
\hline 6 & Prairie & 15 & Yes & S & Regular & Wood & Cement & 30 & No & 40 & None \\
\hline 7 & Prairie & 10 & Yes & S & Poor & Wood & Cement & 40 & No & 52 & None \\
\hline 8 & Bare soil & 26 & No & - & Good & Cement & Cement & 3 & Yes & 70 & None \\
\hline 9 & Orchard & 10 & Yes & Po & Regular & Cement & Cement & 70 & Yes & 28 & None \\
\hline 10 & Orchard & 18 & No & - & Regular & Wood & Cement & 75 & Yes & 83 & None \\
\hline 11 & Orchard & 40 & Yes & Po & Poor & Wood & Cement & 40 & Yes & 62 & Cement \\
\hline 12 & Orchard & 35 & Yes & Po. C & Poor & Wood & Cement & 40 & Yes & 85 & None \\
\hline 13 & Orchard & 35 & Yes & Po & Regular & Cement & Cement & 40 & Yes & 50 & None \\
\hline 14 & Orchard & 40 & Yes & Po, pi & Good & Cement & Cement & 60 & Yes & 62 & Cement \\
\hline 15 & Bare soil & 18 & No & - & Regular & Wood & Cement & 50 & Yes & 82 & None \\
\hline 16 & Prairie & 30 & Yes & Po & Poor & Wood & Brick & 18 & Yes & 120 & None \\
\hline 17 & Bare soil & 45 & Yes & Po, C & Good & Cement & Cement & 40 & No & 86 & None \\
\hline 18 & Prairie & 5 & Yes & Po, C & Good & Cement & Cement & 50 & No & 86 & None \\
\hline 19 & Prairie & 53 & Yes & Po, pi & Regular & Wood & Cement & 5 & Yes & 60 & None \\
\hline 20 & Orchard & 45 & No & - & Good & Cement & Brick & 15 & Yes & 48 & None \\
\hline 21 & Orchard & 25 & No & - & Good & Cement & Brick & 60 & Yes & 43 & None \\
\hline 22 & Bare soil & 5 & Yes & $\mathrm{H}$ & Good & Cement & Cement & 20 & Yes & 70 & None \\
\hline 23 & Orchard & 0 & No & - & Regular & Cement & Brick & 40 & No & 22 & None \\
\hline 24 & Prairie & 18 & No & - & Regular & Cement & Brick & 60 & Yes & 18 & None \\
\hline 25 & Prairie & 15 & Yes & Po, D & Good & Cement & Cement & 70 & Yes & 50 & None \\
\hline 26 & Garden & 10 & Yes & Po & Good & Cement & Cement & 40 & No & 23 & Cement \\
\hline 27 & Orchard & 23 & Yes & $\mathrm{C}$ & Good & Cement & Cement & 60 & Yes & 62 & Cement \\
\hline 28 & Orchard & 4 & Yes & Po & Regular & Wood & Brick & 80 & Yes & 79 & Cement \\
\hline 29 & Orchard & 17 & Yes & Po & Regular & Wood & Cement & 55 & Yes & 80 & Cement \\
\hline 30 & Prairie & 18 & Yes & Po, C & Poor & Wood & Cement & 10 & Yes & 91 & None \\
\hline 31 & Prairie & 40 & Yes & Po, C & Good & Wood & Cement & 50 & Yes & 133 & None \\
\hline 32 & Orchard & 22 & Yes & Po, S & Regular & Wood & Cement & 50 & Yes & 10 & Cement \\
\hline 33 & Orchard & 12 & Yes & Po & Good & Cement & Cement & 20 & Yes & 42 & None \\
\hline 34 & Bare soil & 13 & Yes & $\mathrm{S}$ & Poor & Cement & Cement & 5 & Yes & 54 & None \\
\hline 35 & Garden & 20 & No & - & Good & Wood & Cement & 50 & Yes & 26 & None \\
\hline 36 & Orchard & 15 & Yes & $\mathrm{D}$ & Good & Cement & Cement & 60 & Yes & 39 & None \\
\hline 37 & Prairie & 5 & No & - & Good & Cement & Cement & 100 & No & 10 & Cement \\
\hline 38 & Orchard & 18 & Yes & Po & Poor & Wood & Cement & 90 & Yes & 41 & None \\
\hline 39 & Prairie & 35 & No & - & Regular & Cement & Brick & 120 & No & 45 & None \\
\hline 40 & Orchard & 40 & Yes & Po, D & Poor & None & Cement & 45 & Yes & 11 & None \\
\hline 41 & Orchard & 5 & No & - & Poor & None & Cement & 12 & Yes & 63 & None \\
\hline 42 & Orchard & 15 & No & - & Regular & Wood & Cement & 30 & No & 82 & None \\
\hline
\end{tabular}

AA: animal access to the well. Bh: well border height. LU: latrine uphill from the well. D: distance between well and the closest latrine. L casing: latrine casing. Animal type: H: horses, Pi: pigs, Po: poultry, S: sheep, C: cattle, D: dogs. 
The distance between wells and latrines is highly variable, ranging from a minimum of 10 to $133 \mathrm{~m}$. Seventyfour percent of the latrines in the sampled households had brick casing. Hence, they were not sealed. On at least one of the four sampling dates, animals were observed around approximately $67 \%$ of the wells. Table 4 demonstrates that characteristics with $\mathrm{p}<0.052$ were considered to be statistically significant. Statistical analysis of the data showed that five factors are likely to influence the concentration of bacteria in groundwater: animal access close to the wells (specifically pigs and poultry); land use; bricks used for well casing; latrine-to-well distance; and a slope up to $15 \%$. Only two of these factors showed a highly significant $(p<0.01)$ association with the presence of the bacterial indicators: animal access close to the well in June and a latrine-to-well distance of $<80 \mathrm{~m}$ in December.

These results suggest that the most important factors affecting well vulnerability to bacterial contamination were those related to the well itself: construction and site management. In the month when the indicator concentrations are the highest, the factors potentially influencing these levels are animal access (specifically poultry) and well casing. Some wells have a brick casing instead of cement, which does not seal them sufficiently and allows water runoff from the surroundings to enter. Statistically, contamination levels were more closely tied to animal access in the vicinity of wells and the well casing material than to land use or distance between wells and latrines. Livestock grazing practices creates a diffuse source of fecal contamination to watersheds (Tian et al., 2002; Harter et al., 2002). Pathogens from animal feces may enter waterways by direct deposition or as a result of overland runoff containing fecal material deposited in the watershed. The FC:FS ratio as used by (Donderski and Wilk, 2002; Troussellier et al., 2004) showed that the source of indicator bacteria is mostly animal, followed by mixed sources. Considering that a great number of wells have fences to prevent animal access, wildlife cannot be disregarded as a source. Cox et al. (2005) showed that poultry fecal samples have a higher FC concentration (median $1.1 \times 10^{8} \mathrm{CFU} \mathrm{g}^{-1}$ wet wt) than those of other domestic animals (median for adult cattle $1.8 \times 10^{5} \mathrm{CFU} \mathrm{g}^{-1}$ wet wt, pigs $7.1 \times 10^{6} \mathrm{CFU} \mathrm{g}^{-1}$ wet wt, and sheep $6.6 \times 10^{5}$ CFU g ${ }^{-1}$ wet wt). This could explain the significance of poultry access to the wells as a factor affecting indicator counts. Furthermore, Wheeler et al. (2002) demonstrated that Enterococcus faecalis had a limited host range and was found in humans, dogs, and chickens.

Land use in the watershed also affected the extent of fecal contamination, but not as strongly as the other factors described above. A pattern did not emerge in spite of the fact that three different land uses were significant. Latrines appear to have little influence on the presence and level of bacterial indicators, suggesting that latrines can also be a potential source of microbial contamination in groundwater. Other factors not considered in this study may also affect bacterial concentrations in well water.

These data provide new information by relating indicator bacteria loads for certain factors at specific times of the year. The fact that the most significant indicator related to a factor was TC in March and in December, FC in June, and FS in September, suggests that fecal contamination is mostly a winter phenomenon.

Table 4. Factors with significant differences between the means of indicator bacteria concentrations.

\begin{tabular}{lllcl}
\hline Month & \multicolumn{1}{c}{ Indicator } & \multicolumn{1}{c}{ Factor } & P & \multicolumn{1}{c}{ Test } \\
\hline March & Fecal streptococcus & Land use: bare soil & 0.038 & Mann-Whitney \\
March & Total coliforms & Pig access & 0.015 & Mann-Whitney \\
June & Fecal coliforms & Animals close to well & $<0.005$ & Kolmogorov-Smirnov \\
June & Fecal coliforms & Animals close to well & 0.021 & Mann-Whitney \\
June & Fecal coliforms & Poultry access & $<0.05$ & Kolmogorov-Smirnov \\
June & Fecal coliforms & Poultry access & 0.052 & Mann-Whitney \\
September & Fecal streptococcus & Land use: orchard & 0.051 & Mann-Whitney \\
September & Fecal streptococcus & Well casing material (brick) & $<0.05$ & Kolmogorov-Smirnov \\
September & Fecal streptococcus & Well casing material (brick) & 0.041 & Mann-Whitney \\
September & Fecal streptococcus & Latrine-to-well distance $<80 \mathrm{~m}$ & 0.044 & Mann-Whitney \\
December & Fecal streptococcus & Land use: garden & 0.039 & Mann-Whitney \\
December & Fecal streptococcus & Slope $<$ 15\% & 0.041 & Mann-Whitney \\
December & Total coliforms & Well casing material (brick) & $<0.05$ & Kolmogorov-Smirnov \\
December & Total coliforms & Well casing material (brick) & 0.033 & Mann-Whitney \\
December & Total coliforms & Latrine-to-well distance $<80 \mathrm{~m}$ & $<0.05$ & Kolmogorov-Smirnov \\
December & Total coliforms & Latrine-to-well distance $<80 \mathrm{~m}$ & 0.007 & Mann-Whitney \\
\hline
\end{tabular}




\section{CONCLUSIONS}

There is widespread groundwater contamination in the ESJ watershed. The microbiological quality of the sampled wells was impaired with regard to Chilean standards.

A seasonal trend was identified. Concentrations of FC and FS varied over time and showed a pattern similar to rainfall which appeared to exert a local influence on the indicator concentrations. FS were more affected by rainfall than FC.

The lack of a significant difference between wells located uphill and downhill suggests that contamination is not a result of surface runoff from upgradient areas. Our results indicate that one cause of microbial contamination in well water is manure bacteria entering directly through local surface runoff.

There was no spatial correlation between wells, showing that there were no identified groups of wells which maintained certain concentration tendencies.

The present study shows that the analysis of microbial data in combination with basic environmental and management data can provide preliminary insight into the causes of fecal contamination in groundwater. In fact, indicator counts turned out to be significantly related to certain watershed features during specific months. Inherent well site characteristics and its surroundings, as well as rainfall are the main factors that affect groundwater quality in the ESJ watershed.

\section{ACKNOWLEDGEMENTS}

This study was funded in partnership with JICA, Japan International Cooperation Agency.

\section{RESUMEN}

Contaminación fecal en agua subterránea en una pequeña cuenca de secano rural en Chile Central. Se realizó una investigación de la calidad microbiológica de las aguas subterráneas en una cuenca rural chilena. En esta cuenca prácticamente no había otra fuente de agua disponible. En 42 pozos seleccionados al azar, se midieron niveles de bacterias indicadoras en cuatro temporadas distintas durante el año 2005. Las bacterias incluyeron coliformes totales (TC), coliformes fecales (FC) y Estreptococos fecales (FS). El objetivo fue caracterizar la calidad microbiológica del agua subterránea y relacionar los indicadores con ciertas propiedades y el manejo de la cuenca que pueden afectar la calidad del agua. La dinámica temporal de la contaminación fue determinada mediante análisis estadístico de la concentración de organismos indicadores. Las relaciones entre indicadores bacteriales presentes en el agua de los pozos y otras variables fueron analizadas con pruebas no paramétricas. En todas las muestras se detectaron TC, FC y FS, indicando que los pozos han estado contaminados con material fecal de humanos y animales. La distribución de frecuencia de los microorganismos se ajustó a una distribución logística. Las concentraciones muestran una base temporal con niveles variables entre temporadas, con una mayor concentración en invierno. La causa de la contaminación se puede asociar al fácil acceso de los animales domésticos a los pozos, y a su material de revestimiento permeable. La escorrentía local de las precipitaciones mostró tener una influencia directa sobre la concentración de los microorganismos en los pozos y en la concentración de los indicadores bacteriales encontrados en los pozos.

Palabras clave: contaminación biológica, bacteria, calidad del agua, contaminación ambiental.

\section{LITERATURE CITED}

Anderson, K.L., J.E Whitlock, and V.J. Harwood. 2005. Persistence and differential survival of fecal indicator bacteria in subtropical waters and sediments. Appl. Environ. Microbiol. 71:3041-3048.

Atherholt, T., E. Feerst, B. Hovendon, J. Kwak, and J. Rosen. 2003. Evaluation of indicators of fecal contamination in groundwater. J. Am. Water Works Assoc. 95:119-131.

Bai, S., and W-S. Lung. 2006. Three-dimensional modeling of fecal coliform in the tidal basin and Washington channel, Washington, DC. J. Environ. Sci. Health A. Tox. Hazard Subst. Environ. Eng. 41:1327-1346.

Barnes, B., and D.M. Gordon. 2004. Coliform dynamics and the implications for source tracking. Environ. Microbiol. 6:501-509.

Borst, M., and A. Selvakumar. 2003. Particle-associated microorganisms in stormwater runoff. Water Res. 37:215-223.

Cai, X., and D. Wang. 2006. Spatial autocorrelation of topographic index in catchments. J. Hydrol. 328:581591.

Chadwick, D.R., and S. Chen. 2002. Manures. p. 5882. In Haygarth, P., and S. Jarvis (eds.) Agriculture, hydrology and water quality. CABI Publishing. Institute of Grassland and Environmental Research, North Wyke, Devon, UK.

Clesceri, L.S., Greenberg, A.E., and A.D. Eaton (eds.) 1998. Standard methods for the examination of water and wastewater. 20 $0^{\text {th }}$ ed. 1325 p. American Public Health Association (APHA), Washington DC, USA. 
Conboy, M.J., and M.J. Goss. 2001. Identification of an assemblage of indicator organisms to assess timing and source of bacterial contamination in groundwater. Water Air Soil Pollut. 129:101-118.

Cox, P., M. Griffith, M. Angles, D. Deere, and C. Ferguson. 2005. Concentrations of pathogens and indicators in animal feces in the Sydney watershed. Appl. Environ. Microbiol. 71:5929-5934.

Danielopol, D.L., C. Griebler, A. Gunatilaka, and J. Notenboom. 2003. Present state and future prospects for groundwater ecosystems. Environ. Conserv. 30:104-130.

Donderski, W., and I. Wilk. 2002. The sanitary state of water in the river Vistula between Wyszogrod and Torun. Pol. J. Environ. Stud. 11:509-515.

Ferguson, C., A. Husman, N. Altavilla, D. Deere, and N. Ashbolt. 2003. Fate and transport of surface water pathogens in watersheds. Crit. Rev. Environ. Sci. Tecnol. 33:299-361.

Fong, T.-T., L.S. Mansfield, D.L. Wilson, D.J. Schwab, S.L. Molloy, and J.B. Rose. 2007. Massive microbiological groundwater contamination associated with a waterborne outbreak in Lake Erie, South Bass Island, Ohio. Environ. Health Persp. 115:856-863.

Francy, D.S., D.R. Helsel, and R.A. Nally. 2000. Occurrence and distribution of microbiological indicators in groundwater and stream water. Water Environ. Res. 72:152-161.

George, I., A. Anzil, and P. Servais. 2004. Quantification of fecal coliform inputs to aquatic systems through soil leaching. Water Res. 38:611-618.

Harter, T., H. Davis, M.C. Mathews, and R.D. Meyer. 2002. Shallow groundwater quality on dairy farms with irrigated forage crops. J. Contam. Hydrol. 55:287-315.

Leclerc, H., L. Schwartzbrod, and E. Dei-Cas. 2002. Microbial agents associated with waterborne diseases. Crit. Rev. Microbiol. 28:371-409.

Macler, B.A., and J.C. Merkle. 2000. Current knowledge on groundwater microbial pathogens and their control. Hydrogeol. J. 8:29-40.

Mahler, B.J., J.-C. Personné, G.F. Lods, and C. Drogue. 2000. Transport of free and particulate- associated bacteria in karst. J. Hydrol. 238:179-193.
Murray, C.J. 2002. Sampling and data analysis for environmental microbiology. p. 166-178. In Hurst, C.J., R.L. Crawford, G.R. Knudsen, M.J. McInerney, and L.D. Stetzenbach (eds.) Manual of environmental microbiology. $2^{\text {nd }}$ ed. ASM Press, Washington D.C., USA.

Ortiz, R. 2004. Ground-water quality of alluvial and sedimentary-rock aquifers in the vicinity of Fairplay and Alma, Park County, Colorado, September-October 2002. USGS Fact Sheet 2004-3065. US Geological Survey, Branch of Information Services, Denver, Colorado, USA.

Pachepsky, Y.A., A.M. Sadeghi, S.A. Bradford, D.R. Shelton, A.K. Guber, and T. Dao. 2006. Transport and fate of manure -borne pathogens: modeling perspective. Agr. Water Manage. 86:81-92.

Rohatgi, V. 1984. Statistical inference. 940 p. John Wiley \& Sons, New York, USA.

Shanks, O., C. Nietch, M. Simonich, M. Younger, D. Reynolds, and K. Field. 2006. Basin-wide analysis of the dynamics of fecal contamination and fecal source identification in Tillamook Bay, Oregon. Appl. Environ. Microbiol. 72:5537-5546.

Smith, S V., R.M. Chambers, and J.T. Hollibaugh. 1996. Dissolved and particulate nutrient transport through a coastal watershed-estuary system. J. Hydrol. 176:181203.

Solo-Gabriele, H.M., M.A. Wolfert, T.R. Desmarais, and C.J. Palmer. 2000. Sources of Escherichia coli in a coastal subtropical environment. Appl. Environ. Microbiol. 66:230-237.

Tian, Y.Q., P. Gong, J.D. Radke, and J. Scarborough. 2002. Spatial and temporal modeling of microbial contaminants on grazing farmlands. J. Environ. Qual. 31:860-869.

Troussellier, M., P. Got, M. Bouvy, M. M'Boup, R. Arfi, F. Lebihan, et al. 2004. Water quality and health status of the Senegal River estuary. Mar. Pollut. Bull. 48:852862.

Wheeler, A.L., P.G. Hartel, D.G. Godfrey, J.L. Hill, and W.I. Segars. 2002. Potential of Enterococcus faecalis as a human fecal indicator for microbial source tracking. J. Environ. Qual. 31:1286-1293. 


\title{
PHOSPHATE FERTILIZATION CAN INCREASE YIELD OF PRODUCTIVE GRASS PEA (Lathyrus sativus L.) CROPS IN P-RETENTIVE SOILS
}

\author{
Adolfo Montenegro ${ }^{1^{*}}$, and Mario Mera ${ }^{1}$
}

\begin{abstract}
The effect of P fertilization on grass pea (Lathyrus sativus L.) yield and yield components was evaluated on soils with low P availability and high P retention capacity in small-scale farms of the Araucanía Region in southern Chile. Trials were conducted during 2000-2001, 2001-2002, and 2002-2003, in six sites; three sites in Lumaco and three in the Selva Oscura area. Six rates of $\mathrm{P}\left(0,21.8,43.6,65.4,87.2\right.$, and $\left.109.0 \mathrm{~kg} \mathrm{ha}^{-1}\right)$ were evaluated in a randomized complete block design with four replicates. Grass pea cv. Luanco-INIA was sown at 47 seeds $\mathrm{m}^{-2}$. Mean grain yield for all trials was $2456 \mathrm{~kg} \mathrm{ha}^{-1}$. Phosphate fertilization increased grass pea grain yield in both areas during 2000 and 2001. There was no significant effect in 2002. The 2002 cropping season had an unusually high spring-summer rainfall, which may have enhanced the P mineralization rate from organic soil fraction, and thus $\mathrm{P}$ availability. According to this study, grass pea crops in soils with $<10 \mathrm{mg} \mathrm{kg}^{-1}$ of available P-Olsen should respond to $\mathrm{P}$ fertilization.
\end{abstract}

Key words: grass pea, Lathyrus, phosphorus, neglected crops, cool-season legumes.

\section{INTRODUCTION}

Grass pea is a grain legume crop used for human and animal consumption since ancient times (Hanbury et al., 2000). The presence of $\beta$-N-oxalyl-L- $\alpha, \beta-$ diaminopropionic acid ( $\beta$-ODAP) in grass pea seeds is thought to increase vulnerability to neurolathyrism, a neurodegenerative disease (Lambein et al., 2007). As a result, lowODAP lines (Campbell et al., 1994) and cultivars (Siddique et al., 2006) have been found that may enhance interest in this protein crop. The potential of grass pea for animal feed also depends on the achievement of yields that make it competitive with other protein-rich ingredients.

Grass pea is grown on a wide range of soils, including those with low fertility and poor structure (Siddique et al., 1996). In southern Chile, grass pea is cultivated by small farmers with limited resources, on typically eroded soils as a result of poor management. The Araucanía Region $\left(37^{\circ} 30^{\prime}-39^{\circ} 30^{\prime} \mathrm{S}\right)$ has a particularly high number of such small farmers and its soils are characterized by low levels of available P-Olsen (Montenegro, 1991) though relatively high grain yields are often achieved. Hence, $\mathrm{P}$ fertilization is a determining factor in the yield of most crops.

Information on grass pea response to $\mathrm{P}$ fertilization is very scarce. Its effect on grain yield and yield

${ }^{1}$ Instituto de Investigaciones Agropecuarias, Centro Regional de Investigación Carillanca, Casilla 58-D, Temuco, Chile. *Corresponding author (amontene@inia.cl).

Received: 11 January 2008.

Accepted: 06 June 2008. components is largely unknown, particularly in soils with high $\mathrm{P}$ retention capacity. The comprehensive review by Campbell (1997) does not refer to P fertilization, but emphasizes that grass pea is considered a hardy crop requiring low or zero inputs. However, Sarkar et al. (2003) found that applying P increased grass pea grain yield grown in an Entisol of India with $\mathrm{pH} 7.5$, $0.53 \%$ organic carbon, and $26 \mathrm{~kg} \mathrm{ha}^{-1}$ of $\mathrm{P}_{2} \mathrm{O}_{5}$. In Chile, a clear effect of up to $65.4 \mathrm{~kg} \mathrm{ha}^{-1} \mathrm{P}$ on grass pea grain yield was reported by Ellena (1983) in an Andisol of Valdivia. Later, Montenegro et al. (2001) explained in a preliminary report that $\mathrm{P}$ fertilization was associated to higher grass pea yields in Araucanía soils with high P retention capacity. Krarup (2002) did not find any grass pea response to $\mathrm{P}$ fertilization in a soil of the Valdivia series belonging to the medial, mesic of the Duric Hapludands family (CIREN, 2003) with P-Olsen availability of $12 \mathrm{mg} \mathrm{kg}^{-1}$ or greater.

Araucanía Region soils have high levels of $\mathrm{P}$ retention, generally above $70 \%$ (Sadzawka et al., 1999) reaching levels as high as $95 \%$ in areas such as Victoria. Phosphorus retention of $70-99 \%$ has been reported for the A soil horizon in Andisols of southern Chile (Pino et al., 1998; Besoaín and Sadzawka, 1999). A wide range of farmers was surveyed in the Araucanía Region indicating that $90 \%$ of soils have available P-Olsen $<15 \mathrm{mg} \mathrm{kg}^{-1}$ (Sadzawka et al., 1999). Moreover, 60\% of such soils have P-Olsen $<10 \mathrm{mg} \mathrm{kg}^{-1}$ which is considered a critical level for most crops. This level is frequent in small farms, with a mean of $7.5 \mathrm{mg} \mathrm{kg}^{-1}$ for grass pea producers in 
Lumaco (A. Montenegro, unpublished data, 2000), one of the areas of the Araucanía Region where the reported experiments were conducted.

Phosphorus is generally absorbed by crop plants to a moderate extent compared to other macronutrients. However, in P-retentive soils such as those in southern Chile, $\mathrm{P}$ fertilizers should be applied at high rates, for example, up to $87 \mathrm{~kg} \mathrm{ha}^{-1} \mathrm{P}$ for wheat (Montenegro et al., 1999a) and oilseed rape (Montenegro et al., 1999b).They should be localized in the furrow to increase efficiency. Consequently, it is important to gather information on the magnitude of yield response of grass pea to $P$ fertilization in soils where its availability is limited.

\section{MATERIALS AND METHODS}

The study was conducted under dryland conditions during three cropping seasons (2000-2001, 2001-2002, and 2002-2003 referred hereafter as 2000, 2001, and 2002) in

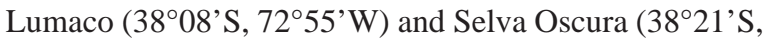
$72^{\circ} 11^{\prime} \mathrm{W}$ ), Araucanía Region, located about $150 \mathrm{~km}$ NW and $60 \mathrm{~km} \mathrm{NE}$ of Temuco, respectively. Experiments in Lumaco were conducted on a silty clay loam Inceptisols, Lumaco Series, belonging to the fine, mixed, termic, mesic of the Fluventic Dystrudepts family (CIREN, 2002). Experiments in Selva Oscura were conducted on a silty clay loam Andisols, Victoria Series, belonging to the medial, mesic of the Typic Durudands family (CIREN, 2002). Methodology for chemical determination was in accordance with Sadzawka et al. (2006). Specific sites within Lumaco and Selva Oscura were different each year.

The chemical characterization of soils $(0-20 \mathrm{~cm}$ depth) is shown in Table 1. Available P-Olsen in Lumaco soils was low in all seasons. In Selva Oscura, available P-Olsen was considered low to medium in 2000, and low in 2001 as well as 2002. Traditional crops, like wheat (Triticum aestivum L.) and oilseed rape (Brassica napus L.), for which more agronomic information is available, are expected to clearly respond to $\mathrm{P}$ fertilization in soils at these P-Olsen levels. In Lumaco, exchangeable $\mathrm{K}$ was low in 2000 and 2002, medium in 2001, and extractable S was low, whereas Al saturation was low in 2000 and 2001, but high in 2002. In Selva Oscura, soils had relatively high exchangeable $\mathrm{K}$, low extractable $\mathrm{S}$, and medium to high Al saturation.

Luanco-INIA, a large-seeded grass pea cultivar (Mera et al., 2003), was sown at 47 seeds $\mathrm{m}^{-2}$. Seeds were treated with carboxin + thiram, fipronil, and inoculated just prior to sowing with a cocktail of Rhizobium strains isolated from grass pea nodules provided by the Universidad de Concepción, Chillán, Chile. Sowing dates in Lumaco were 17 May 2000, 16 May 2001, and 7 May 2002. Sowing dates in Selva Oscura were 11 August 2000, 7 August 2001, and 3 September 2002. A randomized complete block design was used with four replicates, except in Lumaco in 2000 and 2001 where only three replicates were carried out. Plots had six rows, $4 \mathrm{~m}$ long and spaced

Table 1. Chemical characterization of soils (0-20 cm depth) from three different sites in two areas of southern Chile where experiments of $\mathbf{P}$ fertilization in grass pea were conducted during 3 years.

\begin{tabular}{|c|c|c|c|c|c|c|}
\hline \multirow{2}{*}{$\begin{array}{l}\text { Chemical parameters } \\
\text { and its unit }\end{array}$} & \multicolumn{3}{|c|}{ Lumaco } & \multicolumn{3}{|c|}{ Selva Oscura } \\
\hline & 2000 & 2001 & 2002 & 2000 & 2001 & 2002 \\
\hline P-Olsen , mg kg-1 & 9 & 5 & 5 & 11 & 6 & 4 \\
\hline Organic C, \% & 2.9 & 2.3 & 3.5 & 7.0 & 6.4 & 4.1 \\
\hline pH (water) & 5.8 & 5.8 & 5.2 & 5.5 & 5.8 & 5.6 \\
\hline Exchangeable Ca, cmol kg-1 & 4.9 & 3.35 & 1.97 & 4.9 & 5.18 & 9.05 \\
\hline Exchangeable $\mathrm{Mg}, \mathrm{cmol} \mathrm{kg}^{-1}$ & 1.04 & 1.3 & 0.76 & 1.45 & 0.8 & 2.16 \\
\hline Exchangeable Na, cmol kg-1 & 0.26 & 0.08 & 0.15 & 0.11 & 0.07 & 0.13 \\
\hline Exchangeable K, cmol kg-1 & 0.07 & 0.52 & 0.13 & 0.88 & 0.96 & 0.38 \\
\hline Sum of bases, cmol kg-1 & 6.3 & 5.25 & 3.01 & 7.38 & 7.01 & 11.72 \\
\hline Exchangeable Al, cmol kg-1 & 0.09 & 0.07 & 1.24 & 0.79 & 0.28 & 1.2 \\
\hline Effective CEC, cmol kg-1 & 6.4 & 5.32 & 4.25 & 8.17 & 7.29 & 12.92 \\
\hline $\mathrm{Al}$ saturation, \% & 1.4 & 1.3 & 29.2 & 9.7 & 3.8 & 9.3 \\
\hline Extractable S, mg kg-1 & 2.4 & 6.5 & - & 4.5 & 1.3 & - \\
\hline Available Zn, mg kg-1 & 0.3 & 0.1 & - & 1.5 & 0.1 & - \\
\hline Available B, mg kg-1 & 0.4 & 0.2 & - & 0.5 & 0.2 & - \\
\hline Available Cu, mg kg-1 & 3 & 1.4 & & 2.5 & 0.6 & - \\
\hline
\end{tabular}


$35 \mathrm{~cm}$ apart. Treatments were 0, 21.8, 43.6, 65.4, 87.2, and $109.0 \mathrm{~kg} \mathrm{ha}^{-1} \mathrm{P}$, as banded superphosphate below the seed $\left(46 \% \mathrm{P}_{2} \mathrm{O}_{5}\right)$. Base fertilization was $83 \mathrm{~kg} \mathrm{ha}^{-1} \mathrm{~K}$ and $36 \mathrm{~kg} \mathrm{ha}^{-1} \mathrm{~S}$ as broadcast $\mathrm{K}_{2} \mathrm{SO}_{4}$ in all experiments and for all $\mathrm{P}$ treatments. In 2002, Al soil saturation recommended a liming treatment, so 3.5 and $3.0 \mathrm{t} \mathrm{ha}^{-1} \mathrm{CaCO}_{3}$ with an agronomic value of $92.44 \%$ was applied in Lumaco and Selva Oscura, respectively.

Aboveground biomass samples were taken in Lumaco during grass pea flowering to estimate nutrient contents only in year 2000. Grain was harvested 17 January 2001, 2 January 2002, and 16 January 2003 in Lumaco, and 26 January 2001, 21 January 2002, and 25 February 2003 in Selva Oscura. Nutrient content in biomass and grain was estimated at both locations only in 2000. Nitrogen content in biomass and grain was determined by digestion with sulphuric acid and Kjeldahl. Phosphorus content in aboveground biomass and grain was determined by calcination, digestion with $\mathrm{HCl}$, and colorimetry by vanadate. Potassium, $\mathrm{Ca}, \mathrm{Mg}$, $\mathrm{Zn}$, and $\mathrm{Cu}$ in aboveground biomass and grain were determined by calcination, digestion with $\mathrm{HCl}$, atomic absorption, and emission spectrophotometry. Boron in the aboveground biomass and the grain was determined by calcination, digestion with $\mathrm{HCl}$, and colorimetry with azomethine-H (Sadzawka et al., 2007). Samples of aboveground biomass were taken in Lumaco and Selva Oscura in 2001 during flowering in order to estimate aboveground dry biomass per hectare. Grain yield was estimated using $3.5 \mathrm{~m}$ of the four central rows at $14 \%$ moisture. Yield components were estimated from a row random sample of $25 \mathrm{~cm}$. Nutrient content of grains from both areas was determined in 2000. Analysis of variance and regression were performed with SAS (SAS Institute, 1992).

\section{RESULTS AND DISCUSSION}

In 2000 and 2001, P fertilization increased grain yields in both areas, in agreement with previous findings (Ellena, 1983). However, no significant effect was found at any site in 2002 (Tables 2 and 3).

Grain yield mean was considerably higher in Lumaco (2908 kg ha' ${ }^{-1}$ ) than Selva Oscura (1268 kg ha-1) in 2000. The higher level of Al saturation in Selva Oscura (Table 1) may have been detrimental to grain yield. Furthermore, soil structure in Selva Oscura was altered by extremely high rainfall in June 2000 (Figure 1), and a superficial soil crust resulted from the impact of raindrops (Casanova et al., 2006), probably affecting root development. In 2000, the effect of increasing $\mathrm{P}$ fertilization rates on grain yield fitted a quadratic model response with Equation [1] for Lumaco and Equation [2] for Selva Oscura:

$y=2335.39+18.2995 \mathrm{P}-0.097557 \mathrm{P}^{2}$, with $\mathrm{R}^{2}=0.60$

$y=875.14+8.300078 \mathrm{P}-0.01356 \mathrm{P}^{2}$, with $\mathrm{R}^{2}=0.77$

where $y$ is the grain yield $\left(\mathrm{kg} \mathrm{ha}^{-1}\right), \mathrm{P}$ is the amount of $\mathrm{P}$ applied $\left(\mathrm{kg} \mathrm{Pha}^{-1}\right)$, and $\mathrm{R}^{2}$ is the coefficient of determination for the equation.

Contrary to 2000, there were higher mean yields in 2001 in Selva Oscura (2465 kg ha-1) than in Lumaco $\left(1687 \mathrm{~kg} \mathrm{ha}^{-1}\right)$. Water availability in 2001 was less than

Table 2. Effect of $\mathbf{P}$ fertilization on stand, grain yield, and grain weight of grass pea cv. Luanco-INIA in Lumaco, southern Chile, during 3 years.

\begin{tabular}{|c|c|c|c|c|c|c|c|c|c|}
\hline \multirow[b]{2}{*}{$\begin{array}{l}\text { Applied } \\
\text { phosphorus }\end{array}$} & \multicolumn{3}{|c|}{2000} & \multicolumn{3}{|c|}{2001} & \multicolumn{3}{|c|}{2002} \\
\hline & $\begin{array}{l}\text { Stand } \\
\text { plants }\end{array}$ & $\begin{array}{l}\text { Grain } \\
\text { yield }\end{array}$ & $\begin{array}{l}\text { Grain } \\
\text { weight }\end{array}$ & $\begin{array}{l}\text { Stand } \\
\text { plants }\end{array}$ & $\begin{array}{l}\text { Grain } \\
\text { yield }\end{array}$ & $\begin{array}{l}\text { Grain } \\
\text { weight }\end{array}$ & $\begin{array}{l}\text { Stand } \\
\text { plants }\end{array}$ & $\begin{array}{l}\text { Grain } \\
\text { yield }\end{array}$ & $\begin{array}{l}\text { Grain } \\
\text { weight }\end{array}$ \\
\hline $\mathrm{kg} \mathrm{ha}^{-1} \mathrm{P}$ & plant $\mathrm{m}^{-2}$ & $\mathrm{~kg} \mathrm{ha}^{-1}$ & $\mathrm{mg}$ & plant $\mathrm{m}^{-2}$ & $\mathrm{~kg} \mathrm{ha}^{-1}$ & $\mathrm{mg}$ & plant $\mathrm{m}^{-2}$ & $\mathrm{~kg} \mathrm{ha}^{-1}$ & $\mathrm{mg}$ \\
\hline 0.0 & 41.4 & 2359 & 327 & 32.8 & 1036 & 286 & 40.2 & 3248 & 285 \\
\hline 21.8 & 40.6 & 2695 & 333 & 33.1 & 1553 & 284 & 38.2 & 3126 & 305 \\
\hline 43.6 & 40.8 & 2841 & 340 & 29.2 & 1553 & 279 & 38.6 & 3598 & 288 \\
\hline 65.4 & 39.7 & 3155 & 341 & 32.0 & 1700 & 281 & 40.8 & 3482 & 283 \\
\hline 87.2 & 38.8 & 3282 & 346 & 30.4 & 1945 & 294 & 38.6 & 3425 & 297 \\
\hline 109.0 & 39.5 & 3114 & 330 & 35.0 & 2334 & 296 & 34.5 & 3014 & 292 \\
\hline Mean & 40.1 & 2908 & 336 & 32.1 & 1687 & 287 & 38.5 & 3316 & 292 \\
\hline CV, \% & 4.7 & 7.8 & 2.7 & 12.3 & 16.4 & 6.3 & 12.40 & 14.0 & 6.1 \\
\hline $\mathrm{F}$ & 0.79 & 6.91 & 2.04 & 1.10 & 9.83 & 0.59 & 0.86 & 0.93 & 0.88 \\
\hline$P>F$ & ns & 0.01 & ns & ns & $<0.01$ & ns & ns & ns & ns \\
\hline
\end{tabular}

Grain weight is a mean value calculated from a random sample of 500 grains. ns = non significant.

$\mathrm{CV}$ : coefficient of variation. F: ratio of treatments mean square and experimental error mean square. 
Table 3. Effect of $\mathbf{P}$ fertilization on stand, grain yield, and grain weight of grass pea cv. Luanco-INIA in Selva Oscura, southern Chile, during 3 years.

\begin{tabular}{|c|c|c|c|c|c|c|c|c|c|}
\hline \multirow[b]{2}{*}{$\begin{array}{l}\text { Applied } \\
\text { phosphorus }\end{array}$} & \multicolumn{3}{|c|}{2000} & \multicolumn{3}{|c|}{2001} & \multicolumn{3}{|c|}{2002} \\
\hline & $\begin{array}{l}\text { Stand } \\
\text { plants }\end{array}$ & $\begin{array}{l}\text { Grain } \\
\text { yield }\end{array}$ & $\begin{array}{l}\text { grain } \\
\text { weight }\end{array}$ & $\begin{array}{l}\text { Stand } \\
\text { plants }\end{array}$ & $\begin{array}{l}\text { Grain } \\
\text { yield }\end{array}$ & $\begin{array}{l}\text { grain } \\
\text { weight }\end{array}$ & $\begin{array}{l}\text { Stand } \\
\text { plants }\end{array}$ & $\begin{array}{l}\text { Grain } \\
\text { yield }\end{array}$ & $\begin{array}{c}\text { grain } \\
\text { weight }\end{array}$ \\
\hline $\mathrm{kg} \mathrm{ha}^{-1} \mathrm{P}$ & plant $\mathrm{m}^{-2}$ & $\mathrm{~kg} \mathrm{ha}^{-1}$ & $\mathrm{mg}$ & plant $\mathrm{m}^{-2}$ & $\mathrm{~kg} \mathrm{ha}^{-1}$ & $\mathrm{mg}$ & plant $\mathrm{m}^{-2}$ & $\mathrm{~kg} \mathrm{ha}^{-1}$ & mg \\
\hline 0.0 & 38.9 & 870 & 354 & 44.1 & 2143 & 298 & 45.7 & 2796 & 368 \\
\hline 21.8 & 40.9 & 1065 & 365 & 39.2 & 2126 & 292 & 45.6 & 2952 & 357 \\
\hline 43.6 & 37.7 & 1203 & 370 & 44.9 & 2386 & 297 & 42.3 & 3490 & 353 \\
\hline 65.4 & 35.5 & 1342 & 365 & 35.9 & 2535 & 309 & 40.7 & 2833 & 359 \\
\hline 87.2 & 38.2 & 1521 & 356 & 45.3 & 2966 & 299 & 43.6 & 3070 & 369 \\
\hline 109.0 & 39.8 & 1610 & 370 & 43.6 & 2634 & 307 & 45.7 & 3584 & 371 \\
\hline Mean & 38.5 & 1268 & 363 & 42.2 & 2465 & 300 & 43.9 & 3095 & 363 \\
\hline CV, \% & 5.1 & 11.9 & 2.8 & 11.0 & 9.0 & 3.2 & 11.1 & 13.9 & 5.6 \\
\hline $\mathrm{F}$ & 3.61 & 13.68 & 1.8 & 2.65 & 8.26 & 1.69 & 0.74 & 1.98 & 0.55 \\
\hline$P>F$ & 0.05 & 0.01 & ns & ns & $<0.01$ & ns & ns & ns & $\mathrm{ns}$ \\
\hline
\end{tabular}

Grain weight is a mean value calculated from a random sample of 500 grains. ns $=$ non significant.

$\mathrm{CV}$ : coefficient of variation. F: ratio of treatments mean square and experimental error mean square.

in 2000, particularly in Lumaco, which probably caused the lower mean grain yield there in 2001, as compared with 2000 and 2002 (Table 2). The effect of increasing P fertilization rates on grain yield in Lumaco in 2001 fitted a linear model response and a quadratic model response for Selva Oscura with Equations [3] and [4], respectively:

$y=1129.10476+10.23309 \mathrm{P}$, with $\mathrm{R}^{2}=0.63$

$y=1890.05955+15.48615 \mathrm{P}-0.06904 \mathrm{P}^{2}$,

with $\mathrm{R}^{2}=0.54$

where $y, \mathrm{P}$, and $\mathrm{R}^{2}$ are described Equations [1] and [2].

There was no significant effect of $\mathrm{P}$ fertilization on grain yield at any site. Unlike previous years, liming was applied in 2002 due to the high percentage of $\mathrm{Al}$ saturation found at both sites (Table 1). As a result, plant growth at both sites was more vigorous during 2002 than in previous years. Although not the aim of the present experiment, development of the grass pea plant was found to be severely limited by medium to high $\mathrm{Al}$ saturation and its associated high soil acidity. As a consequence, corrective liming was very effective. In addition, rainfall in October-December 2002 was unusually high (Figure 1) and soil moisture was still abundant during the favorable temperatures of late spring. These conditions may have enhanced $\mathrm{P}$ mineralization from organic soil fraction. Thus, the lack of response to added P during 2002 may have resulted from more available $\mathrm{P}$ in the soil. This would explain the very high grain yields (3248 and $2796 \mathrm{~kg} \mathrm{ha}^{-1}$ in Lumaco and Selva Oscura, respectively) achieved by controls where $\mathrm{P}$ was not applied.

Phosphate fertilization did not have a significant effect on grain weight in any site or year despite the relatively
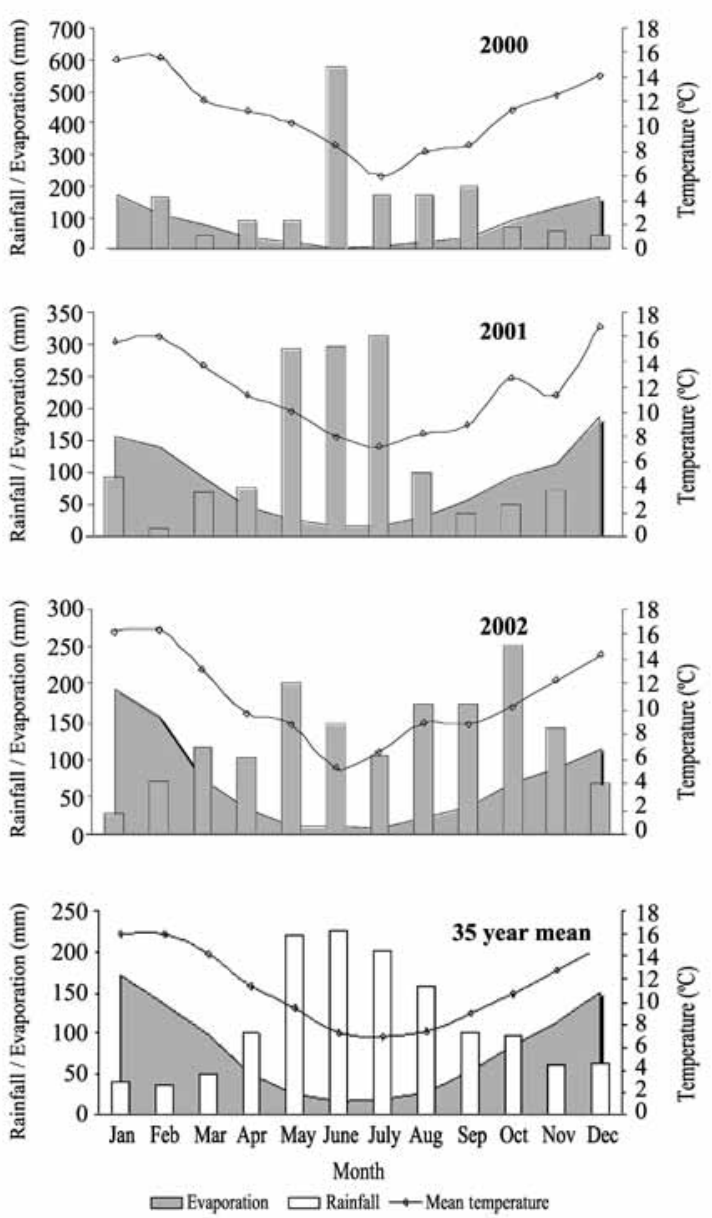

Figure 1. Monthly rainfall, evaporation, and mean temperature during 2000, 2001, 2002, and 35-yr mean at Carillanca, La Araucanía Region, southern Chile. 
Table 4. Nutrient content of aboveground biomass of grass pea cv. Luanco-INIA during flowering stage in Lumaco, southern Chile in $\mathbf{2 0 0 0 - 2 0 0 1}$ for six rates of $P$ fertilization.

\begin{tabular}{|c|c|c|c|c|c|c|c|c|c|}
\hline Applied phosphorus & $\mathbf{N}$ & $\mathbf{P}$ & $\mathbf{K}$ & $\mathrm{Ca}$ & Mg & Zn & Mn & $\mathrm{Cu}$ & B \\
\hline \multicolumn{10}{|l|}{$\mathrm{kg} \mathrm{ha}^{-1} \mathrm{P}$} \\
\hline 0.0 & 2.18 & 0.13 & 0.54 & 0.51 & 0.27 & 13.0 & 67.0 & 5.0 & 31.0 \\
\hline 21.8 & 1.83 & 0.10 & 0.51 & 0.48 & 0.26 & 12.0 & 65.0 & 5.0 & 32.0 \\
\hline 43.6 & 2.31 & 0.09 & 0.53 & 0.62 & 0.25 & 12.0 & 83.0 & 4.0 & 34.0 \\
\hline 65.4 & 2.17 & 0.09 & 0.51 & 0.53 & 0.25 & 12.0 & 74.0 & 4.0 & 31.0 \\
\hline 87.2 & 1.98 & 0.10 & 0.46 & 0.58 & 0.30 & 14.0 & 73.0 & 4.0 & 35.0 \\
\hline 109.0 & 2.18 & 0.11 & 0.47 & 0.56 & 0.27 & 13.0 & 67.0 & 4.0 & 32.0 \\
\hline Mean & 2.11 & 0.10 & 0.50 & 0.55 & 0.27 & 12.7 & 71.5 & 4.3 & 32.5 \\
\hline
\end{tabular}

Data are from a compound sample of three replicates.

Table 5. Nutrient accumulation by aboveground biomass of grass pea cv. Luanco-INIA up to flowering stage in Lumaco, southern Chile in 2000-2001 for six rates of $P$ fertilization.

\begin{tabular}{|c|c|c|c|c|c|c|c|c|c|}
\hline Applied phosphorus & $\mathbf{N}$ & $\mathbf{P}$ & $\mathbf{K}$ & Ca & Mg & Zn & Mn & $\mathrm{Cu}$ & B \\
\hline $\mathrm{kg} \mathrm{ha}^{-1} \mathrm{P}$ & & & $\mathrm{m}^{-2}$ & & 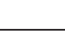 & $\nu_{2}$ & $-\mathrm{m}$ & & \\
\hline 0.0 & 14.9 & 0.89 & 3.7 & 3.5 & 1.8 & 8.9 & 45.6 & 3.4 & 21.1 \\
\hline 21.8 & 17.0 & 0.93 & 4.7 & 4.5 & 2.4 & 11.1 & 60.3 & 4.6 & 29.7 \\
\hline 43.6 & 22.7 & 0.88 & 5.2 & 6.1 & 2.5 & 11.8 & 81.4 & 3.9 & 33.4 \\
\hline 65.4 & 20.3 & 0.84 & 4.8 & 5.0 & 2.3 & 11.2 & 69.3 & 3.7 & 29.0 \\
\hline 87.2 & 25.6 & 1.30 & 6.0 & 7.5 & 3.9 & 18.1 & 94.5 & 5.2 & 45.3 \\
\hline 109.0 & 23.5 & 1.20 & 5.1 & 6.0 & 2.9 & 14.0 & 72.3 & 4.3 & 34.5 \\
\hline Mean & 20.7 & 1.00 & 4.9 & 5.4 & 2.6 & 12.5 & 70.6 & 4.2 & 32.2 \\
\hline
\end{tabular}

Nutrient accumulation was calculated by multiplying nutrient content by aboveground biomass.

low coefficients of variation for this trait. The 3-yr mean grain weight was higher in Selva Oscura (342 mg) than in Lumaco (305 mg), due to the relatively higher water availability during the pod filling stage in Selva Oscura. Variations in grain yield were not related to mean grain weight nor associated to the number of grains per pod, which had a mean of $\sim 1.6$. The number of pods per plant was the yield component that largely explained variations in grain yield. In 2000, plots that yielded 900-1600 kg ha $^{-1}$ had 6-12 pods per plant, whereas those yielding 2300$3300 \mathrm{~kg} \mathrm{ha}^{-1}$ had 13-24 pods per plant (data not shown). This noticeable difference was observed in plots with similar stands of 38-40 plants $\mathrm{m}^{-2}$.

Phosphate fertilization did not affect aboveground biomass in 2000, but did in 2002. In Lumaco and Selva Oscura, dry matter at flowering increased from $2919 \mathrm{~kg}$ ha $^{-1}$ in controls where $\mathrm{P}$ was not applied to $7483 \mathrm{~kg} \mathrm{ha}^{-1}$ with $109 \mathrm{~kg} \mathrm{P} \mathrm{ha}^{-1}$ and 3489 to $5560 \mathrm{~kg} \mathrm{ha}^{-1}$, respectively (data not shown). Plant height increased at least $10 \mathrm{~cm}$ as a result of $\mathrm{P}$ fertilization. Controls with no $\mathrm{P}$ were $47 \mathrm{~cm}$ tall during full flowering, whereas plots receiving P measured $57-63 \mathrm{~cm}$ with no significant differences between $P$ rates.
The chemical characterization of the aboveground biomass during grass pea flowering in Lumaco in 2000 is shown in Table 4. Phosphate fertilization did not apparently affect neither $\mathrm{N}$ content, which was relatively high nor $\mathrm{P}$, $\mathrm{K}, \mathrm{Ca}, \mathrm{Mg}$, and micronutrients. Nutrient absorption by the aboveground biomass up to the flowering stage in Lumaco is presented in Table 5. In general, macro and micronutrients appeared to be absorbed to a greater extent with higher rates of $\mathrm{P}$ fertilization.

Nutrient content in the grass pea grain from both sites was unaffected by $\mathrm{P}$ treatments in 2000 (Table 6). However, mean $\mathrm{N}$ content of grain from Selva Oscura was less than that from Lumaco, probably due to limitations on symbiotic $\mathrm{N}$ fixation from high soil acidity associated with the above-mentioned $\mathrm{Al}$ saturation condition. On the contrary, $\mathrm{P}, \mathrm{K}, \mathrm{Zn}$, and $\mathrm{Cu}$ were notably greater in grain from Selva Oscura than from Lumaco, and this was true to a lesser extent for $\mathrm{Ca}, \mathrm{Mg}, \mathrm{Mn}$, and $\mathrm{B}$. In general, nutrient absorption by grass pea grain was higher with increased $\mathrm{P}$ fertilization (Table 7), due to the better yield associated with it. Absorption means were lower in Selva Oscura because of lower yields. 
Table 6. Nutrient content of grass pea grain cv. Luanco-INIA in Lumaco and Selva Oscura, southern Chile in $2000-2001$ for six rates of $P$ fertilization.

\begin{tabular}{|c|c|c|c|c|c|c|c|c|c|}
\hline Applied phosphorus & $\mathbf{N}$ & $\mathbf{P}$ & $\mathbf{K}$ & Ca & Mg & Zn & Mn & $\mathrm{Cu}$ & B \\
\hline $\mathrm{kg} \mathrm{ha}^{-1} \mathrm{P}$ & & 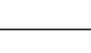 & $\%-$ & & & 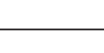 & - m & & \\
\hline \multicolumn{10}{|l|}{ Lumaco } \\
\hline 0.0 & 4.0 & 0.23 & 0.67 & 0.10 & 0.09 & 23 & 22 & 5 & 6 \\
\hline 21.8 & 4.2 & 0.28 & 0.73 & 0.10 & 0.09 & 24 & 19 & 5 & 8 \\
\hline 43.6 & 3.9 & 0.20 & 0.67 & 0.11 & 0.09 & 19 & 22 & 5 & 8 \\
\hline 65.4 & 4.5 & 0.20 & 0.69 & 0.10 & 0.08 & 21 & 22 & 5 & 9 \\
\hline 87.2 & 4.0 & 0.23 & 0.65 & 0.10 & 0.09 & 24 & 21 & 5 & 8 \\
\hline 109.0 & 4.2 & 0.18 & 0.67 & 0.11 & 0.09 & 20 & 23 & 5 & 8 \\
\hline Mean & 4.1 & 0.22 & 0.68 & 0.10 & 0.09 & 21.8 & 21.5 & 5.0 & 7.8 \\
\hline \multicolumn{10}{|l|}{ Selva Oscura } \\
\hline 0.0 & 3.6 & 0.37 & 0.90 & 0.13 & 0.11 & 32 & 24 & 8 & 10 \\
\hline 21.8 & 3.6 & 0.37 & 0.90 & 0.12 & 0.11 & 31 & 23 & 7 & 8 \\
\hline 43.6 & 3.3 & 0.36 & 0.91 & 0.12 & 0.11 & 30 & 24 & 8 & 9 \\
\hline 65.4 & 3.6 & 0.37 & 0.91 & 0.11 & 0.11 & 30 & 24 & 7 & 9 \\
\hline 87.2 & 3.8 & 0.34 & 0.91 & 0.12 & 0.11 & 30 & 22 & 7 & 11 \\
\hline 109.0 & 3.8 & 0.36 & 0.90 & 0.11 & 0.11 & 30 & 25 & 7 & 10 \\
\hline Mean & 3.6 & 0.36 & 0.91 & 0.12 & 0.11 & 30.5 & 23.7 & 7.3 & 9.5 \\
\hline
\end{tabular}

Data are from a compound sample of three (Lumaco) and four (Selva Oscura) replicates.

Table 7. Nutrient accumulation by grass pea grain cv. Luanco-INIA in Lumaco and Selva Oscura, southern Chile, 20002001, for six rates of $\mathbf{P}$ fertilization.

\begin{tabular}{|c|c|c|c|c|c|c|c|c|c|}
\hline Applied phosphorus & $\mathbf{N}$ & $\mathbf{P}$ & $\mathbf{K}$ & Ca & Mg & Zn & Mn & $\mathrm{Cu}$ & B \\
\hline $\mathrm{kg} \mathrm{ha}^{-1} \mathrm{P}$ & 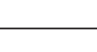 & 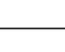 & $\mathrm{kg} \mathrm{ha}^{-1}$ & & & & - g & & \\
\hline \multicolumn{10}{|l|}{ Lumaco } \\
\hline 0.0 & 81 & 4.7 & 13.6 & 2.0 & 1.8 & 47 & 45 & 10 & 12 \\
\hline 21.8 & 97 & 6.5 & 16.9 & 2.3 & 2.1 & 56 & 44 & 12 & 19 \\
\hline 43.6 & 95 & 4.9 & 16.4 & 2.7 & 2.2 & 46 & 54 & 12 & 20 \\
\hline 65.4 & 122 & 5.4 & 18.7 & 2.7 & 2.2 & 57 & 60 & 14 & 24 \\
\hline 87.2 & 113 & 6.5 & 18.3 & 2.8 & 2.5 & 68 & 59 & 14 & 23 \\
\hline 109.0 & 113 & 4.8 & 17.9 & 2.9 & 2.4 & 54 & 62 & 13 & 21 \\
\hline Mean & 103.5 & 5.5 & 17.0 & 2.6 & 2.2 & 54.7 & 54.0 & 12.5 & 19.8 \\
\hline \multicolumn{10}{|l|}{ Selva Oscura } \\
\hline 0.0 & 27 & 2.8 & 6.7 & 1.0 & 0.8 & 24 & 18 & 6 & 8 \\
\hline 21.8 & 33 & 3.4 & 8.2 & 1.1 & 1.0 & 29 & 21 & 6 & 7 \\
\hline 43.6 & 34 & 3.7 & 9.4 & 1.2 & 1.1 & 31 & 25 & 8 & 9 \\
\hline 65.4 & 42 & 4.3 & 10.5 & 1.3 & 1.3 & 35 & 28 & 8 & 10 \\
\hline 87.2 & 50 & 4.4 & 11.9 & 1.6 & 1.4 & 39 & 29 & 9 & 14 \\
\hline 109.0 & 53 & 5.0 & 12.5 & 1.5 & 1.5 & 42 & 35 & 10 & 14 \\
\hline Mean & 39.8 & 3.9 & 9.9 & 1.3 & 1.2 & 33.3 & 26.0 & 7.8 & 10.3 \\
\hline
\end{tabular}

Nutrient accumulation was calculated by multiplying nutrient content by grain yield. 


\section{CONCLUSIONS}

Phosphate fertilization was associated with higher grass pea yields in soils with low $\mathrm{P}$ availability and retention capacity. The grain yield potential of grass pea in southern Chile was confirmed to be quite high, although grain yield was linked to the amount of rainfall during the cropping season. In a dryland area, high rainfall in spring may decrease the effect of $\mathrm{P}$ fertilization on grain yield. With a limited water supply, a growing condition that is frequent for this crop, grass pea crops should respond to $\mathrm{P}$ fertilization in soils with available P-Olsen $\leq 10 \mathrm{mg} \mathrm{kg}^{-1}$.

\section{ACKNOWLEDGEMENTS}

Research funded through FNDR Project BIP 20155696-0, granted by Gobierno Regional de La Araucanía, Chile. We are grateful to Colin Hanbury, Department of Agriculture and Food, W. Australia, and Jairo Palta, CSIRO Plant Industry, W. Australia, for help in improving the manuscript. Thanks are also due to Nelba Gaete and Héctor Pauchard, INIA-Carillanca, for providing climatic data and technical assistance.

\section{RESUMEN}

La fertilización fosfatada puede incrementar el rendimiento de cultivos productivos de chícharo (Lathyrus sativus L.) en suelos con retención de fósforo. La información sobre el requerimiento de fósforo de cultivos de chícharo (Lathyrus sativus L.) es muy escasa, particularmente en suelos que retienen este elemento. En consecuencia, se evaluó el efecto de la fertilización fosfatada sobre el rendimiento y peso del grano de chícharo (variedad Luanco-INIA) en suelos con baja disponibilidad de $\mathrm{P}$ y alta capacidad de retención de $\mathrm{P}$, en campos de pequeños agricultores de la Región de La Araucanía, sur de Chile (37³0'-39³0'S). Los ensayos se realizaron durante 2000-2001, 2001-2002 y 2002-2003 en seis sitios; tres en el área de Lumaco y tres en el área de Selva Oscura. Se evaluaron seis dosis de $\mathrm{P}(0 ; 21,8 ; 43,6 ; 65,4 ; 87,2$ y 109,0 $\mathrm{kg} \mathrm{ha}^{-1}$ ) en un diseño de bloques completos al azar con cuatro repeticiones. Se sembró a razón de 47 semillas $\mathrm{m}^{-2}$. El rendimiento de grano de todos los ensayos promedió $2456 \mathrm{~kg} \mathrm{ha}^{-1}$. La fertilización fosfatada incrementó el rendimiento de grano del chícharo durante las temporadas agrícolas 2000-2001 y 2001-2002, en ambas áreas. No hubo efecto significativo en 2002-2003, temporada de cultivo con una caída pluviométrica inusualmente elevada en primavera-verano, lo cual podría haber aumentado la tasa de mineralización de $\mathrm{P}$ desde la fracción orgánica del suelo y en consecuencia la disponibilidad de P. Asimismo, es posible que el crecimiento del sistema radical haya sido favorecido y con ello la exploración de un mayor volumen de suelo. De acuerdo a este estudio, cultivos de chícharo de esta variedad, en suelos con menos de $10 \mathrm{mg} \mathrm{kg}^{-1}$ de P-Olsen disponible, deberían responder a la fertilización fosfatada.

Palabras clave: almorta, Lathyrus, fósforo, cultivos desatendidos, leguminosas de grano de estación templada fría.

\section{LITERATURE CITED}

Besoaín, E., y A. Sadzawka. 1999. Fenómenos de retención de fósforo en los suelos volcánicos y sus consecuencias. p. 27-36. In Besoaín, E., C. Rojas, y A. Montenegro (eds.) Las rocas fosfóricas y sus posibilidades de uso agrícola en Chile. Instituto de Investigaciones Agropecuarias, Santiago, Chile.

Campbell, C.G. 1997. Grass pea. Lathyrus sativus L. Promoting the conservation and use of underutilized and neglected crops. Vol. 18. 92 p. Institute of Plant Genetics and Crop Plant Research, Gatersleben, Germany/International Plant Genetic Resources Institute, Rome, Italy.

Campbell, C.G., R.B. Mehra, S.K. Agrawal, Y.Z. Chen, A.M. Abd El Moneim, H.I.T. Khawaja, et al. 1994. Current status and future strategy in breeding grass pea (Lathyrus sativus). Euphytica 73:167-175.

Casanova, M., W. Vera, y W. Luzio. 2006. Rasgos morfológicos de los suelos. p. 43-90. In Luzio, W., y M. Casanova (eds.) Avances en el conocimiento de los suelos de Chile. Universidad de Chile, Santiago, Chile.

CIREN. 2002. Descripciones de suelos, materiales y símbolos. Estudio agrológico IX Región. Publicación $N^{\circ}$ 122. 360 p. Centro de Información de Recursos Naturales (CIREN), Santiago, Chile.

CIREN. 2003. Descripciones de suelos, materiales y símbolos. Estudio agrológico X Región. Tomo II. Publicación No 123. 412 p. Centro de Información de Recursos Naturales (CIREN), Santiago, Chile.

Ellena, M. 1983. Efecto del distanciamiento entre hileras y diferentes fórmulas de fertilización sobre los rendimientos y sus componentes en chícharos (Lathyrus sativus L.). Tesis Ingeniero Agrónomo. Universidad Austral de Chile, Facultad de Ciencias Agrarias, Valdivia, Chile.

Hanbury, C.D., C.L. White, B.P. Mullan, and K.H.M. Siddique. 2000. A review of the potential of Lathyrus sativus $\mathrm{L}$. and $L$. cicera $\mathrm{L}$. grain for use as animal feed. Anim. Feed Sci. Technol. 87:1-27. 
Krarup, A. 2002. Blanco Austral, cultivar de chícharo (Lathyrus sativus L.) obtenido por selección del rendimiento por planta y de sus componentes. Agrosur 30:40-46.

Lambein, F., Y.H. Kuo, K. Kusama-Eguchi, and F.I. Ikegami. 2007. 3-N-Oxalyl-L-2,3-diaminopropanoic acid, a multifunctional plant metabolite of toxic reputation. Arkivoc 2007(9):45-52.

Mera, M., J. Tay, A. France, A. Montenegro, N. Espinoza, N. Gaete, and L. Barrientos. 2003. Luanco-INIA, a large-seeded cultivar of Lathyrus sativus released in Chile. Lathyrus Lathyrism Newsletter 3:26.

Montenegro, A. 1991. Diagnóstico preliminar de los tenores de nitrógeno, fósforo, potasio, materia orgánica y pH de los suelos de la IX Región. Investigación y Progreso Agropecuario Carillanca 10(3):3-11.

Montenegro, A., E. Besoaín, y C. Toro. 1999b. Aplicación directa de rocas fosfóricas y mezclas de rocas con fertilizantes fosfatados solubles en el cultivo del raps, en Andisoles de la IX Región. p. 255-270. In Besoaín, E., C. Rojas, y A. Montenegro (eds.) Las rocas fosfóricas y sus posibilidades de uso agrícola en Chile. Instituto de Investigaciones Agropecuarias, Santiago, Chile.

Montenegro, A., E. Besoaín, C. Toro, y E. Contreras. 1999a. Evaluación agronómica del uso de rocas fosfóricas en la fertilización fosfatada del trigo, en suelos derivados de cenizas volcánicas de la IX Región. p. 217-241. In Besoaín, E., C. Rojas, y A. Montenegro (eds.) Las rocas fosfóricas y sus posibilidades de uso agrícola en Chile. Instituto de Investigaciones Agropecuarias, Santiago, Chile.

Montenegro, A., M. Mera, N. Espinoza, L. Barrientos, and N. Gaete. 2001. Effect of phosphate fertilization on Lathyrus sativus in soils with high phosphorus retention capacity. Lathyrus Lathyrism Newsletter 2:95-98.
Pino, I., W. Luzio, y A.M. Parada. 1998. Cinética de intercambio isotópico en suelos derivados de cenizas volcánicas. Un modelo predictivo. Agric. Téc. (Chile) 58:56-64.

Sadzawka, A., R. Campillo, A. Montenegro, y C. Rojas. 1999. Determinación de la capacidad tampón de fósforo en suelos ácidos. p. 49. In Salazar, I. (ed.) Proceedings $14^{\circ}$ Congreso Latinoamericano de la Ciencia del Suelo, Pucón, Chile. 8-12 noviembre 1999. Universidad de La Frontera, Temuco, Chile.

Sadzawka, A., M. Carrasco, R. Grez, M.L. Mora, H. Flores, y A. Neaman. 2006. Métodos de análisis recomendados para los suelos de Chile. Revisión 2006. Serie Actas INIA No 34.164 p. Instituto de Investigaciones Agropecuarias, Santiago, Chile.

Sadzawka, A., M. Carrasco, R. Demanet, H. Flores, R. Grez, M.L. Mora, y A. Neaman. 2007. Métodos de análisis de tejidos vegetales. $2^{\mathrm{a}}$ ed. Serie Actas INIA ${ }^{\circ}$ 40. 140 p. Instituto de Investigaciones Agropecuarias, Santiago, Chile.

Sarkar, R.K., B. Biswas, and G.C. Malik. 2003. Productivity of grass pea (Lathyrus sativus L.) under different levels of phosphorus and foliar spray of molybdenum. Lathyrus Lathyrism Newsletter 3:3637.

SAS Institute. 1992. STAT@ User's guide for personal computers. 704 p. 8th ed. SAS Institute, Cary, North Carolina, USA.

Siddique, K.H.M., C.L. Hanbury, and A. Sarker. 2006. Registration of 'Ceora' grass pea. Crop Sci. 46:986.

Siddique, K.H.M., S.P. Loss, S.P. Herwig, and J.M. Wilson. 1996. Growth, yield and neurotoxin (ODAP) concentration of three Lathyrus species in Mediterranean-type environments of Western Australia. Aust. J. Exp. Agric. 36:209-218. 


\title{
ORGANIC MATTER REDUCES COPPER TOXICITY FOR THE EARTHWORM Eisenia fetida IN SOILS FROM MINING AREAS IN CENTRAL CHILE
}

\author{
Gonzalo Ávila, Hernán Gaete², Sébastien Sauvé ${ }^{3}$, and Alexander Neaman ${ }^{14^{*}}$
}

\begin{abstract}
The Aconcagua River basin (Central Chile) is one of the most important agricultural areas in the country. However, several copper $(\mathrm{Cu})$ mining operations are located in the basin. The objective of the study was to determine $\mathrm{Cu}$ toxicity for the earthworm Eisenia fetida (Savigny 1826) in the agricultural soils of the basin. We determined the production of cocoons and juveniles of earthworms in the studied soils. The soils differed in the concentrations of organic matter (OM, range 2-6\%), pH (range 7.3-8.3), texture (from loamy sand to clay loam), and total $\mathrm{Cu}$ concentrations (range 230-960 $\mathrm{mg} \mathrm{kg}^{-1}$ ). Concentrations of $\mathrm{Cu}$ and $\mathrm{OM}$ in the soils were the variables that determined the earthworms' biological response. In contrast, $\mathrm{pH}$ and texture did not affect this response. Cocoon and juvenile production decreased considerably in soils with elevated $\mathrm{Cu}$ concentrations ( $\left.>500 \mathrm{mg} \mathrm{kg}^{-1}\right)$, regardless of OM concentrations. Cocoon production decreased in the soils with $\mathrm{Cu}$ concentrations below $500 \mathrm{mg} \mathrm{kg}^{-1}$ when $\mathrm{OM}$ concentrations were below 3.5\%. In contrast, cocoon production did not vary when OM concentrations were above $3.5 \%$. The same effect of OM was observed on juvenile production. In this case, the threshold for OM concentration was $2.5 \%$. It was concluded that it is important to consider OM concentrations in order to predict the biological response of earthworms in these soils.
\end{abstract}

Key words: Eisenia fetida, Aconcagua River, ecological risk assessment, $\mathrm{Cu}$ mining, trace elements.

\section{INTRODUCTION}

Copper $(\mathrm{Cu})$ mining is the most important economic activity in Chile. However, the environmental problems historically associated with copper mining are widely known, particularly in relation to the contamination of agricultural soils by trace elements such as $\mathrm{Cu}$ (González et al., 2008; De Gregori et al., 2003). Although $\mathrm{Cu}$ is an essential element for all organisms, it becomes toxic at high concentrations (Sauvé et al., 1998).

The Aconcagua River basin in Central Chile is one of the most important agricultural areas in the country. On the other hand, several copper mining industries are located in the agricultural areas of the basin. There is little information available about the toxicity of copper for organisms and crops in agricultural soils of Chile.

${ }^{1}$ Pontificia Universidad Católica de Valparaíso, Facultad de Agronomía, Casilla 4-D, Quillota, Chile.

"Corresponding author (alexander.neaman@ucv.cl).

${ }^{2}$ Universidad de Valparaíso, Facultad de Ciencias, Av. Gran Bretaña 1111, Valparaíso, Chile.

${ }^{3}$ Université de Montréal, Département de Chimie, CP 6128 Centreville, Montréal, QC, H3C 3J7, Canada.

${ }^{4}$ Centro Regional de Estudios en Alimentos Saludables (CREAS), Blanco 1623, Of. 1402, Valparaíso, Chile.

Received: 11 June 2008.

Accepted: 06 July 2008.
Knowing the total concentration of a trace element in a soil is not sufficient to predict the potential ecological risk that it represents (Sauvé et al., 1998). Ecological risk is more related to the bioavailability of the element that, in turn, is related to the chemical form in which it is found in the soil. The National Research Council (NRC, 2003) defines bioavailability as the fraction of the total element that is available to the receptor organism.

Chile currently does not have any legislation on the maximum acceptable concentrations of toxic elements in soils. In the opinion of the authors based on what is outlined above, any future legislation should distinguish between soils where trace elements are present but do not represent a risk from those that, at similar concentration of trace elements, do represent significant ecological risks.

An approximation that can be used to solve this problem is carrying out toxicity bioassays with soil macroorganisms. Standardized bioassays that determine the acute and chronic toxicity with earthworm E. fetida are particularly suitable (OECD, 2000). E. fetida is considered representative of soil macrofauna and of earthworms in particular (OECD, 2000). The objective of the present study was to determine the toxicity of trace elements for earthworms in agricultural soils from mining areas in Central Chile. 


\section{MATERIALS AND METHODS}

\section{Site selection and soil sampling}

The selection of sampling sites was based on the results of a previous study on the distribution of copper in agricultural soils in the Aconcagua River basin (R. Aguilar, unpublished results). This study revealed that the Catemu Creek sub-basin has the largest surface area of soils with high concentrations of $\mathrm{Cu}$.

With the objective of obtaining samples with a wide range of total $\mathrm{Cu}$ concentration, 13 localities of the Catemu Creek sub-basin were sampled (Table 1). In each locality, $10 \mathrm{~kg}$ of soil were obtained, from a soil depth of 0 to 20 $\mathrm{cm}$, following the removal of the existing vegetation. The soils were then taken to the laboratory of the Faculty of Agriculture, Pontifical Catholic University of Valparaiso, where they were dried at $60{ }^{\circ} \mathrm{C}$ for 2 days. Then, the soils were disaggregated in a porcelain mortar and sieved to 2 $\mathrm{mm}$.

\section{Physical-chemical analysis of the soils}

The total concentrations of $\mathrm{Cu}$, lead $(\mathrm{Pb})$ and zinc $(\mathrm{Zn})$ were determined by atomic absorption spectrophotometry (GBC, model 902, Dandenong, Victoria, Australia) following acid digestion of the soils with a mixture of fluorhydric and perchloric acids (Maxwell, 1968). The determination of total arsenic (As) in the soils was carried out using neutron activation analysis. To ensure the quality of the results, reference samples were analyzed. For all the cases, the percentage of difference between the obtained values versus the certified values did not exceed $10 \%$.
The soil texture was determined using the simplified hydrometer method according to Sheldrick and Wang (1993). The concentration of organic matter (OM) was determined according to Sadzawka et al. (2006). Electrical conductivity (EC) and $\mathrm{pH}$ were determined in saturated paste extracts (Sadzawka et al., 2006). Soluble $\mathrm{Cu}$ concentration and activity of free $\mathrm{Cu}^{2+}$ ion $\left(\mathrm{pCu}^{2+}\right)$ were determined in the same extract by atomic absorption spectrophotometry and by ion selective electrode (Rachou et al., 2007a), respectively.

\section{Bioassays of toxicity}

To determine chronic toxicity, bioassays with the earthworm Eisenia fetida were carried out using the protocols of the OECD (2000). Specifically, $500 \mathrm{~g}$ of soil was adjusted to a humidity of $40 \% \mathrm{w} / \mathrm{w}$ and placed in experimental glass containers of $750 \mathrm{~mL}$. Ten adult earthworms (with visible clitellum) were incubated in each container. Earthworms were previously washed with distilled water, blotted dry and weighed. Five grams of cow manure were moistened with $5 \mathrm{~mL}$ of distilled water and added to each container. Eight replicates were made with each soil. The design was randomized. After 4 weeks of exposure, the weight, adult survival and number of cocoons were determined. Then, the cocoons were incubated in the same soil for additional 4 weeks and the number of juveniles was determined. Room temperature was maintained within the range of 22 to $24{ }^{\circ} \mathrm{C}$, with illumination of 200 lux and a photoperiod of $12 \mathrm{~h}$ of light and $12 \mathrm{~h}$ of darkness. Moisture was maintained by the application of $40 \mathrm{~mL}$ of distilled water once a week. Soil 41 was considered as a control because of the lowest concentrations of $\mathrm{Cu}$ among the studied soils (Table 1).

Table 1. Physico-chemical characteristics of the studied soils.

\begin{tabular}{|c|c|c|c|c|c|c|c|c|c|c|}
\hline Soil & Texture & OM & $\mathrm{Cu}$ & $\mathbf{P b}$ & Zn & As & CE & pH & $\mathbf{p C u}^{2+}$ & $\mathbf{C u}$ \\
\hline & & $\%$ & 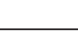 & $-\mathrm{m}$ & -1 & 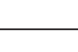 & $\mathrm{dS} \mathrm{m}^{-1}$ & & & $\mathrm{mg} \mathrm{L}^{-1}$ \\
\hline 18 & Sandy loam & 5.2 & 959 & 542 & 923 & 44 & 2.3 & 7.3 & 7.3 & 2.70 \\
\hline 27 & Sandy loam & 3.5 & 847 & 81 & 209 & 19 & 2.4 & 7.9 & 7.9 & 0.74 \\
\hline 28 & Loam & 2.2 & 382 & 81 & 244 & 17 & 1.3 & 8.0 & 8.0 & 0.28 \\
\hline 29 & Loam & 4.0 & 431 & 30 & 156 & 21 & 0.8 & 8.3 & 8.3 & 0.67 \\
\hline 30 & Clay loam & 5.2 & 426 & 46 & 135 & 30 & 2.2 & 7.6 & 7.6 & 0.29 \\
\hline 31 & Loam & 5.3 & 354 & 36 & 117 & 24 & 2.9 & 8.1 & 8.1 & 0.56 \\
\hline 37 & Loamy sand & 2.0 & 354 & 36 & 97 & 30 & 2.6 & 7.9 & 7.9 & 0.38 \\
\hline 38 & Loam & 3.5 & 434 & 40 & 117 & 28 & 2.5 & 7.9 & 7.9 & 0.22 \\
\hline 41 & Loam & 6.0 & 226 & 36 & 148 & 29 & 4.8 & 7.8 & 7.8 & 0.60 \\
\hline 49 & Loam & 5.6 & 707 & 47 & 134 & 37 & 4.1 & 8.0 & 8.0 & 0.83 \\
\hline 50 & Clay loam & 4.0 & 650 & 63 & 146 & 45 & 1.5 & 8.2 & 8.2 & 0.46 \\
\hline 52 & Loam & 2.8 & 597 & 47 & 133 & 36 & 2.1 & 8.2 & 8.2 & 0.48 \\
\hline
\end{tabular}

OM: organic matter. $\mathrm{CE}$ : electrical conductivity. $\mathrm{pCu}^{2+}:-\log$ (activity of the free $\mathrm{Cu}^{2+}$ ion). 


\section{Statistical analysis}

Using the Dunnett test, comparisons between the responses of the earthworms in the studied soils and the control soil have been made. Simple and multiple regressions were made between the responses of the earthworms and the physico-chemical characteristics of the soils. Also, simple regressions were made between the concentrations of $\mathrm{Pb}, \mathrm{Zn}$ or As and those of $\mathrm{Cu}$. We used the Minitab 3.1 and Excel 2003 for statistical analysis.

\section{RESULTS AND DISCUSSION}

\section{Soil characterization}

The studied soils were different in OM concentrations (range of $2-6 \%$ ), EC (range of $0.8-4.8 \mathrm{dS} \mathrm{m}^{-1}$ ), $\mathrm{pH}$ (range of 7.3 - 8.3) and texture (from loamy sand to clay loam). The soils presented a wide range of total $\mathrm{Cu}$ concentration (from 230 to $960 \mathrm{mg} \mathrm{kg}^{-1}$ ) (Table 1). These high $\mathrm{Cu}$ concentrations are mainly due to mining activities, while application of copper-based products in agriculture represents a minor source (R. Aguilar, unpublished results). Simple regressions revealed that the relations between the concentrations of $\mathrm{Pb}, \mathrm{Zn}$ and As (Table 1) versus those of $\mathrm{Cu}$ were not significant $(\mathrm{P}>$ $0.05)$.

\section{Validity of the control soil}

The OECD (2000) established the following criteria for validity of the control soil: (1) each repetition (10 adult earthworms) should produce at least 30 juveniles at the end of the bioassay, (2) the variation coefficient in the reproduction parameters must be less than $30 \%$, and (3) adult mortality must be less than $10 \%$. Additional to this, Spurgeon et al. (2003) propose that weight loss should be less than $15 \%$. These four criteria were satisfied in the control soil (Table 2).

\section{Survival and weight loss}

In all the soils used, the earthworm survival was higher than $98 \%$ and weight loss did not exceed $20 \%$ (Table 2). The data of survival presented a very narrow range (98$100 \%$ ) and, thus, it was not possible to carry out regressions with the physico-chemical characteristics of the soils. On the other hand, the physico-chemical characteristics of the soils did not explain weight variation. As shown below, the survival and weight loss are variables that less sensitive to $\mathrm{Cu}$ toxicity, in comparison to the reproduction variables.

\section{Identification of the variables that affected reproduction}

Bioassays with earthworms have been widely used to determine the toxicity of trace elements in soils (Spurgeon et al., 2003). However, the technique has been criticized for not adequately representing real environmental conditions and, consequently, not being relevant from an environmental point of view (Davies et al., 2003). The criticism is based on the fact that the OECD (2000) proposes the use of artificial soils (composed of peat, clay, and sand) enriched with solutions of metals at increasing concentrations. In fact, it has been observed that the toxicity of trace elements for earthworms is considerably higher in artificially-contaminated soil media than in field-collected soils. This is explained by a greater bioavailability of trace

Table 2. Results of chronic toxicity bioassays (OECD, 2000). Soil 41 was considered as a control (C).

\begin{tabular}{|c|c|c|c|c|c|}
\hline Soil & Survival & Weight loss & Number of cocoons & Number of juveniles & $\mathrm{Cu}$ in earthworms \\
\hline & 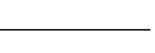 & $\longrightarrow$ & & & $\mathrm{mg} \mathrm{kg}^{-1}$ \\
\hline $41(\mathrm{C})$ & $100 \pm 0$ & $(-) 14 \pm 3.8$ & $28 \pm 3.2$ & $54 \pm 4.4$ & $23 \pm 0.8$ \\
\hline 18 & $100 \pm 0$ & $(-) 4 \pm 8.9$ & $11 \pm 6.5^{*}$ & $19 \pm 17^{*}$ & $61 \pm 31^{*}$ \\
\hline 27 & $99 \pm 3.5$ & $(-) 8 \pm 5.4$ & $6 \pm 4.0^{*}$ & $14 \pm 9.0^{*}$ & $64 \pm 4.4^{*}$ \\
\hline 28 & $100 \pm 0$ & $(-) 10 \pm 9.7$ & $9 \pm 5.6^{*}$ & $8 \pm 9.8^{*}$ & $37 \pm 0.4$ \\
\hline 29 & $100 \pm 0$ & $(-) 15 \pm 3.5$ & $26 \pm 5.2$ & $50 \pm 12$ & $37 \pm 3.8$ \\
\hline 30 & $98 \pm 4.6$ & (-) $8 \pm 5.8$ & $18 \pm 3.0^{*}$ & $36 \pm 4.4^{*}$ & $39 \pm 1.9$ \\
\hline 31 & $100 \pm 0$ & (+) $1 \pm 3.9^{*}$ & $20 \pm 4.1^{*}$ & $41 \pm 5.7$ & $51 \pm 4.5^{*}$ \\
\hline 37 & $100 \pm 0$ & (-) $8 \pm 4.5$ & $15 \pm 6.3^{*}$ & $23 \pm 7.9^{*}$ & $41 \pm 2.9$ \\
\hline 38 & $99 \pm 3.5$ & (+) $2 \pm 6.8^{*}$ & $15 \pm 5.5^{*}$ & $41 \pm 17$ & $59 \pm 3.5^{*}$ \\
\hline 49 & $100 \pm 0$ & $(-) 19 \pm 8.0$ & $9 \pm 5.1^{*}$ & $24 \pm 12 *$ & $46 \pm 0.6$ \\
\hline 50 & $98 \pm 4.6$ & $(-) 6 \pm 6.8$ & $4 \pm 3.1^{*}$ & $14 \pm 7.8^{*}$ & $46 \pm 0.6$ \\
\hline 52 & $100 \pm 0$ & (+) $2 \pm 12 *$ & $5 \pm 4.3^{*}$ & $13 \pm 6.8^{*}$ & $37 \pm 27$ \\
\hline
\end{tabular}

* Significantly different from the control according to the Dunnett test $(\mathrm{P}<0.05)$.

\pm : Standard deviation. $(-)=$ Weight loss. $(+)=$ Weight increase. 
elements in artificially-contaminated soils in comparison to those collected in the field (Spurgeon and Hopkin, 1995). As a result, recent studies highlight the importance of using field-collected soils to evaluate ecological risk of trace elements present in the soil (Nahmani et al., 2007a; 2007b).

On the other hand, the use of field-collected soils presents several difficulties. First, in areas near copper mining activities, soils have high concentrations of several trace elements $(\mathrm{Cu}, \mathrm{Pb}, \mathrm{Zn}, \mathrm{Cd}$ and $\mathrm{As}$, among others; De Gregori et al., 2003; Ginocchio et al., 2004). In this case, it could be difficult to distinguish between the effects of different trace elements on the response of the earthworms. Second, agricultural soils can contain other types of chemical compounds, such as pesticides and/or fungicides, which can affect the response of the earthworms (Slimak, 1997). Finally, the intrinsic physicochemical characteristics of the soil, such as $\mathrm{pH}$, texture and OM content, among others, also affect the degree of toxicity of the trace elements present in the soil (Kennette et al., 2002, Nahmani et al., 2007a).

In the present study, the variables that affected earthworm reproduction were identified using simple and multiple regressions between earthworm responses and the physico-chemical characteristics of the soils. The regressions ruled out any evident effects of $\mathrm{Pb}, \mathrm{Zn}$, and $\mathrm{As}$ on the response of earthworms. The simple and multiple regressions between earthworm reproduction and the physico-chemical characteristics of the soils indicated that $\mathrm{pH}$, texture, $\mathrm{EC}$, and soluble $\mathrm{Cu}$ concentration did not affect the response of the earthworms. On the other hand, a significant regression was observed between $\mathrm{pCu}^{2+}$ and earthworm reproduction (Table 3). The effect of free $\mathrm{Cu}^{2+}$ ion will be discussed in detail below.

The best prediction of the earthworm response was obtained by considering total $\mathrm{Cu}$ concentrations together with OM (Table 3). The regression coefficients increased upon considering both variables together, in comparison to total $\mathrm{Cu}$ alone. This effect of $\mathrm{OM}$ on $\mathrm{Cu}$ toxicity will be discussed in detail below.
Thus, the effects observed on earthworm reproduction are mainly due to $\mathrm{Cu}$ and $\mathrm{OM}$, explaining about $70 \%$ of the variance (Table 3). Nevertheless, the studied soils could contain other undetermined compounds (for example, pesticides and/or fungicides) that have affected earthworm reproduction.

\section{Effect of OM on the toxicity of copper}

The earthworm E. fetida lives in environments rich in OM (OECD, 2000). Despite this, the regressions between OM concentrations and earthworm reproduction were not significant. This suggests that $\mathrm{OM}$ does not have a direct effect on the reproduction parameters. This concurs with Spurgeon and Hopkin (1999) who indicated that E. fetida was not able to obtain sufficient nutrients from mineral soils (with $\mathrm{OM}<20 \%$ ), requiring the addition of food to the soils used in the bioassays.

The multiple regressions show that $\mathrm{OM}$ promotes cocoon and juvenile production, while total $\mathrm{Cu}$ decreases earthworm reproduction. Consequently, it is necessary to consider OM content to predict the biological responses of earthworms in soils contaminated with trace elements.

The soils with more than $50 \%$ of inhibition in the production of cocoons or juveniles are considered as toxic for earthworms (Hund-Rinke and Wiechering, 2001; HundRinke et al., 2005). The soils with total $\mathrm{Cu}$ concentrations higher than $500 \mathrm{mg} \mathrm{kg}^{-1}$ were toxic, independent of the OM concentrations (Figure 1). In contrast, in the soils with total $\mathrm{Cu}$ concentrations below $500 \mathrm{mg} \mathrm{kg}^{-1}$, OM concentrations determined Cu toxicity. In the case of cocoon production, the soils with total $\mathrm{Cu}$ concentrations below $500 \mathrm{mg} \mathrm{kg}^{-1}$ were toxic when OM concentrations were lower than 3.5\%. The opposite was observed in the case of OM concentrations above $3.5 \%$ (Figure 1). In the case of juvenile production in soils with total $\mathrm{Cu}$ concentrations below $500 \mathrm{mg} \mathrm{kg}^{-1}$, the critical threshold for OM concentration was about $2.5 \%$ (Figure 2).

The combined effect of total $\mathrm{Cu}$ and $\mathrm{OM}$ on the response of earthworms is due to the control that these two variables exert on the activity of the $\mathrm{Cu}^{2+}$ ion that

Table 3. Regressions between the number of cocoons/juveniles and soil copper concentrations.

\begin{tabular}{|c|c|c|c|c|c|}
\hline Production of cocoons & $\mathbf{R}^{2}$ & $\mathbf{P}$ & Production of juveniles & $\mathbf{R}^{2}$ & $\mathbf{P}$ \\
\hline $\mathrm{PC}=26+0.02 \mathrm{CuT}$ & 0.44 & 0.02 & $\mathrm{PJ}=50-0.04 \mathrm{CuT}$ & 0.34 & 0.05 \\
\hline $\mathrm{PC}=15-1.6 \mathrm{CuS}$ & 0.21 & 0.12 & $\mathrm{PJ}=30-3 \mathrm{CuS}$ & 0.23 & 0.10 \\
\hline $\begin{array}{r}\mathrm{PC}=16-0.03 \mathrm{CuT}+2.8 \mathrm{OM} \\
(0.005) \quad(0.03)\end{array}$ & 0.68 & 0.01 & $\begin{array}{r}\mathrm{PJ}=24-0.05 \mathrm{CuT}+6.8 \mathrm{OM} \\
(0.01) \quad(0.01)\end{array}$ & 0.68 & 0.01 \\
\hline $\mathrm{PC}=-69+8.5 \mathrm{pCu}^{2+}$ & 0.43 & 0.02 & $\mathrm{PJ}=-118+15 \mathrm{pCu}^{2+}$ & 0.35 & 0.04 \\
\hline
\end{tabular}

PC: Production of cocoons. PJ: production of juveniles. OM: organic matter (\%). CuT: total copper $\left(\mathrm{mg} \mathrm{kg}^{-1}\right)$. CuS: soluble copper $\left(\mathrm{mg} \mathrm{L}^{-1}\right)$. $\mathrm{pCu}^{2+}$ : - $\log$ (activity of the free $\mathrm{Cu}^{2+}$ ion). $\mathrm{R}^{2}$ : regression coefficient. $\mathrm{P}$ : probability. Number in parenthesis indicates the $\mathrm{P}$ value of the variable in multiple regressions. 


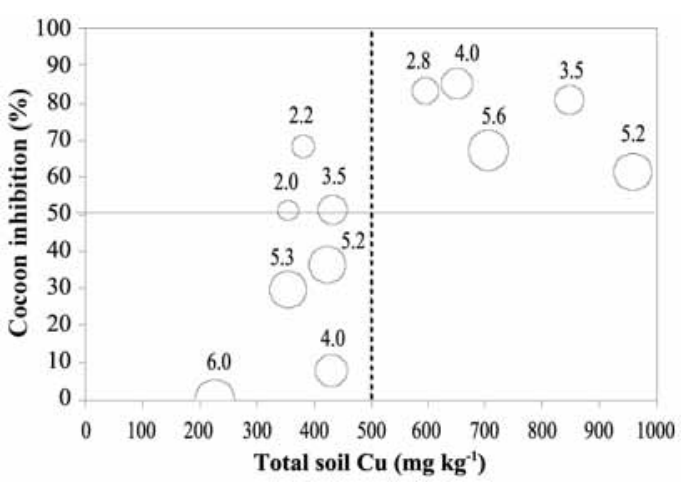

Figure 1. Effect of total copper and organic matter on cocoon production. The size of the circles and the values represent the percentage of organic matter in each soil.

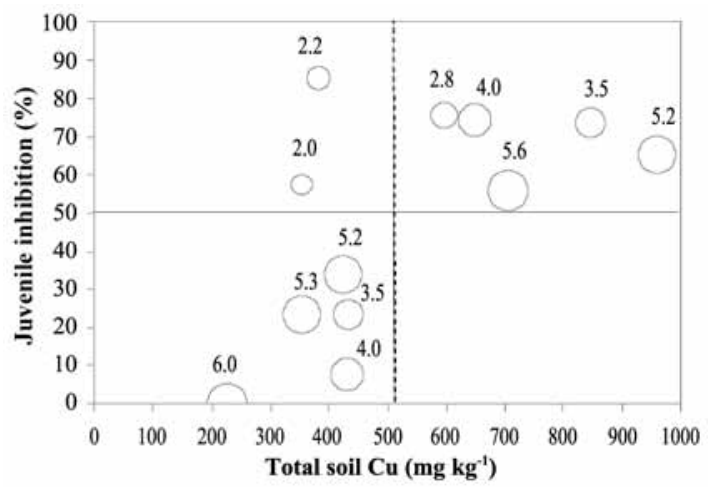

Figure 2. Effect of total copper and organic matter on juvenile production. The size of the circles and the values represent the percentage of organic matter in each soil.

is considered as the bioavailable form of $\mathrm{Cu}$ in the soil (Sauvé et al., 1998; Thakali et al., 2006). McBride et al. (1997) and Sauvé et al. (1997) proposed an empirical equation that describes the effect of the physico-chemical properties of the soil on the activity of the $\mathrm{Cu}^{2+}$ ion: $\mathrm{pCu}^{2+}$ $=\mathrm{a}+\mathrm{b} \mathrm{pH}+\mathrm{c} \log \mathrm{CuT}+\mathrm{d} \log \mathrm{OM}$. In agreement with this postulate, in the present study, the activity of the $\mathrm{Cu}^{2+}$ ion in the saturated paste extracts was controlled by the concentrations of $\mathrm{OM}$ and total $\mathrm{Cu}$ (Table 4). In turn, $\mathrm{pH}$ did not affect $\mathrm{pCu}^{2+}$, probably because of the narrow $\mathrm{pH}$ range in the studied soils ( $\mathrm{pH}$ of 7.3 to 8.3).

Also, the effect of $\mathrm{OM}$ in reducing $\mathrm{Cu}$ toxicity for earthworms is probably due to a change in the mobilization of copper from the solid phase to the soil solution. According to Rachou et al. (2007b), the kinetics of the mobilization of the elements from the solid phase to the soil solution decreases with increasing concentration of OM. Thus, the decrease in the flow of $\mathrm{Cu}$ from the solid phase to the soil solution can, in turn, reduce its toxicity for the earthworms.

\section{Effect of different forms of copper on reproduction}

The bioavailability of a trace element can be estimated through a chemical analysis that extracts a fraction of the element. Diverse extractants were proposed to simulate the bioavailability of trace elements for plants and soil organisms. It is often considered that the bioavailable fraction of a trace element corresponds to its soluble form (Posthuma et al., 1997; Kabata-Pendias, 2004). Nevertheless, the regressions between earthworm reproduction and $\mathrm{Cu}$ concentrations in the saturated paste extract, corresponding to the soluble form of $\mathrm{Cu}$ (Table 3), indicated that this form of the element did not affect the earthworms' reproduction.

On the other hand, the $\mathrm{Cu}^{2+}$ ion is the bioavailable form of $\mathrm{Cu}$ both in soil and water (Thakali et al., 2006). The activity of the $\mathrm{Cu}^{2+}$ ion is often considered to be the best variable to predict $\mathrm{Cu}$ toxicity for plants, organisms and microbial processes in the soil (Sauvé et al., 1998). In accordance with these postulates, in the present study, the regressions between $\mathrm{pCu}^{2+}$ in saturated paste extract and earthworms' reproduction were significant (Table 3).

\section{Bioaccumulation of copper}

Earthworms can actively excrete $\mathrm{Cu}$ assimilated in their tissues (Spurgeon and Hopkin, 1999). This implies extra energy costs, generating a reduction in energy available for growth and development. This, in turn, affects sexual maturity and production of cocoons and juveniles (Spurgeon and Hopkin, 1996). Likewise, the efficiency of excretion probably decreases with increasing concentrations of $\mathrm{Cu}$, resulting in increased bioaccumulation (i.e., the concentration of assimilated $\mathrm{Cu}$ in earthworm tissue) in the soils with higher $\mathrm{Cu}$ concentrations (Svendsen and Weeks, 1997; ScottFordsmand et al., 2000).

In the present study, the concentrations of total $\mathrm{Cu}$ in the soil explained $53 \%$ of the variance $(\mathrm{P}=0.001)$ in the bioaccumulation of $\mathrm{Cu}$. In contrast, other soil properties like $\mathrm{pH}, \mathrm{OM}$ and other forms of $\mathrm{Cu}$ (soluble or free) did

Table 4. Effect of total copper, organic matter and $\mathrm{pH}$ on $\mathrm{pCu}^{2+}$.

\begin{tabular}{|c|c|c|}
\hline & $\mathbf{R}^{2}$ & $\mathbf{P}$ \\
\hline $\mathrm{pCu}^{2+}=15-2 \log \mathrm{CuT}$ & 0.34 & 0.04 \\
\hline $\begin{array}{c}\mathrm{pCu}^{2+}=14-2 \log \mathrm{CuT}+1.9 \log \mathrm{OM} \\
(0.018)\end{array}$ & 0.59 & 0.01 \\
\hline $\begin{array}{rr}\mathrm{pCu}^{2+}=7-2 \log \mathrm{CuT}+2 \log \mathrm{OM}+0.8 \mathrm{pH} \\
(0.020) \quad(0.014) \quad(0.093)\end{array}$ & 0.72 & 0.01 \\
\hline
\end{tabular}

CuT: total copper $\left(\mathrm{mg} \mathrm{kg}^{-1}\right)$. OM: organic matter $(\%) \cdot \mathrm{pCu}^{2+}:-\log$ (activity of the free $\mathrm{Cu}^{2+}$ ion).

$\mathrm{R}^{2}$ : regression coefficient. P: probability. Numbers in parenthesis indicate the $\mathrm{P}$ value of the variable in multiple regressions. 
not affect its bioaccumulation. The concentrations of $\mathrm{Cu}$ in the tissues were in the range of 23 to $64 \mathrm{mg} \mathrm{kg}^{-1}$. The effect of these concentrations on the earthworm reproduction is discussed in detail below.

The normal range of $\mathrm{Cu}$ concentration in earthworm tissues can be determined through the use of biomarkers of the stress induced by this element. For example, Svendsen and Weeks (1997) used the stability of the lysosomal membrane as a biomarker of sub-cellular stress in the earthworms $E$. andrei exposed to increasing concentrations of $\mathrm{Cu}$. The degree of damage induced by $\mathrm{Cu}$ on the lysosomal membrane depended on its bioaccumulation. No damage to tissue was detected at concentrations of 8 to $25 \mathrm{mg} \mathrm{kg}^{-1}$. Concentrations of 25 to $55 \mathrm{mg} \mathrm{kg}^{-1}$ produced medium damage, while concentrations higher than 55 $\mathrm{mg} \mathrm{kg}{ }^{-1}$ provoked severe damage. Likewise, ScottFordsmand et al. (2000) reported the critical threshold of $50 \mathrm{mg} \mathrm{kg}-1$ of bioaccumulation of $\mathrm{Cu}$ by E. fetida, using the same biomarker of damage to the lysosomal membrane. Similarly, the species Lumbricus rubellus did not show a decrease in the production of cocoons with a $\mathrm{Cu}$ bioaccumulation below the critical threshold of $40 \mathrm{mg}$ $\mathrm{kg}^{-1}$ (Ma, 2005).

In the present study, the bioaccumulation of $23 \mathrm{mg} \mathrm{Cu}$ $\mathrm{kg}^{-1}$ in the earthworms present in the control soil can be considered as normal, in accordance with Svendsen and Weeks (1997). A higher bioaccumulation of $\mathrm{Cu}$ (in the range of 37 to $64 \mathrm{mg} \mathrm{kg}^{-1}$ ) caused a reduction in cocoon production. Svendsen and Weeks (1997) proposed that earthworms can present individual differences in the efficiency of excreting assimilated $\mathrm{Cu}$. Consequently, bioaccumulation of $\mathrm{Cu}$ is not a good biomarker of stress induced by this element, as is reflected in the low regression coefficient $\left(\mathrm{R}^{2}=0.37, \mathrm{P}<0.05\right)$ between the parameters of reproduction and bioaccumulation.

\section{CONCLUSIONS}

The majority of the studied soils in the Aconcagua River basin in Central Chile presented toxic effects on earthworms, inhibiting the production of cocoons and juveniles.

The regression analysis ruled out any evident effects of $\mathrm{Pb}, \mathrm{Zn}$, and As on the response of earthworms.

The observed effects on earthworm reproduction are mainly due to $\mathrm{Cu}$ and $\mathrm{OM}$, explaining $70 \%$ of the variance.

Reproduction of earthworms is not determined solely by $\mathrm{Cu}$, but also by $\mathrm{OM}$. It is necessary to know $\mathrm{OM}$ concentrations to correctly predict the response of macrofauna in soils contaminated by $\mathrm{Cu}$.

\section{ACKNOWLEDGEMENTS}

This study was funded by FONDECYT project 1050403. The authors are grateful to Marco Cisternas (Pontificia Universidad Católica de Valparaíso) for helpful comments.

\section{RESUMEN}

Materia orgánica reduce la toxicidad del cobre para la lombriz Eisenia fetida en suelos de áreas mineras en Chile Central. La cuenca del Río Aconcagua (Chile Central) es una de las más importantes áreas agrícolas en el país. Por otro lado, varias industrias de la minería de cobre $(\mathrm{Cu})$ se encuentran ubicadas en esta cuenca. El objetivo del estudio fue determinar la toxicidad de $\mathrm{Cu}$ para la lombriz Eisenia fetida (Savigny 1826) en los suelos agrícolas de la cuenca. Se determinó la producción de capullos y juveniles de la lombriz en suelos estudiados. Los suelos se diferenciaron por las concentraciones de materia orgánica (MO, rango 2-6\%), pH (rango 7,3-8,3), textura (entre arenoso franca y franco arcillosa) y concentraciones totales de $\mathrm{Cu}$ (rango 230-960 $\mathrm{mg} \mathrm{kg}^{-1}$ ). Las concentraciones de $\mathrm{Cu}$ y $\mathrm{MO}$ en los suelos fueron las variables que determinaron la respuesta biológica de las lombrices. En contraste, $\mathrm{pH}$ y textura no afectaron a esta respuesta. La producción de capullos y juveniles disminuyó considerablemente en suelos con altas concentraciones de $\mathrm{Cu}(>500 \mathrm{mg}$ $\mathrm{kg}^{-1}$ ), independientemente de las concentraciones de MO. La producción de capullos disminuyó en suelos con concentraciones de $\mathrm{Cu}$ inferiores a $500 \mathrm{mg} \mathrm{kg}^{-1}$ cuando las concentraciones de $\mathrm{MO}$ fueron inferiores a 3,5\%. Por el contrario, la producción de capullos no varió cuando la concentración de MO fue superior a 3,5\%. El mismo efecto de MO fue reconocido sobre la producción de juveniles. En este caso, el umbral crítico de la concentración de MO fue de $2,5 \%$. Se concluye la importancia de considerar las concentraciones de MO para predecir las respuestas biológicas de lombrices en estos suelos.

Palabras clave: Eisenia fetida, Río Aconcagua, evaluación del riesgo ecológico, minería de $\mathrm{Cu}$, elementos traza.

\section{LITERATURE CITED}

Davies, N.A., M.E. Hodson, and S. Black. 2003. Is the OECD acute worm toxicity test environmentally relevant? The effect of mineral form on calculated lead toxicity. Environ. Pollut. 121:49-54. 
De Gregori, I., E. Fuentes, M. Rojas, H. Pinochet, and M. Potin-Gautier. 2003. Monitoring of copper, arsenic and antimony levels in agricultural soils impacted and non-impacted by mining activities, from three regions in Chile. J. Environ. Monitor. 5:287-295.

Ginocchio, R., G. Carvallo, I. Toro, E. Bustamante, Y. Silva, and N. Sepulveda. 2004. Micro-spatial variation of soil metal pollution and plant recruitment near a copper smelter in Central Chile. Environ. Pollut. 127:343-352.

González, I., V. Muena, M. Cisternas, and A. Neaman. 2008. Acumulación de cobre en una comunidad vegetal afectada por contaminación minera en el valle de Puchuncaví, Chile Central. Rev. Chil. Hist. Nat. 81:279-291.

Hund-Rinke, K., M. Lindemann, and M. Simon. 2005. Experiences with novel approaches in earthworm testing alternatives. J. Soils Sediments 5:233-239.

Hund-Rinke, K., and H. Wiechering. 2001. Earthworm avoidance test for soil assessments. An alternative for acute and reproductive tests. J. Soils Sediments 1:1520.

Kabata-Pendias, A. 2004. Soil-plant transfer of trace elements: An environmental issue. Geoderma 122:143-149.

Kennette, D., W. Hendershot, A. Tomlin, and S. Sauvé. 2002. Uptake of trace metals by the earthworm Lumbricus terrestris L. in urban contaminated soil. Appl. Soil Ecol. 19:191-198.

Ma, W. 2005. Critical body residues (CBRs) for ecotoxicological soil quality assessment: copper in earthwors. Soil Biol. Biochem. 37:561-568.

Maxwell, J. 1968. Rock and mineral analysis. 584 p. Pergamon Press, Oxford, UK.

McBride, M., S. Sauvé, and W. Hendershot. 1997. Solubility control of $\mathrm{Cu}, \mathrm{Zn}, \mathrm{Cd}$ and $\mathrm{Pb}$ in contaminated soils. Eur. J. Soil Sci. 48:337-346.

Nahmani, J., M.E. Hodson, and S. Black. 2007a. Effects of metals on life cycle parameters of the earthworm Eisenia fetida exposed to field-contaminated, metalpolluted soils. Environ. Pollut. 149:44-58.

Nahmani, J., M.E. Hodson, and S. Black. 2007b. A review of studies performed to assess metal uptake by earthworms. Environ. Pollut. 145:402-424.

NRC. 2003. Bioavailability of contaminants in soils and sediments: Processes, tools and applications. 420 p. Commission on Bioavailability of Contaminants in Soils and Sediments. National Academy Press, Washington, D.C., USA.

OECD. 2000. Draft guideline for the testing of chemicals. 17 p. Earthworm reproduction test (Eisenia fetida/ andrei). Organization for Economic Cooperation and Development (OECD), Paris, France.
Posthuma, L., R. Baerselman, R.P.M. Van Veen, and E.M. Dirven-Van Breemen. 1997. Single and joint toxic effects of copper and zinc on reproduction of Enchytraeus crypticus in relation to sorption of metals in soils. Ecotox. Environ. Safe. 38:108-121.

Rachou, J., C. Gagnon, and S. Sauvé. 2007a. Use of an ion-selective electrode for free copper measurements in low salinity and low ionic strength matrices. Environ. Chem. 4:90-97.

Rachou, J., W. Hendershot, and S. Sauvé. 2007b. Soil organic matter impacts upon fluxes of cadmium in soils measured using diffusive gradients in thin films. Commun. Soil. Sci. Plant Anal. 38:1619-1636.

Sadzawka, A., M.A. Carrasco, R. Grez, G. Mora, H. Flores, y A. Neaman. 2006. Métodos de análisis recomendados para los suelos de Chile. Serie actas INIA $\mathrm{N}^{\circ}$ 34. 164 p. Instituto de Investigaciones Agropecuarias, Santiago, Chile.

Sauvé, S., A. Dumestre, M. McBride, and W. Hendershot. 1998. Derivation of soil quality criteria using predicted chemical speciation of $\mathrm{Pb}^{2+}$ and $\mathrm{Cu}^{2+}$. Environ. Toxicol. Chem. 17:1481-1489.

Sauvé, S., M.B. McBride, W.A. Norvell, W.H., and Hendershot. 1997. Copper solubility and speciation of in situ contaminated soils: Effects of copper level, $\mathrm{pH}$ and organic matter. Water Air Soil Pollut. 100:133149.

Scott-Fordsmand, J., J. Weeks, and S. Hopkin. 2000. Importance of the contamination history for understanding toxicity of copper to earthworm Eisenia fetida (Oligochaeta: Anelida), using neutralred retention assay. Environ. Toxicol. Chem. 19:17741780 .

Sheldrick, B.H., and C. Wang. 1993. Soil sampling and methods of analysis. p. 499-511. In M. Carter (ed.) Particle size distribution. Canadian Society of Soil Science, Lewis Publishers, Boca Raton, Florida, USA.

Slimak, K.M. 1997. Avoidance response as a sublethal effect of pesticides on Lumbricus terrestris (Oligochaeta). Soil Biol. Biochem. 29:713-715.

Spurgeon, D., and S. Hopkin. 1995. Extrapolation of laboratory based OECD earthworm test to metalcontaminated field sites. Ecotoxicology 4:190-205.

Spurgeon, D., and S. Hopkin. 1996. Effects of metalcontaminated soils on the growth, sexual development, and cocoon production of the earthworm Eisenia fetida, with particular reference to zinc. Ecotox. Environ. Safe. 35:86-95.

Spurgeon, D.J., and S.P. Hopkin. 1999. Comparisons of metal accumulation and excretion kinetics in earthworms (Eisenia fetida) exposed to contaminated field and laboratory soils. Appl. Soil Ecol. 11:227-243. 
Spurgeon, D., M. Weeks, and J. Van Gestel. 2003. A summary of eleven years progress in earthworm ecotoxicology. Pedobiologia 47:588-606.

Svendsen, C., and J.M. Weeks, 1997. Relevance and applicability of a simple earthworm biomarker of copper exposure. I. Links to ecotoxicological effects in a laboratory study with Eisenia andrei. Ecotox. Environ. Safe. 36:72-79.
Thakali, S., H. Allen, D. Di Toro, A. Ponizovsky, C. Rooney, F.J.Zhao, and S.P. McGrath. 2006. A terrestrial biotic ligand model. 1. Development and application to $\mathrm{Cu}$ and $\mathrm{Ni}$ toxicities to barley root elongation in soils. Environ. Sci. Technol. 40:7085-7093. 


\title{
GENE EXPRESSION ANALYSIS: A WAY TO STUDY TOLERANCE TO ABIOTIC STRESSES IN CROPS SPECIES
}

\author{
Eduardo Pérez-Torres ${ }^{1 *}$, Mario Paredes C. ${ }^{1}$, Víctor Polancoํㅜ, and Viviana Becerra B. ${ }^{1}$
}

\begin{abstract}
Regions traditionally destined to agriculture report an ever increasing exposure to cold and drought conditions. This is especially important in countries like Chile where crop management options are limited. The development of new cultivars with better yields under adverse conditions is fundamental if the ever increasing demand for food is to be matched; however, improving tolerance to abiotic stresses has proved to be a complex task. In this regard, development in plant physiology and genomics in the last 20 years has led to a deeper understanding of how plants respond to stress and mechanisms responsible for different ranges of tolerance observed in nature. This review discusses the techniques currently most in use in gene expression analysis, together with some important experimental design variables, such as the developmental stage of the plant, stress intensity and duration, and how different stresses may interact when performing assays. On the other hand, it is fundamental to properly select gene expression techniques according to the available information on the genome, the crop and the final objective of the research. All these points must be considered to ease transition from genomics to practical applications to crop species in order to increase their tolerance to stress. In this regard, the rapid development of new techniques in gene expression analysis with lower costs will determine a new revolution in crop research in coming decades. Therefore, Chile needs to be prepared in this area to continue its development as a major food producer worldwide.
\end{abstract}

Key words: cold, drought, crops species, gene expression.

\section{INTRODUCTION}

Episodes of low or high temperature and drought are among the environmental conditions that most plants experience on a daily basis. In crops, this variation from ideal growth conditions often results in lower yields and a high economic impact for producers and consumers.

Understanding the mechanisms involved in the response of plants to adverse environmental conditions is, without a doubt, the first step in the generation of crops with higher tolerance to stress. Research at the level of genes (genomics), proteins (proteomics), metabolites (metabolomics), individuals (physiology, systemic- biology) and communities (ecology) has been fundamental in the current understanding of the response of plants to stress. In particular, a huge development in the field of genomics in the last 20 years has led to a deeper understanding in areas such as gene expression, organization and its relationship to stress tolerance. Functional genomics studies the function of genes of an organism and focuses

${ }^{1}$ Instituto de Investigaciones Agropecuarias, Centro Regional de Investigación Quilamapu, Casilla 426, Chillán, Chile.

*Corresponding author (eperez@inia.cl).

Received: 12 May 2008.

Accepted: 14 August2008. on dynamic processes such as transcription, translation, interaction of genes and how they are related to different phenotypes. Connecting gene function and traits relevant to agriculture, such as yield, plant structure and tolerance to adverse environmental conditions has become of utmost interest considering global warming, urban development and an ever increasing population demand for food.

Genome analysis has been mostly limited to model plants that fulfil some specific requirements such as: (1) small genome size, (2) short generation time, (3) small size to enable growth in limited space, and (4) availability of gene manipulation technologies (Tabata, 2002). In particular, two of the most important model species are Arabidopsis thaliana and rice (Oryza sativa L.) for dicotyledonous and monocotyledoneous plant species, respectively. Besides its importance as a crop, rice has a high degree of synteny with genomes of other cereals plants, such as maize, wheat, barley and other grasses because their genomes share a considerable similarity in their organization, as well as sequence similarity (Gale and Devos, 1998; Bowers et al., 2005; Paterson et al., 2005). Great advances in the comparison of genomes and transcriptomes of different organisms have contributed to the development of comparative genomics as one of the most promising fields in the area (Gale and Devos, 1998; 
Caicedo and Purugganan, 2005). In this way, finding variations in the genome or the transcriptome from the current model species related to interesting agronomic traits is of the highest importance for crop biotechnology (van de Mortel and Aarts, 2006).

The objective of this review is to summarize current techniques used in gene expression analysis in plants and their relevance to abiotic stress research. Special emphasis is given to issues to be considered when comparing performance of crops in controlled conditions and in the field.

\section{Techniques used for evaluating gene expression in functional genomics studies}

A fundamental step in any functional genomics study is the analysis of gene expression. One of the greatest strengths of genomics compared to other disciplines is the prospect of analyzing the expression of thousands of genes simultaneously, resulting in a more comprehensive picture of changes occurring in the transcriptome across different conditions (Green et al., 2001).

The technology available for the analysis of gene expression can be divided into two categories: closed and open systems (Table 1). Closed systems are characterized by a finite number of genes that can be assessed by virtue of their inclusion by selection. Therefore, the coverage of genes will be related to the completeness of the knowledge of the genome being studied, limiting this kind of analysis to the most well characterized species or systems (Green et al., 2001). Typically, closed systems such as microarrays (Table 2) and real-time polymerase chain reaction (PCR) have been extensively used in gene expression analysis in plants (Ma et al., 2005; Rensink et al., 2005; Oono et al., 2006; Xu and Shi, 2006; Mantri et al., 2007; Monroy et al., 2007; Fernandez et al., 2008; Remans et al., 2008). On the other hand, with open systems there is no need for previous knowledge of the genome or transcriptome of the organism. cDNA-AFLP (cDNA-Amplified fragment length polymorphism), MPSS (massively parallel signature sequencing), and specially SAGE (serial analysis of gene expression) have been successfully used to quantify transcript abundance and generate expression data across different tissue types or developmental stages in higher plants ( Fizames et al., 2004; Meyers et al., 2004; Calsa and Figueira, 2007; Chen et al., 2007; Leymarie et al., 2007; McIntosh et al., 2007; Song et al., 2007; Ritter et al., 2008). Worth mentioning are 454-sequencing technology and digital gene expression (DGE) that have recently been used to study the transcriptome of different organisms and promise to become an efficient and costeffective alternative with high potential in crop research (Mikkilineni et al., 2004; Margulies et al., 2005; Velculescu and Kinzler, 2007; Weber et al., 2007; Torres et al., 2008). Open and closed systems should not be considered as competitors, but rather as complementary technologies to

\section{Table 1. Most commonly used techniques for gene expression analysis in plants.}

cDNA-AFLP. RNA is converted into double stranded cDNA and then digested with two restriction enzymes: a frequent-cutter and a rare-cutter. Synthetic adapters are ligated to the cDNA ends and primers complementary to the adapter sequences (plus small extensions of 1, 2, or 3 nucleotides) are used to amplify fragments with asymmetric ends. These fragments are displayed on sequencing gels and compared. Specific fragments can be eluted from gels and sequenced to identify genes with differential expression (Bachem et al., 1996).

SAGE. RNA is converted to double-stranded cDNA with a biotin attached to the oligo(dT) first strand synthesis primer and cleaved with a restriction enzyme, leaving 3'-most fragments immobilized onto streptavidin beads. After ligation with linkers onto the non-biotinylated end cDNAs are released, ligated together and amplified by PCR. Primer regions are removed from PCR products and the resulting fragments are ligated together into concatemers, cloned and sequenced. Finally, a software package identifies and counts the relative frequency of the sequences in the samples (Velculescu et al., 1995; Yamamoto et al., 2001).

MPSS. Individual 3' restriction fragments from a cDNA library are coupled to one of a million beads, amplified, arrayed and sequenced simultaneously for 20 residues to provide a million signature sequences. Transcripts can then be identified and the corresponding transcriptome quantitatively characterized (Brenner et al., 2000).

Microarrays. Marked samples are tested against sequences from thousands of different genes fixed on small solid supports (usually glass microscope slides). Depending on their sequence, the samples will hybridize with different spots in the array, which is analyzed by specialized image software (Schena et al., 1995).

Real-time PCR. A variant from conventional PCR based on the detection and quantification of the fluorescence emitted by PCR products accumulated through the amplification process (Higuchi et al., 1993). 
be used depending on the subject to be analyzed and the objectives of the research.

The amount of material available is an important variable to be considered in the selection of a technology for gene expression analysis. In particular, the sensitivity and coverage of the method will be determinant considering that $90-95 \%$ of all mRNA species are present at five or fewer copies per cell (Green et al., 2001). When insufficient quantities of RNA are obtained, cDNA generated from RNA can be amplified exponentially by PCR, or linearly with T7 RNA polymerase to avoid differential amplification (Brady et al., 2006).

Another variable to keep in mind is the selection of the sample to be analyzed. In this regard, the latest advances in microdissection techniques allow extraction of RNA from specific tissues and individual cells, opening the possibility of a highly detailed analysis and a considerable reduction of noise generated by the natural heterogeneity of plant organs (Brandt, 2005; Lee et al., 2005; Ohtsu et al., 2007).

\section{Abiotic stress variables to be considered in functional genomics studies}

The aim of most functional genomics studies concerned with abiotic stress is to relate gene function to traits of plant performance under adverse environmental conditions.
A recurring question is how representative are growth chamber studies compared to field studies. In this respect there is a lack of studies that comprehensively evaluate correlations between growth chambers and the field in terms of plant performance. The issues in what follows should be considered when designing an experiment in controlled conditions with possible applications in the field:

Combination of stresses. Most studies so far have been focused on the response to just one kind of stress. This strategy has led to key discoveries that otherwise would not have been possible and that have helped us to understand in greater depth the way plants respond to stress. However, it should be noted that plants in the field are usually exposed to more than one stress simultaneously. This combination of stresses is fundamental to understand differences between the performance of crops in controlled growth chambers and in the field (Knight and Knight, 2001; Mittler, 2006).

Length of the treatment. Despite the fact that valuable data can be obtained from short term experiments, it is longer term plant performance with respect to biomass, yield data and the degree of recovery from stress that has the most value in agriculture (Vinocur and Altman, 2005).

Table 2. Gene expression analysis through microarrays in some crops.

\begin{tabular}{|c|c|c|}
\hline Plant & Stress & Reference \\
\hline Capsicum annuит & Cold stress & Hwang et al., 2005 \\
\hline Hordeum vulgare & Drought and salinity & Ozturk et al., 2002 \\
\hline \multirow[t]{6}{*}{ Oryza sativa } & Cold, drought, salinity and $\mathrm{ABA}^{1}$ treatment & Rabbani et al., 2003 \\
\hline & Chilling stress & Yamaguchi et al., 2004 \\
\hline & Drought stress & Hazen et al., 2005 \\
\hline & Drought stress & Lan et al., 2005 \\
\hline & Drought stress & Wang et al., 2007 \\
\hline & Drought and high salinity & Zhou et al., 2007 \\
\hline Solanum tuberosum & Cold, heat and salt stress & Rensink et al., 2005 \\
\hline Sorghum bicolor & Dehydration, salt and ABA treatment & Buchanan et al., 2005 \\
\hline \multirow[t]{2}{*}{ Triticum aestivum } & Low-temperature stress & Gulick et al., 2005 \\
\hline & Drought & Mohammadi et al., 2007 \\
\hline Helianthus annuus & Chilling stress & Fernandez et al., 2008 \\
\hline Zea mays & Salinity & Wang et al., 2003 \\
\hline Manihot esculenta & Heat and drought & Sakurai et al., 2007 \\
\hline
\end{tabular}

\footnotetext{
${ }^{1}$ ABA: amino butyric acid.
} 
Intensity of the treatment. Plants respond in different manners to variable degrees of stress, as different protection/repair mechanisms will be engaged accordingly. For example, the response of a plant to chilling stress will be different from the response to freezing stress, considering that the latter can lead to ice formation. The intensity of the treatment will also be of the utmost importance for screening purposes, especially when a ranking of tolerance to stress is to be established.

Stage of crop development. Clearly, tolerance to stress is different throughout the lifecycle of any plant and the consequences of exposure to stress may also vary. As an example, rice is especially susceptible to low temperature during the germination and reproductive stages (Board et al., 1980; Jacobs and Pearson, 1994) In the first, a possible consequence is the failure to germinate. Exposure to cold during the reproductive stage will induce sterility rather than have an effect on plant survival. In this regard, it is important to have plants in similar stages of development when screening for tolerance to stress, especially with cultivars that complete their lifecycle at different times.

Designing experiments in functional crop genomics must consider all these recommendations in order to successfully extrapolate results to the field. As well, it is important to keep in mind genotype $\mathrm{x}$ environment interactions ( $\mathrm{G} \times \mathrm{E}$ ) when evaluating the performance of any genotype in the field by including the range of adaptation of new varieties to different environments and the consistency of their performance over time. In order to effectively recognize $\mathrm{G} \times \mathrm{E}$ in any breeding program, there must be a comprehensive characterization of the genotypes and environments being assayed, and these considerations are valid for genomics as well.

\section{Functional genomics and stress response in crops}

Abiotic stresses are estimated to reduce yield to less than half compared to the potential under ideal growing conditions (Boyer, 1982). Unlike plant resistance to biotic stresses, which is mostly monogenic, tolerance to abiotic stresses are generally multigenic, quantitative and complex traits controlled by quantitative trait loci (QTL). This has clear consequences for the development of plants that are more tolerant to abiotic stresses by genetic engineering (Vinocur and Altman, 2005). A further complication is that some genes may exert control over different traits, resulting in unwanted changes in agronomic plant traits.

Cold and drought tolerance in crops constitute highly desired traits in Chile given the economic consequences of the current climatic trend of very low temperatures in winters and severe drought in summers. Cold stress in plants causes a reduction in enzyme activities, reaction rates, energy imbalance and is accompanied by changes in the transcriptome, proteome and metabolome (Guy et al., 2008). On the other hand, when plants are exposed to drought, there is a characteristic response of a partialto-total stomatal closure, resulting in a reduction of $\mathrm{CO}_{2}$ uptake, transpiration and a major impact for photosynthesis and source-sink relationships (Chaves et al., 2002).

The consequences of any stress will depend on its intensity. As an example, chilling temperatures will be responsible for lower metabolic rates and energy imbalance, while freezing temperatures will additionally cause membrane injury and severe dehydration when ice forms (Graham and Patterson, 1982; Thomashow, 1998; Pearce, 2001).

Drought and temperature stress might occur alone or in combination at any stage in plant development, causing reduced grain weight and yield loss (Sreenivasulu et al., 2007). It is known that exposure to one kind of stress usually involves an increased tolerance to other stresses given that similar effects are shared at the cellular level. As an example, freezing temperatures, low water availability and high salinity can all cause lowering of the cellular osmotic potential and thereby activate osmotic stress responses (Langridge et al., 2006). In this regard, it is not unexpected to find promoters that have sequences for transcription factors involved in drought, salt and cold response, suggesting points of convergence at the molecular level (Knight and Knight, 2001). These results, added to a high overlapping of genes involved in the response to cold, drought and high salinity, suggest an intricate coordination of the response to multiple stresses in plants at molecular level (Kreps et al., 2002; Seki et al., 2002; Seki et al., 2004; Matsui et al., 2008).

At first glance, a shared regulatory network involved in the response to multiple stresses opens possibilities for the development of multiple-stress-tolerant plants. However, it must not be forgotten that the combination of some stresses might require conflicting or antagonistic responses. In this way, the acclimation of plants to this combination would require an appropriate response to each individual stress, as well as compensation and adjustment for some of the antagonistic aspects involved (Mittler, 2006; Rizhsky et al., 2004). As an example, when plants are exposed to drought, their stomata are closed, which is clearly an antagonistic response if the plant is simultaneously exposed to heat, when transpiration is necessary to reduce leaf temperature.

Higher tolerance to abiotic stress could be achieved by increasing protective mechanisms (antioxidants, nonphotochemical quenching, etc.) or by increasing the capacity to repair the damage caused by stress. In this matter, the capacity of recovery from stress is usually overlooked, despite its relevance considering that cycles of stress and recovery are common under natural 
conditions and may have a major impact in yield (Vinocur and Altman, 2005).

In model species, such as Arabidopsis, more than $40-50 \%$ of identified stress-responsive gene functions remains to be characterized (Sreenivasulu et al., 2007). In this regard, a successful approach in determining gene function comes from sequence comparison with databases and, more recently, the use of coexpression modules with promising results (Subramanian et al., 2005).

Comparative genomics constitute an increasingly important field in order to understand how similar model species and crops are, and how to transfer knowledge obtained from model species to applications in agriculture (Paterson et al., 2005; van de Mortel and Aarts, 2006). In this matter, the choice of putative candidate genes is facilitated by the conservation of gene sequences, order and distribution among species and the existence of similar functional gene categories in morphologically similar organs (Brady et al., 2006; Pflieger et al., 2001).

Changes in the transcriptome among related species under stress reported by different groups are usually hard to compare since treatments are usually performed with different tissues, exposure times, intensities, and using different technologies. In this way, a careful experimental design with related plants that present different degrees of tolerance to stress can be extremely informative. A successful example is the comparison of the transcriptome of winter and spring wheat, cultivars with different tolerance to cold, exposed to low temperature. This study reports the correlation of gene expression kinetics with tolerance to low temperature, a subject usually overlooked that emphasizes the importance of sampling in functional genomics studies (Gulick et al., 2005; Monroy et al., 2007).

Gene expression profiling has allowed the identification of hundreds of genes induced when plants are exposed to stress ( Kreps et al., 2002; Oono et al., 2006; Jianping and Suleiman, 2007; Mantri et al., 2007). The availability of the complete genome sequence of some model plants, such as $O$. sativa and $A$. thaliana, has allowed the development of whole genome tiling microarrays. This constitutes a new powerful technology that has already made possible the identification of several unannotated transcripts responsive to abiotic stress (Gregory et al., 2008; Matsui et al., 2008). However, finding a gene responsive to stress does not necessarily guarantee its participation in

Table 3. Maize and rice transgenics and stress tolerance.

\begin{tabular}{|c|c|c|c|}
\hline Plant & Gene & Result & Reference \\
\hline \multirow[t]{4}{*}{ Maize } & NPK1 (tobacco MAPKKK) & Drought and freezing tolerance & Shou et al., 2004 \\
\hline & ZmNF-YB2 (maize nuclear factor YB2) & Drought tolerance & Nelson et al., 2007 \\
\hline & ZmPLC1 (phospholipase C 1) & Drought tolerance & Wang et al., 2008 \\
\hline & TsVP (vacuolar-H+-pyrophosphatase) & Drought tolerance & Li et al., 2008 \\
\hline \multirow[t]{14}{*}{ Rice } & HVA1 (Barley group 3 LEA protein) & Drought and salt tolerance & Xu et al., 1996 \\
\hline & GPAT (Arabidopsis glycerol-3P-acyltransferase) & Chilling tolerance & Yokoi et al., 1998 \\
\hline & OsCDPK7 (rice calcium-dependent protein kinase) & $\begin{array}{l}\text { Cold, drought and salt } \\
\text { tolerance }\end{array}$ & Saijo et al., 2000 \\
\hline & Dadc (D. stramonium arginine decarboxylase) & Drought tolerance & Capell et al., 2004 \\
\hline & ABF3 (Arabidopsis ABRE-binding factor 3) & Drought tolerance & Oh et al., 2005 \\
\hline & DREB1A (Arabidopsis DRE-binding protein 1) & Drought and salt tolerance & Oh et al., 2005 \\
\hline & MnSOD (pea Mn superoxide dismutase) & Drought tolerance & Wang et al., 2005 \\
\hline & SNAC1 (rice stress responsive NAC1) & Drought and salt tolerance & Hu et al., 2006 \\
\hline & OsDREB1 (rice DRE-binding protein 1) & $\begin{array}{l}\text { Drought, salt and cold stress } \\
\text { tolerance }\end{array}$ & Ito et al., 2006 \\
\hline & $\mathrm{HvCBF4}$ (barley C-repeat binding factor) & $\begin{array}{l}\text { Drought, salt and cold stress } \\
\text { tolerance }\end{array}$ & Oh et al., 2007 \\
\hline & $\begin{array}{l}\text { OsCIPK03 (rice calcineurin B-like protein- } \\
\text { interacting protein kinase } 03 \text { ) }\end{array}$ & Cold tolerance & Xiang et al., 2007 \\
\hline & $\begin{array}{l}\text { OsCIPK12 (rice calcineurin B-like protein- } \\
\text { interacting protein kinase 12) }\end{array}$ & Drought tolerance & Xiang et al., 2007 \\
\hline & OsTPP1 (trehalose-6-phosphate phosphatase) & Salinity and cold tolerance & Ge et al., 2008 \\
\hline & ZFP252 (rice TFIIIA-type zinc finger protein) & Drought and salt tolerance & Xu et al., 2008 \\
\hline
\end{tabular}


tolerance to this condition. Identification and sequencing allow assigning a putative function to a sequence when a significant homology with genes of known function is found. These results are then usually complemented with a proper validation by the use of transgenics. This approach has been especially important in the discovery of several candidate genes in crops in the last decade and, in some cases, it has led to significant improvements in tolerance to stress (Table 3). As an example, the relevance of membrane lipids in tolerance to cold was shown in rice transformed with Arabidopsis glycerol3P-acyltransferase (GPAT) that increased the levels of unsaturated fatty acids in the phosphatidylglycerol by $28 \%$ and resulted in a $20 \%$ increase in the photosynthetic rates at $17^{\circ} \mathrm{C}$ (Yokoi et al., 1998). An example showing the importance of transcription factors in the response to stress was observed in transgenic rice for the transcription factor ABF3 (Arabidopsis ABRE-binding factor 3), which showed increased tolerance to drought (Oh et al., 2005).

It is also interesting that different responses are obtained by manipulation of genes within the same family. A good example are calcineurin B-like protein-interacting protein kinases: OsCIPK03, OsCIPK12, and OsCIPK15, whose over-expression in japonica rice Zhonghua, led to specific improved tolerance to cold, drought, and salt stress respectively (Xiang et al., 2007). These results demonstrate the participation of single genes in tolerance to a particular stress. However, it has also been shown that manipulation of single genes can lead to increased tolerance to more than one kind of stress. As an example, the constitutive expression of the transcription factor DREB1A (Arabidopsis DRE-binding protein 1) in rice determined increased tolerance to drought and salt stress. Interestingly, when OsDREB1 (rice DRE-binding protein 1) was over-expressed in rice it resulted in increased tolerance for drought, salt and cold stress (Ito et al., 2006). Similar multi-tolerance effects were observed by over-expressing genes such as OsCDPK7, a calciumdependent protein kinase, which resulted in rice with increased tolerance to cold, salt and drought stress (Saijo et al., 2000). Manipulation of genes with roles other than regulation, such as detoxification, protection and osmotic regulation, has also resulted in increased tolerance to stress in plants (Xu et al., 1996; Capell et al., 2004; Ge et al., 2008; Li et al., 2008; Wang et al., 2008). Targeting effector, rather than regulatory genes, may result in fewer side effects considering the unwanted activation of responsive genes involved in other metabolic pathways.

Despite similarities among different plants, it must not be forgotten that species such as wheat and barley, with far less characterized genomes compared to model plants, may offer unique and interesting features. Their high level of abiotic tolerance and diversity may provide important resources for validation of candidate genes and accelerate important breeding programs (Langridge et al., 2006). Performance in the field of these species suggests that greater tolerance to abiotic stress is still achievable for other crops if proper research is conducted and should stimulate the exploration of new technologies and alliances between scientists and farmers.

\section{CONCLUSIONS}

Gene expression profiling constitutes an exciting tool to unveil mechanisms involved in the response of plants to environmental stress. Its application in crop research is just starting as technologies are becoming more accessible and cost-effective and are expected to fuel huge advances in agriculture in the coming decades. Currently, the importance of biotechnology is being acknowledged by breeding programs around the world and is resulting in the development of new techniques and approaches to increase crop tolerance to stress. Whether Chile will continue to increase its share in the food market worldwide will depend on its ability to develop sustainable and cutting-edge crop research in the future.

\section{RESUMEN}

Análisis de la expresión génica: Una forma de estudiar la tolerancia a estreses abióticos en cultivos. Las regiones agrícolas están cada vez más expuestas a condiciones de frío y sequía, algo especialmente importante en países con opciones limitadas de manejo de cultivos como Chile. Si la creciente demanda por alimento ha de ser cubierta, es necesaria la compleja tarea del desarrollo de nuevos cultivares con mejores rendimientos bajo condiciones de estrés. El desarrollo de la fisiología vegetal y la genómica en los últimos 20 años ha permitido entender mejor cómo las plantas responden al estrés y los mecanismos responsables de los distintos rangos de tolerancia observados en la naturaleza. En esta revisión, se discuten las técnicas más usadas actualmente en análisis de expresión génica $\mathrm{y}$ algunas variables que deben ser consideradas en el diseño experimental tales como el estado de desarrollo de la planta y la intensidad, duración e interacción de distintos tipos de estrés, además de la elección de técnicas apropiadas de acuerdo a la información disponible del genoma del cultivo y el objetivo final de la investigación. Todos estos puntos son fundamentales para facilitar la transición desde la genómica a aplicaciones prácticas en el aumento de la tolerancia al estrés de los cultivos. En este sentido, el rápido desarrollo de nuevas técnicas para estudiar la expresión de genes a menor costo determinará una nueva revolución en la investigación de cultivos en 
las próximas décadas. En este sentido, Chile necesita estar preparado en esta área para continuar su desarrollo como un importante productor de alimentos a nivel mundial.

Palabras clave: frío, sequía, cultivos, expresión génica.

\section{LITERATURE CITED}

Bachem, C.W.B., R.S. van der Hoeven, S.M. de Bruijn, D. Vreugdenhil, M. Zabeau, and R.G.F. Visser. 1996. Visualization of differential gene expression using a novel method of RNA fingerprinting based on AFLP: Analysis of gene expression during potato tuber development. Plant J. 9:745-753.

Board, J.E., M.L. Peterson, and E. Ng. 1980. Floret sterility in rice in a cool environment. Agron. J. 72:483-487.

Bowers, J.E., M.A. Arias, R. Asher, J.A. Avise, R.T. Ball, G.A. Brewer, et al. 2005. Comparative physical mapping links conservation of microsynteny to chromosome structure and recombination in grasses. Proc. Natl. Acad. Sci. USA. 102:13206-13211.

Boyer, J. 1982. Plant productivity and environment. Science 218:443-448.

Brady, S.M., T.A. Long, and P.N. Benfey. 2006. Unraveling the dynamic transcriptome. Plant Cell 18:2101-2111.

Brandt, S.P. 2005. Microgenomics: gene expression analysis at the tissue-specific and single-cell levels. J. Exp. Bot. 56:495-505.

Brenner, S., M. Johnson, J. Bridgham, G. Golda, D.H. Lloyd, D. Johnson, et al. 2000. Gene expression analysis by massively parallel signature sequencing (MPSS) on microbead arrays. Nat. Biotechnol. 18:630-634.

Buchanan, C.D., S. Lim, R.A. Salzman, I. Kagiampakis, D.T. Morishige, B.D. Weers, et al. 2005. Sorghum bicolor's transcriptome response to dehydration, high salinity and ABA. Plant Mol. Biol. 58:699-720.

Caicedo, A.L., and M.D. Purugganan. 2005. Comparative plant genomics. Frontiers and prospects. Plant Physiol. 138:545-547.

Calsa, T., and A. Figueira. 2007. Serial analysis of gene expression in sugarcane (Saccharum spp.) leaves revealed alternative C4 metabolism and putative antisense transcripts. Plant Mol. Biol. 63:745-762.

Capell, T., L. Bassie, and P. Christou. 2004. Modulation of the polyamine biosynthetic pathway in transgenic rice confers tolerance to drought stress. Proc. Natl. Acad. Sci. USA. 101:9909-9914.

Chaves, M.M., J.S. Pereira, J. Maroco, M.L. Rodrigues, C.P.P. Ricardo, M.L. Osorio, et al. 2002. How plants cope with water stress in the field? Photosynthesis and growth. Ann. Bot. London 89:907-916.
Chen, J., V. Agrawal, M. Rattray, M. West, D. St Clair, R. Michelmore, et al. 2007. A comparison of microarray and MPSS technology platforms for expression analysis of Arabidopsis. BMC Genomics 8:414.

Fernandez, P., J.D. Rienzo, L. Fernandez, H.E. Hopp, N. Paniego, and R.A. Heinz. 2008. Transcriptomic identification of candidate genes involved in sunflower responses to chilling and salt stresses based on cDNA microarray analysis. BMC Plant Biol. 8:11.

Fizames, C., S. Munos, C. Cazettes, P. Nacry, J. Boucherez, F. Gaymard, et al. 2004. The arabidopsis root transcriptome by serial analysis of gene expression. Gene identification using the genome sequence. Plant Physiol. 134:67-80.

Gale, M.D., and K.M. Devos. 1998. Comparative genetics in the grasses. Proc. Natl. Acad. Sci. USA. 95:19711974.

Ge, L.-F., D.-Y. Chao, M. Shi, M.-Z. Zhu, J.-P. Gao, and H.-X. Lin. 2008. Overexpression of the trehalose-6phosphate phosphatase gene OsTPP1 confers stress tolerance in rice and results in the activation of stress responsive genes. Planta 228:191-201.

Graham, D., and B.D. Patterson. 1982. Responses of Plants to low, nonfreezing temperatures: proteins, metabolism, and acclimation. Annu. Rev. Plant Physiol. Plant Mol. Biol. 33:347-372.

Green, C.D., J.F. Simons, B.E. Taillon, and D.A. Lewin. 2001. Open systems: panoramic views of gene expression. J. Immunol. Methods 250:67-79.

Gregory, B.D., J. Yazaki, and J.R. Ecker. 2008. Utilizing tiling microarrays for whole-genome analysis in plants. Plant J. 53:636-644.

Gulick, P.J., S. Drouin, Z. Yu, J. Danyluk, G. Poisson, A.F. Monroy, and F. Sarhan. 2005. Transcriptome comparison of winter and spring wheat responding to low temperature. Genome 48:913-923.

Guy, C., F. Kaplan, J. Kopka, J. Selbig, and D.K. Hincha. 2008. Metabolomics of temperature stress. Physiol. Plant 132:220-235.

Hazen, S.P., M.S. Pathan, A. Sanchez, I. Baxter, M. Dunn, B. Estes, et al. 2005. Expression profiling of rice segregating for drought tolerance QTLs using a rice genome array. Funct. Integr. Genomics 5:104-116.

Higuchi, R., C. Fockler, G. Dollinger, and R. Watson. 1993. Kinetic PCR analysis: Real-time monitoring of DNA amplification reactions. Nat. Biotechnol. 11:1026-1030.

Hu, H., M. Dai, J. Yao, B. Xiao, X. Li, Q. Zhang, and L. Xiong. 2006. Overexpressing a NAM, ATAF, and CUC (NAC) transcription factor enhances drought resistance and salt tolerance in rice. Proc. Natl. Acad. Sci. USA. 103:12987-12992. 
Hwang, E.-W., K.-A. Kim, S.-C. Park, M.-J. Jeong, M.O. Byun, and H.-B. Kwon. 2005. Expression profiles of hot pepper (Capsicum annuum) genes under cold stress conditions. J. Biosci. 30:657-667.

Ito, Y., K. Katsura, K. Maruyama, T. Taji, M. Kobayashi, M. Seki, et al. 2006. Functional analysis of rice DREB1/CBF-type transcription factors involved in cold-responsive gene expression in transgenic rice. Plant Cell Physiol. 47:141-153.

Jacobs, B.C., and C.J. Pearson. 1994. Cold damage and development of rice: a conceptual model. Aust. J. Exp. Agric. 34:917-919.

Jianping, P.W., and S.B. Suleiman. 2007. Monitoring of gene expression profiles and identification of candidate genes involved in drought responses in Festuca mairei. Mol. Genet. Genomics 277:571-587.

Knight, H., and M.R. Knight. 2001. Abiotic stress signalling pathways: specificity and cross-talk. Trends Plant Sci. 6:262-7.

Kreps, J.A., Y. Wu, H.-S. Chang, T. Zhu, X. Wang, and J.F. Harper. 2002. Transcriptome changes for arabidopsis in response to salt, osmotic, and cold stress. Plant Physiol. 130:2129-2141.

Lan, L., M. Li, Y. Lai, W. Xu, Z. Kong, K. Ying, et al. 2005. Microarray analysis reveals similarities and variations in genetic programs controlling pollination/ fertilization and stress responses in rice (Oryza sativa L.). Plant Mol. Biol. 59:151-164.

Langridge, P., N. Paltridge, and G. Fincher. 2006. Functional genomics of abiotic stress tolerance in cereals. Brief. Funct. Genomics Proteomics 4:343354.

Lee, J.-Y., M. Levesque, and P.N. Benfey. 2005. Highthroughput RNA isolation technologies. New tools for high-resolution gene expression profiling in plant systems. Plant Physiol. 138:585-590.

Leymarie, J., E. Bruneaux, S. Gibot-Leclerc, and F. Corbineau. 2007. Identification of transcripts potentially involved in barley seed germination and dormancy using cDNA-AFLP. J. Exp. Bot. 58:425-437.

Li, B., A. We, C. Song, N. Li, and J. Zhang. 2008. Heterologous expression of the TsVP gene improves the drought resistance of maize. Plant Biotech. J. 6:146-159.

Ma, L., C. Chen, X. Liu, Y. Jiao, N. Su, L. Li, et al. 2005. A microarray analysis of the rice transcriptome and its comparison to arabidopsis. Genome Res. 15:12741283.

Mantri, N., R. Ford, T. Coram, and E. Pang. 2007. Transcriptional profiling of chickpea genes differentially regulated in response to high-salinity, cold and drought. BMC Genomics 8:303.
Margulies, M., M. Egholm, W.E. Altman, S. Attiya, J.S. Bader, L.A. Bemben, et al. 2005. Genome sequencing in microfabricated high-density picolitre reactors. Nature 437:376-380.

Matsui, A., J. Ishida, T. Morosawa, Y. Mochizuki, E. Kaminuma, T.A. Endo, et al. 2008. Arabidopsis transcriptome analysis under drought, cold, highsalinity and ABA treatment conditions using a tiling array. Plant Cell Physiol. 49:1135-1149.

McIntosh, S., L. Watson, P. Bundock, A. Crawford, J. White, G. Cordeiro, D. Barbary, L. Rooke, and R. Henry. 2007. SAGE of the developing wheat caryopsis. Plant Biotechnol. J. 5:69-83.

Meyers, B.C., S.S. Tej, T.H. Vu, C.D. Haudenschild, V. Agrawal, S.B. Edberg, et al. 2004. The use of MPSS for whole-genome transcriptional analysis in arabidopsis. Genome Res. 14:1641-1653.

Mikkilineni, V., R.D. Mitra, J. Merritt, J.R. DiTonno, G.M. Church, B. Ogunnaike, and J.S. Edwards. 2004. Digital quantitative measurements of gene expression. Biotechnol. Bioeng. 86:117-124.

Mittler, R. 2006. Abiotic stress, the field environment and stress combination. Trends Plant Sci. 11:15-19.

Mohammadi, M., N.N.V. Kav, and M.K. Deyholos. 2007. Transcriptional profiling of hexaploid wheat (Triticum aestivum L.) roots identifies novel, dehydrationresponsive genes. Plant Cell Environ. 30:630-645.

Monroy, A., A. Dryanova, B. Malette, D. Oren, M. Ridha Farajalla, W. Liu, et al. 2007. Regulatory gene candidates and gene expression analysis of cold acclimation in winter and spring wheat. Plant Mol. Biol. 64:409-423.

Nelson, D.E., P.P. Repetti, T.R. Adams, R.A. Creelman, J. Wu, D.C. Warner, et al. 2007. Plant nuclear factor Y (NF-Y) B subunits confer drought tolerance and lead to improved corn yields on water-limited acres. Proc. Natl. Acad. Sci. USA. 104:16450-16455.

Oh, S.-J., C.-W. Kwon, D.-W. Choi, S.I. Song, and J.-K. Kim, 2007. Expression of barley HvCBF4 enhances tolerance to abiotic stress in transgenic rice. Plant Biotechnol. J. 5:646-656.

Oh, S.-J., S.I. Song, Y.S. Kim, H.-J. Jang, S.Y. Kim, M. Kim, et al. 2005. Arabidopsis CBF3/DREB1A and $\mathrm{ABF} 3$ in transgenic rice increased tolerance to abiotic stress without stunting growth. Plant Physiol. 138:341-351.

Ohtsu, K., H. Takahashi, P.S. Schnable, and M. Nakazono. 2007. Cell type-specific gene expression profiling in plants by using a combination of laser microdissection and high-throughput technologies. Plant Cell Physiol. 48:3-7. 
Oono, Y., M. Seki, M. Satou, K. Iida, K. Akiyama, T. Sakurai, et al. 2006. Monitoring expression profiles of Arabidopsis genes during cold acclimation and deacclimation using DNA microarrays. Funct. Integr. Genomics 6:212-234.

Ozturk, Z.N., V. Talamé, M. Deyholos, C.B. Michalowski, D.W. Galbraith, N. Gozukirmizi, et al. 2002. Monitoring large-scale changes in transcript abundance in drought- and salt-stressed barley. Plant Mol. Biol. 48:551-573.

Paterson, A.H., M. Freeling, and T. Sasaki. 2005. Grains of knowledge: Genomics of model cereals. Genome Res. 15:1643-1650.

Pearce, R.S. 2001. Plant freezing and damage. Ann. Bot. 87:417-424.

Pflieger, S., V. Lefebvre, and M. Causse. 2001. The candidate gene approach in plant genetics: a review. Mol. Breed. 7:275-291.

Rabbani, M.A., K. Maruyama, H. Abe, M.A. Khan, K. Katsura, Y. Ito, et al. 2003. Monitoring expression profiles of rice genes under cold, drought, and highsalinity stresses and abscisic acid application asing cDNA microarray and RNA gel-blot analyses. Plant Physiol. 133:1755-1767.

Remans, T., K. Smeets, K. Opdenakker, D. Mathijsen, J. Vangronsveld, and A. Cuypers. 2008. Normalisation of real-time RT-PCR gene expression measurements in Arabidopsis thaliana exposed to increased metal concentrations. Planta 227:1343-1349.

Rensink, W., S. Iobst, A. Hart, S. Stegalkina, J. Liu, and C. Buell. 2005. Gene expression profiling of potato responses to cold, heat, and salt stress. Funct. Integr. Genomics 5:201-207.

Ritter, E., J. Ruiz de Galarreta, H. van Eck, and I. Sánchez. 2008. Construction of a potato transcriptome map based on the cDNA-AFLP technique. Theor. Appl. Genet. 116:1003-1013.

Rizhsky, L., H. Liang, J. Shuman, V. Shulaev, S. Davletova, and R. Mittler. 2004. When defense pathways collide. The response of Arabidopsis to a combination of drought and heat stress. Plant Physiol. 134:16831696.

Saijo, Y., S. Hata, J. Kyozuka, K. Shimamoto, and K. Izui. 2000. Over-expression of a single $\mathrm{Ca}^{2+}$-dependent protein kinase confers both cold and salt/drought tolerance on rice plants. Plant J. 23:319-327.

Sakurai, T., G. Plata, F. Rodríguez-Zapata, M. Seki, A. Salcedo, A. Toyoda, et al. 2007. Sequencing analysis of 20000 full-length cDNA clones from cassava reveals lineage specific expansions in gene families related to stress response. BMC Plant Biol. 7:66.
Schena, M., D. Shalon, R.W. Davis, and P.O. Brown. 1995. Quantitative monitoring of gene expression patterns with a complementary DNA microarray. Science 270:467-470.

Seki, M., M. Satou, T. Sakurai, K. Akiyama, K. Iida, J. Ishida, et al. 2004. RIKEN Arabidopsis full-length (RAFL) cDNA and its applications for expression profiling under abiotic stress conditions. J. Exp. Bot. 55:213-223.

Seki, M., J. Ishida, M. Narusaka, M. Fujita, T. Nanjo, T. Umezawa, et al. 2002. Monitoring the expression pattern of around 7000 Arabidopsis genes under ABA treatments using a full-length cDNA microarray. Funct. Integr. Genomics 2:282-291.

Shou, H., P. Bordallo, and K. Wang. 2004. Expression of the nicotiana protein kinase (NPK1) enhanced drought tolerance in transgenic maize. J. Exp. Bot. 55:10131019.

Song, S., H. Qu, C. Chen, S. Hu, and J. Yu. 2007. Differential gene expression in an elite hybrid rice cultivar (Oryza sativa, L.) and its parental lines based on SAGE data. BMC Plant Biol. 7:49.

Sreenivasulu, N., S.K. Sopory, and P.B. Kavi Kishor. 2007. Deciphering the regulatory mechanisms of abiotic stress tolerance in plants by genomic approaches. Gene 388:1-13.

Subramanian, A., P. Tamayo, V.K. Mootha, S. Mukherjee, B.L. Ebert, M.A. Gillette, et al. 2005. From the cover: Gene set enrichment analysis: A knowledge-based approach for interpreting genome-wide expression profiles. Proc. Natl. Acad. Sci. USA. 102:1554515550.

Tabata, S. 2002. Impact of genomics approaches on plant genetics and physiology. J. Plant Res. 115:271-275.

Thomashow, M.F. 1998. Role of cold-responsive genes in plant freezing tolerance. Plant Physiol. 118:1-8.

Torres, T.T., M. Metta, B. Ottenwälder, and C. Schlötterer. 2008. Gene expression profiling by massively parallel sequencing. Genome Res. 18:172-177.

van de Mortel, J.E., and M.G.M. Aarts. 2006. Comparative transcriptomics - model species lead the way. New Phytol. 170:199-201.

Velculescu, V.E., and K.W. Kinzler. 2007. Gene expression analysis goes digital. Nat. Biotech. 25:878-880.

Velculescu, V.E., L. Zhang, B. Vogelstein, and K.W. Kinzler. 1995. Serial analysis of gene expression. Science 270:484-487.

Vinocur, B., and A. Altman. 2005. Recent advances in engineering plant tolerance to abiotic stress: achievements and limitations. Curr. Opin. Biotechnol. 16:123-132. 
Wang, C.-R., A.-F. Yang, G.-D. Yue, Q. Gao, H.-Y. Yin, and J.-R. Zhang. 2008. Enhanced expression of phospholipase C 1 (ZmPLC1) improves drought tolerance in transgenic maize. Planta 227:1127-1140.

Wang, F.-Z., Q.-B. Wang, S.-Y. Kwon, S.-S. Kwak, and W.-A. Su. 2005. Enhanced drought tolerance of transgenic rice plants expressing a pea manganese superoxide dismutase. J. Plant Physiol. 162:465-472.

Wang, H., H. Zhang, F. Gao, J. Li, and Z. Li. 2007. Comparison of gene expression between upland and lowland rice cultivars under water stress using cDNA microarray. Theor. Appl. Genet. 115:1109-1126.

Wang, H., S. Miyazaki, K. Kawai, M. Deyholos, D.W. Galbraith, and H.J. Bohnert. 2003. Temporal progression of gene expression responses to salt shock in maize roots. Plant Mol. Biol. 52:873-891.

Weber, A.P.M., K.L. Weber, K. Carr, C. Wilkerson, and J.B. Ohlrogge. 2007. Sampling the arabidopsis transcriptome with massively parallel pyrosequencing. Plant Physiol. 144:32-42.

Xiang, Y., Y. Huang, and L. Xiong. 2007. Characterization of stress-responsive CIPK genes in rice for stress tolerance improvement. Plant Physiol. 144:14161428.

Xu, D., X. Duan, B. Wang, B. Hong, T.H.D. Ho, and R. Wu. 1996. Expression of a late embryogenesis abundant protein gene, HVA1, from barley confers tolerance to water deficit and salt stress in transgenic rice. Plant Physiol. 110:249-257.
Xu, D.-Q., J. Huang, S.-Q. Guo, X. Yang, Y.-M. Bao, H.-J. Tang, and H.-S. Zhang. 2008. Overexpression of a TFIIIA-type zinc finger protein gene ZFP252 enhances drought and salt tolerance in rice (Oryza sativa L.). FEBS Lett. 582:1037-1043.

$\mathrm{Xu}$, W.F., and W.M. Shi. 2006. Expression profiling of the 14-3-3 gene family in response to salt stress and potassium and iron deficiencies in young tomato (Solanum lycopersicum) roots: Analysis by real-time RT-PCR. Ann. Bot. (London) 98:965-974.

Yamaguchi, T., K. Nakayama, T. Hayashi, J. Yazaki, N. Kishimoto, S. Kikuchi, and S. Koike. 2004. cDNA Microarray analysis of rice anther genes under chilling stress at the microsporogenesis stage revealed two genes with DNA transposon castaway in the 5\&prime;-Flanking Region. Biosci. Biotechnol. Biochem. 68:1315-1323.

Yamamoto, M., T. Wakatsuki, A. Hada, and A. Ryo. 2001. Use of serial analysis of gene expression (SAGE) technology. J. Immunol. Methods 250:45-66.

Yokoi, S., S.-I. Higashi, S. Kishitani, N. Murata, and K. Toriyama. 1998. Introduction of the cDNA for shape Arabidopsis glycerol-3-phosphate acyltransferase (GPAT) confers unsaturation of fatty acids and chilling tolerance of photosynthesis on rice. Mol. Breed. 4:269-275.

Zhou, J., X. Wang, Y. Jiao, Y. Qin, X. Liu, K. He, et al. 2007. Global genome expression analysis of rice in response to drought and high-salinity stresses in shoot, flag leaf, and panicle. Plant Mol. Biol. 63:591-608. 


\title{
USE OF ENZYMATIC BIOSENSORS AS QUALITY INDICES: A SYNOPSIS OF PRESENT AND FUTURE TRENDS IN THE FOOD INDUSTRY
}

\author{
Liliana Serna Cock ${ }^{1 *}$, Ana María Zetty Arenas', and Alfredo Ayala Aponte ${ }^{2}$
}

\begin{abstract}
Biosensors are an important alternative in the food industry to ensure the quality and safety of products and process controls with effective, fast and economical methods. Their technology is based on a specific biological recognition element in combination with a transducer for signal processing. The use of enzymatic biosensor technology in food processing, quality control and on-line processes is promising compared to conventional analytical techniques, as it offers great advantages due to size, cost, specificity, fast response, precision and sensitivity. This article reviews the development and use of some enzyme biosensors in the food industry, describes the most important application areas and analyzes the current situation and future possibilities. In conclusion, enzymatic biosensors are a tool with broad application in the development of quality systems, risk analysis and critical control points, and the extent of their use in the food industry is still largely limited by the short lifetime of biosensors, in response to which the use of thermophilic enzymes has been proposed.
\end{abstract}

Key words: biosensors, enzymes, analysis in food, safety, quality, control processes.

\section{INTRODUCTION}

In recent decades increased knowledge about the biological capacity of enzymes has made it possible to create a new generation of products and processes. Among these products are notably biosensors, which represent a powerful alternative to conventional analytical technique (Velasco-García and Mottram, 2003). This technology has advanced considerably in recent years, basically because of the creation of devices applied in the area of biomedicine. These advanced technologies have been gradually transferred horizontally to other sectors, such as the environment and the agro-food industry.

A biosensor is defined as a compact device for analysis that incorporates a biological or biomimetic recognition element (nucleic acid, enzyme, anti-body, receptor, tissue, cell) associated with a transduction system that allows for processing the signal produced by the interaction between the recognition element and the analyte. The principle of detection of a biosensor is based on the specific interaction between the analyte of interest and the recognition element. As a result of this specific interaction, changes are produced

${ }^{1}$ Universidad Nacional de Colombia sede Palmira, Facultad de Ingeniería y Administración, Carrera 32 Chapinero, Vía Candelaria, Palmira, Colombia.

"Corresponding author (lsernac@palmira.unal.edu.co).

${ }^{2}$ Universidad del Valle, Facultad de Ingeniería, Edificio 338, Espacio 2016, Ciudad Universitaria, Cali, Colombia.

Received: 11 December 2007.

Accepted: 05 May 2008. in one or several physical-chemical properties (pH, electron transference, heat transference, change of potential or mass, variation of optical properties, etc.). These changes are detected and can be measured by a transductor (VelascoGarcía and Mottram, 2003). This system transforms the response of the recognition element into an electronic signal indicative of the presence of the analyte under study or proportional to its concentration in the sample.

Biosensors currently represent powerful tools for analysis with numerous applications in the agro-food industry, mainly in biotechnological instruments (Mello and Kubota, 2002). The most important characteristics of these devices to be competitive with other technologies in the agro-food industry are their specificity, high sensitivity, short response time, their capacity to be incorporated into integrated systems, the facility to automate them, their capacity to work in real time, their versatility and low production cost (Rasooly, 2001; Mello and Kubota, 2002; Velasco-García and Mottram, 2003).

In recent years, the number of scientific investigations and reviews on biosensors has been very high, which reflects the considerable interest in the theme. Ironically, there is a lag between the high level of scientific and technological development and the limited use of these devices in the agro-food sector (Velasco-García and Mottram, 2003) basically because of structural characteristics of the sector, such as legislation, methodological inertia, absorption capacity and environmental factors. The development of the diverse technologies involved in the design and construction of biosensors has allowed in recent years for 
resolving technical difficulties and personalized design of biosensors that, from the technical point of view, cover practically all needs.

The development of biosensors is described in numerous works, the majority in the areas of clinical, environmental, agricultural and biotechnological applications (Tothill, 2001). Their use in the food sector is convenient to ensure the quality and safety of foods (Luong et al., 1991). The potential uses of biosensors in agriculture and food transformation are numerous and each application has its own requirements in terms of the concentration of analyte to be measured, required output precision, the necessary volume of the sample, time required for the analysis, time required to prepare the biosensor or to reuse it and cleanliness requirements of the system (Velasco-García and Mottram, 2003).

Biosensors have been adapted to detect or measure analytes in "on-line" systems, that is, simultaneous with food processing (Rasooly, 2001). Hazard Analysis and Critical Control Point (HACCP) is generally regarded as the most effective system to ensure food safety. It is highly useful in verifying that processes are under control. The high sensitivity of enzymatic biosensors allows for the detection of microorganisms such as Escherichia coli, Salmonella sp., Staphylococcus aureus, pesticides and herbicides, among others, in hours and/or minutes (Fitzpatrick et al., 2000; Killard and Smyth, 2000).

Innovation and development in the food industry are guided by the central principles: food safety and quality (Mello and Kubota, 2002; Ferreira et al., 2003). The increasing complexity of the food chain requires, among other things, the development of effective traceability systems that guarantee the solidity of all the links. In both cases, the priority is to develop and install control systems such as biosensors that involve molecular methods of detection, analysis and diagnosis that are rapid, highly sensitive and automated tracing for a wide range of agents that threaten food safety.

Given the applicability of biosensors, this article reviews the development and use of some enzymatic biosensors in the food industry, describing the three main areas of application: food safety, food quality and process control, the current situation and future possibilities. As well, there is a brief commentary on the aspects of catalytic biosensors and their classification according to the type of interaction established between the recognition element and the analyte.

\section{Enzymatic biosensors}

A catalytic biosensor can be described as a compact analytic device that incorporates a biological sensing element, closely connected to or integrated with a transductor system (Velasco-García and Mottram, 2003). Biological sensors include enzymes or multi-enzymatic mediums, cellular organelles, complete cells or animal or vegetal tissue (Davis et al., 1995; Mello and Kubota, 2002; Wilson and Gifford, 2005), which are used to detect the presence of any of the substrates that participate in the reaction by detecting the disappearance of a known substrate distinct from the substrate being sought, or by the appearance of a known product; biological sensors are not consumed and can be reused (Gajovic et al., 2000; Wilson and Gifford, 2005).

In enzymatic biosensors a reaction occurs catalyzed by an enzyme in which the union of the substrate is produced in a concrete region of the enzyme termed the active center, which upon forming the products is recovered and can begin a new reaction cycle. The use of enzymes as biological recognition elements was very popular in the first generation of development of biosensors owing to their commercial availability or the facility for isolation and purification of diverse sources (Luong et al., 2008). Subsequently, other advantages were found in using enzymes in recognition biosensors, such as rapid response, high selectivity, the possibility of regeneration and the simplicity involved in constructing the devices (Hall, 2002). In numerous cases multi-enzymatic chains are employed, where the enzyme that generally recognizes the analyte does not act directly on it, but rather interacts with some product derived from it. This technique is often used, for example, with some sugars, where enzymes that are used react with the products of hydrolysis of the same. Among the enzymes that are commercially available, the most often used in biosensors are oxidoreductase, notably among which are glucose oxidase, horseradish peroxidase and alkaline phosphatase (Rogers and Mascini, 1998; Laschi et al., 2000), because they are very stable catalyzing reactions of oxide reduction (Mello and Kubota, 2002).

More than 2000 articles on enzyme-based biosensors were found in the literature and this is because of the need to examine blood glucose (Tothill, 2001; D’Orazio, 2003) and the feasibility of construction of the same. In the majority of the applications, the detection limits are satisfactory or excessive, but the stability of the enzymes and the capacity to maintain enzymatic activity over a long period of time continues to be problematic, which is generally resolved by immobilizing the enzymes (Tothill, 2001; D’Orazio, 2003). Immobilized enzymes offer advantages for application in different types of industrial processes and are adaptable to new engineering designs (Krajewska, 2004), for which it is important to increase the affinity of the enzyme to the substrate, reduce inhibition, increase the optimal $\mathrm{pH}$ interval and reduce possible microbial contamination (Arroyo, 1998). Basically, in enzymatic biosensors the enzymes are immobilized in a potentiometric, amperometric, optometric, calorimetric or piezoelectric transductor (Davis et al., 1995). 
In some cases electro-active interference caused by endogenous compounds in the sample for analysis becomes significant and needs to be eliminated. Currently, glucose oxidase continues to be the most stable and specific enzyme that can be easily obtained in large quantities (Luong et al., 2008).

On the other hand, there are enzymes that cannot be used because they are not sufficiently stable or because their purification is difficult or too costly, because of which cells from bacteria, fungus, protozoa and higher organisms are being used (Mello and Kubota, 2002). Instead of being purified, these cells are used as biological recognition elements, taking advantage of their diverse multi-cellular enzymatic systems that possess the capacity to metabolize different organic compounds, generating distinct products such as ammonia, carbon dioxide, acids, sugars, vitamins and nitrogenated compounds, among others, which can be detected in the biosensors, and in turn can be used to detect compounds that inhibit microbial respiration as toxic and contaminating substances (D’Souza, 2001). As well, the cells offer the facility to be modified genetically to improve their activity or to produce specific enzymes that do not normally appear.

One of the most important limitations in the use of complete cells is the diffusion of substrates and products by means of the cellular membrane, with which a slower response is obtained in comparison to purified enzyme biosensors, and with less specificity owing to reactions catalyzed by other enzymes present in the cell (D'Souza, 2001). These limitations can be reduced through the permeabilization of the cellular membrane by means of enzymatic processes with lysozyme, papain, chemical processes with detergents and physical processes with freezing and thawing (Mello and Kubota, 2002). These processes permit an increase in porosity of the membrane, allowing for better incorporation of the analyte and impede the escape of the intercellular macromolecular compounds, while the enzymes at the same time allow the co-factors that intervene in the catalytic reactions to leave to the exterior of the cell. Consequently, such treatments provoke cellular inviability, which limits their use to applications that do not require cellular regeneration of co-factors or metabolic respiration, as is the case of glucose oxidase, ß-galactosidase, amino acid oxidase and invertase (D’Souza, 2001).

Cells can be immobilized in membranes of cellulose acetate, or be trapped in a matrix, such as agar gel (Patel, 2002; Tatsumi et al., 2006; Setti et al., 2007) in a simpler and more economical way than enzymatic immobilization.

Other systems of catalytic biosensors instead of using complete cells or isolated multi-enzymatic include subcellular organelles or tissue, that contain more specific complete enzymatic systems, as is the case of thylakoids, complete chloroplasts or mitochondria, which are doublemembrane organelles that have enzymatic systems related to obtaining energy. Such organelles are used in the detection of toxic agents such as pesticides, heavy metals or detergents that can inhibit enzymatic systems (D'Souza, 2001). In the same manner, there are determined tissues that according to their physiological function in the organism produce specific enzymes or enzymatic systems, such as leaves, roots, fruits or seeds, in sliced or in homogenized form; such tissue are often associated with electrochemical transductors (Li et al., 2002; Wilson and Gifford, 2005; Mei et al., 2007). For example, for the detection of phenol impregnated in salmon, salmon tissue is used in an electrochemical biosensor of carbon and tyrosinase mixed with electropolymerized pyrrole (Tingry et al., 2006); slices of potato are used for the determination of mono and polyphenoles (Solanum tuberosum L.) because of their high content of polyphenol oxidase enzymes, together with oxygen electrodes (D’Souza, 2001; Kulys and Vidziunaite, 2003); for the determination of alcohol, homogenized fungus Agaricus bisporus is used (Akyilmaz and Dinckaya, 2000; Kulys and Vidziunaite, 2003); for the determination of diamines like putrescine and cadaverine, tissue is used from chemiluminescent plants, based on the enzymatic conversion that takes place in the column of tissue of the plants to produce hydrogen peroxide (Mei et al., 2007), among many others examples.

The application of more than one sensor channel for one or more species in a unit using enzyme-electrode type amperometric sensors has led to the development of several multi-sensors based on principles of amperometric detection (Silber et al., 1994; Miertus et al., 1998). The use of electro-chemical transductors of various channels allows for the construction of biosensors that can simultaneously analyze three or more species and in this manner optimize selectiveness and reliability in comparison to sensors with only one substrate (Glazier et al., 1988).

\section{Potential applications of enzymatic biosensors in the agro-food industry}

Applications in food safety. The concept of food safety involves ensuring the production and marketing of harmless food, with this, ensure the health of the consumer. The quantity and types of food additives incorporated into food products are regulated by the legislation of each country, the detection and quantification of which are important to prevent fraud and malpractice by manufacturers, allergies and other adverse effects to determined groups of the population (Zinedine et al., 2007). Because of this, special attention has been given to studying the way to detect the presence of contaminants, such as residues of pesticides, fertilizers, 
heavy metals and organic compounds, given that the majority of these have a high level of toxicity. Based on this need biosensors are used to detect xenobiotic substances, substances external to the food product such as additives and pesticides and components of the food itself like toxines of diverse origins (Xavier et al, 2000; Patel, 2002). The traditional methods to identify food contaminants include physiochemical, serological and biological tests, however many of these require large quantities of prepared samples, analysis time and lack sufficient sensitivity and selectivity.

The development of catalytic biosensors in food additive analysis generally employs enzymes as recognition systems. This development is described in several investigations, among these notably are analysis of aspartame with carboxyl esterase, alcohol oxidase, caboxypeptidase, L-aspartase, peptidase, aspartate aminotransferase, glutamate oxidase and $\alpha$-chymotrypsin (Odaci et al., 2004); analysis of sorbitol with sorbitol dehydrogenase and nicotinamide adenine dinucleotide (NAD+) (Saidman et al., 2000); analysis of benzoic acid with tyrosine (Morales et al., 2002) and analysis of sulphites with sulphite oxidase; all developed with a system of amperometric transduction. In some cases interference reactions have been observed that reduce the efficacy of these devices, as occurs with biosensors used to detect sorbitol which also interact with another artificial edulcorant, xylitol; and with devices designed for the determination of benzoic acid by the presence of other antioxidants such as butyl hydroxyanisole (BHA) and propyl gallate (Patel, 2002). Table 1 presents the main biosensors used in the detection of these types of compounds in food and water; among these are devices based on the inhibition of enzymatic activities that incorporate enzymes such as cholinesterases (acetyl and/or butyrylcholinesterases), tyrosinase or alkaline phosphatase; and units in which reactions are catalyzed that affect the analyte of interest, which include hydrolases, reductases, etc. (Nunes et al., 1998; Bachmann et al., 2000; Panfili et al., 2000).

The different pesticides used in food production can accumulate in the fatty tissue of animals, while the excessive use of fertilizers contaminates ground water with nitrates, nitrites and phosphates (Cosnier et al., 1998; Moretto et al., 1998). For the detection of herbicides such as phenyl urea and triazines, which inhibit photosynthesis, biosensors have been designed with membrane receptors of thylakoid and chloroplasts, photosystems and reaction centers; or complete cells such unicellular alga and fenilureas and triazines, for which mainly amperometric and optical transductors have been employed (Patel, 2002).
There are also other substances potentially toxic for humans with a major impact on the environment that can reach the food chain accidentally, such as contaminating residues present in water and soil, among these byproducts from diverse industrial processes (dioxins), used as dielectric or hydraulic fluid agents (polychlorinated biphenyls or PCBs) or generated in the burning of fossil fuels or wood (polycyclic aromatic hydrocarbons or PAHs), benzene, toluene and xylene (named BETX) and derived phenolics; immunosensors, enzymatic biosensors and biosensors with complete cells are used for the detection of these organic compounds (Hedenmo et al., 1997; Patel, 2002). Likewise, devices have been designed to determine the levels of heavy metals such as arsenic, cadmium, mercury, lead, among others, in samples of water and soil, which incorporate genetically modified microorganisms and enzymes such as urease, cholinesterase, glucose oxidase, alkaline phosphatase, ascorbate oxidase and peroxidase (Tsai et al., 2003), the transduction systems in these devices are notably electrochemical and optical, as indicated in Table 1.

On the other hand, foods can naturally present antinutritional compounds that can generate disorders in the consumer, given that they hinder absorption and metabolize distinct nutrients causing a deficiency of the same. Table 2 presents some examples of biosensors used in the detection of anti-nutrients.

Applications in food quality. The term food quality is related to nutritional value, acceptability and safety. The latter was analyzed in the previous section and the others are evaluated in function of parameters such as freshness, appearance, flavor, texture and chemical (Vadiuambal and Jayas, 2007). The composition of the foods allows for characterization and verification if the food contains elements to enrich the food such as vitamins and/or minerals. To evaluate food composition distinct biosensors have been developed, which are described in Table 3.

Various food labeling regulations recognize the importance of determining freshness, establishing guidelines for the use of the term "fresh" in relation to food (FSA, 2004). One way to determine freshness is through evaluation of the composition of products such as meats, fish, fruits and vegetables, given that during periods of storage compounds can by synthesized that produce abnormal odors and flavors and are prejudicial to the health of the consumer. Table 4 lists the biosensors developed to evaluate the freshness and useful life of foods.

Some of the most important problems that affect food freshness, and with it food quality, are exposure time in an inadequate environment, incorrect design of the food packaging, inadequate management of temperatures 
Table 1. Most important biosensors used in the detection of pesticides, fertilizers and other pollutants.

\begin{tabular}{|c|c|c|c|c|}
\hline Analyte & $\begin{array}{c}\text { Type of } \\
\text { interaction }\end{array}$ & $\begin{array}{l}\text { Recognition } \\
\text { biocatalyzer }\end{array}$ & $\begin{array}{c}\text { Transduction } \\
\text { system }\end{array}$ & References \\
\hline \multicolumn{5}{|c|}{ Pesticides } \\
\hline Parathion & Biocatalytic & Parathion hydrolase & Amperometric & $\begin{array}{l}\text { Velasco-García y } \\
\text { Mottram, 2003; } \\
\text { Parellada et al., } 1998\end{array}$ \\
\hline Propoxur and carbaryl & Biocatalytic & Acetyl cholinesterase & Fiber optic & $\begin{array}{l}\text { Nunes et al., 1998; } \\
\text { Xavier et al., } 2000\end{array}$ \\
\hline Diazinon and dichlorvos & Biocatalytic & Tyrosinase & Amperometric & $\begin{array}{l}\text { Pérez Pita et al., 1997; } \\
\text { Mello y Kubota, } 2002\end{array}$ \\
\hline Paraoxon & Biocatalytic & Alkaline phosphatase & Optical & $\begin{array}{l}\text { Cosnier et al., 1998; } \\
\text { Mello and Kubota, } \\
\text { 2002; Patel, } 2002\end{array}$ \\
\hline
\end{tabular}

\section{Fertilizers}

\begin{tabular}{|c|c|c|c|c|}
\hline Nitrate & Biocatalytic & Nitrate reductase & Amperometric & Moretto et al., 1998 \\
\hline Nitrite & Biocatalytic & Nitrite reductase & Optical & Moretto et al., 1998 \\
\hline Phosphate & Biocatalytic & $\begin{array}{l}\text { Polyphenol oxidase and } \\
\text { alkaline phosphatase, } \\
\text { phosphorylase A, } \\
\text { phosphoglucomutase and } \\
\text { glucose-6-phosphate } \\
\text { dehydrogenase }\end{array}$ & Amperometric & Cosnier et al., 1998 \\
\hline
\end{tabular}

\section{Heavy metals}

\begin{tabular}{|c|c|c|c|c|}
\hline Copper and mercury & Biocatalytic & Spirulina subsalsa & Amperometric & $\begin{array}{l}\text { Tsai, 2003; Velasco- } \\
\text { García and Mottram, } 2003\end{array}$ \\
\hline Copper & Biocatalytic & $\begin{array}{l}\text { Recombinant Saccharomyces } \\
\text { cerevisiae }\end{array}$ & Amperometric & $\begin{array}{l}\text { Tsai, 2003; Velasco- } \\
\text { García and Mottram, } 2003\end{array}$ \\
\hline Cadmium and lead & Biocatalytic & $\begin{array}{l}\text { Staphylococcus aureus or } \\
\text { Recombinant Bacillus subtilis }\end{array}$ & Optical & $\begin{array}{l}\text { Tsai, 2003; Velasco- } \\
\text { García and Mottram, } 2003\end{array}$ \\
\hline $\begin{array}{l}\text { Arsenic, cadmium and } \\
\text { bismuth }\end{array}$ & Biocatalytic & Cholinesterase & Electrochemical & $\begin{array}{l}\text { Tsai, 2003; Velasco- } \\
\text { García and Mottram, } 2003\end{array}$ \\
\hline $\begin{array}{l}\text { Cadmium, copper, } \\
\text { chrome, nickel, zinc }\end{array}$ & Biocatalytic & Ureasa & Optical & $\begin{array}{l}\text { Tsai, 2003; Velasco- } \\
\text { García and Mottram, } 2003\end{array}$ \\
\hline Copper and mercury & Biocatalytic & Glucose oxidase & Amperometric & $\begin{array}{l}\text { Tsai, 2003; Velasco- } \\
\text { García and Mottram, } 2003\end{array}$ \\
\hline
\end{tabular}

and the level of oxygen during the handling of fruit and vegetables in modified atmospheres, among many others. Because of this, experimental use has been made of commercial biosensors that use immobilized enzymes like alcohol oxidase and alcohol peroxidase and a chromogene, in which alcohol oxidase catalyzes the oxidation of ethanol in acetaldehyde and $\mathrm{H}_{2} \mathrm{O}_{2}$ in the presence of $\mathrm{O}_{2}$, and the peroxidase catalyzes the oxidation of the chromogene, causing a change in color. Smyth et al. (1999), measuring with biosensors, ethanol accumulation in lettuce (Lactuca sativa L.), cauliflower (Brassica oleracea var. botrytis), broccoli (Brassica oleracea var. italica) and cabbage (Brassica oleracea var. capitata) lightly processed and packed in a modified atmosphere, detected lesions due to low concentration of $\mathrm{O}_{2}$ and obtained a response from the biosensor that was very similar to that obtained by gas chromatography, which is costly and requires technical experts. This biosensor can also be used monitor ethanol formation during apple storage in a controlled atmosphere, the development of putrefaction in tubercles like potatoes or for any other application where ethanol accumulation can be associated with quality loss. Likewise, research has 
Table 2. Some of the most commonly used biosensors in antinutrient detection.

\begin{tabular}{lcccc}
\hline Analyte & $\begin{array}{c}\text { Type of } \\
\text { interaction }\end{array}$ & $\begin{array}{c}\text { Recognition } \\
\text { system }\end{array}$ & $\begin{array}{c}\text { Transduction } \\
\text { system }\end{array}$ & References \\
\hline Oxalate (spinaches, tea, strawberries) & \multicolumn{3}{c}{ Antinutrients } & \\
Amygdalin (bitter almonds) & Biocatalytic & $\begin{array}{l}\text { Oxalate oxidase } \\
\text { B-glucosidase }\end{array}$ & $\begin{array}{l}\text { Amperometric } \\
\text { Amperometric }\end{array}$ & Milardovic et al., 2000 \\
& & & $\begin{array}{l}\text { Potentiometric } \\
\text { Glucoalcaloides }\end{array}$ & Ohashi and Karube, 1993 \\
\hline
\end{tabular}

been conducted that analyzes the content of some organic acids and sugars as indicators of fruit and vegetable maturity (Ángeles and Cañizares, 2004).

There are multiple compounds that give rise to disagreeable flavors and aromas that can be detected with biosensors, as in the case of 2,4,6-tricloroanisole in wine (Moore et al., 2003), which is related to wine bottle corks, whose presence causes significant losses to the wine industry. In other cases, the level of freshness of fish has been detected through a hydrogen peroxide electrode based on the xanthine oxidase enzyme (Volpe and Mascini, 1996). Biosensors can also detect indicators of processes, such as lactulose, disaccharide, which is formed in the thermal treatment of milk allows for distinguishing between milk that has been submitted to a UHT treatment (ultra high temperature) and milk sterilized in the container.

Applications in process control. Currently, thanks to biosensor technology it is possible to determine and quantify on-line diverse compounds of importance in process control, such as sugars, alcohols, and amino acids, among others.

Sugars are limiting factors in fermentative processes given that low concentrations reduce the productivity of the bioreactor. Because of this, numerous investigations have been undertaken, among which notably are those on the use of amperometric biosensors to analyze glucose with glucose oxidase in fruit juices (Ángeles and Cañizares, 2004); lactose with ß-galactosidase and glucose oxidase; and lactulose with ß-galactosidase and fructose dehydrogenase, which implies an excessive thermal treatment of milk during pasteurization (Campás et al., 2002). In relation to alcohols and principally ethanol, enzymatic reactions are inhibited when alcohol content exceeds $14 \%$; analysis has been advanced mainly with the alcohol dehydrogenase enzyme Gluconobacter oxydans with amperometric biosensors; likewise, with fermentation, the proportion of glycerol should be maintained at 1:10 in relation to total alcohol, the analysis of glycerol has been developed with glycerokinase and glycerol-3-phosphate oxidase in amperometric biosensors to monitor fermentative processes (Niculescu et al., 2003). On the other hand, aminoacids like lysine, obtained by fermentation and employed as animal feed supplements, has been controlled by the lysine oxidase enzyme. Similarly, lactic acid used to control acidity and the formation of crusts on cheese, have been examined with lactate oxidase in amperometric biosensors. These biosensors can be integrated into the system of Hazard Analysis and Critical Control Points (HACCP) to verify that processes are being carried out correctly.

Despite the broad applicability of biosensors, the use of the technology in the control of processes is limited for several reasons: the short life of enzymatic biosensors, the need to calibrate them with certain frequency, the lack of reliable response to different concentrations or with variable conditions in the medium, among others (Ferreira et al., 2003). The prototype tests in real samples have critical stages such as immobilization of the biocomponent during the construction of the device and preparation of the sample for analysis. Biosensors require mild temperature and $\mathrm{pH}$ conditions to keep the biological element active (Gibson, 1999; Wilson and Gifford, 2005). Consequently, in some cases a previous treatment of the sample is recommended to eliminate interfering species such as ascorbic acid, tyrosine and others. Procedures are conducted that include neutralization, dilution or extraction when the food is acidic or hydrophobic. The correction methods to reduce the duration of food analysis include acidic or alkaline hydrolysis, microwave digestion, extraction of supercritical fluids, evaporation and filtration (Deng and Dong, 1996; Marconi et al., 1996; Kotsira and Clonis, 1998; Panfili et al., 2000). Likewise, specific sensors have been developed for the determination of glucose, lactate, glutamate, pyruvate, choline and acetylcholine through monitoring of nitric oxide, $\mathrm{Na}^{+}, \mathrm{K}^{+}, \mathrm{Ca}^{2+}$, and dopamine (Zhang and Wilson, 1998; Wilson and Gifford, 2005).

\section{CONCLUSIONS}

The food industry is benefitting from major advances in the development of enzymatic biosensors with different transduction systems that can be applied in the areas of food safety, quality and process control; studies are focused mainly on determining composition, contamination of primary materials and processed foods. 
Table 3. Most important biosensors applied to evaluate food quality.

\begin{tabular}{|c|c|c|c|c|}
\hline Analyte & Matrix & $\begin{array}{l}\text { Recognition } \\
\text { enzyme }\end{array}$ & $\begin{array}{c}\text { Transduction } \\
\text { system }\end{array}$ & References \\
\hline Glucose & $\begin{array}{l}\text { Grape juice, wine, juice, } \\
\text { honey, milk and yogurt }\end{array}$ & Glucose oxidase & Amperometric & $\begin{array}{l}\text { Centonze et al., 1997; } \\
\text { Ángeles y Cañizares, } 2004\end{array}$ \\
\hline Fructose & $\begin{array}{l}\text { Juice, honey, milk, gelatin } \\
\text { and artificial edulcorants }\end{array}$ & $\begin{array}{l}\text { Fructose dehydrogenase, } \\
\text { D-fructose 5- } \\
\text { dehydrogenase }\end{array}$ & Amperometric & $\begin{array}{l}\text { Bassi et al., 1998; } \\
\text { Palmisano et al., } 2000\end{array}$ \\
\hline Lactose & Milk & ß-Galactosidase & Amperometric & $\begin{array}{l}\text { Marconi, 1996; Palmisano } \\
\text { et al., } 2000\end{array}$ \\
\hline Lactate & Cider and wine & $\begin{array}{l}\text { Transaminase and L- } \\
\text { lactate dehydrogenase }\end{array}$ & Amperometric & $\begin{array}{l}\text { Silber et al., 1994; } \\
\text { Ramanathan et al., } 2001\end{array}$ \\
\hline Lactulose & Milk & $\begin{array}{l}\text { Fructose dehydrogenase } \\
\text { and ß-galactosidase }\end{array}$ & Amperometric & Sekine and Hall, 1998 \\
\hline $\begin{array}{l}\text { L-amino } \\
\text { acids }\end{array}$ & Milk and fruit juices & D-amino acid oxidase & Amperometric & Sarkar et al., 1999 \\
\hline L-glutamate & $\begin{array}{l}\text { Soya sauce and } \\
\text { condiments }\end{array}$ & L-glutamate oxidase & Amperometric & $\begin{array}{l}\text { Matsumoto et al., 1998; } \\
\text { Kwong et al., } 2000\end{array}$ \\
\hline L-lysine & $\begin{array}{l}\text { Milk, pasta and } \\
\text { fermentation samples }\end{array}$ & Lysine oxidase & Amperometric & $\begin{array}{l}\text { Kelly et al., 2000; } \\
\text { Olschewski et al, } 2000\end{array}$ \\
\hline L-malate & Wine, cider and juices & $\begin{array}{l}\text { Dehydrogenated malate, } \\
\text { others }\end{array}$ & Amperometric & Miertus et al., 1998 \\
\hline Ethanol & $\begin{array}{l}\text { Beer, wine and other } \\
\text { alcoholic drinks }\end{array}$ & $\begin{array}{l}\text { Alcohol oxidase, alcohol } \\
\text { dehydrogenase, } \mathrm{NaDH} \\
\text { oxidase }\end{array}$ & Amperometric & $\begin{array}{l}\text { Katrlık, } 1998 \text {; Miertus et } \\
\text { al., } 1998\end{array}$ \\
\hline Glycerol & Wine & $\begin{array}{l}\text { Glycerophosphate } \\
\text { oxidase and glycerol } \\
\text { kinase }\end{array}$ & Amperometric & Niculescua et al., 2003 \\
\hline Catechol & Beer & Polyphenol oxidase & Amperometric & Eggins et al., 1997 \\
\hline Cholesterol & Butter, lard and egg & $\begin{array}{l}\text { Cholesterol oxidase and } \\
\text { peroxidase }\end{array}$ & Amperometric & $\begin{array}{l}\text { Akyilmaz and Dinckaya, } \\
2000 .\end{array}$ \\
\hline Citric acid & Juice and athletic drinks & Citrate lyase & Amperometric & Prodromidis et al., 1997 \\
\hline Lecithin & $\begin{array}{l}\text { Egg yolk, flour and soya } \\
\text { sauce }\end{array}$ & $\begin{array}{l}\text { Phospholipase D and } \\
\text { choline oxidase }\end{array}$ & Electrochemical & Mello and Kubota, 2002 \\
\hline
\end{tabular}

In the area of food safety, enzymatic biosensors allow for identifying the presence of highly toxic organic contaminants and the presence of anti-nutritional elements that affect the food chain, either accidently or by intention. This early detection protects the environment from contaminants and consumers from chronic illnesses and allergies.

Equally, enzymatic biosensors are being used in the food industry to determine the freshness of products given that it is possible to detect enzymes and compounds of aroma and flavor that originate from the senescence stage of products.

Biosensors have proven to be especially useful in the control of fermentative processes in follow-up of the consumption of the substrate by microorganisms, control of acidity and assessing the thermal profile.
While the use of biosensors in the food industry is on a mass scale, there are still obstacles to be overcome, such as the high cost of purifying the enzymes that are used as detecting elements, the low specificity and low response time that are obtained when complete cells or tissue are used, the lack of reliable responses low concentrations, interference reactions, the need to calibrate the devices and the stability of the enzymes. This last factor is the most limiting for the lifetime of enzymatic biosensors. If these limiting factors can be overcome, it will be possible to develop enzymatic biosensors that are more rapid, versatile, reliable, long lasting and cost-effective. 
Cuadro 4. Biosensor used in the evaluation of freshness and self life.

\begin{tabular}{lllll}
\hline Analyte & Matrix & \multicolumn{1}{c}{$\begin{array}{c}\text { Recognition } \\
\text { enzyme }\end{array}$} & $\begin{array}{c}\text { Transduction } \\
\text { system }\end{array}$ & References \\
\hline Polyphenols & Olive oil & Evaluation of spoilage & \\
$\begin{array}{c}\text { Short chain } \\
\text { fatty acid }\end{array}$ & Milk and derivatives & Lipase & Amperometric & $\begin{array}{l}\text { Campanella et al., 1993; } \\
\text { Kulys and Vidziunaite, 2003 } \\
\text { Mello and Kubota, 2002 }\end{array}$ \\
\hline
\end{tabular}

\section{Freshness index}

\begin{tabular}{|c|c|c|c|c|}
\hline $\begin{array}{l}\text { Ornithine } \\
\text { and amines }\end{array}$ & Shrimps & $\begin{array}{l}\text { Ornititne carbamoyl } \\
\text { transferase, nucleoside } \\
\text { phosphorylase and } \\
\text { xanthine oxidase }\end{array}$ & Amperometric & Mello and Kubota, 2002 \\
\hline
\end{tabular}

\begin{tabular}{|c|c|c|c|c|}
\hline Amines & Fish, lobster & $\begin{array}{l}\text { Diamine oxidase, } \\
\text { Ornithine carbamoyl } \\
\text { transferase, nucleoside } \\
\text { phosphorylase }\end{array}$ & Amperometric & $\begin{array}{l}\text { Park et al., 2000; Mello and } \\
\text { Kubota, } 2002\end{array}$ \\
\hline $\begin{array}{l}\text { Biogenic } \\
\text { amines }\end{array}$ & Fish & $\begin{array}{l}\text { Amine oxidase and } \\
\text { peroxidase }\end{array}$ & Amperometric & Tombelli and Mascini, 1998 \\
\hline $\begin{array}{l}\text { Hypoxan } \\
\text { thine }\end{array}$ & Fish & Xanthine oxidase & Amperometric & Hu et al., 2000 \\
\hline Lactic acid & Meat & $\begin{array}{l}\text { Xanthine oxidase, } \\
\text { diamine oxidase } \\
\text { Polymide oxidase }\end{array}$ & Amperometric & Mello and Kubota, 2002 \\
\hline
\end{tabular}

\section{Evaluation of maturity}

\begin{tabular}{|c|c|c|c|c|}
\hline Glucose & Fruit & Glucose oxidase & Electrochemical & Ramanathan et al., 2001 \\
\hline Sucrose & Fruit & $\begin{array}{l}\text { Invertase, mutarotase and } \\
\text { glucose oxidase }\end{array}$ & Electrochemical & Mello and Kubota, 2002 \\
\hline Isocitrate & Fruit & Isocitrate dehydrogenase & Potentiometric & Mello \& Kubota, 2002 \\
\hline
\end{tabular}

\section{RESUMEN}

Uso de biosensores enzimáticos como indicadores de calidad: Una sinopsis del presente y futuro en la industria alimentaria. Los biosensores constituyen una importante alternativa en la industria de alimentos para garantizar la calidad e inocuidad de los productos y controlar los procesos con métodos eficaces, rápidos y económicos; su tecnología está basada en un elemento de reconocimiento biológico específico en combinación con un transductor para el procesamiento de la señal. El uso de técnicas de biosensores enzimáticos en procesamiento de alimentos, control de calidad y de procesos "on line", es prometedor frente a las técnicas analíticas convencionales, ya que ofrecen grandes ventajas debido a su tamaño, costo, especificidad, respuesta rápida, precisión y sensibilidad. En este artículo se revisa el desarrollo y uso de algunos biosensores enzimáticos en la industria alimentaria, se describen las áreas de aplicación más importantes y se analiza su situación actual y posibilidades futuras. En conclusión, los biosensores enzimáticos son una herramienta de gran aplicabilidad en el desarrollo de sistemas de calidad como el análisis de riesgos y puntos críticos de control, y que la masificación de su uso en la industria alimentaria se ve aún limitada principalmente por el tiempo de vida útil de los biosensores, para lo cual se propone el uso de enzimas termofílicas.

Palabras clave: biosensores, enzimas, análisis en alimentos, seguridad, calidad, control de procesos. 


\section{LITERATURE CITED}

Akyilmaz, E., and E. Dinckaya. 2000. A mushroom (Agaricus bisporus) tissue homogenate based alcohol oxidase electrode for alcohol determination in serum. Talanta 53:505-509.

Ángeles A., y M. Cañizares. 2004. Desarrollo de un sistema sensor para la cuantificación de glucosa en jugos de frutas. Rev. Soc. Quím. Méx. 8:106-110.

Arroyo, M.1998. Inmovilización de enzimas. Fundamentos, métodos y aplicaciones. Ars Pharmaceutica 39:23-39.

Bachmann, T.T., B. Leca, F. Vilatte, J.L. Marty, D. Fournier, and R.D. Schmid. 2000. Improved multianalyte detection of organophosphates and carbamates with disposable multielectrode biosensors using recombinant mutants of Drosophila acetylcholinesterase and artificial neural networks. Biosens. Bioelectron. 15:193-201.

Bassi, A.S., E. Lee, and J.X. Zhu. 1998. Carbon paste mediated, amperometric, thin film biosensors for fructose monitoring in honey. Food Research Internacional 31:119-127.

Campanella, L., T. Beone, M.P. Sammartino, and M. Tomassetti. 1993. Analysis of L-dopa in pharmaceutical preparations and of total phenols content in urine by means of an enzyme-amperometric sensor. J. Pharm. Biomed. Anal. 11:1099-1104.

Campás, M., M. Mir, C. O’Sullivan, y I. Katakis. 2002. Biosensores al servicio de la industria alimentaria. In $2^{\circ}$ Congreso Español de Ingeniería de Alimentos, Lleida, España.

Centonze, D., C.G. Zambonin, and F. Palmisano. 1997. Determination of glucose in nonalcoholic beverages by a biosensor coupled with microdialysis fiber samplers. Journal of AOAC International 80:829-833.

Cosnier, S., C. Gondran, J.C. Watelet, W. De Giovani, R.P.M. Furriel, and F.A. Leone. 1998. A bienzyme electrode (alkaline phosphatase-polyphenol oxidase) for the amperometric determination of phosphate. Anal. Chem. 70:3952-3956.

Davis, J., D. Huw Vaughan, and M.F. Cardosi. 1995. Elements of biosensors construction. Enzyme Microb. Technol. 17:1030-1035.

Deng, Q., and S. Dong. 1996. Amperometric biosensor for tyrosinase inhibitors in a pure organic phase. Analyst 121:1979-1982.

D’Orazio, P. 2003. Biosensors in clinical chemistry. Clin. Chim. Acta 334:41-69.

D’Souza, S.F. 2001. Microbial biosensors. Biosen. Bioelectron. 16:337-353.

Eggins, B.R., C. Hickey, S.A. Toft, and D.M. Zhou. 1997. Determination of flavonols in beers with tissue biosensors. Anal. Chim. Acta 347:281-288.
Ferreira, S., M.B. De Souza, J.O. Trierweiler, O. Broxtermann, R.O.M. Folly, and B. Hitzmann. 2003. Aspects concerning the use of biosensors for process control: experimental and simulation investigations. Comput. Chem. Eng. 27:1165-1173.

Fitzpatrick, J., L. Fanning, S. Hearty, P. Leonard, B.M. Manning, J.G. Quinn, and R. O’Kennedy. 2000. Applications and recent developments in the use of antibodies for analysis. Anal. Lett. 33:2563-2609.

FSA. 2004. An investigation of the use of terms such as natural, fresh etc. in food labeling. Survey report of the February 11, 2004, Food Labelling and Standards Division, Food Standards Agency. (FSA), UK.

Gajovic, N., G. Binyamin, A. Warsinke, F.W. Scheller, and A. Heller. 2000. Operation of a miniature redox hydrogel-based pyruvate sensor in undiluted deoxygenated calf serum. Anal. Chem. 72:29632968.

Gibson, T.D. 1999. Biosensors: the stability problem. Analusis 27:630-638.

Glazier, S.A., M.A. Arnold, and J.P. Glazier. 1988. Evaluation of an overdetermined system based on multiple ion-selective electrodes of the same type. Talanta 35:215-219.

Hall, R.H. 2002. Biosensor technologies for detecting microbiological foodborne hazards. Microbes and Infect. 4:425-432.

Hedenmo, M., A. Narváez, E. Domínguez, and I. Katakis. 1997. Improved mediated tyrosinase amperometric enzyme electrodes. J. Electroanal. Chem. 425:1-11.

Hu, S., C. Xu, J. Luo, J. Luo, and D. Cui. 2000. Biosensor for detection of hypoxanthine based on xanthine oxidase immobilized on chemically modified carbon paste electrode. Anal. Chim. Acta 412:55-61.

Katrlık, J., J. Svorc, M. Stred'ansky, and S. Miertus. 1998. Composite alcohol biosensors based on solid binding matrix. Biosens. Bioelectron. 13:183-191.

Kelly, S.C., P.J. O’Connell, C.K. O’Sullivan, and G.G. Guilbault. 2000. Development of an interferent free amperometric biosensor for determination of L-lysine in food. Anal. Chim. Acta 412:111-119.

Killard, A.J., and M.R. Smyth. 2000. Separation-free electrochemical immunosensor strategies. Anal. Lett. 33:1451-1465.

Kotsira, V.P., and Y.D. Clonis. 1998. Colorimetric assay for lecithin using two co-immobilized enzymes and an indicator dye conjugate. J. Agric. Food Chem. 46:3389-3394.

Krajewska, B. 2004. Application of chitin- and chitosanbased materials for enzyme immobilizations: a review. J. Biotechnol. 35:126-139. 
Kwong, A.W.K., B. Gründig, J. Hu, and R. Renneberg. 2000. Comparative study of hydrogel-immobilized L-glutamate oxidases for a novel thick-film biosensor and its application in food samples. Biotechnol. Lett. 22:267-272.

Kulys, J., and R. Vidziunaite. 2003. Amperometric biosensors based on recombinant laccases for phenols determination. Biosen. and Bioelectron. 18:319-325.

Laschi, S., M. Fránek, and M. Mascini. 2000. Screenprinted electrochemical immunosensors for PCB detection. Electroanalysis 12:1293-1298.

Li, B., Z. Zhang, and Y. Jin. 2002. Plant tissuebased chemiluminescence flow biosensor for determination of unbound dopamine in rabbit blood with on-line microdialysis sampling. Biosens. and Bioelectron.17:585-589.

Luong, J.H.T, C.A. Groom, and K.B. Male. 1991. The potential role of biosensors in the food and drink industries. Biosens. and Bioelectron. 6:547-554.

Luong, J.H.T., K.B. Male, and J.D. Glennon. 2008. Biosensor technology: technology push versus market pull. Biotechnol. Adv. 26:492-500.

Marconi, E., G. Panfili, M.C. Messia, R. Cubadda, D. Compagnone, and G. Palleschi. 1996. Fast analysis of lysine in food using protein microwave hydrolysis and an electrochemical biosensor. Anal. Lett. 29:1125-1137.

Matsumoto, K., W. Asada, and R. Murai. 1998. Simultaneous biosensing of inosine monophosphate and glutamate by use of immobilized enzyme reactors. Anal. Chim. Acta 358:127-136.

Mei, Y., L. Ran, X. Ying, Z. Yuan, and S. Xin. 2007. A sequential injection analysis/chemiluminescent plant tissue-based biosensor system for the determination of diamine. Biosens. Bioelectron. 22:871-876.

Mello, L.D., and L.T. Kubota. 2002. Review of the use of biosensors as analytical tools in the food and drink industries. Food Chem. 77:237-256.

Miertus, S., J. Katrlík, A. Pizzariello, M. Stred’anský, J. Svitel, and J. Svorc. 1998. Amperometric biosensors based on solid binding matrices applied in food quality monitoring. Biosens. Bioelectron. 13:911-923.

Milardovic, S., Z. Grabaric, and B.S. Grabaric. 2000. Sensitive amperometric oxalate biosensor for food analysis. Food Technol. Biotechnol. 38:203-210.

Moore, E., M. Pravda, and G.G. Guilbault. 2003. Development of a biosensor for the quantitative detection of 2,4,6-trichloroanisole using screen printed electrodes. Anal. Chim. Acta 484:15-24.

Morales, M.D., S. Morante, A. Escarpa, M.C. González, A.J. Reviejo, and J.M. Pingarrón. 2002. Design of a composite amperometric enzyme electrode for the control of the benzoic acid content in food. Talanta 57:1189-1198.
Moretto, L.M., P. Ugo, M. Zanata, P. Guerriero, and C.R. Martin. 1998. Nitrate biosensor based on the ultrathinfilm composite membrane concept. Anal. Chem. 70:2163-2166.

Niculescu, M., R. Mieliauskiene, V. Laurinavicius, and E. Csöregi. 2003. Simultaneous detection of ethanol, glucose and glycerol in wines using pyrroloquinoline quinone dependent dehydrogenases based biosensors. Food Chem. 82:481-489.

Nunes, G.S., P. Skladal, H. Yamanaka, and D. Barcelo. 1998. Determination of carbamate residues in crop samples by cholinesterase-based biosensors and chromatographic techniques. Anal. Chim. Acta 362:59-68.

Odaci, D., S. Timur, and A. Telefoncu. 2004. Carboxyl esterase-alcohol oxidase based biosensor for the aspartame determination. Food Chem. 84:493-496.

Ohashi, E., and I. Karube. 1993. Sensors for the food industry. Food Control 4:183-188.

Olschewski, H., A. Erlenkötter, C. Zaborosch, and G.C. Chemnitius. 2000. Screen-printed enzyme sensors for l-lysine determination. Enzyme Microb. Technol. 26:537-543.

Palmisano, F., R. Rizzi, D. Centonze, and P.G. Zambonin. 2000. Simultaneous monitoring of glucose and lactate by an interference and cross-talk free dual electrode amperometric biosensor based on electropolymerized thin films. Biosens. Bioelectron. 15:531-539.

Panfili, G., P. Manzi, D. Compagnone, L. Scarciglia, and G. Palleschi. 2000. Rapid assay of choline in foods using a microwave hydrolysis and a choline biosensor. J. Agr. Food Chem. 48:3403-3407.

Parellada, J., A. Narváez, M.A. López, E. Domínguez, J.J. Fernández, V. Pavlov, and I. Katakis. 1998. Amperometric immunosensors and enzyme electrodes for environmental applications. Anal. Chim. Acta 362:47-57.

Park, I.-S., Y.-J. Cho, and N. Kim. 2000. Characterization and meat freshness application of a serial threeenzyme reactor system measuring ATP-degradative compounds. Anal. Chim. Acta 404:75-81.

Patel, P.D. 2002. (Bio)sensors for measurement of analytes implicated in food safety: a review. Trends Anal. Chem. 21:96-115.

Pérez Pita, M.T., A.J. Reviejo, F.J. Manuel de Villena, and J.M. Pingarrón. 1997. Amperometric selective biosensing of dimethyl- and diethyldithiocarbamates based on inhibition processes in a medium of reversed micelles. Anal. Chim. Acta 340:89-97.

Prodromidis, M.I., S.M. Tzouwara-Karayanni, M.I. Karayannis, and P.M. Vadgama. 1997. Bioelectrochemical determination of citric acid in real samples using a fully automated flow injection manifold. Analyst 122:1101-1106. 
Ramanathan, K., B.R. Jönsson, and B. Danielsson. 2001. Sol-gel based thermal biosensor for glucose. Anal. Chim. Acta 427:1-10.

Rasooly, A. 2001. Surface plasmon resonance analysis of Staphylococcal enterotoxin B in food. Food Protec. 64:37-43.

Rogers, K.R., and M. Mascini. 1998. Biosensors for field analytical monitoring. Field Anal. Chem. Technol. 2:317-331.

Saidman, S.B., M.J. Lobo-Castañón, A.J. MirandaOrdieres, and P. Tuñón-Blanco. 2000. Amperometric detection of D-sorbitol with $\mathrm{NAD}^{+}$-D-sorbitol dehydrogenasse modified carbon paste electrode. Anal. Chim. Acta 424: 45-50.

Sarkar, P., I.E. Tothill, S.J. Setford, and A.P.F. Turner. 1999. Screen-printed amperometric biosensors for the rapid measurement of L- and D-amino acids. Analyst 124:865-870.

Sekine, Y., and E.A.H. Hall. 1998. A lactulose sensor based on coupled enzyme reactions with a ring electrode fabricated from tetrathiafulvalen-tetracyanoquinodimetane. Biosens. Bioelectron. 13:995-1005.

Setti, L., A. Fraleoni-Morgera, I. Mencarelli, A. Filippini, B. Ballarin, and M. Di Biase. 2007. An HRP-based amperometric biosensor fabricated by thermal inkjet printing. Sensor Actuator B- Chem. 126:252-257.

Silber, A., C. Bräuchle, and N. Hampp. 1994. Dehydrogenase-based thick-film biosensors for lactate and malate. Sensor Actuator B- Chem. 18:235-239.

Smyth, A.B., P.C. Talasila, and A.C. Cameron. 1999. An ethanol biosensor can detect low-oxygen injury in modified atmosphere packages of fresh-cut produce. Postharvest Biol. Technol. 5:127-134

Tatsumi, H., H. Katano, and T. Ikeda. 2006. Kinetic analysis of enzymatic hydrolysis of crystalline cellulose by cellobiohydrolase using an amperometric biosensor. Anal. Biochem. 357:257-261.
Tingry, S., C. Innocent, S. Touil, A. Deratani, and P. Seta. 2006. Carbon paste biosensor for phenol detection of impregnated tissue: modification of selectivity by using $\beta$-cyclodextrin-containing PVA membrane. Mater. Sci. Eng. C 26:222-226.

Tombelli, S., and M. Mascini. 1998. Electrochemical biosensors for biogenic amines: A comparison between different approaches. Anal. Chim. Acta 358:277-284.

Tothill, I.E. 2001. Biosensors developments and potential applications in the agricultural diagnosis sector. Comp. Electron. Agr. 30:205-218.

Tsai, H.C., R.A. Doong, H.C. Chiang and K.T. Chen. 2003. Sol-gel derived urease-based optical biosensor for the rapid determination of heavy metals. Anal. Chim. Acta 481:75-84.

Vadiuambal, R., and D.S. Jayas. 2007. Changes in quality of microwave-treated agricultural products: a review. Biosyst. Eng. 98:1-16.

Velasco-García, M.N., and T. Mottram. 2003. Biosensor technology addressing agricultural problems. Review paper. Biosyst. Eng. 84:1-12.

Volpe, G., and M. Mascini. 1996. Enzyme sensors for determination of fish freshness. Talanta 43:283-289

Wilson, G.S., and R. Gifford. 2005. Review biosensors for real-time in vivo measurements. Biosens. Bioelectron. 20:2388-2403.

Xavier, M.P., B. Vallejo, M.D. Marazuela, M.C. MorenoBondi, F. Baldini, and A. Falai. 2000. Fiber optic monitoring of carbamate pesticides using porous glass with covalently bound chlorophenol red. Biosens. Bioelectron. 14:895-905.

Zhang, Z., and R.P. Wilson. 1998. A modified enzymatic assay for quantifying choline in fish tissue and common feed ingredients. J. Agr. Food Chem. 46:3673-3676.

Zinedine, A., J.M. Soriano, J.C Molto, and J. Mañes. 2007. Review on the toxicity, occurrence, metabolism, detoxification, regulations and intake of zearalenone: an oestrogenic mycotoxin. Food Chem. Toxicol. 45:1-18. 


\title{
EFFECT OF PHEROMONE TRAP DENSITY ON MASS TRAPPING OF MALE POTATO TUBER MOTH Phthorimaea operculella (ZELLER) (LEPIDOPTERA: GELECHIIDAE), AND LEVEL OF DAMAGE ON POTATO TUBERS
}

\author{
Patricia Larraín S. ${ }^{*}$, Michel Guillon², Julio Kalazich³ ${ }^{3}$ Fernando Graña ${ }^{1}$, and Claudia Vásquez ${ }^{1}$
}

\begin{abstract}
Potato tuber moth (PTM), Phthorimaea operculella (Zeller), is one of the pests that cause the most damage to potatoes (Solanum tuberosum L.) in both field crops and storage, especially in regions where summers are hot and dry. Larvae develop in the foliage and tubers of potatoes and cause direct losses of edible product. The use of synthetic pheromones that interfere with insect mating for pest control has been widely demonstrated in numerous Lepidoptera and other insect species. An experiment was carried out during the 2004-2005 season in Valle del Elqui, Coquimbo Region, Chile, to evaluate the effectiveness of different pheromone trap densities to capture P. operculella males for future development of a mass trapping technique, and a subsequent decrease in insect reproduction. The study evaluated densities of 10, 20, and 40 traps ha-1 ${ }^{-1}$, baited with $0.2 \mathrm{mg}$ of PTM sexual pheromone, and waterdetergent for captures. Results indicated that larger numbers of male PTM were captured per trap with densities of 20 and 40 traps per hectare, resulting in a significant reduction $(\mathrm{P}<0.05)$ of tuber damage in these treatments compared with the control which used conventional chemical insecticide sprays.
\end{abstract}

Key words: potato tuber moth, Phthorimaea operculella, mass trapping, pheromone.

\section{INTRODUCTION}

The potato tuber moth is a pest which economically affects potato crops, mainly in regions where the climate is hot and dry. The larvae cause direct damage to the tubers by infesting them underground and control using chemical insecticide sprays is difficult with uncertain results.

The use of synthetic sexual pheromones to interfere with reproduction offers a non-traditional way to manage pest control that does not use insecticides. Sexual pheromones are species-specific and highly selective, and since they are not toxic and do not represent health risks to humans and animals, they are valuable tools in integrated pest control management.

The use of pheromone traps for mass trapping is an insect control method that has been sufficiently

\footnotetext{
${ }^{1}$ Instituto de Investigaciones Agropecuarias, Centro Regional de Investigación Intihuasi, Apartado Postal 36/B, La Serena, Chile. *Corresponding author (plarrain@inia.cl).

International Biocontrol Agent Manufacturers' Association IBMA, 13 Avenue du Béarn, 64000 Pau, France. (guillon.ibma@orange fr). ${ }^{3}$ Instituto de Investigaciones Agropecuarias, Centro Regional de Investigación Remehue, $\mathrm{km} 8$ ruta 5 Norte, Osorno, Chile.

Received: 16 June 2008.

Accepted: 07 December 2008.
}

researched (El-Sayed et al., 2006). It interferes with insect mating, reducing the future larvae population and subsequent damage. In order to improve the effectiveness of the captures and make the traps a more reliable tool in management programs, it is necessary to determine the factors that affect their efficiency (Athanassiou et al., 2002; 2003a; 2003b; 2004; 2005; 2007). Traps can also be used with the degree-day calculation method for decisionmaking on the application of insecticides in pest control (Kumral et al., 2005).

The $P$. operculella pheromone has been studied since 1969 by Adeesan et al. who discovered that it was released from a gland located just before the last abdominal segment of the female. Afterwards, research by Fouda et al. (1975), Roelofs et al. (1975), Persoons et al. (1976), Yamoaka et al. (1976), Bacon et al. (1976), Voerman et al. (1977), Voerman and Rothschild (1978), identified, isolated, and synthesized the two main pheromone compounds, finding that combining them attracted the male moths more than each compound taken separately. Bacon et al. (1976) and Raman $(1982 ; 1984)$ also evaluated the most effective rates of these two compounds in the mixture preparation, as well as some techniques to use these compounds in field and storage traps. 
This pheromone is currently available on the market and is related to the mixture of the trans-4, cis7-tridecadienil1-ol-acetate and trans-4, cis7, cis10 tridecatrienil-1-olacetate compounds in a ratio of $1: 1.5$. This mixture is generally commercialized as a rubber device in which the mixture is impregnated in $1 \mathrm{mg}$ doses.

Though there are some control studies of mass trapping and mating disruption of $P$. operculella (Raman, 1982; 1984; Salas et al., 1985; Ortu and Floris, 1989), these techniques are not used and this pest is mainly controlled with broad-spectrum pesticides.

On the other hand, since there are many factors that can affect the effectiveness of these control methods, it is important to conduct studies that confirm the effectiveness of pheromone use as a control technique for specific crop conditions where the moth constitutes an economically important pest. This explains why the objective of this study was to evaluate the effect of different trap densities on the number of male $P$. operculella captured and the effect of these captures on the reduction of damage caused by larvae in tubers produced under agro-ecologic conditions in the coastal zone of the Coquimbo Region, Chile.

\section{MATERIALS AND METHODS}

During the 2004-2005 season, a massive trapping trial of male potato tuber moth (PTM) was conducted using pheromones in different densities of traps per area. The trial was carried out in El Romero sector (29 53' S; $71^{\circ} 07^{\prime}$ W), La Serena, Coquimbo Region, Chile, using a randomized complete block design with four replications. The area of the experimental plots was $4000 \mathrm{~m}^{2}$.

Sowing took place on 30 October 2004 in an area of approximately 13 ha. Nine hectares were sown with certified daughter seed of the Asterix variety, whereas the remaining hectares were sown with Cardinal potato seed.

The trial was fertilized with $\mathrm{N}, \mathrm{P}_{2} \mathrm{O}_{5}$, and $\mathrm{K}_{2} \mathrm{O}$ in doses of 150,120 , and $60 \mathrm{~kg} \mathrm{ha}^{-1}$, respectively. Mancozeb $1.6 \mathrm{~kg}$ a.i. ha-1 (Mancozeb $80 \%$ WP) fungicide was applied during cultivation to control late blight (Phytophthora infestans). Linuron $1 \mathrm{~kg}$ a.i. ha ${ }^{-1}$ (Linurex $50 \mathrm{WP}$ ) was initially applied to control weeds, but these were later controlled manually. Furrows were irrigated every 7 days. Harvest took place between 31 January and 4 February 2005.

Three trap densities were evaluated with the sexual pheromone of $P$. operculella: trans-4,cis-7-tridecadieno1-ol-acetato and trans-4,cis-7,cis-10 tridecatrieno-1-olacetato in a ratio of $1: 1.5$, and $0.2 \mathrm{mg}$ dose per trap in accordance with the results obtained by Larraín et al. (2007). The trap densities evaluated were 10, 20, and 40 traps ha $^{-1}$ in plots untreated with insecticides. Treatments were distributed within each plot, with $35 \mathrm{~m}$ between plots and a minimum of $5 \mathrm{~m}$ between traps (40 traps ha-1) (Figure 1). These distances were selected in order to avoid the effect between treatments with distinct trap densities, and considering the results of Cameron et al. (2002), who studied the activity of $P$. operculella with entomologic nets and pheromones, finding that adult activity declined at distances of 20 and $40 \mathrm{~m}$ from a release point.

The number of traps used in the trial area corresponding to the 10,20 , and 40 trap ha $^{-1}$ densities were 4,8 , and 16 treatments, respectively, with a total of 112 traps in the trial. The traps were all assembled in the same way as established by Larraín et al. (2007), using 5 L capacity plastic drums containing $2 \mathrm{~L}$ of water with $0.2 \%$ detergent. The dispenser with $0.2 \mathrm{mg}$ of pheromone per trap was supplied by Agrisense-BCS (Pontypridd, South Wales, UK).

\section{Evaluations}

All traps were set up on 6 December 2004. Starting on that date and until harvest, a weekly count checked the number of male moths captured in all the traps of each plot. At that moment, an $80 \mathrm{~kg}$ sample of tubers from a $25-30 \mathrm{~m}^{2}$ area was taken. This sample was taken from the center of each $4000 \mathrm{~m}^{2}$ plot. Four plots of the same area were selected as controls, chosen randomly in the same field, at a distance beyond the influence of the pheromone. Due to the high insect pressure during the season, these plots were managed by the farmer who had to spread eight applications using a permetrine (Pounce ${ }^{\mathrm{R}}$ ) and methamidophos (MTD $600 \mathrm{SL}$, ANASAC, Chile) mixture in doses of $1 \mathrm{~L}$ and $200 \mathrm{~cm}^{3} \mathrm{ha}^{-1}$, respectively.

The damage caused by $P$. operculella was evaluated in all tubers of the samples. The number of undamaged tubers was counted and the percentage of moth damage was calculated in each treatment.

Data from the number of captures and the percentage of damaged tubers was analyzed using a variance analysis (ANOVA) with $5 \%$ probability and the means were compared by using a multiple comparison test with a Least Significant Difference (LSD). The statistical software used was SAS 8.0 for Windows.

\section{RESULTS AND DISCUSSION}

\section{Effect of trap density on captures}

P. operculella captures increased as the trap density increased (Table 1). Densities of 20 and 40 traps ha $^{-1}$ captured a significantly higher number $(\mathrm{P}<0.05)$ of males than the 10 traps ha ${ }^{-1}$ density. However, between the higher density traps (20 and 40 traps ha-1), the mean of males captured was not significantly different $(\mathrm{P} \geq 0.05)$. The mean of males captured per hectare indicates that approximately 


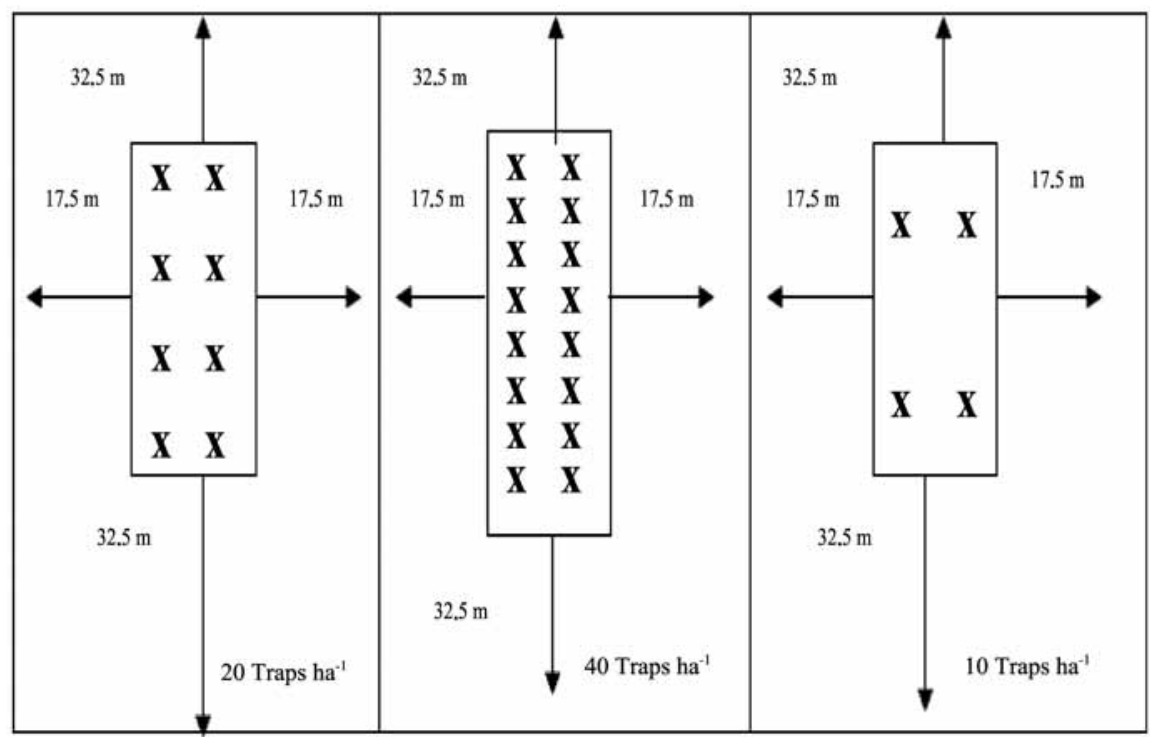

Figure 1. Distribution of treatments in trap density trial. El Romero 2004-2005.

108588 and 90173 males ha $^{-1}$ were captured with densities of 40 and 20 traps $h^{-1}$, respectively (Table 1 ). These results were higher than those obtained by Raman (1988) in Lima, Peru, who captured 92000 male P. operculella, but in $112 \mathrm{~d}$ with a density of 42 traps ha ${ }^{-1}$.

These differences could be due to various factors, such as the pressure of the male moth population in relation to its location, and trap characteristics (type, size, and pheromone dose per trap). Raman (1988) used a standard capsule from Centro Internacional de la Papa (CIP) (International Potato Center) with a 1 $\mathrm{mg}$ dose that was less attractive than the $0.2 \mathrm{mg}$ used in this trial according to the results of Larrain et al. (2007).

On the other hand, Ortu and Floris (1989) increased to 84 traps ha $^{-1}$, and observed a drastic reduction in captures, indicating that with this density, the sexual confusion of $P$. operculella could start to be effective.

\section{Tuber damage by moths}

Damage caused by $P$. operculella larvae in the tubers was significantly higher $(\mathrm{P}<0.05)$ with the control using insecticide treatment (51\% damaged tubers) than in the

Table 1. Mean of Phthorimaea operculella males captured in the 2004-2005 crop season.

\begin{tabular}{cc}
\hline $\begin{array}{l}\text { Treatment } \\
\left(\mathbf{N}^{\circ} \text { traps ha- }^{-1}\right)\end{array}$ & $\begin{array}{c}\text { Number of males captured } \\
\text { (64 days) }\end{array}$ \\
\hline 40 & $108588 \mathrm{a}$ \\
20 & $90173 \mathrm{a}$ \\
10 & $54864 \mathrm{~b}$ \\
Coefficient of variation, \% & 17.5 \\
\hline
\end{tabular}

plots with different densities of pheromone traps evaluated (Table 2).

In accordance with the results obtained by Araya et al. (2000), the potato tuber moths in La Serena, Chile, were less susceptible to methamidophos than populations evaluated in other regions in this country. However, no resistance was noted, so failure of the control could be due to the difficulty of insecticides to reach the insects once they are underground or inside the tubers, and also probably due to a higher mortality of the natural enemies of $P$. operculella caused by the synergetic effect of two broad-spectrum action insecticides.

On the other hand, in plots treated with pheromones, the highest rate of tuber damage (30\%) was obtained with the lowest density of 10 traps $\mathrm{ha}^{-1}$, and less captures. It is possible to emphasize that the damage was similar to that obtained in plots with 40 traps per hectare (25\%), where captures almost doubled compared to 10 traps $\mathrm{ha}^{-1}$ (Table 2). This aspect should be clarified with new studies where more data will be obtained to allow the analysis and establishment of a relation between the male captures and the tuber damage caused by the moth.

Raman (1988) observed minor damage that reached $19 \%$ with lower captures and a similar trap density, though factors such as varietal susceptibility, temperatures during the months of capture, pheromone dose per trap, and type of trap do not allow the comparison of these results.

In plots with moderate density of 20 traps ha- ${ }^{-1}$ with pheromones, minor damage was found with $18.3 \%$ of the tubers affected and significant differences $(\mathrm{P}<0.05)$ compared to the lesser density evaluated in 10 traps ha ${ }^{-1}$ (Table 2). 
Previous results indicate that the control of P. operculella with the insecticides most used in the Valle del Elqui, Chile, is inadequate since the number of tubers damaged was higher than 50\% with eight applications (Table 2). This entails a high economic cost for the farmer and generates environmental damage since insecticides are applied excessively, for example, methamidophos, which is one of the most toxic of the organic phosphate group and classified as an extremely dangerous toxicological category.

This is the first study that analyzes the potential use of mass trapping with sexual pheromones as a direct control method of $P$. operculella in Chile. The results reflect that the use of this technique constitutes a tool which can significantly reduce the number of males with a subsequent decrease in potato tuber moth larvae, resulting in a significantly lower tuber damage rate in the area within pheromone influence.

Table 2. Mean percentage of tubers damaged by Phthorimaea operculella in different pheromone trap densities and control (pesticide management).

\begin{tabular}{lc}
\hline $\begin{array}{l}\text { Treatment } \\
\left.\text { traps ha }^{-1}\right)\end{array}$ & $\begin{array}{c}\text { Mean of tuber damage } \\
\text { (\%) }\end{array}$ \\
\hline Control & $51 \mathrm{a}$ \\
10 & $30 \mathrm{~b}$ \\
20 & $18 \mathrm{c}$ \\
40 & $25 \mathrm{bc}$ \\
Coefficient of variation, \% & 19.4 \\
\hline
\end{tabular}

\section{CONCLUSIONS}

Twenty traps per hectare appear to be the most effective and convenient trap density to use in a potato tuber moth integrated management program. No significant difference was shown in male capture and tuber damage between this density and the higher trap density trials, therefore the lower density trap pattern proved to be as efficient and more economical.

\section{RESUMEN}

Efecto de la densidad de trampas de feromona en la captura masiva de machos de polilla de la papa, Phthorimaea operculella (Zeller) (Lepidoptera: Gelechiidae), y en el nivel de daño a los tubérculos. La polilla de la papa, Phthorimaea operculella (Zeller), es una de las plagas que causan mayor daño a la papa (Solanum tuberosum L.), tanto a los cultivos en campo como a los tubérculos almacenados, especialmente en zonas de climas cálidos y secos. Las larvas de este insecto se desarrollan en el follaje y tubérculos de papa causando pérdidas directas del producto a comercializar. La utilización de feromonas sintéticas, como una herramienta que interfiere con el apareamiento, ha sido ampliamente demostrada en innumerables especies de polillas y otros insectos. Con el fin de evaluar la efectividad de diferentes densidades de trampas de feromona en la captura de machos de $P$. operculella, para su futura utilización como técnica de trampeo masivo y consecuente disminución de la reproducción del insecto, se realizó un estudio durante la temporada 2004-2005, en el Valle del Elqui, Región de Coquimbo, Chile. Se evaluaron densidades de 10, $20 \mathrm{y}$ 40 trampas ha ${ }^{-1}$ con una carga de $0,2 \mathrm{mg}$ de feromona por trampa, utilizando trampas de agua con detergente para las capturas. Los resultados indican que la mayor captura de machos de polilla de la papa se obtiene con densidades de 20 y 40 trampas ha ${ }^{-1}$, encontrándose también una reducción significativa $(P<0,05)$ del daño en tubérculos en estos tratamientos comparados con el testigo convencional con aspersiones de insecticidas.

Palabras clave: papa, plagas, polilla de la papa, Phthorimaea operculella, capturas masivas, feromonas.

\section{LITERATURE CITED}

Adeesan, C., A.J. Tamhankar, and G.W. Rahalkar. 1969. Sex pheromone gland in the potato tuberworm moth, Phthorimaea operculella. Ann. Entomol. Soc. Am. 62:670-671.

Araya, J., M. Guzmán, y M.A. Guerrero. 2000. Verificación de susceptibilidad de las larvas de la polilla de la papa, Phthorimaea operculella (Zeller), a cuatro insecticidas. Inv. Agr. 20:53-60.

Athanassiou, C.G., N.G. Kavallieratos, S.F. Gakis, L.A. Kyrtsa, B.E. Mazomenos, and F.T. Gravanis. 2007. Influence of trap type, trap colour, and trapping location on the capture of the pine moth, Thaumetopoea pityocampa. Entomol. Exp. Appl. 122:117-123.

Athanassiou, C.G., N.G. Kavallieratos, F.T. Gravanis, N.A. Koukounitsas, and D.E. Rousou. 2002. Influence of trap type, pheromone quantity and trapping location, on the capture of the pink bollworm, Pectinophora gossypiella (Sounders) (Lepidoptera: Gelechiidae). Appl. Entomol. Zool. 37:385-391.

Athanassiou, C.G., N.G. Kavallieratos, E.Th. Kolokytha, and F.T. Gravanis. 2003a. Influence of the simultaneous use of pheromone sources on the capture of Pectinophora gossypiella (Sounders) (Lepidoptera: Gelechiidae) and Helicoverpa armigera (Hübner) (Lepidoptera: Noctuidae) on cotton. p. 1133-1141. In Proceedings of the Third World Cotton Research Conference, Cape Town, South Africa. 9-13 March 2003. Agricultural Research Council-Institute for Industrial Crops, Pretoria, South Africa. 
Athanassiou, C.G., N.G. Kavallieratos, and B.E. Mazomenos. 2004. Effect of trap type, trap color, trapping location and pheromone dispenser on captures of male Palpita unionalis (Hübner) (Lepidoptera: Pyralidae). J. Econ. Entomol. 97:321-329.

Athanassiou, C.G., N.G. Kavallieratos, and B.E. Mazomenos. 2005. Population dynamics of Palpita unionalis (Hubner) (Lepidoptera: Pyralidae) in central and northen Greece. IOBC/WPRS Bull. 28:117-120.

Athanassiou, C.G., N.G. Kavallieratos, N.E. Palyvos, and C.Th. Buchelos. 2003b. Evaluation of the multisurface trap on the capture of Ephestia kuehniella Zeller. Phytoparasitica 31:39-50.

Bacon, O.G., J.M. Seiber, and G. Kennedy. 1976. Evaluation of survey trapping techniques for potato tuberworm with chemical baited traps. J. Econ. Entomol. 69:569-572.

Cameron, P.G., G.P. Walter, A.R. Wallace, and P.J. Wigley. 2002. Movement of potato moth estimated by markrecapture experiments. N.Z. Plant Protect. 55:177181.

El-Sayed, A.M., D.M. Suckling, C.H. Wearing, and J.A. Byers. 2006. Potential of mass trapping for long-term pest management and eradication of invasive species. J. Econ. Entomol. 99:1550-1564.

Fouda, H.G., J.N. Seiber, and O.G. Bacon. 1975. A potent sex attract for the potato tuberworm moth. J. Econ. Entomol. 68:423-427.

Kumral, N.A., B. Kovanci, and B. Akbudak. 2005. Pheromone trap catches of the olive moth, Prays oleae (Bern.) (Lep., Plutellidae) in relation to olive phenology and degree-day models. J. Appl. Entomol. 129:375-381.

Larraín, P., M. Guillon, J. Kalazich, F. Graña, y C. Vásquez. 2007. Efectividad de distintas dosis de feromona sexual de Phthorimaea operculella (Zeller) (Lepidoptera: Gelechiidae) en la captura de machos de polilla. Agric. Téc. (Chile) 67:431-436.
Ortu, S., and I. Floris. 1989. Preliminary study on the control of Phthorimaea operculella (Zeller) (Lepidoptera: Gelechiidae) on potatoes crops in Sardinia. Difesa-delle-Piante 12:1-2, 81-88.

Persoons, C.J., S. Voerman, P.E.J. Verwiel, F.J. Ritter, W.J. Nooijen, and A.K. Minks. 1976. Sex pheromone of the potato tuberworm moth Phthorimaea operculella: isolation, identification and field evaluation. Entomol. Exp. Appl. 20:289-300.

Raman, K.V. 1982. Field trials with the sex pheromone of the potato tuberworm (Lepidoptera: Gelechiidae). Environ. Entomol. 11:367-370.

Raman, K.V. 1984. Evaluation of a synthetic sex pheromone funnel trap for potato tuberworm moths (Lepidoptera: Gelechiidae). Environ. Entomol. 13:6164.

Raman, K.V. 1988. Control of potato tuber moth Phthorimaea operculella with sex pheromones in Perú. Agric. Ecosyst. Environ. 21:85-89.

Roelofs, W.L., J.P. Kochansky, and R.T. Cardé. 1975. Sex pheromone of the potato tuberworm moth Phthorimaea operculella. Life Sci. 17:699-706.

Salas, J., A. Parra, y C. Álvarez. 1985. Evaluación preliminar de la feromona sexual sintética del minador grande de la hoja del tomate Phthorimaea operculella en la captura de machos. Agron. Trop. 35:139-144.

Voerman, S., and G.H.L. Rothschild. 1978. Synthesis of the potato tuberworm moth Phthorimaea operculella (Zeller) (Lepidoptera: Gelechiidae): and field experience with them. J. Chem. Ecol. 4:531-542.

Voerman, S., A.K. Minks, and C.J. Persoons. 1977. Elucidation of the sex pheromone systems of the potato tuber worm moth Phthorimaea operculella (Zeller) (Lepidoptera: Gelechiidae): a short review. Potato Res. 20:123-126.

Yamoaka, R., H. Fuakami, and S. Ischii. 1976. Isolation and identification of the female sex pheromone of the potato tuberworm moth Phthorimaea operculella (Zeller). Agric. Biol. Chem. 40:1971-1977. 


\title{
RHIZOGENIC INDUCTION IN ADULT Juglans regia L. cv. SERR TISSUE INDUCED BY INDOLE BUTYRIC ACID AND Agrobacterium rhizogenes
}

\author{
Manuel Sánchez-Olate ${ }^{1 *}$, Patricia Sáez ${ }^{1}$, and Darcy Ríos ${ }^{1}$
}

\begin{abstract}
The in vitro introduction of adult walnut (Juglans regia L.) tissue represents an opportunity to clone elite genotypes whose selection occurs in advanced ontogenic states. With the purpose of developing a protocol to allow mass propagation of valuable genotypes from adult material, a comparison was made between two root induction systems of walnut microshoots of the fourth subculture of adult walnut tissue of an in vitro introduction program previously reinvigorated through traditional grafting. Rhizogenic induction by indole-3-butyric acid (IBA) and Agrobacterium rhizogenes was used. The rhizogenic process was analyzed in two phases for both auxinic (T1: $3 \mathrm{mg} \mathrm{L}^{-1} \mathrm{IBA}$; T2: $5 \mathrm{mg} \mathrm{L}^{-1}$ IBA) and A. rhizogenes inductions (T3: A-477; T4: A-478). The first phase of root induction was during 3 days in the dark while the second phase, root manifestation, was 27 days. Rooting percentage was evaluated and the induced root systems characterized (number, length, diameter, and root insertion zone) in all the procedures. The best rooting results were obtained in T2, although the response obtained with A. rhizogenes didn't differ from the T1 response. This appears to be an increasingly interesting methodology for adventitious rhizogenesis in this species.
\end{abstract}

Key words: rooting, microshoots, adult material, Agrobacterium rhizogenes.

\section{INTRODUCTION}

The application of walnut regeneration methods by means of in vitro culture of embryos has allowed overcoming the barriers for the large scale production of crops, such as low percentage of seed germination and long propagation cycles. In the first case, between two and three months of stratification are required, whereas the propagation cycles are related to obtaining appropriate size patterns for grafting and the development of commercial specimens in a period of two to three years. With respect to the formation of microplants by means of in vitro culture, plants with intact roots, shoots, and leaves have been obtained in distinct culture mediums (Leslie and McGranahan, 1992; Driver y Kuniyuki, 1994; Sánchez-Olate et al., 1997; Fernández et al., 2000), finding that roots were more robust and developed than leaves (Kaur et al., 2006). However, there is no record of the utilization of this technique in adult $J$. regia material which is of vital importance for the development of a massive propagation program, taking into consideration that it is a recalcitrant species (Preece et al., 1989; Leslie and McGranahan, 1992; Caboni et al., 1996; Rodríguez

${ }^{1}$ Universidad de Concepción, Facultad de Ciencias Forestales, Casilla 160 C, Concepción, Chile.

"Corresponding author (msanche@udec.cl).

Received: 08 January 2008.

Accepted: 13 May 2008. et al., 2005) with a reduced morphogenetic capacity in the adult phase due to a complex metabolic and tissular system (Sánchez-Olate et al., 2002). These characteristics make it necessary to search for reinvigoration techniques appropriate to this species, such as the severe pruning applied to Corylus avellana L. (Sánchez-Olate et al., 2004) and Pinus radiata D. Don (Materán et al., 2008).

In vitro reinvigoration techniques have been applied which allow the establishment of a propagation system on a larger scale from adult material selected for productivity. However, the presence of various phenol endogenous compounds, including allelopathic naphthoquinone called juglone, which interfere with cell growth (Fernández et al., 2000) have made it difficult to obtain successful results. It has been suggested that the presence of polyamines, endogenous juglone, or the continuity of sclerenchymatic cylinders contained in the phloem of plant material inhibits root formation (Günes, 1999). This would explain the fact that only high rhizogenic rates have been obtained from material of embryonic origin (Leslie and McGranahan, 1992). This fact restricts the advantages that elite genotype cloning represents where selection occurs in advanced ontogenic states with a high complexity at both the metabolic and tissular levels (Sánchez-Olate et al., 2002).

Microshoots of micro-propagated in vitro J. regia from isolated embryos have been rooted using auxins such as naphthalene acetic acid (NAA) and indole butyric 
acid (IBA) (Ripetti et al., 1994), genetic transformation with Agrobacterium tumefaciens (McGranahan et al., 1988), and inoculation with A. rhizogenes (Caboni et al., 1996). The latter permits the induction of adventitious roots in the infection zone due to the transfer of genetic information of a portion of (T-DNA) of Ri (Root inducing) plasmid from the bacteria to the plant genome (Strobel and Nachmias, 1988). Caboni et al. (1996) used this method to achieve rooting rates between 52 and $68 \%$ in embryonic $J$. regia cv. Sorrento microshoots that were successfully transferred ex vitro. At this moment, no results using adult material have been reported.

The results obtained with Agrobacterium have been related to a synergy between the auxinic (IBA) concentration and the $A$. rhizogenes infection which is expressed by a possible response of living plant cells contiguous to the dead cells infected with the bacteria. The living cells would transmit diffuse signals to other healthy cells that are capable of initiating the rhizogenesis process (Falasca et al., 2000). According to Vahdati et al. (2002), the rol genes derived from the T-DNA of A. rhizogenes are involved in changing the following characteristics in the transformed plants: rol A: wrinkled leaves, condensed inflorescences, increment in the size of the stigma and large flowers; rol B: increments the rooting potential as a result of increasing sensitivity to the tissue auxins, alters the morphology, and increases flower size; rol C: reduces internode length, produces flowering abnormalities, and increments ramification; rol D: causes dwarfism and early blooming. However, in transgenic 5-year old walnut trees transformed by the rol ABC genes, no differences were found in the growth habit of shoots and roots (Vahdati et al., 2002).

The effect of indole butyric acid and two wild strains of Agrobacterium rhizogenes on rhizogenic induction in Juglans regia microshoots was studied since the aim was to develop a protocol allowing massive propagation from adult material.

\section{MATERIALS AND METHODS}

\section{Plant material}

Caulinar portions of adult material were used and obtained from epicormic shoots of reinvigorated material by grafting $J$. regia cv. Serr on J. nigra. This was maintained in the fourth subculture on a DKW (Driver and Kuniyuki, 1994) proliferation medium with $\mathrm{pH} 5.8$, supplemented with sucrose (3\%), benzylaminopurine (BAP) $\left(1 \mathrm{mg} \mathrm{L}^{-1}\right)$, IBA $\left(0,01 \mathrm{mg} \mathrm{L}^{-1}\right)$, and gelled with agar agar $\left(7 \mathrm{~g} \mathrm{~L}^{-1}\right)$ in photoperiodic environmental conditions of $16 \mathrm{~h}, 25 \pm 1^{\circ} \mathrm{C}$ during the day, $22 \pm 1^{\circ} \mathrm{C}$ during the night, $60 \%$ relative humidity, and light intensity of $40 \mu \mathrm{E}$ $\mathrm{m}^{-2} \mathrm{~s}^{-2}$, as reported by Sánchez-Olate et al. (2002).

\section{Rooting assay}

The rhizogenic process was analyzed for auxinic induction (T1: $3 \mathrm{mg} \mathrm{L}^{-1} \mathrm{AIB}$; T2: $\left.5 \mathrm{mg} \mathrm{L}^{-1} \mathrm{IBA}\right)$ and $A$. rhizogenes induction (T3: A-477; T4: A478) in two phases. The first phase was root induction in the dark for 3 days, and the second 27-day phase was known as root manifestation.

\section{Rooting induced by IBA}

Microshoots, $3 \mathrm{~cm}$ long, were handled using the rooting methodology described by Ripetti et al. (1994), and tested in two concentrations of exogenous IBA ( 3 and $5 \mathrm{mg} \mathrm{L}^{-1}$ ) in an MS (Murashige and Skoog, 1962) medium with 25\% (MS1/4) macronutrients. An induction phase of 3 days was maintained in the dark at a temperature of $25 \pm$ $1{ }^{\circ} \mathrm{C}$ during the day, $22 \pm 1{ }^{\circ} \mathrm{C}$ during the night, and $60 \%$ relative humidity. Once the induction phase was finalized, the microshoots were transferred to the root manifestation phase of 27 days in a 16:8 photoperiod in a DKW (Driver and Kuniyuki, 1994) medium with 25\% (DKW1/4) macronutrients mixed with vermiculite $(220 / 250 \mathrm{v} / \mathrm{v})$, and solidified with gelrite $\left(\right.$ Phytagel, Sigma $\left.{ }^{\circledR}\right)$.

\section{Rooting induced by $A$. rhizogenes}

Microshoots, $3 \mathrm{~cm}$ long, were inoculated in their basal portion with A-477 and A-478, wild strains of A. rhizogenes from the Valencia, Spain collection (Dawson et al., 1990). The reactivation of bacterial growth was carried out with an aliquot in a microbiological beaker and by resuspending it in a $2 \mathrm{~mL}$ liquid medium of YMB (Yeast Medium Basal) (Hooykaas et al., 1977), and shaking it during $48 \mathrm{~h}$ at $300 \mathrm{rpm}$ and $25-27{ }^{\circ} \mathrm{C}$. Subsequently, $100 \mu \mathrm{L}$ of aliquots were taken from the initial bacterial suspension to be resuspended in $10 \mathrm{ml}$ capacity tubes containing $2 \mathrm{~mL}$ of liquid YMB medium to reapply the initial treatment. Finally, $100 \mu \mathrm{L}$ of aliquots were cultivated in a solidified medium with agar $\left(8 \mathrm{~g} \mathrm{~L}^{-1}\right)$ on Petri dishes with $10 \mathrm{~mL}$ of medium maintained at 28 ${ }^{\circ} \mathrm{C}$ during $24 \mathrm{~h}$ in inverted position to avoid evaporation.

Once the colonies were developed, a $100 \mathrm{~mL}$ Erlenmeyer flask containing $20 \mathrm{~mL}$ of liquid YMB medium was inoculated with an inoculation loop by shaking it at $300 \mathrm{rpm}$ at $25-27^{\circ} \mathrm{C}$ for $48 \mathrm{~h}$. Subsequently, the solution was placed on a sterile Petri dish in order to proceed with the inoculation of the microshoots obtained from the proliferative chains. The basal inoculation of the microshoots was carried out by submerging them during $3 \mathrm{~min}$ in a bacterial solution after eliminating the basal axillary buds and cutting them in $1 \mathrm{~cm}$ lengths to increase the infection area. The microshoots were immediately placed on sterile filter paper arranged in a laminating flow chamber to dry and afterwards cultivate them in glass containers with $25 \mathrm{~mL}$ of MS1/4 medium during three days 
in a dark chamber at a temperature of $25 \pm 1{ }^{\circ} \mathrm{C}$ during $16 \mathrm{~h}, 22 \pm 1{ }^{\circ} \mathrm{C}$ during $8 \mathrm{~h}$, and $60 \%$ relative humidity. At the end of the induction phase (3 days in the dark), the microshoots were cultivated in a DKW $1 / 4$ medium mixed with vermiculite $(200 / 250 \mathrm{v} / \mathrm{v})$, and solidified with gelrite $\left(2,5 \mathrm{~g} \mathrm{~L}^{-1}\right.$ of Phytagel, Sigma $\left.{ }^{\circledR}\right)$ to which 300 $\mu \mathrm{g} \mathrm{mL}^{-1}$ of Cephotaxime (Claforan ${ }^{\circledR} 1 \mathrm{~g}$, Roussel Ibérica, S.A.) were added to control bacterial development. The environmental conditions corresponded to a $16 \mathrm{~h}$ photoperiod of light during 27 days at a temperature of $25 \pm 1^{\circ} \mathrm{C}$ during the day, $22 \pm 1{ }^{\circ} \mathrm{C}$ during the night, and $60 \%$ relative humidity.

The experimental design was completely random with four replications. The experimental unit corresponded to a container with four microshoots each measuring $2.5 \mathrm{~cm}$. At the end of the manifestation period the microshoots were extracted and carefully washed to eliminate the substrate adhering to the roots. The treatments were compared by evaluating the percentage of rooting and the induced radicular systems, contrasting them statistically with ANOVA. Significant differences were identified with the Tukey multiple comparison test with 95\% probability (Steel and Torrie, 1985).

\section{RESULTS}

Results indicated that it is possible to induce adventitious rhizogenesis in microshoots originating from adult material (Table 1) when they are partially reinvigorated by grafting. The rates of rooting and the quality of the resulting radicular system are similar to those obtained in microshoots of embryonic origin (SánchezOlate, 1997), but with different responses depending on the inductor used.

As occurs with material of embryonic origin, results showed a close relationship between callogenesis and rhizogenesis. In each treatment, as the percentage of callogenic tissue increased, a smaller number of explants rooted (Table 1). Even with the best rooting results obtained in T2 (Table 1), the response to A. rhizogenes (T3 and T4) did not differ from T1. Hence, it could become an increasingly interesting method for adventitious rhizogenesis in this species since observed rhizogenic rates greatly exceeded the results reported by Sierra (2002) in cutting rooting of the same species (12\%).

By analyzing the number of roots for each microshoot, T2 generated a significantly greater response with respect to T1, T3, and T4. In the latter two, as occurred in the rooting rate, there were no significant differences (Table 1). On the other hand, major differences occurred in the length of the induced radicular system since the $5 \mathrm{mg} \mathrm{L}^{-1}$ application of IBA produced significantly larger roots than in the other treatments for the same manifestation period (Figure 1a and 1b). This led to two hypotheses: a) that the high auxinic concentration forces an accelerated metabolic route toward the synthesis of rhizogenic tissues, or b) that the high auxinic concentration forces a strong initial pulse, the roots are generated in the first hours of manifestation and develop in length over an extended period of time. This second hypothesis coincided with observations made by Ríos et al. (2002) in cotyledonal portions of the same species where it was observed that the rhizogenic induction produced by high auxinic concentrations took place in the first few hours after applying treatment. This resulted in a numerous and longer radicular system with respect to the treatments with lesser concentrations of IBA and greater concentrations of other auxins such as indolacetic acid (IAA) and NAA.

With respect to the induction by A. rhizogenes, the results indicate that this induction agent seems to be a real alternative to rooting of this species, not only because of its easy application, but the acceptable rooting rates achieved (Table 1) and the radicular systems obtained (Figure 1c and 1d). Furthermore, the greatest area of influence of this induction agent, manifested by the appearance of roots in the whole area treated, generated their better distribution in relation to its insertion in the caulinar portion.

The differences between the materials obtained in both $A$. rhizogenes strains basically rested on the fact that T3 obtained longer roots (Figure 1c). Perhaps the most

Table 1. Rhizogenic evaluation induced by indole-3-butyric acid (IBA) and Agrobacterium rhizogenes.

\begin{tabular}{|c|c|c|c|c|c|c|}
\hline Treatment & Callogenesis & Rhizogenesis & $N^{\circ}$ of roots & Root length & Root diameter & $\begin{array}{c}\text { Root insertion } \\
\text { zone }^{1}\end{array}$ \\
\hline & \multicolumn{2}{|c|}{$\%$} & & \multicolumn{2}{|c|}{$-\mathrm{mm}$} & \\
\hline $\mathrm{T} 1$ & $66.7 b$ & $50.0 \mathrm{a}$ & 1.8a & 09a & $1 \mathrm{a}$ & B \\
\hline T2 & 50.0a & $67.5 b$ & $3.1 \mathrm{~b}$ & $18 \mathrm{~b}$ & $2 \mathrm{~b}$ & MB \\
\hline T3 & $90.3 \mathrm{c}$ & 47.7a & 2.3a & 09a & $2 b$ & SMB \\
\hline $\mathrm{T} 4$ & 81.3c & $50.0 \mathrm{a}$ & $2.0 \mathrm{a}$ & 05a & $2 \mathrm{~b}$ & SMB \\
\hline
\end{tabular}

Different letters show significant statistical differences $(\alpha \leq 0,05)$.

${ }^{1}$ Root insertion zone to the shoot. S: superior zone of the portion in contact with the culture medium. M: medium zone. B: basal zone. T1: 3 mg L ${ }^{-1}$ IBA. T2: 5 mg L-1 IBA. T3: A-477. T4: A-478. 

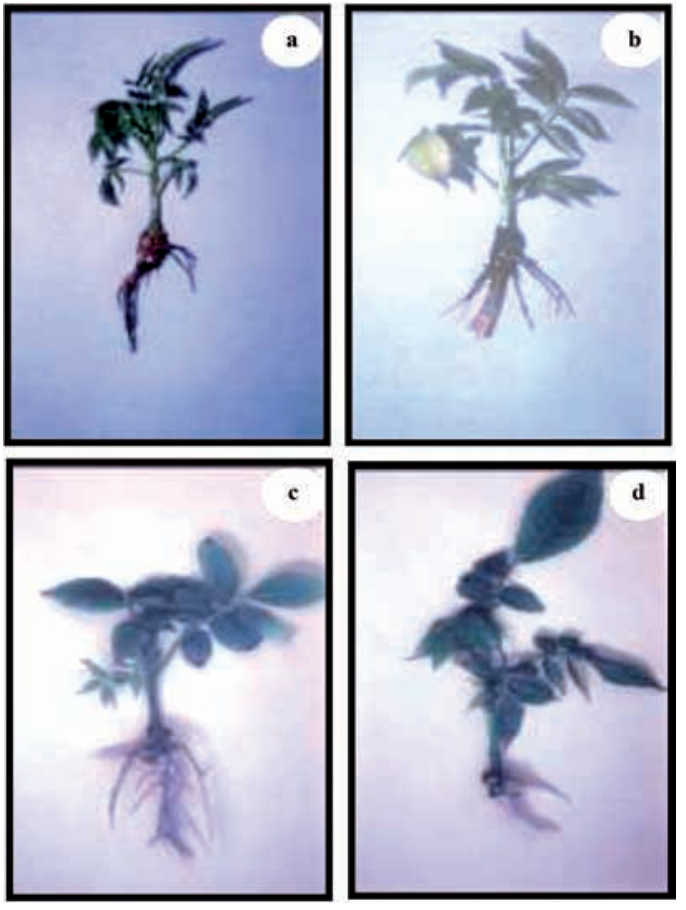

Figure 1. Rooting response in Juglans regia $\mathrm{L}$. cv. Serr microshoots. Rooting in T1 and T2 (a and b), T3 and T4 (c and d), respectively.

important difference was that these roots also rapidly produced a high number of secondary roots exceeding the microplants produced with T4 (Figure 1d), characteristic that favors its subsequent acclimatization ex vitro.

\section{DISCUSSION}

The main problems in the in vitro introduction of $J$. regia adult material were related to the permanent appearance of bacterial contamination of endogenous origin called latent contamination (McGranahan et al., 1988), and the exudation of phytotoxic compounds of phenolic origin (Leslie and McGranahan, 1992). However, the use of reinvigorated material through consecutive pruning or macrografting (Claudot et al., 1992; Leslie and McGranahan, 1992) allowed a decrease in the incidence of this problem on the subsequent culture and development of in vitro explants (McGranahan et al., 1988), originating synthesis processes of plant growth regulators in quantity and quality similar to that obtained in material of embryonic origin (Sánchez-Olate et al., 2002).

Studies related to this topic concur that the apices portion of the microshoots are the most adequate for the rooting phase, whereas multiplication is better with basal segments of microshoots (Ríos et al., 2002; SánchezOlate et al., 2002).
By means of auxinic induction, the rooting rates were greater and the quality of the radicular system gave better results with respect to the number of roots and the zone from which it originated in the microshoot. Rooting was observed at $67.5 \%$ compared to $50 \%$ attained with $A$. rhizogenes, these values being similar to those obtained by Caboni et al. (1996) in embryogenic tissue, condition which can indicate that these bacterial strains have the capacity to improve under organogenic potential imposed by ontogeny (Rodríguez et al., 2005). Infection with $A$. rhizogenesis in the base of the microcuttings was able to induce adventitious radicular systems similar to those obtained in other recalcitrant species (Damiano and Monticelli, 1998; Gutiérrez-Pesce et al., 1998; Hoshino and Mil, 1998; Pérez-Molphe and Ochoa-Alejo, 1998). Abundant adventitious roots were induced in the cut zone, observing characteristics of the transformed roots for the purpose of bacteria plasmid (Tepfer, 1984; Petit et al., 1986; Narasu and Giri, 2000), showing radicular systems distinct from the A-477 and A-478 strains, where the latter appears to have a greater induction capacity than the former, resulting in the particular differences of each strain (Vahdati et al., 2002; Kaur et al., 2006). Furthermore, the transformed roots were able to regenerate transgenic plants or clones that are viable, genetically stable (Narasu and Giri, 2000), and phenotypically normal (SánchezOlate et al., 1997). This could be indicating the interaction between endogenous auxins and the $A$. rhizogenes effect (Falasca et al., 2000).

In spite of the observed differences in the rhizogenic rate obtained via IBA or A. rhizogenes, the use of the bacterial vector can be a powerful tool to reproduce selected cultivars that are advanced in age, or recuperate high-value cultivars in a state of deterioration, given that the results obtained with this inductor were comparable to those obtained with microshoots of embryonic origin (Ripetti et al., 1994; Caboni et al., 1996).

Finally, considering that the commercial importance of $J$. regia generates a high demand for grafted plants with germoplasma quality, and that the results of the grafting programs are significantly less than the rooting percentages achieved in this study, the use of rhizogenic induction agents can mean plant conversion at higher rates than those achieved via traditional grafting.

\section{CONCLUSIONS}

It is possible to attain rooting rates of 50\% from Juglans regia adult material previously rejuvenated through grafting by using auxinic inducers and Agrobacterium rhizogenes. The highest percentage of rooting was obtained in auxinic induction treatments. 


\section{RESUMEN}

Inducción rizogénica en tejido adulto de Juglans regia L. cv. Serr mediada por ácido indol butírico y Agrobacterium rhizogenes. La introducción in vitro de tejido adulto de nogal (Juglans regia L.) representa una oportunidad de clonación de genotipos elite, cuya selección ocurre en estados ontogénicos avanzados. Así, con el objeto de desarrollar un protocolo que permita la propagación masiva de genotipos valiosos a partir de material adulto, se compararon dos sistemas de inducción rizogénica de microtallos de nogal provenientes del cuarto subcultivo de un programa de introducción in vitro de tejido adulto de nogal, previamente revigorizado mediante injerto tradicional. Se utilizó la inducción rizogénica por ácido indol-3-butírico (AIB) y Agrobacterium rhizogenes. El proceso rizogénico se analizó tanto para inducción auxínica (T1: $3 \mathrm{mg} \mathrm{L}^{-1} \mathrm{AIB}$; T2: $5 \mathrm{mg} \mathrm{L}^{-1} \mathrm{AIB}$ ), como para inducción por A. rhizogenes (T3: A-477; T4: A-478), en dos fases. Una primera fase de inducción radicular, con una duración de 3 días en oscuridad; y una segunda fase de 27 días, denominada de manifestación radicular. En todos los tratamientos se evaluó porcentaje de enraizamiento y se caracterizaron los sistemas radiculares inducidos (número, largo, diámetro y zona de inserción de raíces). Los mejores resultados de enraizamiento se obtuvieron en T2; sin embargo, la respuesta obtenida con A. rhizogenes no difiere de aquella lograda en $\mathrm{T} 1$, por lo que pareciera ser una metodología de creciente interés para la rizogénesis adventicia en esta especie.

Palabras clave: enraizamiento, microtallos, material adulto, Agrobacterium rhizogenes.

\section{LITERATURE CITED}

Caboni, E., P. Lauri, N. Tonelli, G. Falasca, and C. Damiano. 1996. Root induction by Agrobacterium rhizogenes in walnut. Plant Sci. 118:203-208.

Claudot, A-C., A. Drouet, and Ch. Jay-Allemand. 1992. Tissue distribution of phenolic compounds in annual shoots from adult and rejuvenated hybrid walnut trees. Plant Physiol. Biochem. 30:565-572.

Damiano, C., and S. Monticelli. 1998. In vitro fruit trees rooting by Agrobacterium rhizogenes wild type infection. Electron. J. Biotechnol. 1:1-7.

Dawson, C., C. Belloch, M.D. García-López, and F. Uruburu. 1990. Spanish type culture collection. Catalogue of strains. $3^{\text {rd }}$ ed. 316 p. University of Valencia, Faculty of Biological Sciences, Valencia, Spain.
Driver, J.A., and A.N. Kuniyuki. 1994. In vitro propagation of Paradox walnut roostock. HortScience 19:507509.

Falasca, G., M. Reverberi, P. Lauri, E. Caboni, A. De Stradis, and M.A. Altamira. 2000. How Agrobacterium rhizogenes triggers de novo root formation in a recalcitrant woody plant: An integrated histological, ultrastructural and molecular analysis. New Phytol. 145:77-93.

Fernández, H., C. Pérez, and R. Sánchez-Tames. 2000. Modulation of the morphogenic potencial of the embryonic axis of Juglans regia by cultural conditions. Plant Growth Regul. 30:125-131.

Günes, T. 1999. An investigation on rooting of Juglans regia L. hardwood cuttings. Turk. J. Bot. 23:367-372.

Gutiérrez, P., P. Taylor, R. Muleo, and E. Rugini. 1998. Somatic embryogenesis and shoot regeneration from transgenic roots of cherry roostock colt (Prunus avium x P. pseudocerasus). Plant Cell Rep. 17:581-585.

Hooykaas, P.J.J., P.M. Klapwijk, M.P. Nuti, R.A. Schilperoort, and A. Rorsch. 1977. Transfer of the A. tumefasciens Ti plasmid to avirulent Agrobacterium and Rhizobium ex planta. J. Gen. Microbiol. 98:477484.

Hoshino, Y., and M. Mil. 1998. Bialaphos stimulates shoot regeneration from hairy roots of snapdragon (Antirrhinum majus L.) transformed by Agrobacterium rhizogenesis. Plant Cell Rep. 17:256-261.

Kaur, R., N. Sharma, K. Kumar, D.R. Sharma, and S.D. Sharma. 2006. In vitro germination of walnut (Juglans regia L.) embryos. J. Hortic. Sci. 109:385-388.

Leslie, C., and G. McGranahan. 1992. Micropropagation of persian walnut (Juglans regia L.). p. 137-150. In Bajaj, Y.P.S. (ed.) Biotechnology in agriculture and forestry. Vol.18. High tech. and micropropagation II. Springer-Verlag, Berlin, Heidelberg, Germany.

Materán, M., M. Vega, M. Sánchez-Olate, K. Sáez, R. Rodríguez, and D. Ríos. 2008. Reactivation of elite Pinus radiata D. Don. plant tissue by in vitro micrografting. Interciencia 33:66-70.

McGranahan, G., C. Leslie, and J.A. Driver. 1988. In vitro propagation of mature Persian walnut cultivars. HortScience 23:220.

Murashige, T., and F. Skoog. 1962. A revised medium for rapid growth and bioassays with tobacco tissue cultures. Physiol. Plant. 15:473-479.

Narasu, M., and A. Giri. 2000. Transgenic hairy roots: recent trends and applications. Biotechnol. Adv. 18:1-22.

Pérez-Molphe, E., and N. Ochoa-Alejo. 1998. Regeneration of transgenic plants of Mexican lime from Agrobacterium rhizogenes-transformed tissues. Plant Cell Rep. 17:591-596. 


\title{
LIFE, SEASONAL CYCLES, AND POPULATION FLUCTUATION OF Hippodamia variegata (GOEZE) (COLEOPTERA: COCCINELLIDAE), IN THE CENTRAL PLAIN OF LA ARAUCANÍA REGION, CHILE
}

\author{
Ramón Rebolledo ${ }^{*}$, Johnny Sheriff ${ }^{1}$, Leonardo Parra1, and Alfonso Aguilera ${ }^{1}$
}

\begin{abstract}
This study was performed on an alfalfa crop located on the central plain of La Araucanía Region, Chile and in the Laboratorio de Entomología Aplicada de la Facultad de Ciencias Agropecuarias y Forestales at the Universidad de La Frontera. Certain aspects of the biology of Hippodamia variegata (Goeze) (Coleoptera: Coccinellidae) were determined, more specifically in relation to its life cycle, seasonality, and population fluctuation. It was established that this coccinellid requires $190.32 \pm 10.2$ degree-days to complete a generation under laboratory conditions. This information along with the field samplings made it possible to calculate that $H$. variegata completes four generations per season in the alfalfa crop (Medicago sativa L.).
\end{abstract}

Key words: life cycle, seasonal cycle, population fluctuation, Hippodamia variegata, Medicago sativa.

\section{INTRODUCTION}

Hippodamia variegata (Goeze) is an active aphid predator used in the biological control of plant lice in cereals and oil plants in diverse countries (Linskii, 1984; Zúñiga, 1985; Zúñiga et al., 1986; Obrycki and Orr, 1990; Shing and Shing, 1994; El-Hag and Zaitoon, 1996; Obrycki, 1998; González, 2006). Its origin is Palearctic, with a cosmopolitan distribution (Krafsur et al., 1996; Franzmann, 2002), and is found in Asia (Kim et al., 1968; Butani, 1972; Hameed et al., 1977; Wu, 1986), Africa (Badawy, 1969; Haile and Megenasa, 1987; Aalbersberg et al., 1988; Saharaoui and Gourreau, 1998), and Europe (Pruszynski and Lipa, 1971; Natskova, 1973; Radwan and Lovei, 1982; García and Ribeiro, 1983; Plaza, 1987; Ferran et al., 1989; Nicoli et al., 1995; Pekín, 1996; Burgio et al., 2006). It was first introduced in Chile in 1967 as a result of the manifestation of the pale green louse of Metopolophium dirhodum (Walk.) gramineae and the dark ear louse of Sitobion avenae (Fabricius) (Rojas, 1980 a; 1980b). H. variegata is found in Chile from the Arica and Parinacota Region to the Los Lagos Region (González, 2006). According to Aguilera et al. (2005, 2006) and Rebolledo et al. (2007), its occurrence is notable in La Araucanía Region and is very abundant. Grigorov

${ }^{1}$ Universidad de La Frontera, Facultad de Ciencias Agropecuarias y Forestales, Casilla 54-D, Temuco, Chile.

*Corresponding author (ramonr@ufro.cl).

Received: 21 December 2007.

Accepted: 25 May 2008.
(1977), Honek (1985) and Rebolledo et al. (2007) state that $H$. variegata prefers herbaceous plants. Nevertheless, Rebolledo et al. (2007) point out that it is possible to find this species in shrubby and arboreous plants.

Hagen (1962) affirms that coccinellids determine their conduct through four fundamental actions: voltinism, dormancy or diapause, migrations, and formation of aggregates (Hagen, 1962; Hodek, 1967). Voltinism (the number of generations per year) varies according to latitude. Hagen (1962) recognizes four types of voltinism: I = one generation; II = two generations; III or IV = three or more generations; IA = one generation whose adults migrate to hibernate.

Diapause is intimately related to voltinism given that the latter is a consequence of the former (Nieto y Mier, 1985). Hagen (1962) states that there are three types of dormancy depending on the season: (1) hibernation (Types with voltinism I, II, and III), (2) estivation and hibernation (Type IIA), (3) estivo-hibernation (Type IA). With regards to the formation of aggregates, this same author points out that this is perhaps the most fascinating phenomenon of the coccinellids. The majority of them have an instinctive tendency to hibernate socially, just as it occurs with established tribes such as Hippodamini and Anisoctictini. H. variegata prefer an aggregation site on mountain tops or close to these (Khan et al., 2007). With respect to the migration phenomenon, Hagen (1962) indicates that the long migratory flights are related to the search for dormancy sites, and that these are associated at the same time with the formation of aggregates. This coccinellid has been studied in the country as regards 
distribution (Arias, 2000) and predatory activity (Grez and Prado, 2000; Grez andVillagrán, 2000). However, there are no data about voltinism and population fluctuation. In La Araucanía Region, $H$. variegata is an abundant species and especially in alfalfa (Medicago sativa L.) (Rebolledo et al., 2007).

In order to complement the previous studies and increase knowledge about its behavior in La Araucanía, it was proposed to determine its life and seasonal (voltinism) cycles, fluctuation, relative abundance, and its possible natural entomophagous enemies.

\section{MATERIALS AND METHODS}

\section{Field work}

Two seasons (1999-2000 and 2000-2001) were required to determine fluctuation and population density of $H$. variegate (in an alfalfa field located in the former Estación Experimental Maipo belonging to the Facultad de Ciencias Agropecuarias y Forestales of the Universidad de La Frontera, located in the urban radius of the city of Temuco (38 $44^{\prime}$ S, $72^{\circ} 35^{\prime}$ W, 100 m.a.s.l.). Breeding of $H$. variegata adults was done with the alfalfa greenbug Acyrthosiphon pisum (Harris).

$H$. variegata adults were periodically collected with entomological nets during October and March in an alfalfa field. Adults were collected in December and were placed in plastic containers measuring $6.5 \mathrm{~cm}$ in height, $5.0 \mathrm{~cm}$ diameter, and covered with tulle.

To determine the relative abundance and population fluctuation between October 1999 and March 2001, the alfalfa field was visited 46 times. The sampling was carried out periodically every $10 \pm 1$ day during the spring, summer, and autumn months, and every $20 \pm 1$ day during the winter months. Each sample consisted in passing 20 times with a standard $30 \mathrm{~cm}$ diameter entomological net over the foliage in a $180^{\circ}$ range, at a regular pace following the methodology proposed by Metcalf and Luckman (1990) and Apablaza and Stevenson (1995). The sampled area was divided into four 1 ha $^{-1}$ quadrants, numbered clockwise to facilitate sampling. Three samples were taken in each quadrant by leaving a minimum distance of $25 \mathrm{~m}$ between each replicate, checking, and registering the collected material. To determine the number of individuals per $\mathrm{m}^{2}$, considering that the width was the amplitude that the net covered in a $180^{\circ}$ horizontal movement and the length as the distance covered in the sample.

\section{Laboratory work}

H. variegata adults collected in the field were moved to a germination chamber (Archiclima, Temuco, Chile) with controlled humidity conditions ( $70 \pm 8 \%$ ), temperature (21 $\pm 2{ }^{\circ} \mathrm{C}$ ), and photoperiod (16:8 light:darkness) to observe their behavior. Following copulation, males and females were separated. The confined adults were controlled daily to register and eliminate the parasitoids from the breeding.

The laboratory study of the $H$. variegate life cycle was initiated by obtaining eggs from the adults collected in December. These were deposited on Petri dishes and were incubated in the germination chamber in the abovementioned conditions. When the eggs hatched, 80 larvae were separated, individually placed on numbered plastic dishes, and named initial breeding or group A. From this initial breeding, 57 adults were obtained from which 28 couples were formed at the beginning of January and separated into two groups of 14 . A subgroup called AI was made up of 14 females that were permanently maintained with a male, and the second subgroup (AII) was formed by the remaining couples, but maintained with the male only during $48 \mathrm{~h}$. Ten eggs were taken from each female which were bred in isolation in order to determine the influence of the male in the oviposition.

To measure the duration of the life cycle during the month of January, 48 individualized larvae were used as group B and obtained from the 10 isolated eggs of each couple. A new group of 40 larvae were chosen randomly from a single emergence date to determine the growth of each larval stage. The measurements were taken and registered every $24 \mathrm{~h}$. Seven larvae from each larval stage were placed in glass containers with $75 \%$ alcohol to subsequently measure the length and width of each one with the help of graph paper. The widest sector of the thorax was used to measure the width, and the length was considered from the top of the head to where the abdomen ends. Furthermore, the width and length of seven pupas, also chosen randomly from groups A and B, were measured

From the individuals used previously, 22 adults were taken to determine their longevity (50\% males and 50\% females), were fed daily with $A$. pisum and observed until the moment of their natural death.

The summation of degree-days required for a generation was established to determine the seasonal cycle of $H$. variegate. The formula proposed by Dinelli (1999) was used to calculate this summation. This value was contrasted with the results obtained during the months of field study allowing to determine the degree-days required for the activation of the adults following their hibernation, and the number of generations that theoretically occurred in the study zone.

The reason to use two groups (A and B) was the fact that these coccinellids were collected in different periods, and hence separate statistical analyses were done. An experimental randomized complete block design was used where each individual corresponded to one replicate. 
The data of the specimens that completed the life cycle (groups A and B) were compared with variance analysis. Then these results were analyzed using appropriate tests to compare the means of two independent samples, whether parametric (t-Student) or nonparametric (U - MannWhitney) (Visauta, 1997; 1998).

\section{RESULTS AND DISCUSSION}

\section{Population fluctuation of $\boldsymbol{H}$. variegata}

The first adults were examined during October and their number varied between seasons for what seemed to be a clear dependence on the particular yearly environmental conditions. They were completely absent during the winter which accounts for their natural behavior to enter diapause or hibernation. The fluctuation during the period under study showed two annual maxima, one on 10 December 1999 (15 specimens) and the second on 6 February 2001 (13 specimens) (Figure 1).

A noticeable increase in population levels occurred at the beginning of autumn, possibly related with the generation that spent the winter in diapause, results which coincided with those obtained by Apablaza and Stevenson (1995) who pointed out that the annual population maxima for coccinellids in alfalfa in the Metropolitana Region took place at the end of March.

\section{Relative abundance of $\boldsymbol{H}$. variegata}

The relative abundance of this insect was $0.17 \pm$ 0.18 adult specimens $\mathrm{m}^{-2}$ with a variation of 0 to 0.68 individuals $\mathrm{m}^{-2}$. The larvae showed a mean relative abundance of $0.16 \pm 0.25$ specimens $\mathrm{m}^{-2}$ fluctuating between 0 and 1 individuals $\mathrm{m}^{-2}$.

\section{Voltinism of $\boldsymbol{H}$. variegata}

$H$. variegata required $190.32 \pm 10.2$ degree-days to complete a generation considering $10{ }^{\circ} \mathrm{C}$ as the threshold temperature, the one recommended for the majority of coccinellids. During the first sampling season (spring 1999-summer 2000), it was difficult to estimate the number of generations due to a generational overlap since larvae and adults were found in the crop at the beginning of the measurements. Taking into account only the degree-days accumulated during October and November, it was estimated that the necessary degrees would be on 28 November to complete a first generation. The second generation would be obtained at the end of December, a third on the first days of February, and a fourth and final generation during the first week of March, going through the winter in diapause as an adult.

In the second season (spring 2000-summer 2001), the exact date was registered when adults first appeared coming out of their diapause. It was estimated that soon after the appearance of posthibernational adults, at the end of September, the first generation in the crop was completed around 10 December, obtaining the second generation during the second half of January, and the third generation at the end of the first half of February (Figure 2).

These results differed from those informed by Kontodimas and Stathas (2005) who indicate that a study carried out in Greece using $H$. variegate as a food source for D. crataegi, completed a total of seven generations between April and November.

$H$. variegata completed four generations during this study under the environmental conditions of the central plain of La Araucanía Region, the first of them with a longer duration with two to two and one half months, whereas

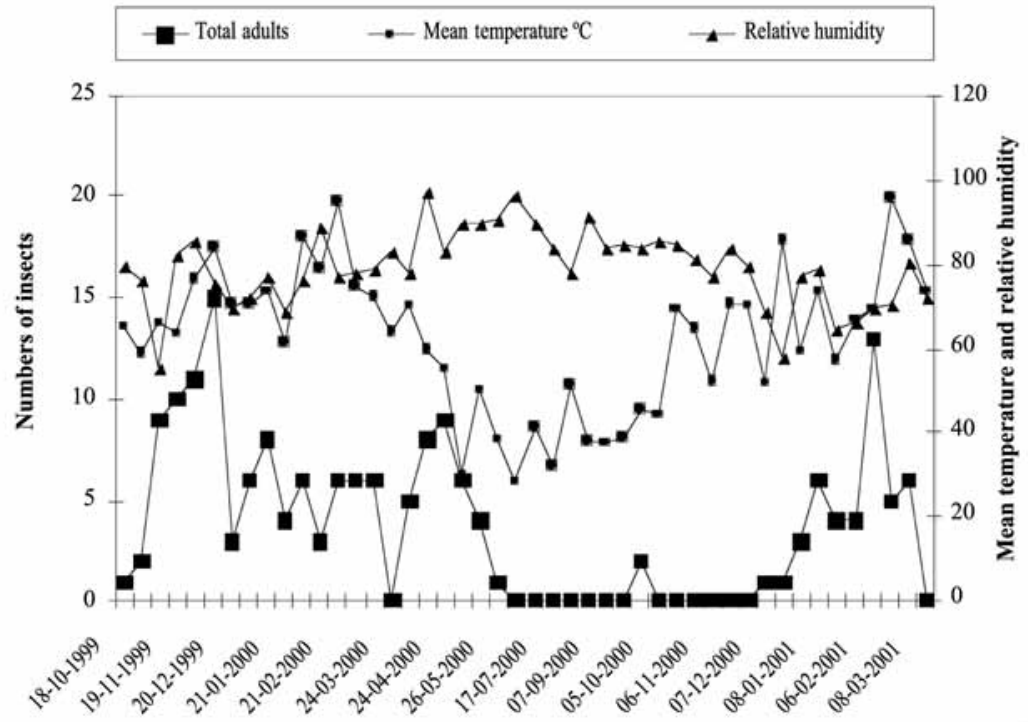

Figure 1. Population fluctuation of Hippodamia variegata adults in the central plain of La Araucanía Region. 


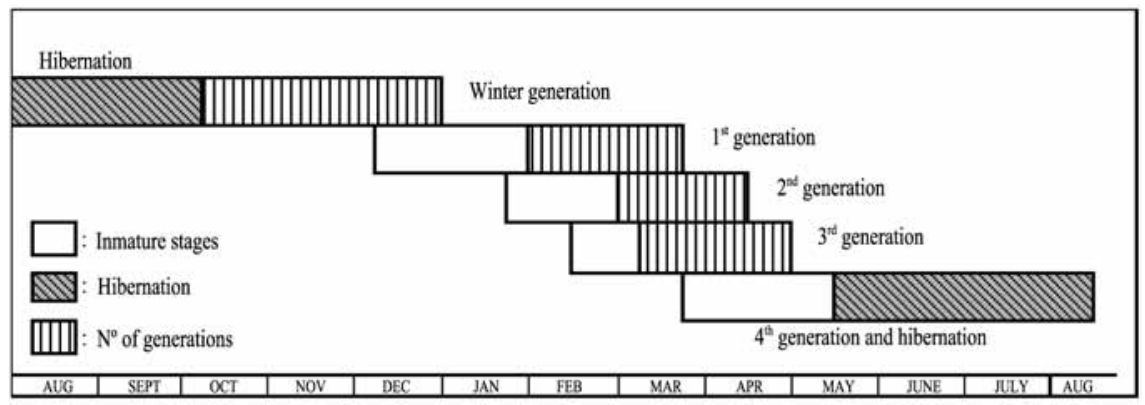

Figure 2. Diagram of Hippodamia variegata voltinism in the central plain of La Araucanía Region (2000-2001).

the rest only took one month that is, they showed a type III voltinism in accordance with that proposed by Hagen (1962). The fact that there was a high overlap between one generation and another is emphasized, fact essentially due to the extensive duration of the adult stage in comparison to the rest of the stages of the life cycle. The polivoltinism observed concurred with Hagen (1962) who pointed out that the environmental conditions are what determine the number of possible generations for coccinellids.

\section{Life cycle of $H$. variegata}

$H$. variegata showed a life cycle of $17.3 \pm 0.93$ days varying in a range of 16 to 21 days. The pupa stage showed the longest duration with $32 \%$ of the life cycle total time, followed by the egg stage and fourth larval stage with $17 \%$ each. There is a discrepancy between this result and the one reported by Badawy (1969) who indicates a mean duration of 10.7 days for the life cycle. Breeding temperature would be a fundamental factor in the rate of preimaginal development according to Hagen (1962), Mitchels and Bateman (1986) who mention a duration of 15.1 days at $25^{\circ} \mathrm{C}$ for the $H$. variegata life cycle, wheras the life cycle decreased to 7.8 days at $30^{\circ} \mathrm{C}$. The difference between this study and those stated by Hagen (1962) and Badawy (1969) can be attributed to the use of other breeding temperatures.

Oviposition, hatching, and incubation period of $\boldsymbol{H}$. variegate eggs

Mating occurred between 2 and 5 days of life, registering the first ovipositions two days later, which is in accordance with that pointed out by Hodek (1967) and Badawy (1969). The oviposition and hatching of the $H$. variegata eggs are shown in Table 1 . With respect to incubation time, it was three days for both groups.

The mean monthly oviposition of $H$. variegata was 223 \pm 103.9 eggs and its frequency reached $4.37 \pm 5.82$ days, a contrast with that reported by Kontodimas and Stathas (2005) who obtained a mean of 956.6 eggs in one breeding of $H$. variegata carried out in Greece. However, that study used Dysaphis crataegi (Kaltenbach) as a food source at a temperature of $25^{\circ} \mathrm{C}$, while the temperature in the present research was $21^{\circ} \mathrm{C}$ and the food was Acyrthosiphon pisum (Harris). The mean of eggs per day of oviposition in the AI subgroup reached $17.58 \pm 6.73$, whereas the groups of eggs attained a mean of $1.59 \pm 0.41$ per day of oviposition. At the same time, subgroup AII showed values similar to those in the previous subgroup with a mean oviposition of $18.73 \pm 6.33$ eggs per day of oviposition, a mean of 1.61 \pm 0.27 groups per day of oviposition. Differences were not significant between the two subgroups.

\section{Duration of $\boldsymbol{H}$. variegata larval stages}

In group A, made up of larvae emerged from the AI and AII subgroups, the mean duration of their development was $7.98 \pm 0.73$, days with a range that fluctuated between 7 and 10 days, with the first and fourth stages having the longest duration with 26 and 32\%, respectively, considering the total development of this stage of the insect, and coinciding with that reported by Badawy (1969). However, it must be pointed out that this author used the aphid Aphis gossypii Glover as food for the $H$. variegata larvae.

The larval stage in group B developed in $10.67 \pm 1.62$ days with a range that varied between 9 and 15 days, coinciding with that found by Mitchels and Flanders (1992), El-Hag and Zaitoon (1996) who determined a mean duration of the larval stage of 11 days using Diuraphis noxia (Mordvilko) and Brevicoryne brassicae (L.) + Rhopalosiphum padi (L.) as food, respectively. This would indicate that the aphid species used did not determine a difference in the duration of the larval stage. The difference in the duration of the larval period between groups A and B would be due to the capture period of the adults (December for group A and January for group B) in which breeding was initiated (Figure 3). The results of the growth of the randomly chosen larval stages are shown in Table 2.

\section{Duration of $\boldsymbol{H}$. variegata pupa stage}

The duration of the pupa stage showed significant differences depending on its origin as group $\mathrm{A}$ or $\mathrm{B}$. 
Table 1. Oviposition and egg hatching percentage of Hippodamia variegata.

\begin{tabular}{lcccc}
\hline Subgroups & $\begin{array}{c}\text { Eggs } \\
\text { day }^{\mathbf{1}}\end{array}$ & $\begin{array}{c}\text { Hatching } \\
\text { mean (\%) }\end{array}$ & $\begin{array}{c}\text { Groups of } \\
\text { eggs day }^{-1}\end{array}$ & $\begin{array}{c}\text { variation } \\
\text { (\%) }\end{array}$ \\
\hline $\mathrm{AI}^{1}$ & $17.58 \pm 6.73$ & $87.81 \pm 5.76$ & $1.59 \pm 0.41$ & $80-100$ \\
$\mathrm{AII}^{2}$ & $18.73 \pm 6.33$ & $81.96 \pm 7.27$ & $1.61 \pm 0.27$ & $72-100$ \\
\hline
\end{tabular}

${ }^{1}$ Permanent couple. ${ }^{2}$ Couple with male only $48 \mathrm{~h}$.

Table 2. Larval instar size of Hippodamia variegata.

\begin{tabular}{lcccc}
\hline State & Mean length $(\mathbf{m m})$ & Range & Mean width $(\mathbf{m m})$ & Range \\
\hline 1 & $1.64 \pm 0.56$ & $1-1.15$ & 0.5 & 0 \\
2 & $2.28 \pm 0.27$ & $2-2.25$ & 1 & 0 \\
3 & $4.07 \pm 0.45$ & $3.5-4.5$ & $2.28 \pm 0.27$ & $2-2.25$ \\
4 & $6.57 \pm 0.44$ & $6-7$ & 2 & 2.25 \\
\hline
\end{tabular}

Group A had a mean duration of $6.27 \pm 0.45$ days with a range of 6 to 7 days, while group B reached a mean of $4.28 \pm 0.61$ days and a variation between 3 and 5 days. Badawy (1969) points out a smaller mean duration value of 2.61 days than the one found in this study, difference based on a higher breeding temperature. The mean size of the randomly chosen pupas was a length of $4.57 \pm 0.45$ mm varying between 4 and $5 \mathrm{~mm}$, and an observed width of $2.57 \pm 0.45$ with a range of 2 to $3 \mathrm{~mm}$.

\section{Longevity of $\boldsymbol{H}$. variegata}

The longevity mean of the adults in both groups was $53.27 \pm 11.93$ days. The females showed longevity of $55.09 \pm 10.85$ days and the males $51.45 \pm 13.03$ days. However, these numbers did not show any significant differences. The mean longevity attained in this study was less than the one cited by El-Hag and Zaitoon (1996) who

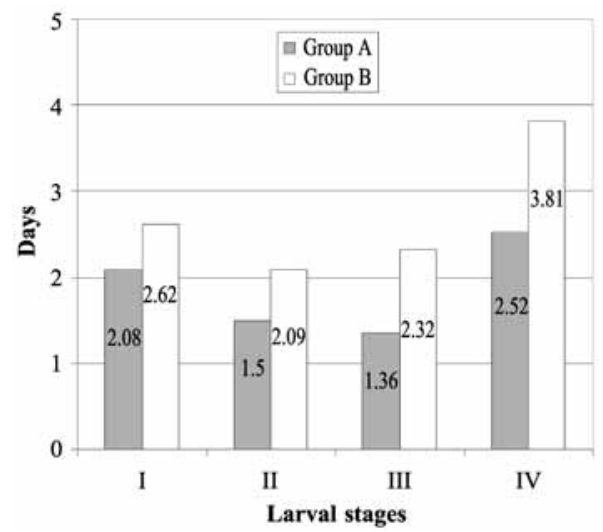

Figure 3. Duration (days) of the Hippodamia variegata larval stages under artificial breeding conditions. Group A (December) and Group B (January). fed $H$. variegata with B. brassicae and $R$. padi at $25 \pm 2{ }^{\circ} \mathrm{C}$, and observed a mean adult longevity of 70 days.

\section{Natural enemies of $H$. variegata}

The only species of parasitoid found was Dinocampus coccinellae (Schrank) (Hymenoptera: Braconidae) which affected $30 \%$ of the adults collected in the field according to the breeding mortality register of adults collected in alfalfa.

\section{CONCLUSIONS}

The life cycle of $H$. variegate had a mean duration of $17.3 \pm 0.93$ days, with a mean adult longevity of $53.27 \pm$ 10.82 days. Both measurements did not differ statistically when comparing both groups grupos $(\mathrm{P}=0.377$ and $\mathrm{P}=$ 0.485 for the life cycle and longevity, respectively).

It was determined that $H$. variegata required 190.32 \pm 10.2 degree-days to complete a generation, signifying that under the existing environmental conditions in the central plain of La Araucanía Region, this coccinellid can complete up to four generations per season. However, based on the population fluctuation and relative abundance records, it is concluded that this insect is not abundant as a natural control agent in the zone under study.

The population fluctuation of coccinellid was markedly seasonal with a complete absence of specimens during the winter and progressive population increases up to an annual maximum at the beginning and middle of the summer, during the first and second year, respectively. The relative abundance of this insect in alfalfa was $0.17 \pm 0.18$ specimens $\mathrm{m}^{-2}$ for adults and $0.16 \pm 0.25$ specimens $\mathrm{m}^{-2}$ for larvae.

The presence of the hymenoptera parasitoid Dinocampus coccinellae (Schrank) (Hymenoptera: Braconidae) was confirmed in $30 \%$ of the adults collected in the alfalfa crop. 


\section{ACKNOWLEDGEMENTS}

We acknowledge the research projects 9713 and 120303 of the Dirección de Investigación of the Universidad de La Frontera DIDUFRO.

\section{RESUMEN}

Ciclo vital, estacional y fluctuación poblacional de Hippodamia variegata (Goeze) (Coleoptera: Coccinellidae), en el llano central de La Araucanía, Chile. El presente estudio fue llevado a cabo en un cultivo de alfalfa ubicado en el llano central de la Región de La Araucanía, Chile, y en el laboratorio de Entomología Aplicada de la Facultad de Ciencias Agropecuarias y Forestales de la Universidad de La Frontera, donde se determinaron aspectos de la biología de Hippodamia variegata (Goeze) (Coleoptera: Coccinellidae), específicamente en relación a su ciclo vital, estacional y fluctuación poblacional. Se determinó que en condiciones de laboratorio este coccinélido requiere 190,32 \pm 10,2 grados días para completar una generación, antecedente que sumado a los muestreos de campo permitió estimar que $H$. variegata completa cuatro generaciones por temporada en el cultivo de alfalfa (Medicago sativa L.).

Palabras clave: ciclo vital, ciclo estacional, fluctuación poblacional, Hippodamia variegata, Medicago sativa.

\section{LITERATURE CITED}

Aalbersberg, Y., P. Hewitt, and M. van der Westhuizen. 1988. Natural enemies and their impact on Diuraphis noxia (Mordvilko) (Hemiptera: Aphididae) populations. Bull. Entomol. Res. 78:111-120.

Aguilera, A., C. Klein, and R. Rebolledo. 2005. Distribution and abundance of Coccinellini (Coleoptera: Coccinellidae) in Temuco, Región de La Araucanía, Chile. Idesia 23:51-57.

Aguilera, A., R. Rebolledo, y C. Klein. 2006. Coccinélidos (Coleoptera) depredadores de Myzocallis corily (Goeze), (Hemiptera: Aphididae) en La Araucanía, Chile. Idesia 24:13-16.

Apablaza, J., y T. Stevenson. 1995. Fluctuaciones poblacionales de áfidos y otros artrópodos en el follaje de alfalfa cultivada en la Región Metropolitana. Cien. Inv. Agr. 22:115-121.

Arias, E. 2000. Coleópteros de Chile. 209 p. Fototeknika, Santiago, Chile.
Badawy, A. 1969. The biology of Adonia variegata Goeze and its role in combatting berseem aphids in the Sudan) (Coleoptera: Coccinellidae). Bull. Soc. Entomol. d'Egypte 52:391-396.

Burgio, G., R. Ferrari, L. Boriani, M. Pozzati, and J. Van Lenteren. 2006. The role of ecological infrastructures on Coccinellidae (Coleoptera) and other predators in weedy field margins within northern Italy agroecosystems. Bull. Insectol. 59:59-67.

Butani, D. 1972. Some new insects associated with cotton (Gossypium hirsutum) in northern hirsutum arboreum region. Indian J. Entomol. 33:227-228.

Dinelli, D. 1999. MIP orientado a un cuidado sanitario holístico de pasto para césped: perspectiva de quién lo practica. Available at http://ipmworld.umn.edu/ cancelado/Spchapters/dinelliSP.htm (Accessed 23 September 2004).

El-Hag, E., and A. Zaitoon. 1996. Biological parameters for four coccinellid species in Central Saudi Arabia. Biol. Control 7:316-319.

Ferran, A., G. Iperti, L. Lapchin, and J. Rabasse. 1989. Flight orientation of Adonia variegata Goeze, Coccinella septempunctata L. and Propylea quatuordecimpunctata L. (Col. Coccinellidae) to a field of wheat in spring. Agronomie 9:903-909.

Franzmann, B. 2002. Hippodamia variegata (Goeze) (Coleoptera: Coccinellidae), a predacious ladybird new in Australia. Aust. J. Entomol. 41(4):375-377.

García, V., and J. Ribeiro. 1983. Olfactometry as a selection method for aphidophagous coccinellids. Arquipel. Ser. Cienc. Nat. 4:31-41.

González, G. 2006. Los Coccinellidae de Chile. Available at http://coccinellidae.cl/inicio.php (Accessed 12 July 2006).

Grez, A., and E. Prado. 2000. Effect of plant patch shape and surrounding vegetation on the dynamics of predatory Coccinellids and their prey, the cabbage aphid Brevicoryne brassicae. Environ. Entomol. 29:1244-1250.

Grez, A., and P. Villagrán. 2000. Effect of structural heterogeneity of a laboratory arena on the movement patterns of adult Eriopis connexa and Hippodamia variegata (Coleoptera: Coccinellidae). Eur. J. Entomol. 98:563-566.

Grigorov, S. 1977. Biological peculiarities of some ladybird beetle species (Coleoptera: Coccinellidae). Rasteniev'dni Nauki 14:133-142.

Hagen, K. 1962. Biology and ecology of predaceous Coccinellidae. Annu. Rev. Entomol. 7:289-326.

Haile, A., and T. Megenasa. 1987. Survey of aphids on barley in parts of Shewa, Welo and Tigrai, Ethiopia. Ethiopian J. Agric. Sci. 9:39-53. 
Hameed, S., V. Sud, and N. Kashyap. 1977. Adonia variegata Goeze (Coccinellidae: Coleoptera), an important predator of the Indian grain aphid, Macrosiphum (Sitobion) miscanthi Tak. Indian J. Entomol. 37:209-210.

Hodek, I. 1967. Bionomics and ecology of predaceous Coccinellidae. Annu. Rev. Entomol. 37(2):209-210.

Honek, A. 1985. Habitat preference of aphidophagous coccinellids (Coleoptera). Entomophaga 30(3):253-264.

Khan, I., S. Din, S. Khan, and M. Ather. 2007. Survey of predatory Coccinellids (Coleoptera: Coccinellidae) in the Chitral District, Pakistan. J. Insect Sci. 7:1-6.

Kim, C., Y. Noh, and J. Kim. 1968. Study on the natural enemies pepper in Korea attacking fall webworn, Hyphantria cunea Drury. Entomol. Res. Bull. Korea 4:17-36.

Kontodimas, D., and G. Stathas. 2005. Phenology, fecundity and life table parameters of the predator Hippodamia variegata reared on Dysaphis crataegi. BioControl 50:223-233.

Krafsur, E.S., J.J. Obrycki, and P. Nariboli. 1996. Gene flow in colonizing Hippodamia variegata ladybird beetle populations. J. Hered. 87(1):41-47.

Linskii, V. 1984. The changeable ladybird. Zashchita Rastenii (Moskva) 4:56.

Metcalf, C., y W. Luckman. 1990. Introducción al manejo de plagas de insectos. 710 p. Editorial Limusa, México.

Mitchels, G., and A. Bateman. 1986. Larval biology of two imported predators of the greenbug, Hippodamia variegata (Goeze) and Adalia flavomaculata Degeer, under constant temperatures. Southwest. Entomol. 11:23-30.

Mitchels, G., and R. Flanders. 1992. Larval development, aphid consumption and oviposition for five imported coccinellids at constant temperature on Russian wheat aphids and greenbugs. Southwest. Entomol. 17:233-243.

Natskova, V. 1973. The influence of parasitic and predacious insect on the rose aphid Macrosiphum rosae L. (Homoptera, Aphididae). Gradinarska i Lozarska Nauka 10:115-122.

Nicoli, G., L. Limonta, and M. Pozzati. 1995. The role of hedges in the agroecosystem. I. Initial studies on the coccinellid predators of aphids. Informatore Fitopatologico 45:58-64.

Nieto, J.M., y M. Mier. 1985. Tratado de entomología. 599 p. Ediciones Omega, Barcelona, España.

Obrycki, J. 1998. Predaceous Coccinellidae in biological control. Annu. Rev. Entomol. 43:295-321.

Obrycki, J., and C. Orr. 1990. Suitability of three prey species for Neartic populations of Coccinella septempunctata, Hippodamia variegata, and Propylea quatuordecimpunctata (Coleoptera: Coccinellidae). J. Econ. Entomol. 83:1292-1297.
Pekin, V. 1996. Morphophysiological adaptations of Coccinellidae (Coleoptera) to arid conditions. Russian J. Ecol. 27:274-277.

Plaza, E. 1987. Clave para la identificación de los géneros y catálogo de las especies españolas peninsulares y baleáricas de Coccinellidae (Coleoptera). Graellsia 46:19-45.

Pruszynski, S., and J. Lipa. 1971. The occurrence of predatory Coccinellidae on alfalfa crops. Ekologia Polska 19:365-386.

Radwan, Z., and G. Lovei. 1982. Distribution and bionomics of ladybird beetle (Col. Coccinellidae) living in an apple orchard near Budapest, Hungary. Z. Angew. Entomol. 94(2):169-175.

Rebolledo, R., R. Palma, C. Klein, y A. Aguilera. 2007. Coccinellini (Col. Coccinellidae) presentes en diferentes estratos vegetales en la IX Región de La Araucanía (Chile). Idesia 25:63-71.

Rojas, S. 1980a. Introducción de insectos entomófagos para el control biológico de los pulgones del trigo Methopolophium dirhodum (Walker) y Sitobion avenae (Frabricius). Simiente 50:33-39.

Rojas, S. 1980b. Establecimiento de tres especies de insectos entomófagos introducidos. Simiente 50:106-108.

Saharaoui, L., and J. Gourreau. 1998. Coccinellids of Algeria: preliminary inventory and food range (Coleoptera: Coccinellidae). Bull. Soc. Entomol. Fr. 103:213-224.

Shing, D., and H. Shing. 1994. Predatory potentiality of coccinellids, Coccinella septempunctata Linn. and Hippodamia variegata (Goeze) over mustard aphid, Lipaphis erysimi (Kalt.). Crop Res. Hisar (India) 7:120-124.

Visauta, R. 1997. Análisis estadístico con SPSS para Windows, Estadística básica. 304 p. Editorial McGraw-Hill/Interamericana, Madrid, España.

Visauta, R. 1998. Análisis estadístico con SPSS para Windows, Estadística básica. Vol. II. 358 p. Editorial McGraw-Hill/Interamericana, Madrid, España.

Wu, Q. 1986. Investigation on the fluctuations of dominant natural enemy population in different cotton habitats and integrated application with biological agents to control cotton pest. Natural Enemies of Insects 8:2934.

Zúñiga, E. 1985. Ochenta años de control biológico en Chile. Revisión histórica y evaluación de los proyectos desarrollados. Agric. Téc. (Chile) 45:175-183.

Zúñiga, E., H. Suzuki, y R. Vargas.1986. Control biológico de los áfidos (Homoptera: Aphididae) de los cereales en Chile. III. Multiplicación y producción masiva de depredadores y parasitoides introducidos. Agric. Téc. (Chile) 46:489-494. 
Petit, A., J. Berkaloff, and J. Temple. 1986. Multiple transformation of plant cells by Agrobacterium may be responsible for the complex organization of hairy root T-DNA. Mol. Gen. Genetic 202:388-393.

Preece, J.E., J.W van Sambeek, C.A. Huetteman, and G.R. Gaffney. 1989. In vitro studies with walnut (Juglans) species. p. 159-180. In Phelps, J.E. (ed.) The continuing quest for quality. Proceedings of $4^{\text {th }}$ Black Walnut Symposium, Carbondale, Illinois. Walnut Council, Indianapolis, Indiana, USA.

Quoirin, M., et P. Lepoivre. 1977. Etudes de milieux adaptés aux cultures in vitro de Prunus. Acta Hortic. 78:437-442.

Ríos, D., M. Sánchez-Olate, M. Gea, y R. Rodríguez. 2002. Nuevos sistemas experimentales para el estudio de la rizogénesis en nogal. Agrociencia 17:221-228.

Ripetti, V., C. Kevers, and Th. Gaspar. 1994. Two successive media for the rooting of walnut shoots in vitro. Changes in peroxidase activity and in ethylene production. Adv. Hort. Sci. 8:29-32.

Rodríguez, R., M. Fernández, J. Pacheco, y M. Cañal. 2005. Envejecimiento vegetal, una barrera a la propagación. Alternativas. p. 29-49. In SánchezOlate, M., y D. Ríos (eds.). Biotecnología vegetal en especies leñosas de interés forestal. Universidad de Concepción, Concepción, Chile.

Sánchez-Olate, M. 1997. Bases macromorfológicas y moleculares de la micropropagación de nogal (Juglans regia L. cv. Serr). 203 p. Tesis Doctoral. Universidad de Oviedo, Oviedo, España.

Sánchez-Olate, M., D.G. Ríos, M.A. Gea, R.E. Rodríguez, and M.A. Revilla. 1997. Parameters affecting the in vitro growth and rooting of Juglans regia L. Acta Hort. (ISHS) 442:235-240.
Sánchez-Olate, M., D. Ríos, M.A. Revilla. y R. Rodríguez. 2002. Participación de poliaminas endógenas en el desarrollo de injertos y brotes epicórmicos de nogal. Agrociencia 17:215-219.

Sánchez-Olate, M., D. Ríos, R. Rodríguez, M. Materán, y G. Pereira. 2004. Duración del efecto revigorizante de podas severas de plantas adultas de avellano europeo (Corylus avellana L.) cv. Negretta sobre el cultivo in vitro. Agric. Téc. (Chile) 64:338-346.

Sierra, C. 2002. Propagación vegetativa de Castanea sativa Mill. y Juglans regia L. a través de estacas. Tesis Ingeniero Forestal. Universidad de Concepción, Facultad de Ciencias Forestales, Concepción, Chile.

Steel, R.G.D., y J.H. Torrie. 1985. Bioestadística: Principios y procedimientos $2^{\text {a }}$ ed. McGraw-Hill, Bogotá, Colombia.

Strobel, G.A., and A. Nachmias. 1988. Agrobacterium rhizogenes: a root inducing bacterium. p. 284-288. In Davis, T.D., Haissig, B.E., and N. Sankhla (eds.) Adventitious root formation in cuttings. Dioscorides Press, Portland, Oregon, USA.

Tepfer, D. 1984. Transformation of several species of higher plants by Agrobacterium rhizogenes: sexual transmission of the transformed genotype and phenotype. Cell 37:959-967.

Vahdati, K., J. McKenna, A. Dandekar, C. Leslie, S. Uratsu, W. Hackett, P. Negri, and G. McGranahan. 2002. Rooting and other characteristics of a transgenic walnut hybrid (Juglans hindsii x J. regia) rootstock Expressing rolABC. J. Amer. Soc. Hort. Sci. 27:724728. 


\title{
LIFE, SEASONAL CYCLES, AND POPULATION FLUCTUATION OF Hippodamia variegata (GOEZE) (COLEOPTERA: COCCINELLIDAE), IN THE CENTRAL PLAIN OF LA ARAUCANÍA REGION, CHILE
}

\author{
Ramón Rebolledo ${ }^{*}$, Johnny Sheriff ${ }^{1}$, Leonardo Parra1, and Alfonso Aguilera ${ }^{1}$
}

\begin{abstract}
This study was performed on an alfalfa crop located on the central plain of La Araucanía Region, Chile and in the Laboratorio de Entomología Aplicada de la Facultad de Ciencias Agropecuarias y Forestales at the Universidad de La Frontera. Certain aspects of the biology of Hippodamia variegata (Goeze) (Coleoptera: Coccinellidae) were determined, more specifically in relation to its life cycle, seasonality, and population fluctuation. It was established that this coccinellid requires $190.32 \pm 10.2$ degree-days to complete a generation under laboratory conditions. This information along with the field samplings made it possible to calculate that $H$. variegata completes four generations per season in the alfalfa crop (Medicago sativa L.).
\end{abstract}

Key words: life cycle, seasonal cycle, population fluctuation, Hippodamia variegata, Medicago sativa.

\section{INTRODUCTION}

Hippodamia variegata (Goeze) is an active aphid predator used in the biological control of plant lice in cereals and oil plants in diverse countries (Linskii, 1984; Zúñiga, 1985; Zúñiga et al., 1986; Obrycki and Orr, 1990; Shing and Shing, 1994; El-Hag and Zaitoon, 1996; Obrycki, 1998; González, 2006). Its origin is Palearctic, with a cosmopolitan distribution (Krafsur et al., 1996; Franzmann, 2002), and is found in Asia (Kim et al., 1968; Butani, 1972; Hameed et al., 1977; Wu, 1986), Africa (Badawy, 1969; Haile and Megenasa, 1987; Aalbersberg et al., 1988; Saharaoui and Gourreau, 1998), and Europe (Pruszynski and Lipa, 1971; Natskova, 1973; Radwan and Lovei, 1982; García and Ribeiro, 1983; Plaza, 1987; Ferran et al., 1989; Nicoli et al., 1995; Pekín, 1996; Burgio et al., 2006). It was first introduced in Chile in 1967 as a result of the manifestation of the pale green louse of Metopolophium dirhodum (Walk.) gramineae and the dark ear louse of Sitobion avenae (Fabricius) (Rojas, 1980 a; 1980b). H. variegata is found in Chile from the Arica and Parinacota Region to the Los Lagos Region (González, 2006). According to Aguilera et al. (2005, 2006) and Rebolledo et al. (2007), its occurrence is notable in La Araucanía Region and is very abundant. Grigorov

${ }^{1}$ Universidad de La Frontera, Facultad de Ciencias Agropecuarias y Forestales, Casilla 54-D, Temuco, Chile.

*Corresponding author (ramonr@ufro.cl).

Received: 21 December 2007.

Accepted: 25 May 2008.
(1977), Honek (1985) and Rebolledo et al. (2007) state that $H$. variegata prefers herbaceous plants. Nevertheless, Rebolledo et al. (2007) point out that it is possible to find this species in shrubby and arboreous plants.

Hagen (1962) affirms that coccinellids determine their conduct through four fundamental actions: voltinism, dormancy or diapause, migrations, and formation of aggregates (Hagen, 1962; Hodek, 1967). Voltinism (the number of generations per year) varies according to latitude. Hagen (1962) recognizes four types of voltinism: I = one generation; II = two generations; III or IV = three or more generations; IA = one generation whose adults migrate to hibernate.

Diapause is intimately related to voltinism given that the latter is a consequence of the former (Nieto y Mier, 1985). Hagen (1962) states that there are three types of dormancy depending on the season: (1) hibernation (Types with voltinism I, II, and III), (2) estivation and hibernation (Type IIA), (3) estivo-hibernation (Type IA). With regards to the formation of aggregates, this same author points out that this is perhaps the most fascinating phenomenon of the coccinellids. The majority of them have an instinctive tendency to hibernate socially, just as it occurs with established tribes such as Hippodamini and Anisoctictini. H. variegata prefer an aggregation site on mountain tops or close to these (Khan et al., 2007). With respect to the migration phenomenon, Hagen (1962) indicates that the long migratory flights are related to the search for dormancy sites, and that these are associated at the same time with the formation of aggregates. This coccinellid has been studied in the country as regards 
distribution (Arias, 2000) and predatory activity (Grez and Prado, 2000; Grez andVillagrán, 2000). However, there are no data about voltinism and population fluctuation. In La Araucanía Region, $H$. variegata is an abundant species and especially in alfalfa (Medicago sativa L.) (Rebolledo et al., 2007).

In order to complement the previous studies and increase knowledge about its behavior in La Araucanía, it was proposed to determine its life and seasonal (voltinism) cycles, fluctuation, relative abundance, and its possible natural entomophagous enemies.

\section{MATERIALS AND METHODS}

\section{Field work}

Two seasons (1999-2000 and 2000-2001) were required to determine fluctuation and population density of $H$. variegate (in an alfalfa field located in the former Estación Experimental Maipo belonging to the Facultad de Ciencias Agropecuarias y Forestales of the Universidad de La Frontera, located in the urban radius of the city of Temuco (38 $44^{\prime}$ S, $72^{\circ} 35^{\prime}$ W, 100 m.a.s.l.). Breeding of $H$. variegata adults was done with the alfalfa greenbug Acyrthosiphon pisum (Harris).

$H$. variegata adults were periodically collected with entomological nets during October and March in an alfalfa field. Adults were collected in December and were placed in plastic containers measuring $6.5 \mathrm{~cm}$ in height, $5.0 \mathrm{~cm}$ diameter, and covered with tulle.

To determine the relative abundance and population fluctuation between October 1999 and March 2001, the alfalfa field was visited 46 times. The sampling was carried out periodically every $10 \pm 1$ day during the spring, summer, and autumn months, and every $20 \pm 1$ day during the winter months. Each sample consisted in passing 20 times with a standard $30 \mathrm{~cm}$ diameter entomological net over the foliage in a $180^{\circ}$ range, at a regular pace following the methodology proposed by Metcalf and Luckman (1990) and Apablaza and Stevenson (1995). The sampled area was divided into four 1 ha $^{-1}$ quadrants, numbered clockwise to facilitate sampling. Three samples were taken in each quadrant by leaving a minimum distance of $25 \mathrm{~m}$ between each replicate, checking, and registering the collected material. To determine the number of individuals per $\mathrm{m}^{2}$, considering that the width was the amplitude that the net covered in a $180^{\circ}$ horizontal movement and the length as the distance covered in the sample.

\section{Laboratory work}

H. variegata adults collected in the field were moved to a germination chamber (Archiclima, Temuco, Chile) with controlled humidity conditions ( $70 \pm 8 \%$ ), temperature (21 $\pm 2{ }^{\circ} \mathrm{C}$ ), and photoperiod (16:8 light:darkness) to observe their behavior. Following copulation, males and females were separated. The confined adults were controlled daily to register and eliminate the parasitoids from the breeding.

The laboratory study of the $H$. variegate life cycle was initiated by obtaining eggs from the adults collected in December. These were deposited on Petri dishes and were incubated in the germination chamber in the abovementioned conditions. When the eggs hatched, 80 larvae were separated, individually placed on numbered plastic dishes, and named initial breeding or group A. From this initial breeding, 57 adults were obtained from which 28 couples were formed at the beginning of January and separated into two groups of 14 . A subgroup called AI was made up of 14 females that were permanently maintained with a male, and the second subgroup (AII) was formed by the remaining couples, but maintained with the male only during $48 \mathrm{~h}$. Ten eggs were taken from each female which were bred in isolation in order to determine the influence of the male in the oviposition.

To measure the duration of the life cycle during the month of January, 48 individualized larvae were used as group B and obtained from the 10 isolated eggs of each couple. A new group of 40 larvae were chosen randomly from a single emergence date to determine the growth of each larval stage. The measurements were taken and registered every $24 \mathrm{~h}$. Seven larvae from each larval stage were placed in glass containers with $75 \%$ alcohol to subsequently measure the length and width of each one with the help of graph paper. The widest sector of the thorax was used to measure the width, and the length was considered from the top of the head to where the abdomen ends. Furthermore, the width and length of seven pupas, also chosen randomly from groups A and B, were measured

From the individuals used previously, 22 adults were taken to determine their longevity (50\% males and 50\% females), were fed daily with $A$. pisum and observed until the moment of their natural death.

The summation of degree-days required for a generation was established to determine the seasonal cycle of $H$. variegate. The formula proposed by Dinelli (1999) was used to calculate this summation. This value was contrasted with the results obtained during the months of field study allowing to determine the degree-days required for the activation of the adults following their hibernation, and the number of generations that theoretically occurred in the study zone.

The reason to use two groups (A and B) was the fact that these coccinellids were collected in different periods, and hence separate statistical analyses were done. An experimental randomized complete block design was used where each individual corresponded to one replicate. 
The data of the specimens that completed the life cycle (groups A and B) were compared with variance analysis. Then these results were analyzed using appropriate tests to compare the means of two independent samples, whether parametric (t-Student) or nonparametric (U - MannWhitney) (Visauta, 1997; 1998).

\section{RESULTS AND DISCUSSION}

\section{Population fluctuation of $\boldsymbol{H}$. variegata}

The first adults were examined during October and their number varied between seasons for what seemed to be a clear dependence on the particular yearly environmental conditions. They were completely absent during the winter which accounts for their natural behavior to enter diapause or hibernation. The fluctuation during the period under study showed two annual maxima, one on 10 December 1999 (15 specimens) and the second on 6 February 2001 (13 specimens) (Figure 1).

A noticeable increase in population levels occurred at the beginning of autumn, possibly related with the generation that spent the winter in diapause, results which coincided with those obtained by Apablaza and Stevenson (1995) who pointed out that the annual population maxima for coccinellids in alfalfa in the Metropolitana Region took place at the end of March.

\section{Relative abundance of $\boldsymbol{H}$. variegata}

The relative abundance of this insect was $0.17 \pm$ 0.18 adult specimens $\mathrm{m}^{-2}$ with a variation of 0 to 0.68 individuals $\mathrm{m}^{-2}$. The larvae showed a mean relative abundance of $0.16 \pm 0.25$ specimens $\mathrm{m}^{-2}$ fluctuating between 0 and 1 individuals $\mathrm{m}^{-2}$.

\section{Voltinism of $\boldsymbol{H}$. variegata}

$H$. variegata required $190.32 \pm 10.2$ degree-days to complete a generation considering $10{ }^{\circ} \mathrm{C}$ as the threshold temperature, the one recommended for the majority of coccinellids. During the first sampling season (spring 1999-summer 2000), it was difficult to estimate the number of generations due to a generational overlap since larvae and adults were found in the crop at the beginning of the measurements. Taking into account only the degree-days accumulated during October and November, it was estimated that the necessary degrees would be on 28 November to complete a first generation. The second generation would be obtained at the end of December, a third on the first days of February, and a fourth and final generation during the first week of March, going through the winter in diapause as an adult.

In the second season (spring 2000-summer 2001), the exact date was registered when adults first appeared coming out of their diapause. It was estimated that soon after the appearance of posthibernational adults, at the end of September, the first generation in the crop was completed around 10 December, obtaining the second generation during the second half of January, and the third generation at the end of the first half of February (Figure 2).

These results differed from those informed by Kontodimas and Stathas (2005) who indicate that a study carried out in Greece using $H$. variegate as a food source for D. crataegi, completed a total of seven generations between April and November.

$H$. variegata completed four generations during this study under the environmental conditions of the central plain of La Araucanía Region, the first of them with a longer duration with two to two and one half months, whereas

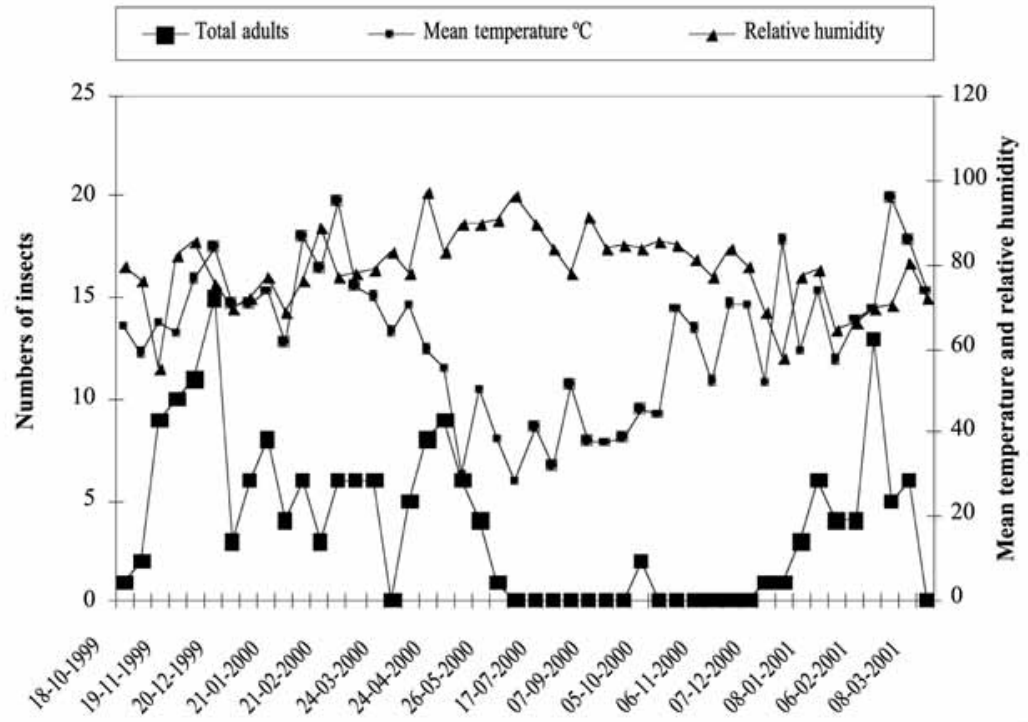

Figure 1. Population fluctuation of Hippodamia variegata adults in the central plain of La Araucanía Region. 


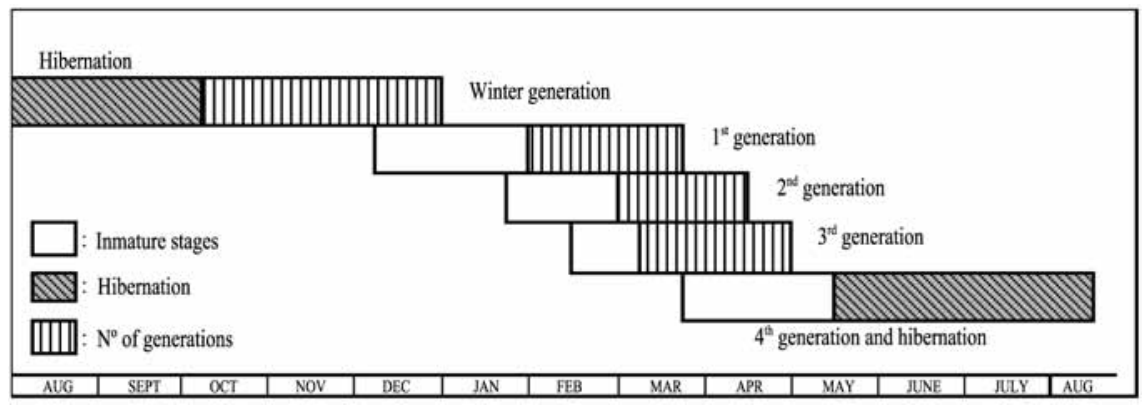

Figure 2. Diagram of Hippodamia variegata voltinism in the central plain of La Araucanía Region (2000-2001).

the rest only took one month that is, they showed a type III voltinism in accordance with that proposed by Hagen (1962). The fact that there was a high overlap between one generation and another is emphasized, fact essentially due to the extensive duration of the adult stage in comparison to the rest of the stages of the life cycle. The polivoltinism observed concurred with Hagen (1962) who pointed out that the environmental conditions are what determine the number of possible generations for coccinellids.

\section{Life cycle of $H$. variegata}

$H$. variegata showed a life cycle of $17.3 \pm 0.93$ days varying in a range of 16 to 21 days. The pupa stage showed the longest duration with $32 \%$ of the life cycle total time, followed by the egg stage and fourth larval stage with $17 \%$ each. There is a discrepancy between this result and the one reported by Badawy (1969) who indicates a mean duration of 10.7 days for the life cycle. Breeding temperature would be a fundamental factor in the rate of preimaginal development according to Hagen (1962), Mitchels and Bateman (1986) who mention a duration of 15.1 days at $25^{\circ} \mathrm{C}$ for the $H$. variegata life cycle, wheras the life cycle decreased to 7.8 days at $30^{\circ} \mathrm{C}$. The difference between this study and those stated by Hagen (1962) and Badawy (1969) can be attributed to the use of other breeding temperatures.

Oviposition, hatching, and incubation period of $\boldsymbol{H}$. variegate eggs

Mating occurred between 2 and 5 days of life, registering the first ovipositions two days later, which is in accordance with that pointed out by Hodek (1967) and Badawy (1969). The oviposition and hatching of the $H$. variegata eggs are shown in Table 1 . With respect to incubation time, it was three days for both groups.

The mean monthly oviposition of $H$. variegata was 223 \pm 103.9 eggs and its frequency reached $4.37 \pm 5.82$ days, a contrast with that reported by Kontodimas and Stathas (2005) who obtained a mean of 956.6 eggs in one breeding of $H$. variegata carried out in Greece. However, that study used Dysaphis crataegi (Kaltenbach) as a food source at a temperature of $25^{\circ} \mathrm{C}$, while the temperature in the present research was $21^{\circ} \mathrm{C}$ and the food was Acyrthosiphon pisum (Harris). The mean of eggs per day of oviposition in the AI subgroup reached $17.58 \pm 6.73$, whereas the groups of eggs attained a mean of $1.59 \pm 0.41$ per day of oviposition. At the same time, subgroup AII showed values similar to those in the previous subgroup with a mean oviposition of $18.73 \pm 6.33$ eggs per day of oviposition, a mean of 1.61 \pm 0.27 groups per day of oviposition. Differences were not significant between the two subgroups.

\section{Duration of $\boldsymbol{H}$. variegata larval stages}

In group A, made up of larvae emerged from the AI and AII subgroups, the mean duration of their development was $7.98 \pm 0.73$, days with a range that fluctuated between 7 and 10 days, with the first and fourth stages having the longest duration with 26 and 32\%, respectively, considering the total development of this stage of the insect, and coinciding with that reported by Badawy (1969). However, it must be pointed out that this author used the aphid Aphis gossypii Glover as food for the $H$. variegata larvae.

The larval stage in group B developed in $10.67 \pm 1.62$ days with a range that varied between 9 and 15 days, coinciding with that found by Mitchels and Flanders (1992), El-Hag and Zaitoon (1996) who determined a mean duration of the larval stage of 11 days using Diuraphis noxia (Mordvilko) and Brevicoryne brassicae (L.) + Rhopalosiphum padi (L.) as food, respectively. This would indicate that the aphid species used did not determine a difference in the duration of the larval stage. The difference in the duration of the larval period between groups A and B would be due to the capture period of the adults (December for group A and January for group B) in which breeding was initiated (Figure 3). The results of the growth of the randomly chosen larval stages are shown in Table 2.

\section{Duration of $\boldsymbol{H}$. variegata pupa stage}

The duration of the pupa stage showed significant differences depending on its origin as group $\mathrm{A}$ or $\mathrm{B}$. 
Table 1. Oviposition and egg hatching percentage of Hippodamia variegata.

\begin{tabular}{lcccc}
\hline Subgroups & $\begin{array}{c}\text { Eggs } \\
\text { day }^{\mathbf{1}}\end{array}$ & $\begin{array}{c}\text { Hatching } \\
\text { mean (\%) }\end{array}$ & $\begin{array}{c}\text { Groups of } \\
\text { eggs day }^{-1}\end{array}$ & $\begin{array}{c}\text { variation } \\
\text { (\%) }\end{array}$ \\
\hline $\mathrm{AI}^{1}$ & $17.58 \pm 6.73$ & $87.81 \pm 5.76$ & $1.59 \pm 0.41$ & $80-100$ \\
$\mathrm{AII}^{2}$ & $18.73 \pm 6.33$ & $81.96 \pm 7.27$ & $1.61 \pm 0.27$ & $72-100$ \\
\hline
\end{tabular}

${ }^{1}$ Permanent couple. ${ }^{2}$ Couple with male only $48 \mathrm{~h}$.

Table 2. Larval instar size of Hippodamia variegata.

\begin{tabular}{lcccc}
\hline State & Mean length $(\mathbf{m m})$ & Range & Mean width $(\mathbf{m m})$ & Range \\
\hline 1 & $1.64 \pm 0.56$ & $1-1.15$ & 0.5 & 0 \\
2 & $2.28 \pm 0.27$ & $2-2.25$ & 1 & 0 \\
3 & $4.07 \pm 0.45$ & $3.5-4.5$ & $2.28 \pm 0.27$ & $2-2.25$ \\
4 & $6.57 \pm 0.44$ & $6-7$ & 2 & 2.25 \\
\hline
\end{tabular}

Group A had a mean duration of $6.27 \pm 0.45$ days with a range of 6 to 7 days, while group B reached a mean of $4.28 \pm 0.61$ days and a variation between 3 and 5 days. Badawy (1969) points out a smaller mean duration value of 2.61 days than the one found in this study, difference based on a higher breeding temperature. The mean size of the randomly chosen pupas was a length of $4.57 \pm 0.45$ mm varying between 4 and $5 \mathrm{~mm}$, and an observed width of $2.57 \pm 0.45$ with a range of 2 to $3 \mathrm{~mm}$.

\section{Longevity of $\boldsymbol{H}$. variegata}

The longevity mean of the adults in both groups was $53.27 \pm 11.93$ days. The females showed longevity of $55.09 \pm 10.85$ days and the males $51.45 \pm 13.03$ days. However, these numbers did not show any significant differences. The mean longevity attained in this study was less than the one cited by El-Hag and Zaitoon (1996) who

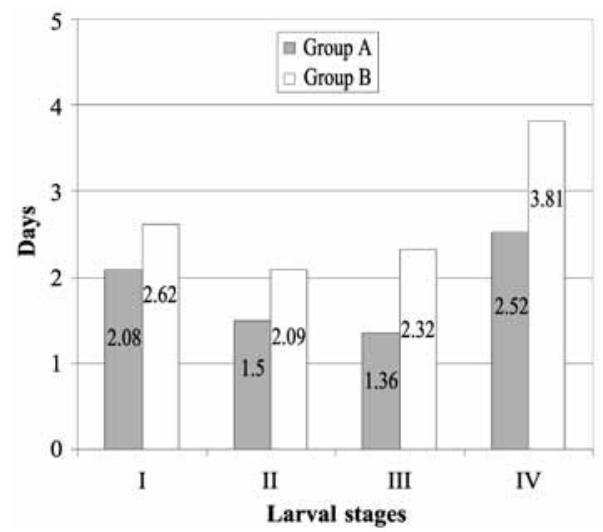

Figure 3. Duration (days) of the Hippodamia variegata larval stages under artificial breeding conditions. Group A (December) and Group B (January). fed $H$. variegata with B. brassicae and $R$. padi at $25 \pm 2{ }^{\circ} \mathrm{C}$, and observed a mean adult longevity of 70 days.

\section{Natural enemies of $H$. variegata}

The only species of parasitoid found was Dinocampus coccinellae (Schrank) (Hymenoptera: Braconidae) which affected $30 \%$ of the adults collected in the field according to the breeding mortality register of adults collected in alfalfa.

\section{CONCLUSIONS}

The life cycle of $H$. variegate had a mean duration of $17.3 \pm 0.93$ days, with a mean adult longevity of $53.27 \pm$ 10.82 days. Both measurements did not differ statistically when comparing both groups grupos $(\mathrm{P}=0.377$ and $\mathrm{P}=$ 0.485 for the life cycle and longevity, respectively).

It was determined that $H$. variegata required 190.32 \pm 10.2 degree-days to complete a generation, signifying that under the existing environmental conditions in the central plain of La Araucanía Region, this coccinellid can complete up to four generations per season. However, based on the population fluctuation and relative abundance records, it is concluded that this insect is not abundant as a natural control agent in the zone under study.

The population fluctuation of coccinellid was markedly seasonal with a complete absence of specimens during the winter and progressive population increases up to an annual maximum at the beginning and middle of the summer, during the first and second year, respectively. The relative abundance of this insect in alfalfa was $0.17 \pm 0.18$ specimens $\mathrm{m}^{-2}$ for adults and $0.16 \pm 0.25$ specimens $\mathrm{m}^{-2}$ for larvae.

The presence of the hymenoptera parasitoid Dinocampus coccinellae (Schrank) (Hymenoptera: Braconidae) was confirmed in $30 \%$ of the adults collected in the alfalfa crop. 


\section{ACKNOWLEDGEMENTS}

We acknowledge the research projects 9713 and 120303 of the Dirección de Investigación of the Universidad de La Frontera DIDUFRO.

\section{RESUMEN}

Ciclo vital, estacional y fluctuación poblacional de Hippodamia variegata (Goeze) (Coleoptera: Coccinellidae), en el llano central de La Araucanía, Chile. El presente estudio fue llevado a cabo en un cultivo de alfalfa ubicado en el llano central de la Región de La Araucanía, Chile, y en el laboratorio de Entomología Aplicada de la Facultad de Ciencias Agropecuarias y Forestales de la Universidad de La Frontera, donde se determinaron aspectos de la biología de Hippodamia variegata (Goeze) (Coleoptera: Coccinellidae), específicamente en relación a su ciclo vital, estacional y fluctuación poblacional. Se determinó que en condiciones de laboratorio este coccinélido requiere 190,32 \pm 10,2 grados días para completar una generación, antecedente que sumado a los muestreos de campo permitió estimar que $H$. variegata completa cuatro generaciones por temporada en el cultivo de alfalfa (Medicago sativa L.).

Palabras clave: ciclo vital, ciclo estacional, fluctuación poblacional, Hippodamia variegata, Medicago sativa.

\section{LITERATURE CITED}

Aalbersberg, Y., P. Hewitt, and M. van der Westhuizen. 1988. Natural enemies and their impact on Diuraphis noxia (Mordvilko) (Hemiptera: Aphididae) populations. Bull. Entomol. Res. 78:111-120.

Aguilera, A., C. Klein, and R. Rebolledo. 2005. Distribution and abundance of Coccinellini (Coleoptera: Coccinellidae) in Temuco, Región de La Araucanía, Chile. Idesia 23:51-57.

Aguilera, A., R. Rebolledo, y C. Klein. 2006. Coccinélidos (Coleoptera) depredadores de Myzocallis corily (Goeze), (Hemiptera: Aphididae) en La Araucanía, Chile. Idesia 24:13-16.

Apablaza, J., y T. Stevenson. 1995. Fluctuaciones poblacionales de áfidos y otros artrópodos en el follaje de alfalfa cultivada en la Región Metropolitana. Cien. Inv. Agr. 22:115-121.

Arias, E. 2000. Coleópteros de Chile. 209 p. Fototeknika, Santiago, Chile.
Badawy, A. 1969. The biology of Adonia variegata Goeze and its role in combatting berseem aphids in the Sudan) (Coleoptera: Coccinellidae). Bull. Soc. Entomol. d'Egypte 52:391-396.

Burgio, G., R. Ferrari, L. Boriani, M. Pozzati, and J. Van Lenteren. 2006. The role of ecological infrastructures on Coccinellidae (Coleoptera) and other predators in weedy field margins within northern Italy agroecosystems. Bull. Insectol. 59:59-67.

Butani, D. 1972. Some new insects associated with cotton (Gossypium hirsutum) in northern hirsutum arboreum region. Indian J. Entomol. 33:227-228.

Dinelli, D. 1999. MIP orientado a un cuidado sanitario holístico de pasto para césped: perspectiva de quién lo practica. Available at http://ipmworld.umn.edu/ cancelado/Spchapters/dinelliSP.htm (Accessed 23 September 2004).

El-Hag, E., and A. Zaitoon. 1996. Biological parameters for four coccinellid species in Central Saudi Arabia. Biol. Control 7:316-319.

Ferran, A., G. Iperti, L. Lapchin, and J. Rabasse. 1989. Flight orientation of Adonia variegata Goeze, Coccinella septempunctata L. and Propylea quatuordecimpunctata L. (Col. Coccinellidae) to a field of wheat in spring. Agronomie 9:903-909.

Franzmann, B. 2002. Hippodamia variegata (Goeze) (Coleoptera: Coccinellidae), a predacious ladybird new in Australia. Aust. J. Entomol. 41(4):375-377.

García, V., and J. Ribeiro. 1983. Olfactometry as a selection method for aphidophagous coccinellids. Arquipel. Ser. Cienc. Nat. 4:31-41.

González, G. 2006. Los Coccinellidae de Chile. Available at http://coccinellidae.cl/inicio.php (Accessed 12 July 2006).

Grez, A., and E. Prado. 2000. Effect of plant patch shape and surrounding vegetation on the dynamics of predatory Coccinellids and their prey, the cabbage aphid Brevicoryne brassicae. Environ. Entomol. 29:1244-1250.

Grez, A., and P. Villagrán. 2000. Effect of structural heterogeneity of a laboratory arena on the movement patterns of adult Eriopis connexa and Hippodamia variegata (Coleoptera: Coccinellidae). Eur. J. Entomol. 98:563-566.

Grigorov, S. 1977. Biological peculiarities of some ladybird beetle species (Coleoptera: Coccinellidae). Rasteniev'dni Nauki 14:133-142.

Hagen, K. 1962. Biology and ecology of predaceous Coccinellidae. Annu. Rev. Entomol. 7:289-326.

Haile, A., and T. Megenasa. 1987. Survey of aphids on barley in parts of Shewa, Welo and Tigrai, Ethiopia. Ethiopian J. Agric. Sci. 9:39-53. 
Hameed, S., V. Sud, and N. Kashyap. 1977. Adonia variegata Goeze (Coccinellidae: Coleoptera), an important predator of the Indian grain aphid, Macrosiphum (Sitobion) miscanthi Tak. Indian J. Entomol. 37:209-210.

Hodek, I. 1967. Bionomics and ecology of predaceous Coccinellidae. Annu. Rev. Entomol. 37(2):209-210.

Honek, A. 1985. Habitat preference of aphidophagous coccinellids (Coleoptera). Entomophaga 30(3):253-264.

Khan, I., S. Din, S. Khan, and M. Ather. 2007. Survey of predatory Coccinellids (Coleoptera: Coccinellidae) in the Chitral District, Pakistan. J. Insect Sci. 7:1-6.

Kim, C., Y. Noh, and J. Kim. 1968. Study on the natural enemies pepper in Korea attacking fall webworn, Hyphantria cunea Drury. Entomol. Res. Bull. Korea 4:17-36.

Kontodimas, D., and G. Stathas. 2005. Phenology, fecundity and life table parameters of the predator Hippodamia variegata reared on Dysaphis crataegi. BioControl 50:223-233.

Krafsur, E.S., J.J. Obrycki, and P. Nariboli. 1996. Gene flow in colonizing Hippodamia variegata ladybird beetle populations. J. Hered. 87(1):41-47.

Linskii, V. 1984. The changeable ladybird. Zashchita Rastenii (Moskva) 4:56.

Metcalf, C., y W. Luckman. 1990. Introducción al manejo de plagas de insectos. 710 p. Editorial Limusa, México.

Mitchels, G., and A. Bateman. 1986. Larval biology of two imported predators of the greenbug, Hippodamia variegata (Goeze) and Adalia flavomaculata Degeer, under constant temperatures. Southwest. Entomol. 11:23-30.

Mitchels, G., and R. Flanders. 1992. Larval development, aphid consumption and oviposition for five imported coccinellids at constant temperature on Russian wheat aphids and greenbugs. Southwest. Entomol. 17:233-243.

Natskova, V. 1973. The influence of parasitic and predacious insect on the rose aphid Macrosiphum rosae L. (Homoptera, Aphididae). Gradinarska i Lozarska Nauka 10:115-122.

Nicoli, G., L. Limonta, and M. Pozzati. 1995. The role of hedges in the agroecosystem. I. Initial studies on the coccinellid predators of aphids. Informatore Fitopatologico 45:58-64.

Nieto, J.M., y M. Mier. 1985. Tratado de entomología. 599 p. Ediciones Omega, Barcelona, España.

Obrycki, J. 1998. Predaceous Coccinellidae in biological control. Annu. Rev. Entomol. 43:295-321.

Obrycki, J., and C. Orr. 1990. Suitability of three prey species for Neartic populations of Coccinella septempunctata, Hippodamia variegata, and Propylea quatuordecimpunctata (Coleoptera: Coccinellidae). J. Econ. Entomol. 83:1292-1297.
Pekin, V. 1996. Morphophysiological adaptations of Coccinellidae (Coleoptera) to arid conditions. Russian J. Ecol. 27:274-277.

Plaza, E. 1987. Clave para la identificación de los géneros y catálogo de las especies españolas peninsulares y baleáricas de Coccinellidae (Coleoptera). Graellsia 46:19-45.

Pruszynski, S., and J. Lipa. 1971. The occurrence of predatory Coccinellidae on alfalfa crops. Ekologia Polska 19:365-386.

Radwan, Z., and G. Lovei. 1982. Distribution and bionomics of ladybird beetle (Col. Coccinellidae) living in an apple orchard near Budapest, Hungary. Z. Angew. Entomol. 94(2):169-175.

Rebolledo, R., R. Palma, C. Klein, y A. Aguilera. 2007. Coccinellini (Col. Coccinellidae) presentes en diferentes estratos vegetales en la IX Región de La Araucanía (Chile). Idesia 25:63-71.

Rojas, S. 1980a. Introducción de insectos entomófagos para el control biológico de los pulgones del trigo Methopolophium dirhodum (Walker) y Sitobion avenae (Frabricius). Simiente 50:33-39.

Rojas, S. 1980b. Establecimiento de tres especies de insectos entomófagos introducidos. Simiente 50:106-108.

Saharaoui, L., and J. Gourreau. 1998. Coccinellids of Algeria: preliminary inventory and food range (Coleoptera: Coccinellidae). Bull. Soc. Entomol. Fr. 103:213-224.

Shing, D., and H. Shing. 1994. Predatory potentiality of coccinellids, Coccinella septempunctata Linn. and Hippodamia variegata (Goeze) over mustard aphid, Lipaphis erysimi (Kalt.). Crop Res. Hisar (India) 7:120-124.

Visauta, R. 1997. Análisis estadístico con SPSS para Windows, Estadística básica. 304 p. Editorial McGraw-Hill/Interamericana, Madrid, España.

Visauta, R. 1998. Análisis estadístico con SPSS para Windows, Estadística básica. Vol. II. 358 p. Editorial McGraw-Hill/Interamericana, Madrid, España.

Wu, Q. 1986. Investigation on the fluctuations of dominant natural enemy population in different cotton habitats and integrated application with biological agents to control cotton pest. Natural Enemies of Insects 8:2934.

Zúñiga, E. 1985. Ochenta años de control biológico en Chile. Revisión histórica y evaluación de los proyectos desarrollados. Agric. Téc. (Chile) 45:175-183.

Zúñiga, E., H. Suzuki, y R. Vargas.1986. Control biológico de los áfidos (Homoptera: Aphididae) de los cereales en Chile. III. Multiplicación y producción masiva de depredadores y parasitoides introducidos. Agric. Téc. (Chile) 46:489-494. 